Florida International University FIU Digital Commons

5-10-1996

\title{
Speciation of uranium and organic compounds on solid matrix studied by supercritical fluid extraction
}

Li Chen

Florida International University

DOI: $10.25148 /$ etd.FI14060169

Follow this and additional works at: https://digitalcommons.fiu.edu/etd

Part of the Chemistry Commons

\section{Recommended Citation}

Chen, Li, "Speciation of uranium and organic compounds on solid matrix studied by supercritical fluid extraction" (1996). FIU Electronic Theses and Dissertations. 2137.

https://digitalcommons.fiu.edu/etd/2137 
FLORIDA INTERNATIONAL UNIVERSITY

Miami, Florida

\title{
SPECIATION OF URANIUM AND ORGANIC COMPOUNDS ON SOLID MATRIX STUDIED BY SUPERCRITICAL FLUID EXTRACTION
}

\begin{abstract}
A thesis submitted in partial satisfaction of the requirements for the degree of
\end{abstract}

\section{MASTER OF SCIENCE IN CHEMISTRY}

by

Li Chen 
To: Dean Arthur W. Herriott

College of Arts and Sciences

This thesis, written by $\mathrm{Li}$ Chen, and entitled Speciation of Uranium and Organic Compounds On Solid Matrices Studied by Supercritical Fluid Extraction, having been approved in respect to style and intellectual content, is referred to you for judgment.

We have read this thesis and recommend that it be approved.

Dr. Yiwei Deng

Professor

Dr. Martin Quirke

Professor

Dr. Rudolf Jaffé,

Co - Major Professor

Dr. Kenneth G. Furton, Major Professor

Date of Defense: May 10, 1996

The thesis of Li Chen is approved.

Dean Arthur W. Herriott

College of Arts and Sciences

Dr. Richard L. Campbell

Dean of Graduate Studies

Florida International University, 1996 
To: Stuart, Peter and Rose 


\section{ACKNOWLEDGMENTS}

Special thanks to my major professor Dr. Furton and my co-major professor Dr. Jaffé for their invaluable and tremendous guidance, support and patience.

Many thanks to my committee member Dr. Deng and Dr. Quirke for their time and input.

Thanks to Dr. Christian Eckardt for kindly providing the Posidonia and Kupferschiefer shale sample.

Many thanks to all graduate students both work in Dr. Furton and Dr. Jaffé's lab with me for all kinds of great support and help.

Special thanks to Florida International University and its Chemistry Department for providing me teaching assistantship.

Special thanks to my employer Noven Pharmaceuticals, Inc, for the tuition assistance program. 


\author{
ABSTRACT OF THE THESIS \\ SPECIATION OF URANIUM AND ORGANIC COMPOUNDS ON \\ SOLID MATRIX STUDIED BY \\ SUPERCRITICAL FLUID EXTRACTION \\ by

\section{CHEN} \\ Florida International University, 1996 \\ Miami, Florida \\ Professor Kenneth G. Furton, Major Professor \\ Professor Rudolf Jaffé, Co - Major Professor
}

The liquid extraction and spectrophotometric quantitation of uranium from different solid matrices is compared to supercritical fluid extraction (SFE) using various combinations of 2,2-dimethyl-6,6,7,7,8,8,8-heptafluoro-3,5-octadione (FOD), tri-n-butylphosphate (TBP), ethanol, and carbon dioxide measuring the UV absorption of the uranium•FOD complex. The matrix is shown to have a tremendous effect on the extractability of uranium from different solid matrices. Compared to liquid extraction, the SFE method yields higher recoveries, is significantly faster, is of equal or greater precision, and greatly reduces the amount of organic solvents used. In the second part of this work, the speciation of hydrophobic organic compounds (HOCs) in ancient sediments is studied by stepwise high temperature SFE and comparisons made to thermodesorption and soxhlet extraction. High 
temperature SFE recovers significantly more HOCs compared to soxhlet extraction. For low molecular weigh compound thermodesorption is the dominant mechanism whereas for high molecular weight compounds the mechanism is a combined effect of thermodesorption and solubility in the supercritical fluid. 


\section{TABLE OF CONTENTS}

\section{SECTION A}

INTRODUCTION

1.1. Supercritical fluid and its unique properties 1

1.2. Supercritical fluid extraction vs. liquid solvent extraction 5

1.3. Extraction of uranyl ion by liquid extraction and supercritical fluid extraction

3.1. Reagents

3.2. Apparatus

3.2.1. Solvent extraction - Stirring 12

3.2.2. Supercritical fluid extraction

3.3. Procedures of stirring extraction

3.4. Procedures of supercritical fluid extraction

4.1. A direct and sensitive UV - Vis absorption spectroscopic method for determination of uranium 
4.2. The effects of the solid matrices on achievable uranium recoveries by liquid extraction

4.3. Supercritical fluid extraction with chelating agent, a better and more efficient method for extraction of uranyl ions than liquid extraction 26

CONCLUSIONS 30

\section{SECTION B}

INTRODUCTION 31

6.1. Speciation of lipids in geological solids . 31

6.2. Supercritical fluid extraction of geological samples 35

OBJECTIVES 38

EXPERIMENTAL 39

8.1. Material 39

8.2. Instrumentation and extraction 40

8.2.1. Supercritical fluid extraction 41

8.2.2. Thermodesorption 42

8.2.3. Soxhlet extraction 44

8.3. Identification and quantification 45

RESULTS AND DISCUSSION 46

9.1. Speciation of lipids in geological samples 46

9.2. Stepwise HT-SFE, thermodesorption and Soxhlet estraction on recovery of hydrocarbons and biomarkers 66 
9.3 Evaluation of the effect of stepwise HT-SFE on recovery of hydrocarbons vs Soxhlet extraction and thermodesorption

CONCLUSION 94

REFERENCES 95 APPENDIX 99 


\section{LIST OF FIGURES}

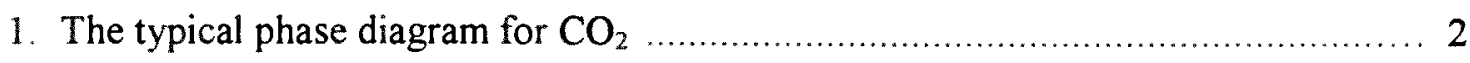

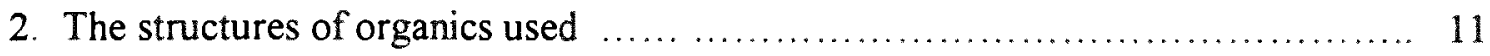

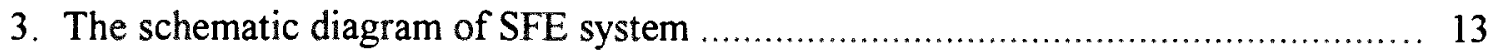

4. The absorbance spectra for the $\mathrm{U}(\mathrm{VI}) \cdot$ FOD complex at 5 different

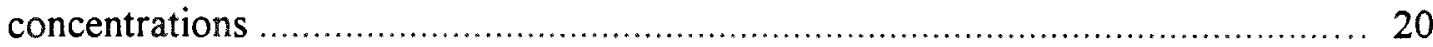

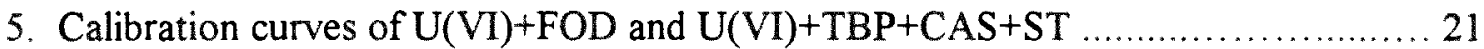

6. Recovery of $\mathrm{U}(\mathrm{VI})$ ions from different matrices using different ethanol solutions

7. Recovery of U(VI) ions from Kaolin using different supercritical $\mathrm{CO}_{2}$ modifiers ... 28

8. Hypothetical structure of sedimentary organic matter with 'trapped' lipids

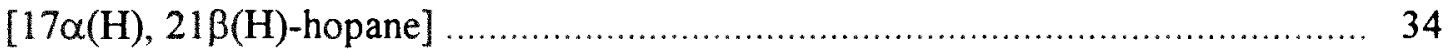

9. Hypothetical speciation of lipids in sediments ........................................... 34

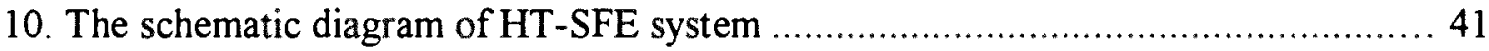

11. The stepwise temperature profile for HT-SFE ............................................ 43

12. The chemical transitions from the precursor molecules to thermally matured hopanes

13. The chemical transitions from the precursor molecules to thermally matured aromatic steranes

14. $m / z=191$ Mass chromatogram of hopanes from stepwise HT-SFE of Posidonia shale at $50^{\circ} \mathrm{C}$

15. $\mathrm{m} / \mathrm{z}=253$ Mass chromatogram of monoaromatic steranes from stepwise 
HT-SFE of Posidonia shale at $50^{\circ} \mathrm{C}$

16. $\mathrm{m} / \mathrm{z}=231$ Mass chromatogram of triaromatic steranes from stepwise

HT-SFE of Posidonia shale at $50^{\circ} \mathrm{C}$

17. Mass chromatograms of hopanes $(\mathrm{m} / \mathrm{z}=191)$ from stepwise HT-SFE of

Posidonia shale at $50^{\circ} \mathrm{C}$ and $350^{\circ} \mathrm{C}$ 58

18. Maturity parameter of $[22 \mathrm{~S} /(22 \mathrm{~S}+22 \mathrm{R})]$ vs. temperature of Posidonia shale 60

19. Maturity parameter of [ $\beta \alpha-$ Moretane/ $\alpha \beta$-Hopane $]$ vs. temperature of Posidonia shale 60

20. Maturity parameter of $[22 S /(22 S+22 R]$ vs. temperature of Kupferschiefer

Shale

21. Maturity parameter of [ $\beta \alpha-$ Moretane/ $\alpha \beta$-Hopane] vs. temperature of Kupferschiefer shale 63

22. Maturity parameter of [TA/(MA+TA)] vs, temperature of Posidonia shale 64

23. Maturity parameter of [TA/(MA+TA)] vs. temperature of Kupferschiefer shale 64

24. $\mathrm{m} / \mathrm{z}=57$ Mass chromatogram of aliphatic hydrocarbons from stepwise HT-SFE of Posidonia shale at $50^{\circ} \mathrm{C}$

25. $\mathrm{m} / \mathrm{z}=128,142,156$ and 170 Mass chromatograms of naphthalene, methyl naphthalenes, dimethyl naphthalenes and trimethyl naphthalenes (aromatic hydrocarbons) from stepwise HT-SFE of Posidonia shale at $50^{\circ} \mathrm{C}$ 67

26. $\mathrm{m} / \mathrm{z}=178,192$, and 206 Mass chromatograms of phenanthrene, methyl phenanthrenes and dimethyl phenanthrenes (aromatic hydrocarbons) from 
stepwise HT-SFE of Posidonia shale at $50^{\circ} \mathrm{C}$ 68

27. $\mathrm{m} / \mathrm{z}=178,192$, and 206 Mass chromatograms of phenanthrene, methyl

phenanthrenes and dimethyl phenanthrenes (aromatic hydrocarbons) from stepwise HT-SFE of Posidonia shale at $350^{\circ} \mathrm{C}$

28. Aliphatic hydrocarbons recovered (ppm) from HT-SFE of Posidonia shale vs. temperature

29. Naphthalenes recovered (ppm) from HT-SFE of Posidonia shale vs. temperature

30. The $\%$ recovery of naphthalene and alkyl-naphthalenes from thermodesorption to recovery from HT-SFE vs temperature

31. The $\%$ recovery of phenanthrene, anthracene, alkyl-phenanthrenes and alkylanthracenes from thermodesorption to recovery from HT-SFE vs temperature

32. Naphthalenes recovered (ppm) from thermodesorption of Posidonia shale vs. temperature

33. Phenanthrenes recovered ( $\mathrm{ppm}$ ) from thermodesorption of Posidonia shale vs. temperature

34. The $\%$ recovery of aliphatic hydrocarbons from thermodesorption to recovery form HT-SFE vs. temperature 90

35. The The \% recovery of naphthalene and alkyl-naphthalenes from thermodesorption to recovery form HT-SFE vs. temperature 90

36. The The \% recovery of phenanthrene, anthracene, alkyl-phenanthrenes and alkylanthracenes from thermodesorption to recovery form HT-SFE vs. temperature ..90 


\section{LIST OF TABLES}

1. Properties of Supercritical fluid vs. those of gas and liquid .......................... 3

2. Critical parameters of possible supercritical fluids ......................................... 3

3. \% Recovery of U(VI) ions (S.D.) with different matrices using different liquid solvents by stirring extraction

4. \% Recovery of U(VI) ions (S.D.) with different matrices using different liquid solvents by SFE

5. The peaks identified for $m / z=191$ (hopanes) mass chromatogram from stepwise HT-SFE of Posidonia shale at $50^{\circ} \mathrm{C}$

6. The peaks identified for $\mathrm{m} / \mathrm{z}=253$ (monoaromatic steranes) mass chromatogram from stepwise HT-SFE of Posidonia shale at $50^{\circ} \mathrm{C}$

7. The peaks identified for $\mathrm{m} / \mathrm{z}=231$ (triaromatic steranes) mass chromatogram from stepwise HT-SFE of Posidonia shale at $50^{\circ} \mathrm{C}$

8. Recoveries of Hopanes (S.D.) from triplicate stepwise HT-SFE of Posidonia shale

9. Recoveries of monoaromatic steranes (S.D.) from triplicate stepwise HT-SFE of Posidonia shale

10. Recoveries of triaromatic steranes (S.D.) from triplicate stepwise HT-SFE of Posidonia shale

11. Recoveries of Hopanes (S.D.) from single stepwise HT-SFE of Kupferschiefer shale 56

12. Recoveries of monoaromatic steranes (S.D.) from triplicate stepwise 
13. Recoveries of triaromatic steranes (S.D.) from single stepwise HT-SFE of Kupferschiefer shale

14. Maturity parameter of $[22 \mathrm{~S} /(22 \mathrm{~S}+22 \mathrm{R})]$ for Posidonia shale from triplicate stepwise HT-SFE

15. Maturity parameter of [ $\beta \alpha-$ Moretane/ $\alpha \beta$-Hopane] for Posidonia shale from triplicate stepwise HT-SFE

16. Maturity parameter of $[22 S /(22 S+22 R)]$ for Kupferschiefer shale from single stepwise HT-SFE

17. Maturity parameter of [ $\beta \alpha-$ Moretane/ $\alpha \beta$-Hopane] for Kupferschiefer shale from single stepwise HT-SFE

18. Maturity parameter of $[\mathrm{TA} /(\mathrm{TA}+\mathrm{MA})]$ for Posidonia shale from triplicate stepwise HT-SFE

19. Maturity parameter of $[\mathrm{TA} /(\mathrm{TA}+\mathrm{MA})]$ for Kupferschiefer shale from single stepwise HT-SFE

20. The peaks identified for $\mathrm{m} / \mathrm{z}=57$ (aliphatic hydrocarbons) mass chromatogram from stepwise $\mathrm{HT}$-SFE of Posidonia shale at $50^{\circ} \mathrm{C}$

21. The peaks identified for $\mathrm{m} / \mathrm{z}=128,142,156$ and 170 (aromatic hydrocarbons) mass chromatogram from stepwise HT-SFE of Posidonia shale at $50^{\circ} \mathrm{C}$ 70

22. The peaks identified for $\mathrm{m} / \mathrm{z}=178,192$, and 206 (aromatic hydrocarbons) mass chromatogram from stepwise HT-SFE of Posidonia shale at $50^{\circ} \mathrm{C}$ and $350^{\circ} \mathrm{C}$ 
23. Recovery of aliphatic hydrocarbons (S.D.) from triplicate stepwise HT-SFE of Posidonia shale

24. Recovery of naphthalenes (aromatic hydrocarbons) (S.D.) from triplicate stepwise HT-SFE of Posidonia shale

25. Recovery of phenanthrenes (aromatic hydrocarbons) (S.D.) from triplicate stepwise HT-SFE of Posidonia shale

26. Recovery of aliphatic hydrocarbons (S.D.) from triplicate thermodesorption of Posidonia shale 78

27. Recovery of naphthalenes (aromatic hydrocarbons) (S.D.) from triplicate thermodesorption of Posidonia shale 79

28. Recovery of phenanthrenes (aromatic hydrocarbons) (S.D.) from triplicate thermodesorption of Posidonia shale 80

29. Recovery of aliphatic hydrocarbons from single Soxhlet extraction of

Posidonia shale 83

30. Recovery of naphthalenes (aromatic hydrocarbons) from single Soxhlet extraction of Posidonia shale 84

31. Recovery of phenanthrenes (aromatic hydrocarbons) from single Soxhlet extraction of Posidonia shale 84

32. Recovery of hopanes from single Soxhlet extraction of Posidonia shale 85

33. Recovery of monoaromatic steranes from single Soxhlet extraction of Posidonia shale 86

34. Recovery of triaromatic steranes from single Soxhlet extraction of 
Posidonia shale

35. Accumulative recovery of hydrocarbons and biomarkers ( $\mathrm{ppm}$ ) from triplicate thermodesorption and HT-SFE, as well as the \% recovery from thermodesorption to recovery from HT-SFE (in parenthesis)

36. Accumulative recovery of hydrocarbons and biomarkers ( $\mathrm{ppm}$ ) from single Soxhlet extraction and triplicate HT-SFE, as well as the \% recovery from HT-SFE to recovery from Soxhlet extraction (in parenthesis) 


\section{SECTION A}

\section{INTRODUCTION}

\subsection{Supercritical fluid and its unique properties}

A supercritical fluid is a liquid or gas heated above its critical temperature (Tc) and simultaneously compressed, exceeding its critical pressure (Pc). The supercritical fluid region in the schematic phase diagram of $\mathrm{CO}_{2}$, shown in Figure 1, represents an extension of the gas and liquid phase regions in which there is no longer distinction between the gas and the liquid and the physicochemical properties of the fluid are continuously variable between those of gas and liquid by changing the temperature and pressure above the critical point.

Table 1 illustrates the properties of supercritical fluid vs. those of gas and liquid.

In general, while the density and viscosity of supercritical fluid, along with the diffusion coefficient of the solute (the analyte) in supercritical fluid are variable between those of gas and liquid, the density is closer to that of liquid, and the viscosity as well as the diffusion coefficient of the analytes is closer to that of gas. In addition, the surface tension of supercritical fluid is zero. Those properties make supercritical fluid a fluid with high solvating power (due to liquid-like density), efficient penetration ability (due to gaslike viscosity and zero surface tension) and give analytes in supercritical fluid rapid transportation ability (due to gas-like diffusion coefficient of solute in supercritical fluid).

Table 2 lists the critical parameters of possible supercritical fluids. Among those 


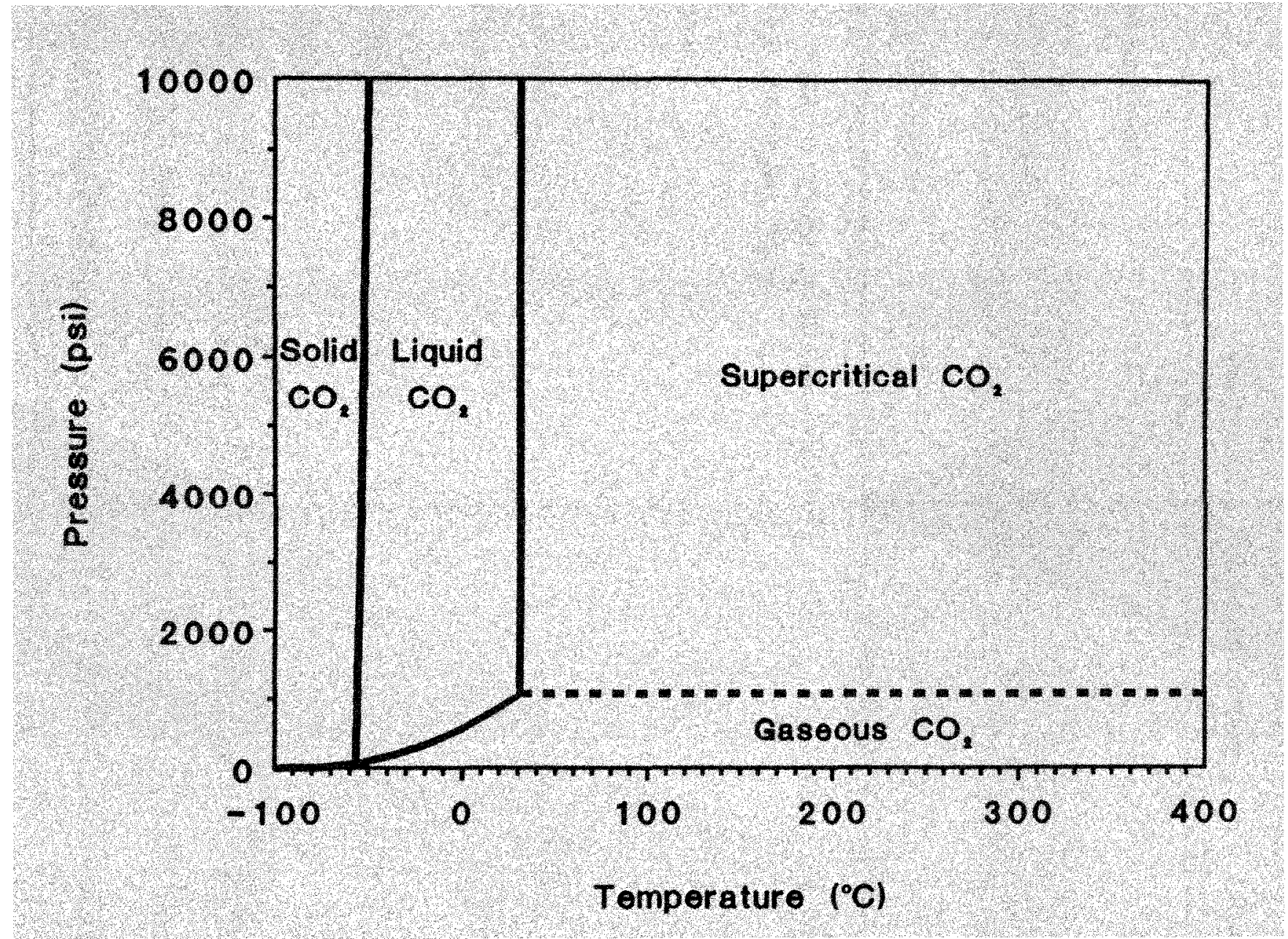

Figure 1. The typical phase diagram for $\mathrm{CO}_{2}$. 


\begin{tabular}{|c|c|c|c|}
\hline & Gas & Supercritical fluid & Liquid \\
\hline Density $\left(\mathrm{g} / \mathrm{cm}^{3}\right)$ & $10^{-3}$ & $0.1-1$ & 1 \\
\hline O) & $10 \%$ & $10^{3} \cdot 10^{4}$ & $=10^{3}$ \\
\hline Viscosity $(\mathrm{g} / \mathrm{cm} \cdot \mathrm{s})$ & $10^{-4}$ & $10^{-3}-10^{-4}$ & $10^{-2}$ \\
\hline
\end{tabular}

Table 1. Properties of supercritical fluid vs. those of gas and liquid (taken from McNally and Bright, 1992)

\begin{tabular}{|c|c|c|c|}
\hline Formula & Name & Pc (psi) & $\mathrm{Tc}\left({ }^{\circ} \mathrm{C}\right)$ \\
\hline $\mathrm{CO}_{2}$ & Carbon Dioxide & 1070.4 & 31.1 \\
\hline $1 / 11$ & Elbylene & 1310 & 94 \\
\hline $\mathrm{C}_{5} \mathrm{H}_{12}$ & n-Pentane & 488.8 & 196.7 \\
\hline 120 & Nitrous Oxide & 10501 & 360 \\
\hline $\mathrm{C}_{3} \mathrm{H}_{6}$ & Propylene & 677.2 & 91.9 \\
\hline $\mathrm{C}_{11}, 6 \mathrm{O}$ & Helhyl Ether. & 8270 & $193 \%$ \\
\hline $\mathrm{H}_{2} \mathrm{O}$ & Water & 3208.2 & 374.3 \\
\hline $1 \mathrm{NI}_{3}$ & Anntonia & $1651 \%$ & $13 \%$ \\
\hline $\mathrm{Xe}$ & Xenon & 857.5 & 16.6 \\
\hline$(8+2)$ & Drollorodifluoromeflare & 5976 & 1120 \\
\hline $\mathrm{CHF}_{3}$ & Trifluoromethane & 688.6 & 25.6 \\
\hline
\end{tabular}

Table 2. Critical parameters of possible supercritical fluids 
supercritical fluids listed, carbon dioxide has been so far the most commonly used one, because of its moderate critical constants, ineptness, non-toxicity, non-flammability and availability in purified form. However, because it is non-polar, supercritical $\mathrm{CO}_{2}$ has a limited affinity with polar analytes, especially with ion species. It is common now to add small amount of polar modifier to supercritical $\mathrm{CO}_{2}$ for polar analytes and, recently, to convert the charged species into chelates by using a chelation agent in supercritical $\mathrm{CO}_{2}$. 


\subsection{Supercritical fluid extraction vs. liquid solvent extraction}

The main task of extraction is to separate analytes from a matrix by investing the minimum amount of effort and time necessary to provide quantitation with acceptably high degrees of accuracy and precision (Miles et al., 1992). Over the decades, for analytes in solid matrix the extraction was achieved mainly by liquid solvent extraction, such as Soxhlet extraction and stirring extraction, as well as sonication. Unfortunately, the conventional liquid solvent extractions often fail to meet the goals of extraction described before. They often require several hours, even days, to perform, and may result in a dilute extract, which must be concentrated when trace analysis is desired. They may also generate large amounts of hazardous waste solvent and may not result in quantitative recovery of target analytes. The limitations of conventional methods support the development of alternative sample extraction methods (Hawthorne, 1990)

The continuously variable physicochemical properties (density, diffusivity, viscosity, etc) of supercritical fluid described before make it an excellent candidate for extraction and recovery of analytes from solid matrix - supercritical fluid extraction (SFE). Because of its unique properties, carbon dioxide has been the most commonly used supercritical fluid in SFE.

SFE is much more efficient than conventional solvent extraction (usually $10-60$ mins), because of the ability of supercritical fluid to rapidly penetrate into matrix and the ability of analytes to rapidly transport out of matrix. Supercritical $\mathrm{CO}_{2}$ is a non-toxic gas at ambient conditions. Therefore, much less hazardous waste solvent is generated and the concentration steps are much simpler. Most importantly, SFE usually has higher recovery 
of the analytes of interest than conventional solvent extraction.

The recovery of the analytes from solid matrices depends on solubility and diffusion coefficient of the analytes in a solvent or fluid, and particularly, the affinity of the analytes for the matrices, and the speciation of analytes in the solid matrix (the way the analytes associate with the solid matrix) (Furton and Rein, 1992; Furton and Lin, 1993; Knipe et al., 1992; Hawthorne et al., 1993). Although the solubility of the analytes in supercritical fluid is smaller than that in proper solvent, the diffusion coefficient of the analytes is much greater. Because of the variable physicochemical properties of supercritical fluid under different temperature and pressure, and because of the controllable SFE variables, such as temperature, pressure, fluid modifiers and fluid flow rate etc, the overall recovery of SFE can be optimized. 


\subsection{Extraction of uranyl ion by liquid extraction and supercritical fluid extraction}

With the development and application of nuclear power, uranium has become an extremely important energy source. The mining and processing of uranium ores have perceptible effects on the environment (Edwards et al., 1992). Sensitive and accurate methods for uranium nuclear waste analysis, purification and management are therefore required.

The solvent extraction of uranium has been studied by a great number of investigators. Organophosphorus compounds have attracted considerable interest as solvent extracting agents for uranyl ions, $\mathrm{U}(\mathrm{VI})$, as well as a large variety of other metal ions. Amongst these, neutral ligands, including the phosphoryl group $\mathrm{P}=\mathrm{O}$, are of special importance (Rodehuser et al., 1992). Tri-n-butyl phosphate (TBP) is one of the first and most widely used solvent extractants. TBP dissolved in the hydrocarbon diluent (typically $70 \%$ ) is widely used to extract $\mathrm{U}(\mathrm{VI})$ from nitric acidic solutions in counter-current solvent extraction processes (Enokida et al., 1992). Alternatively, uranium had been extracted from nitrate solutions, using TBP adsorbed onto insoluble polymers (Britz et al., 1990). Over the years, a variety of synergistic uranium extractions have been reported, including mixtures of TBP and chelating extractants (often $\beta$-diketones). It has also been shown that uranium can be effectively extracted from acidic media using emulsion liquid membranes containing $\beta$-diketones and TBP (Akiba et al., 1988). However, these liquid extraction methods are either time consuming or complicated. Relatively large amounts of organic solvent waste are also generated.

Supercritical carbon dioxide extraction has several advantages over conventional 
liquid extraction, as mentioned before. However, direct extraction of uranyl ions by supercritical $\mathrm{CO}_{2}$ is highly inefficient because of the weak solute-fluid interactions (Laintz et al., 1992). Recently, Lin et al. have reported the use of fluorinated $\beta$-diketones, 2,2dimethyl-6,6,7,7,8,8,8,-heptafluoro-3,5,-octadione (FOD) (Lin et al., 1993) as chelating agents, dissolved in supercritical $\mathrm{CO}_{2}$ for the recovery of lanthanides and actinides (including uranyl ions) from solid materials followed by quantitation by neutron activation analysis (NAA). This method has shown all advantages of SFE over liquid extraction. However, the sample matrix used was filter paper, which is markedly different from real environmental matrix. In addition, neutron activation analysis (NAA) requires very expensive instrument and is not a readily available technique. 


\section{OBJECTIVES}

The objectives of this work were:

1. To develop a rapid sensitive spectroscopic method utilizing the inexpensive and readily available UV-Vis absorption spectrometer for detecting a wide range of uranium concentrations without the need for post-extraction complex formation.

2. To evaluate the effects of the solid matrices, one of them mimicking real environmental matrix, on achievable uranium recoveries by liquid extraction.

3. To compare liquid and supercritical fluid extraction methods in terms of recovery, precision, ease of use and time of analysis. 


\section{EXPERIMENTAL}

\subsection{Reagents}

All chemicals used were purchased in the highest purity available and used without further purification. Absolute ethyl alcohol (ethanol) was purchased from Florida Distillers (Lake Alfred, FL). Tributylphosphate (TBP) and acetic acid were purchased from Fisher Scientific (Orlando, FL). Kaolin $\left[\mathrm{Al}_{2} \mathrm{SiO}_{5}(\mathrm{OH})_{4}\right]$ (china clay), 2,2-dimethy6,6,7,7,8,8,8,-heptafluoro-3.5-octadione (FOD), chrome azurol $\mathrm{S}$ (CAS) benzyldimethyldodecylammonium bromide (sterinol ST) and sodium acetate were obtained from Aldrich (Milwaukee, WI) (see Figure 2 for structures of organics used). Uranyl nitrate hexahydrate $(>99 \%)\left[\mathrm{UO}_{2}\left(\mathrm{NO}_{3}\right)_{2} \cdot 6 \mathrm{H}_{2} \mathrm{O}\right]$ was obtained from Baker (Phillipsburg, NJ). 50\% polypropylene/50\% polyester and $100 \%$ cotton balls were obtained from Sentinel (Mentor, $\mathrm{OH}$ ). DMCS treated glass wool was obtained from Altech (Deerfield, IL). SFC/SFE grade carbon dioxide (Air Products, Allentown, PA) was used for all supercritical fluid extractions. 


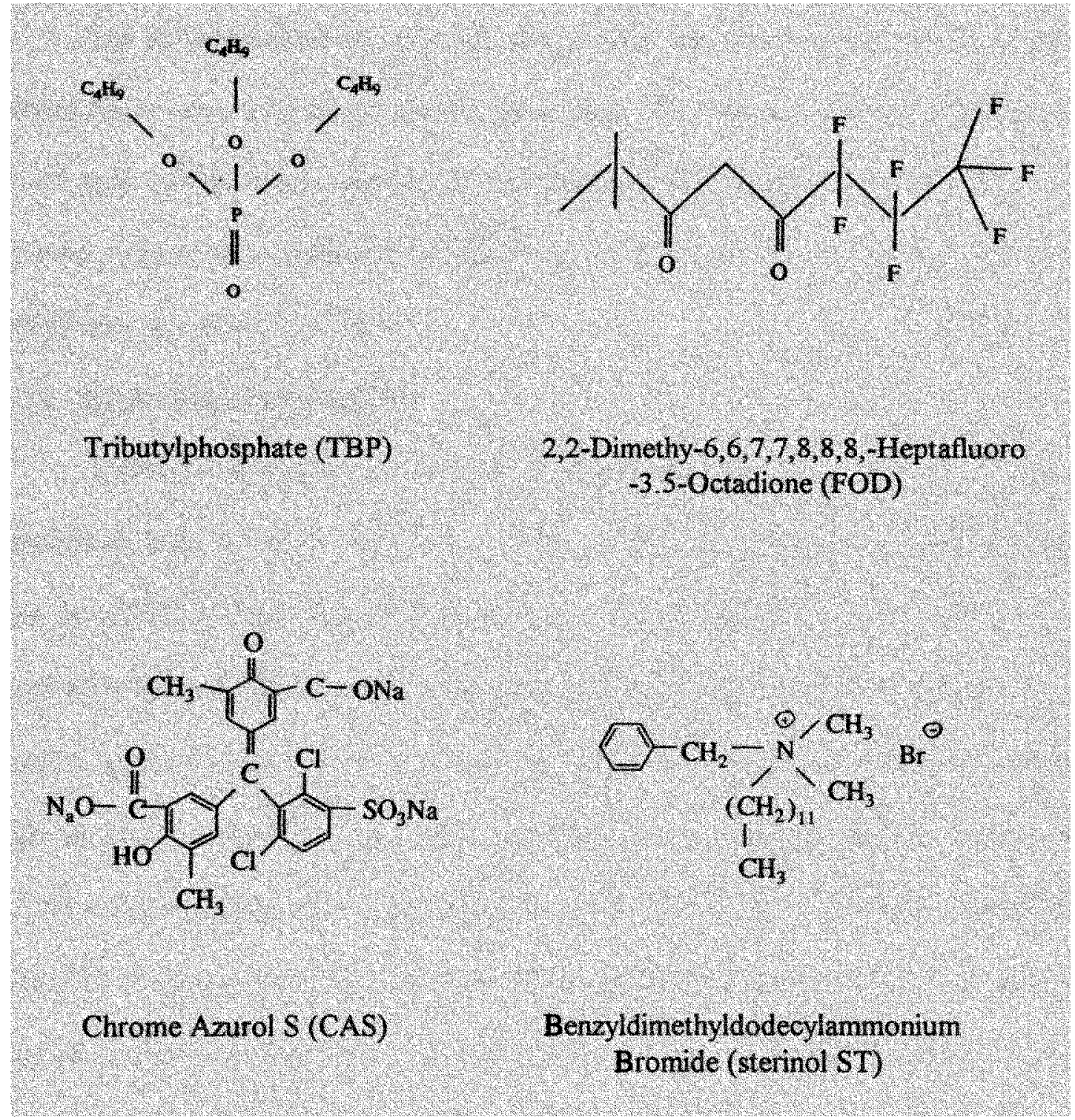

Figure 2. The structures of organics used 


\subsection{Apparatus}

\subsubsection{Solvent extraction - stirring}

The solvent extraction used for this project was stirring extraction. Corning stirring plates were used for all solvent extractions. The extracts, when necessary, were centrifuged with an Adams compact II centrifuge (Becton Dickinson, Sparks, MD). All volumes needed were measured by enpendorf 1-100, 100-1000 ul pipette (Brinkmann Instruments Inc, Westbury, NY).

\subsubsection{Supercritical fluid extraction}

A microprocessor-controlled 260D syringe pump and SFX 2-10 extractor (max. temperature limit at $150^{\circ} \mathrm{C}$ ) with a $2.5 \mathrm{ml}$ extraction vessel (ISCO. Lincoln, NE) were used for all of the supercritical fluid extractions. A $15 \mathrm{~cm} \times 50 \mu \mathrm{m}$ i.d., $375 \mu \mathrm{m} \mathrm{o.d}$. fused-silica capillary linear restrictor (Polymicro Technologies, Phoenix, AZ) covered by stainless steel tubing ( $8 \mathrm{~cm} \times 500 \mu \mathrm{m}$ i.d., $1.5 \mathrm{~mm}$ o.d.) was inserted through a $1.5 \mathrm{~mm}$ diameter hole drilled through the aluminum heating block. The heating block was heated to $250^{\circ} \mathrm{C}$ with a silicon extruded heating tape controlled with a stepless temperature controller (Thermolyne, Dubuque, IA). The schematic diagram of SFE system for uranium is shown in Figure 3. Analytes were collected in $2 \mathrm{ml}$ of ethanol in a $5 \mathrm{ml}$ volumetric flask. Absorbances of standards and extracts were measured in $1.00 \mathrm{~cm}$ Supracil quartz cuvettes (Fisher Scientific, Orlando, FL) using a Shimadzu UV-2101 PC UV-visible scanning spectrophotometer (Columbia, MD). 


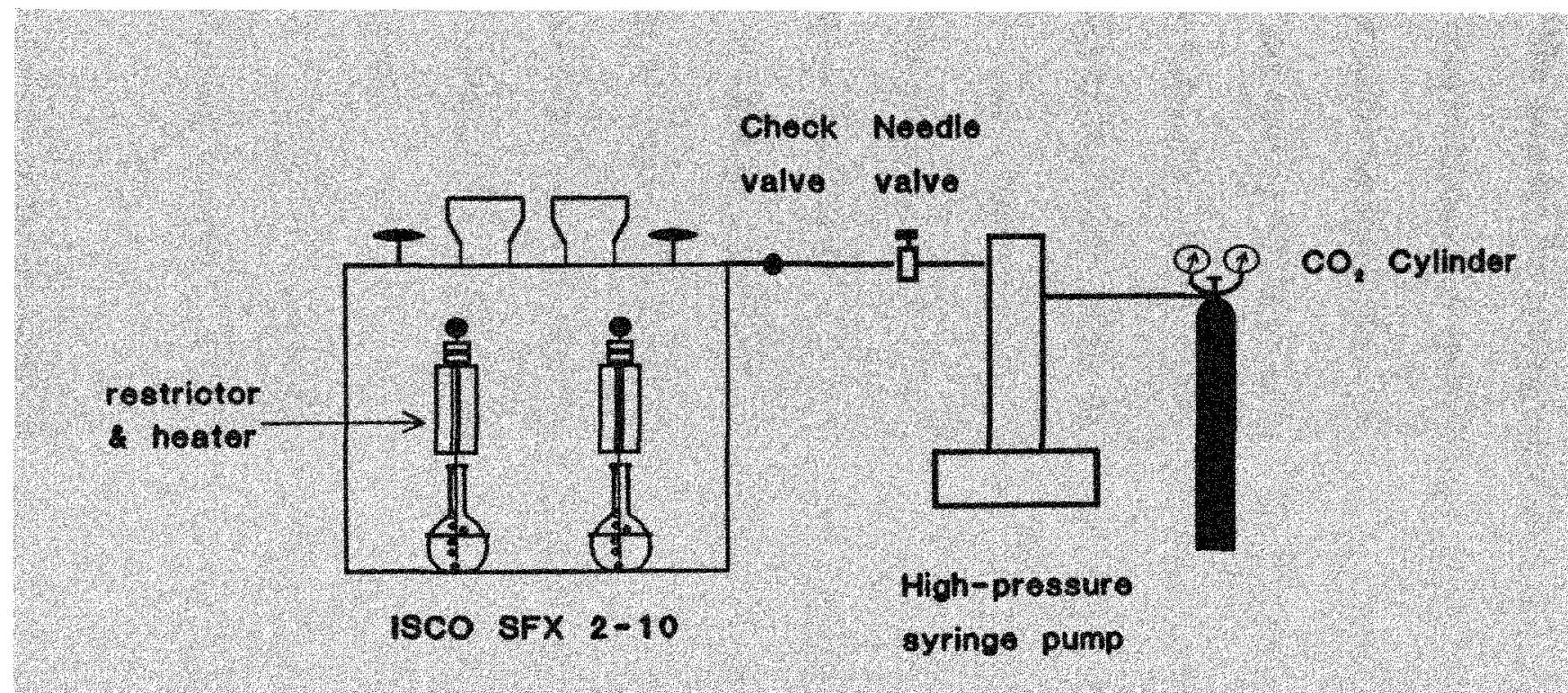

Figure 3. The schematic diagram of SFE system 


\subsection{Procedures of stirring extraction}

The samples for stirring extraction were prepared by spiking certain amount of uranyl nitrate hexahydrate $\left[\mathrm{UO}_{2}\left(\mathrm{NO}_{3}\right)_{2} \cdot 6 \mathrm{H}_{2} \mathrm{O}\right]$ solution, dissolved in ethanol, onto 3 different solid matrices: DMCS treated glass wool, polypropylene/polyester and cotton, and by pre-coating $\mathrm{UO}_{2}\left(\mathrm{NO}_{3}\right)_{2} \cdot 6 \mathrm{H}_{2} \mathrm{O}$ solution onto Kaolin (Kaolin packing) (mimicking real environmental matrix). A $660 \mathrm{ppm} \mathrm{UO}_{2}\left(\mathrm{NO}_{3}\right)_{2} \cdot 6 \mathrm{H}_{2} \mathrm{O}$ stock solution was prepared by dissolving $0.07 \mathrm{~g}$ uranyl nitrate hexahydrate in $50 \mathrm{ml}$ of ethanol, and $100 \mu$ of this stock solution was then spiked onto $0.1 \mathrm{~g}$ samples of matrix: glass wool, polypropylene/polyester and cotton. The matrices were allowed to dry at room temperature. A standard Kaolin packing containing 54 ppm U(VI) was prepared by adding $21.1003 \mathrm{~g}$ of Kaolin to a methanolic solution of $\mathrm{UO}_{2}\left(\mathrm{NO}_{3}\right)_{2} \cdot 6 \mathrm{H}_{2} \mathrm{O}$, containing $0.0024 \mathrm{~g}$ of $\mathrm{UO}_{2}\left(\mathrm{NO}_{3}\right)_{2} \cdot 6 \mathrm{H}_{2} \mathrm{O}$, in a glass jar. The methanol was allowed to evaporate at room temperature and the packing was then transferred to another container. The glass jar was extracted and no $U(V I)$ was detected, indicating quantitative transfer of the U(VI) to the Kaolin.

$0.1 \mathrm{~g}$ glass wool, polypropylene/polyester and cotton samples, pre-spiked with $\mathrm{UO}_{2}\left(\mathrm{NO}_{3}\right)_{2} \cdot 6 \mathrm{H}_{2} \mathrm{O}$ standard solution, were extracted by 5 different solvents described below:

(1) $5 \mathrm{ml}$ of absolute ethanol

(2) $5 \mathrm{ml}$ of absolute ethanol buffered to $\mathrm{pH} 5.5$ with $0.662 \mathrm{ml}$ of $\mathrm{pH} 3.2$ acetic acid-sodium acetate buffer 
(3) $5 \mathrm{ml}$ of absolute ethanol and $2.5 \mathrm{ml}$ of TBP buffered to $\mathrm{pH} 5$ with $0.662 \mathrm{ml}$ of pH 3.2 acetic acid-sodium acetate buffer

(4) $4.886 \mathrm{ml}$ of absolute ethanol, along with $0.114 \mathrm{ml}$ of FOD (0.1 M)

(5) $4.752 \mathrm{ml}$ of absolute ethanol, along with $0.114 \mathrm{ml}$ of FOD (0.1M) and 0.134 $\mathrm{ml}$ of TBP $(0.1 \mathrm{M})$

$2 \mathrm{~g}$ of the Kaolin packing was extracted in the same manner as described above, but with 1.5 times of total solvent amount. The pre-spiked matrices and Kaolin packing were placed in beakers covered by watch glasses to prevent evaporation and stirred for 45 mins at room temperature. The extracts for Kaolin packing were then transferred to centrifuge tubes and centrifuged for 10 mins. Half of the total volume $(2.5 \mathrm{ml})$ of the extracts for glass wool, polyethylene/polyester and cotton extraction and $2.5 \mathrm{ml}$ of the extracts for Kaolin extraction were then individually pipetted into $5.0 \mathrm{ml}$ volumetric flasks and diluted with neat ethanol for the extracts, which included FOD (extractions 4 and 5), or visualized with CAS/ST complexation (extraction 1,2 and 3) as described below.

Trace quantities of U(VI) or U(VI) complex were not sensitive enough for direct determination by UV-Vis spectrophotometer, except for the presence of FOD. The extracts from extraction 1,2 and 3 were analyzed by UV-Vis using a post-extraction visualization. The post-extraction visualization was accomplished with a complex (with $\mathrm{pH} 5$ ) formed in the presence of U(VI), $0.525 \mathrm{ml}$ of $1.52 \times 10^{-3} \mathrm{CAS}, 0.394 \mathrm{ml}$ of $3.2 \mathrm{x}$ $10^{-2} \mathrm{M} \mathrm{ST}, 1.25 \mathrm{ml}$ of TBP, $2.5 \mathrm{ml}$ of ethanol and $0.331 \mathrm{ml}$ of $\mathrm{pH} 3.2$ acetic acid-sodium acetate buffer. Therefore, CAS and ST (for extracts 1, 2 and 3), TBP (for extracts 1 and 2), as well as buffer (for extract 1 ) were added. $100 \mu \mathrm{l}$ of U(VI) stock solution was added 
into each solvent (without matrices), with the same combination and amount as what described before, as a standard solution. The standard solution was simultaneously extracted in the same manner of U(VI)-matrix-solvent extraction. The recoveries of U(VI) from different matrices were obtained from comparing the UV absorbance of U(VI) complex from standard solution and extracts. 


\subsection{Procedures of SFE}

The sample used for SFE was pre-coated Kaolin only. The standard Kaolin packing containing $65 \mathrm{ppm}$ U(VI) was prepared by adding $21.8290 \mathrm{~g}$ of Kaolin to a methanolic solution of $\mathrm{UO}\left(\mathrm{NO}_{3}\right)_{2} \cdot 6 \mathrm{H}_{2} \mathrm{O}$, containing $0.0030 \mathrm{~g}$ of $\mathrm{UO}\left(\mathrm{NO}_{3}\right)_{2} \cdot 6 \mathrm{H}_{2} \mathrm{O}$, in a glass jar. The post-treatments of Kaolin packing as described in section 3.3 were also performed. $\quad 0.7 \mathrm{~g}$ of the Kaolin packing was extracted in a $2.5 \mathrm{ml}$ extraction vessel in the static mode for 20 mins at $70^{\circ} \mathrm{C}$ and 5000 psi followed by 10 min dynamic extraction with pure supercritical $\mathrm{CO}_{2}$ at a flow rate of $1.0 \mathrm{ml} / \mathrm{min}$ using a $15 \mathrm{~cm} \times 50 \mu \mathrm{m}$ i.d. linear restrictor. The following modifiers were spiked into the $2.5 \mathrm{ml}$ extraction vessel for the static extraction step:

(1) $5.6 \% \mathrm{v} / \mathrm{v}$ absolute ethanol- $\mathrm{CO}_{2}(140 \mu \mathrm{l}$ ethanol $/ 2.5 \mathrm{ml}$ cell $)$

(2) $5.6 \% \mathrm{v} / \mathrm{v}$ absolute ethanol and $0.1 \mathrm{M}$ TBP $-\mathrm{CO}_{2}(140 \mu \mathrm{l}$ of TBP+ethanol solution prepared by pipetting $2.38 \mathrm{o} \mathrm{ml}$ of TBP diluted to $5 \mathrm{ml}$ with ethanol/2.5 ml cell)

(3) $0.1 \mathrm{M} \mathrm{FOD}-\mathrm{CO}_{2}(57 \mu \mathrm{FOD} / 2.5 \mathrm{ml}$ cell $)$

(4) $0.1 \mathrm{M}$ of TBP and $0.1 \mathrm{M}$ of FOD $-\mathrm{CO}_{2}(124 \mu 1$ of FOD+TBP solution prepared by combining $2.036 \mathrm{ml}$ FOD and $2.38 \mathrm{ml} \mathrm{TBP} / 2.5 \mathrm{ml}$ cell)

(5) $5.6 \% \mathrm{v} / \mathrm{v}$ absolute ethanol and $0.1 \mathrm{M}$ FOD $-\mathrm{CO}_{2}(140 \mu \mathrm{l}$ of FOD+ethanol solution prepared by pipeting $2.036 \mathrm{ml}$ FOD diluted to $5 \mathrm{ml}$ with ethanol $/ 2.5 \mathrm{ml}$ cell)

(6) $5.6 \%$ absolute ethanol and $0.1 \mathrm{M}$ FOD and $0.1 \mathrm{M} \mathrm{TBP}-\mathrm{CO}_{2}(140 \mu \mathrm{l}$ of FOD+TBP+ethanol solution prepared by pipetting $2.036 \mathrm{ml}$ FOD and $2.380 \mathrm{ml}$ TBP diluted to $5 \mathrm{ml}$ with ethanol $/ 2.5 \mathrm{ml}$ cell) 
The extracts were diluted to $5 \mathrm{ml}$ with visualizing agents in the same manner as described in section 3.3 (for extracts 1 and 2) and ethanol (for extracts 3, 4, 5 and 6) before quantitation.

Two calibration curves, achieved from measuring the UV absorption of (i) 5 standard solutions varying from 2 to $14 \mathrm{ppm}$ of $\mathrm{U}(\mathrm{VI})$ ion in the presence of visualizing reagents and (ii) 15 standard solutions varying from $40 \mathrm{ppb}$ to $85 \mathrm{ppm}$ of U(VI) in the presence of 0.1 M FOD, were used for recovery calculations of extraction (1)-(2) and (3)-(6) respectively (see section 4.1. for detailed information about calibration curves).

5 standard solutions varying from 2 to $14 \mathrm{ppm}$ were prepared by diluting a 1034 ppm $\mathrm{UO}_{2}(\mathrm{NO} 3)_{2} \cdot 6 \mathrm{H}_{2} \mathrm{O}$ stock solution, prepared by dissolving $0.1090 \mathrm{~g} \mathrm{UO}_{2}\left(\mathrm{NO}_{3}\right)_{2} \cdot 6 \mathrm{H}_{2} \mathrm{O}$ in $50 \mathrm{ml}$. volumetric flask with ethanol, with ethanol in the presence of visualizing reagents in the same manner as described in section 3.3. 15 standard solutions varying from $40 \mathrm{ppb}$

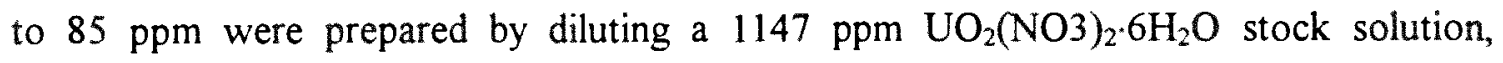
prepared by dissolving $0.0605 \mathrm{~g} \mathrm{UO}_{2}(\mathrm{NO} 3)_{2} \cdot 6 \mathrm{H}_{2} \mathrm{O}$ in $25 \mathrm{ml}$ volumetric flask with ethanol, with ethanol in the presence of 0.1 M FOD. 


\section{RESULTS AND DISCUSSION}

4.1. A direct and sensitive UV-Vis absorption spectroscopic method for determination of uranium

Uranium [U(VI)] extracted with FOD was directly measured by UV-Vis spectrophotometer. The U(VI).FOD complex showed a maximum absorbance at $361 \mathrm{~nm}$. Absorbance spectra for the U(VI) FOD complex at 5 different concentrations are shown in Figure 4. UV absorption spectra were measured for 15 standard solutions varying from $40 \mathrm{ppb}$ to $85 \mathrm{ppm}$ of $\mathrm{U}(\mathrm{VI})$ in the presence of the $0.10 \mathrm{M}$ FOD in ethanol. Absorbances were measured at the $\lambda_{\max }$ of $361 \mathrm{~nm}$ and slight variations in baseline were corrected by subtracting the absorbances observed at $426 \mathrm{~nm}$. Linear least squares regression of the data for the U(VI).FOD complex yielded the following: absorbance at $361-426 \mathrm{~nm}=$ $0.022\left[\mathrm{U}_{\mathrm{ppm}}\right]+0.009\left(\right.$ S.D. of the slope $=0.001 ;$ S.D. of the intercept $\left.=0.003 ; \mathrm{r}^{2}=0.999\right)$ (Figure 5). Absorbance spectra measured from $2 \mathrm{ppm}$ to $50 \mathrm{ppm}$ of $\mathrm{U}(\mathrm{VI})$ in the presence of $0.1 \mathrm{M}$ FOD and $0.1 \mathrm{M}$ TBP in ethanol were compared to that in the presence of $0.1 \mathrm{M}$ FOD only. Both calibration curves are identical, therefore, the calibration curve from U(VI).FOD is allowed to be used for all extractions, which included FOD. Beer's law is obeyed over three orders of magnitude from below $100 \mathrm{ppb}$ to nearly $100 \mathrm{ppm}$ of U(VI).FOD. The molar absorptivity of the U.FOD complex at $\lambda_{\max }=361 \mathrm{~nm}$ is $5.2 \times 10^{3} 1$ $\mathrm{mol}^{-1} \mathrm{~cm}^{-1}$.Uranium

[U(VI)] extracted without FOD was converted to a colored complex in a manner similar to that proposed by Kwapulinska and Janoszka using aqueous solutions of Chrome 


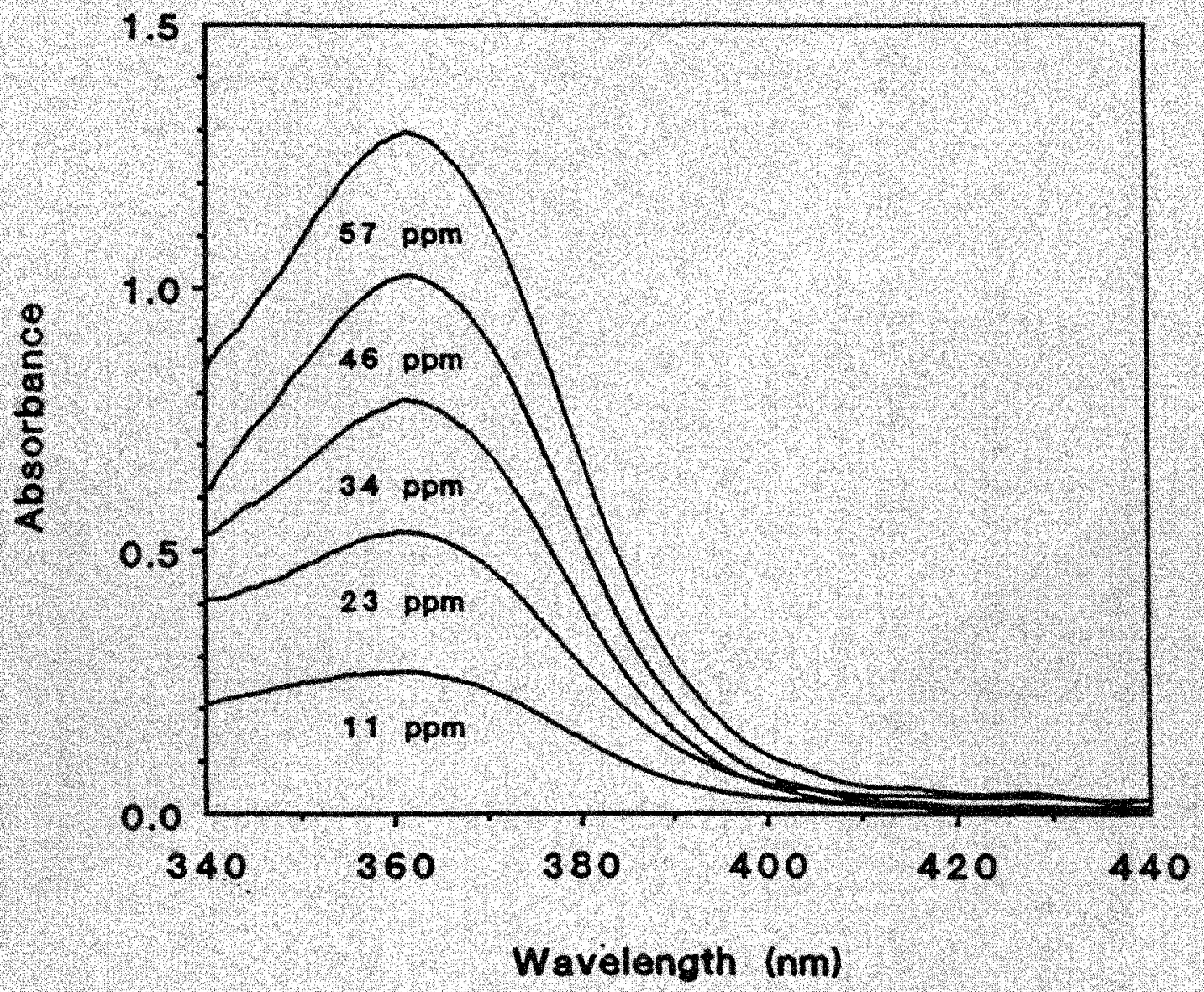

Figure 4. The absorbance spectra for the U(VI)-FOD complex at 5 different concentrations 


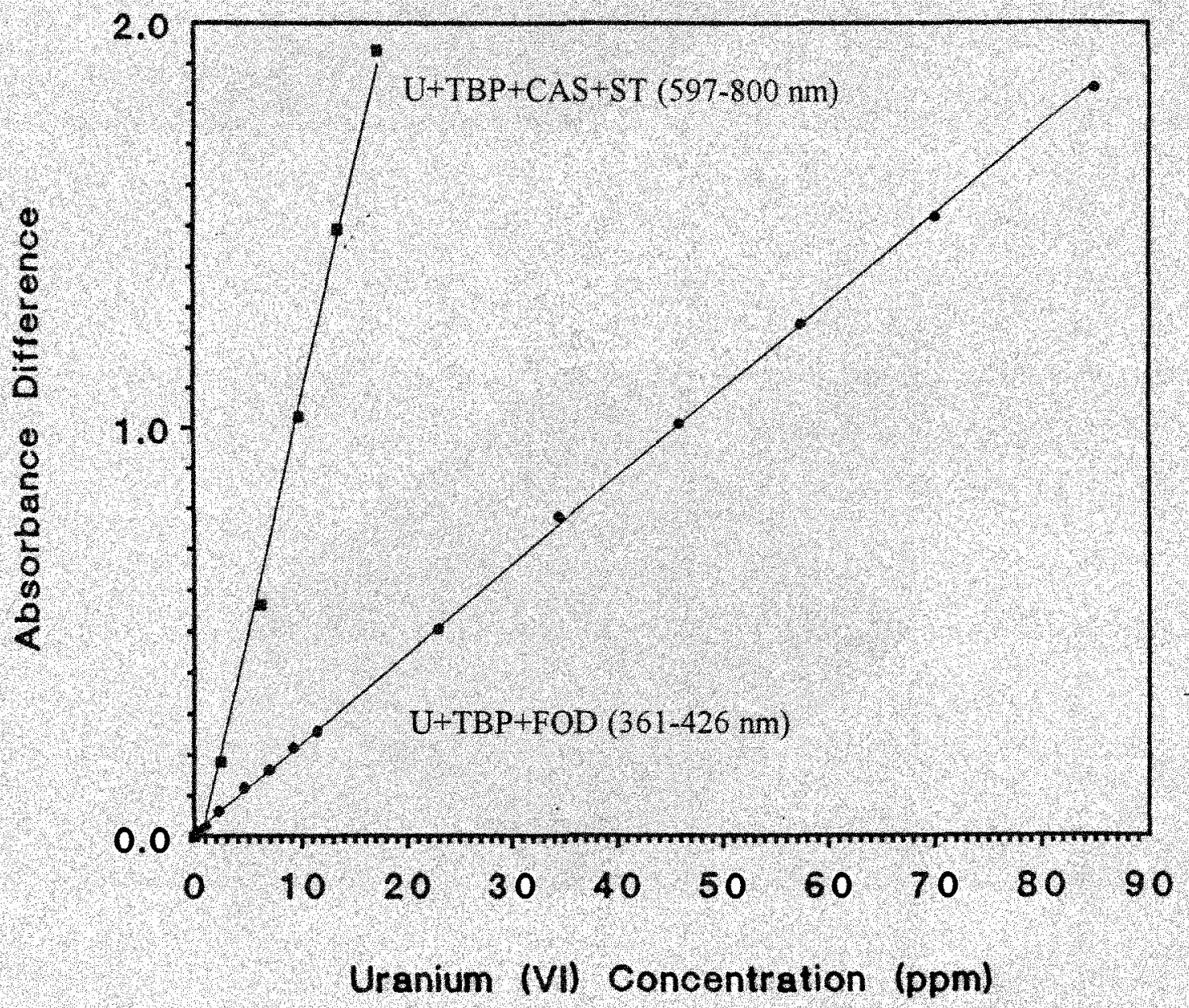

Figure 5. Calibration curves of $U(V I)+F O D$ and $U(V I)+T B P+C A S+S T$ 
Azurol S (CAS) and benzyldimethydodecylamonium bromide (ST) (1990). The present method used ethanol as the solvent and included TBP yielding spectra with absorbance maxim at $597 \mathrm{~nm}$. 5 standard solutions varying from 2 to $14 \mathrm{ppm}$ of U(VI) ion were prepared in the presence of $1.52 \times 10^{-3} \mathrm{M} \mathrm{CAS}, 3.2 \times 10^{-2} \mathrm{ST}$ and $0.92 \mathrm{M}$ TBP in ethanolwater $(75: 25, \mathrm{v} / \mathrm{v})$ buffered to $\mathrm{pH} 5$ with $\mathrm{pH} 3.2$ acetic acid-sodium acetate buffer. Absorbances were measured at the $\lambda_{\max }$ of $597 \mathrm{~nm}$ and slight variations in baseline were corrected by subtracting the absorbances observed at $800 \mathrm{~nm}$. Linear least squares regression analysis of the data for the dye complex method yielded the following: absorbance at $597-800 \mathrm{~nm}=0.115\left[\mathrm{U}_{\mathrm{ppm}}\right]-0.074$ (S.D. of the slope $=0.004 ;$ S.D. of the intercept $\left.=0.039 ; r^{2}=0,991\right)$ (Figure 5). Beer's law is obeyed over less than an order of magnitude which yielded a significant negative intercept when attempting to apply a linear relationship. The molar absorptivity of the U(VI).TBP.CAS.ST complex at $\lambda_{\max }=597 \mathrm{~nm}$ is $2.8 \times 10^{-4} 1 \mathrm{~mol}^{-1} \mathrm{~cm}^{-1}$.

Compare to U(VI).TBP.CAS.ST method, U(VI).FOD method does not require any post extraction reagents for UV detection and it is more sensitive with 2 orders of magnitude. 
4.2 The effects of the solid matrices on achievable uranium recoveries by liquid extraction

Average $\%$ recoveries for triplicate extractions of the U(VI) ion from the different matrices studies using various ethanol solvents are summarized in Table 3 (Details of 5 different modifiers used are given in the experimental part). It is obvious that the matrix has a considerable role in the amount of uranium which can be recovered using a particular solvent. For example, uranium was quantitatively recovered for polypropylene/polyester fibers using ethanol alone; whereas, acidified ethanol was required to quantitatively recover the same uranium concentration from glass wool as seen in Figure 6. For the cotton matrix, $0.1 \mathrm{M}$ FOD in ethanol was required to quantitatively recover the uranium; whereas, the maximum recovery from Kaolin packing was only $80 \%$. Without the chelating agent, FOD, no uranium was recovered from the Kaolin. The matrix effect on the recovery of uranium is probably caused by a different affinity of uranium for different matrices and/or different surface area of these matrices for uranium.

It is apparent that the interactions among these matrices with U(VI) ion are Kaolin $>$ cotton > glass wool > polypropylene/polyester. 


\begin{tabular}{|c|c|c|c|c|}
\hline Solvent & $\begin{array}{c}\text { Polypropylene } \\
\text { /polyester }\end{array}$ & Glasswool & Cotton & Kaolin \\
\hline $100 \%$ ethanol & $95.2(5.4)$ & $62.7(10.0)$ & $76.8(1.5)$ & 0 \\
\hline 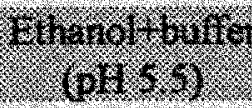 & & $90.1 .(0.5)$ & $36:(3), 2)$ & \\
\hline $\begin{array}{l}\text { Ethanol+buffer } \\
+\mathrm{TBP}(\mathrm{pH})\end{array}$ & $89.3(8.0)$ & $94.1(3.4)$ & $46.2(4.1)$ & 0 \\
\hline Etiranol r rou & 1068 (5. & $979(1.7)$ & $103(2,(2)$ & $80.8(0.1)$ \\
\hline $\begin{array}{c}\text { Ethanol+FOD } \\
+\mathrm{TBP}\end{array}$ & $102.5(1.2)$ & $101.1(5.5)$ & $97.4(4.5)$ & $81.3(2.9)$ \\
\hline
\end{tabular}

Table 3. \% Recovery of U(VI) ions (S.D.) from different matrices using different liquid solvents by stirring extraction 


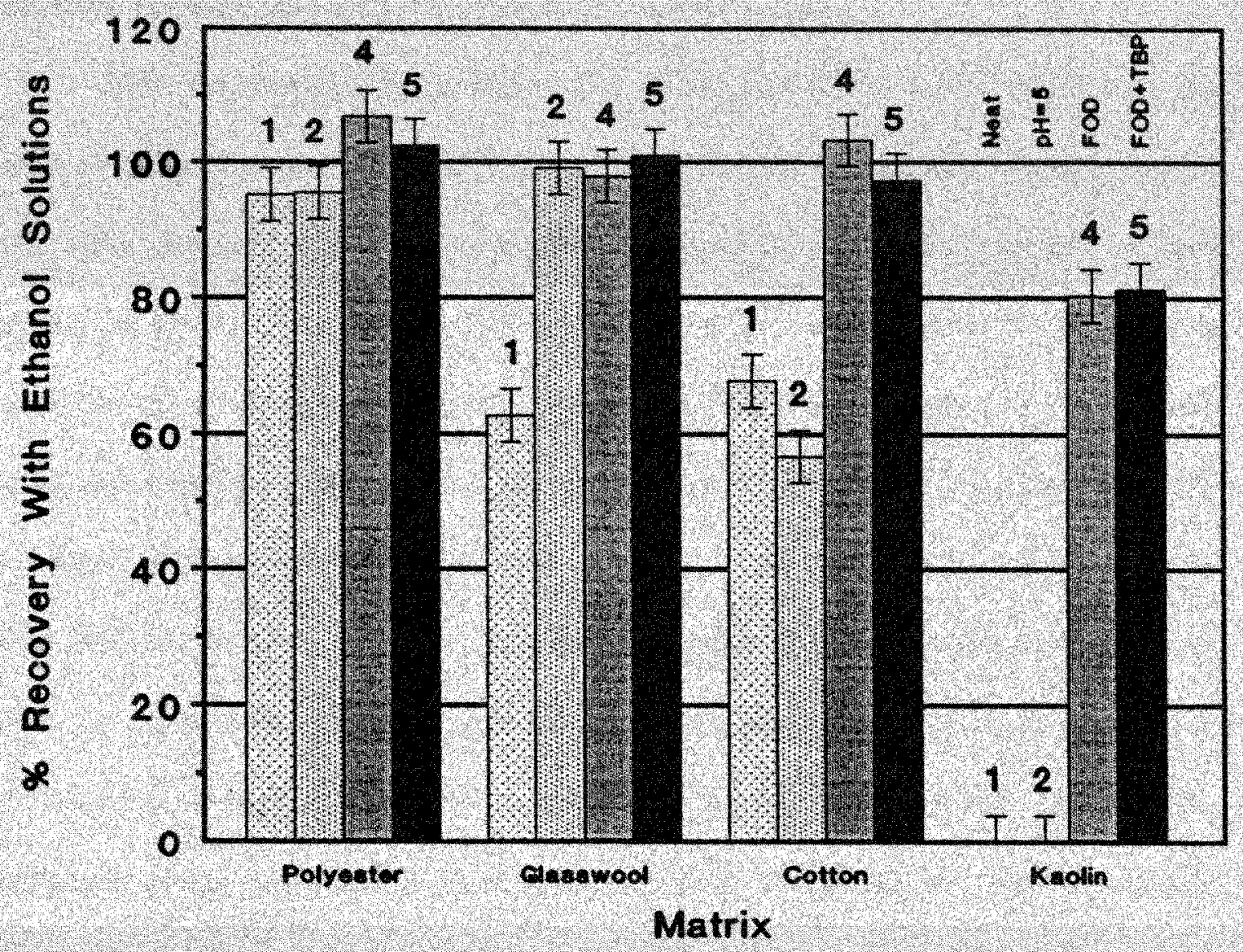

Figure 6. Recovery of U(VI) ions from different matrices using different ethanol solutions 
4.3. SFE with chelating agent, a better and more efficient method for extraction of uranyl ions than liquid extraction

Average \% recoveries for triplicate extractions of the U(VI) ion from Kaolin using different supercritical fluid $\mathrm{CO}_{2}$ modifiers is summarized in Table 4 (Details of the 6 different modifiers used are given in the experimental section).

SFE was attempted in the hopes of increasing recoveries, as well as reducing the analysis time and minimizing the amount of solvent needed. Interestingly, whereas ethanol and TBP modifiers resulted in negligible recoveries of $U(V I)$, they appear to have synergistic effects on the recovery of U(VI) when used in combination with FOD. FOD as a modifier alone yielded an average recovery of $46.6 \%$, which increased to $75.7 \%$ when combined with TBP. Surprisingly, the recoveries of U(VI) were even higher for FOD combined with ethanol $(82.2 \%)$, as seen in Figure 7. As described before, recovery of analytes relies mostly on solubility, the diffusion coefficient of the analytes in a solvent or fluid, and extractibility of the target analytes in supercritical fluid. While high solubility of the analytes in supercritical fluid is a fundamental factor to achieve high recovery, the diffusivity of the analytes, and the ability of the supercritical fluid to overcome matrixanalyte interactions, as well as the extractability of analytes in the fluid are other critical factors. The U.FOD complex, the analyte of interest, is presumably more soluble in supercritical ethanol- $\mathrm{CO}_{2}$ than in pure supercritical $\mathrm{CO}_{2}$ or probably has higher diffusion coefficient in and stronger affinity with supercritical ethanol- $\mathrm{CO}_{2}$. The highest average recoveries $(93.1 \%)$ were observed when all three modifiers were used together, $0.1 \mathrm{M}$ $\mathrm{FOD}+0.1 \mathrm{M}$ TBP in ethanol- $\mathrm{CO}_{2}(5.6 \%, \mathrm{v} / \mathrm{v})$. 


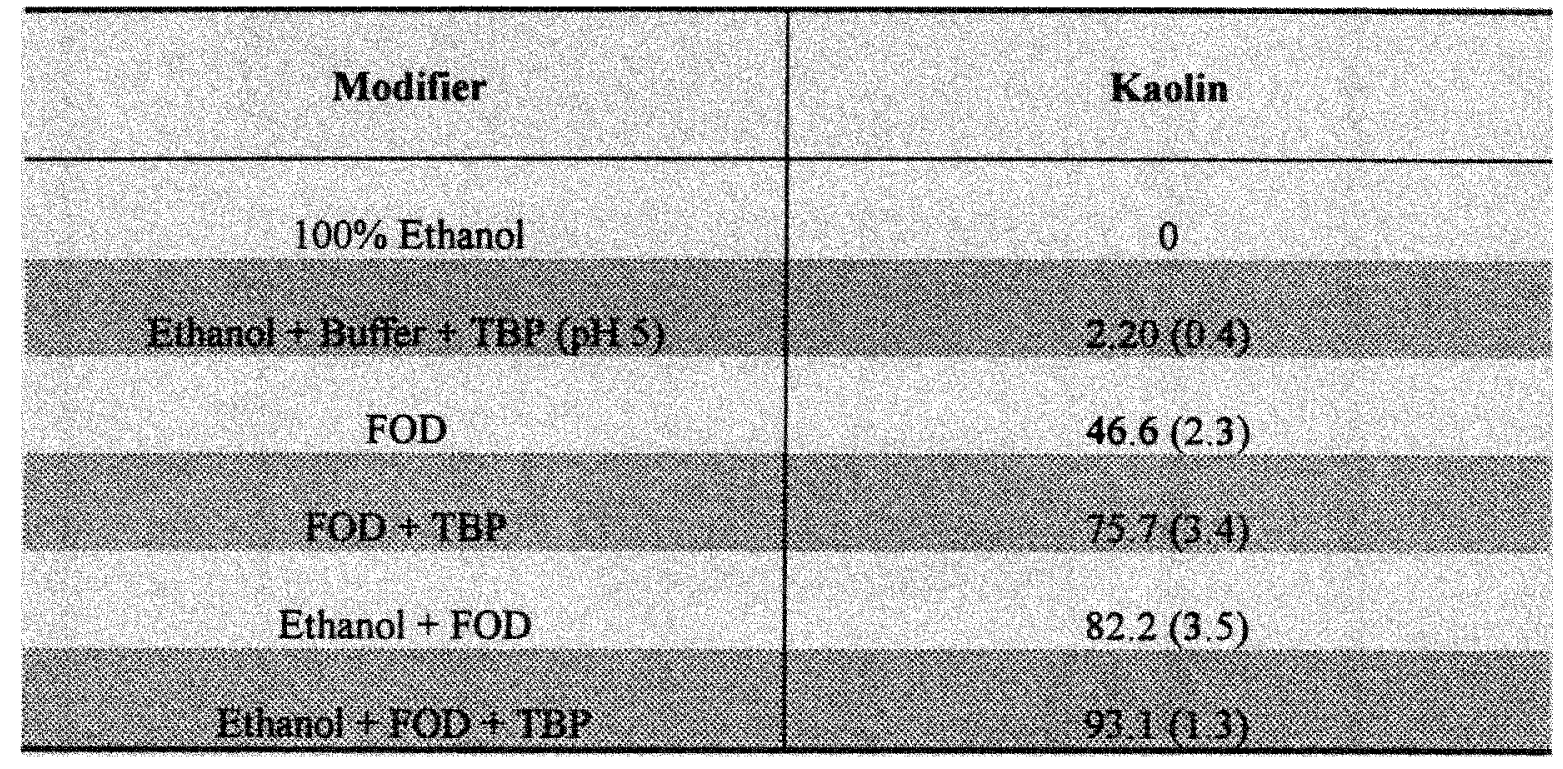

Table 4. \% Recovery of U(VI) ions (S.D.) with Kaolin using different modifiers by SFE 


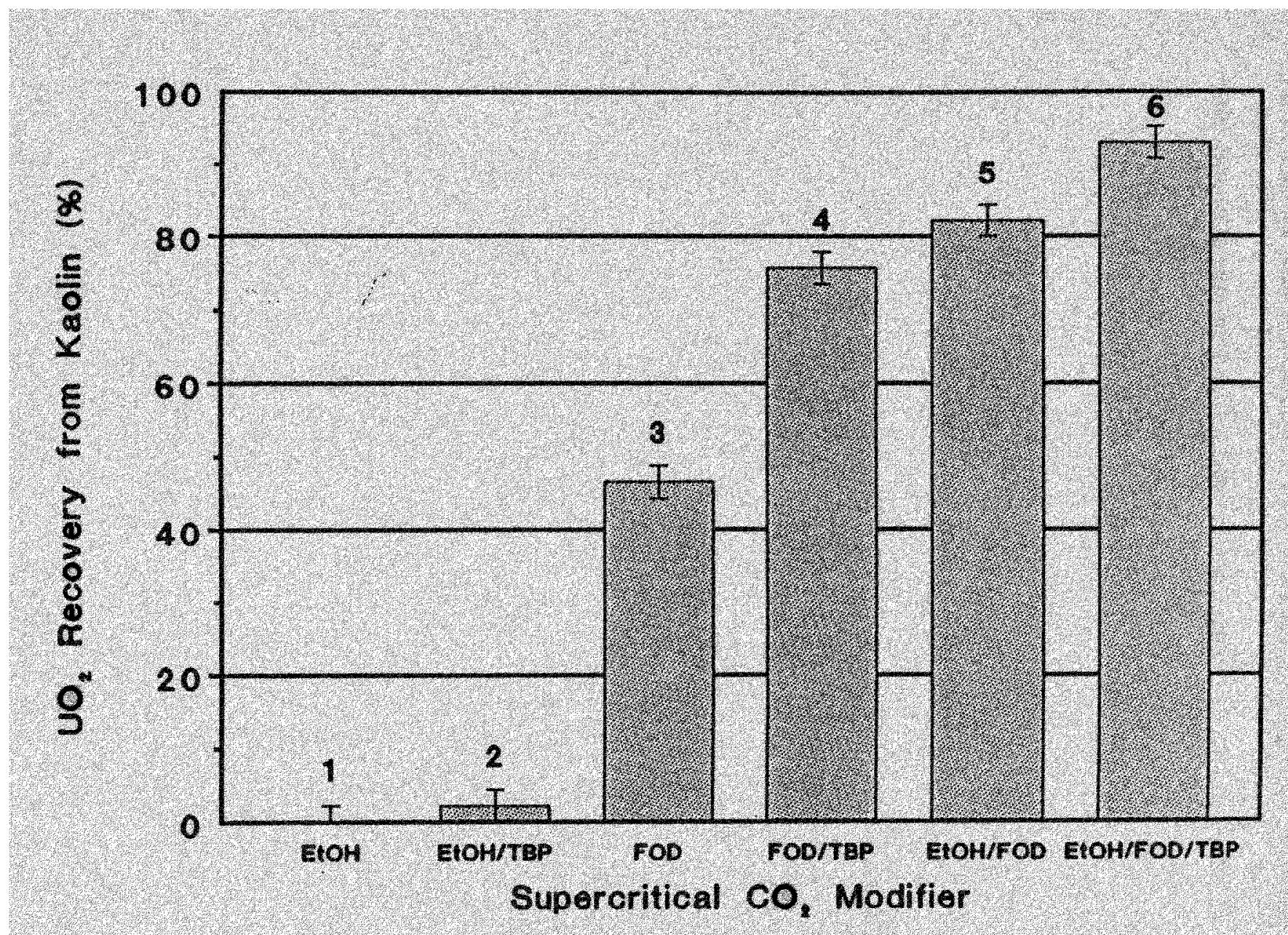

Figure 7. Recovery of U(VI) ions from Kaolin using different supercritical $\mathrm{CO}_{2}$ modifiers 
Compared to liquid extraction, the SFE method described here yields higher recoveries in less than half the time with equal or greater precision and a significant reduction in the amount of organic solvents used. 


\section{CONCLUSION}

Determination of $\mathrm{U}(\mathrm{VI})$ ions using chelation agent FOD makes direct UV monitoring and, therefore, in situ quantitation, of the amount of uranium extracted feasible with commercially available high-pressure UV view cells. The type of solid matrix is shown to dictate the achievable uranium recoveries. The extraction of U(VI) by supercritical $\mathrm{CO}_{2}$, modified by FOD, TBP and ethanol, is better than that by liquid extraction. This rapid and efficient chelation-supercritical fluid extraction approach may have significant application for analysis and treatment for real uranium-contaminated environmental samples. 


\section{SECTION B}

\section{INTRODUCTION}

\subsection{Speciation of lipids in geological solids}

Lipids in environmental samples are organism-produced substances such as fats from animals, waxes from higher plants and planktonic organic matter. They are commonly found in recent and ancient sediments and are important contributors to the formation of petroleum and natural gas. Many studies on the evolution of lipids from the time of deposition to the formation of petroleum have been reported, and the evolution of lipids has been found to be useful as a molecular indicator for petroleum exploration purposes (Tissot and Welte, 1984). Therefore, studies concerning the speciation of lipids in sediments are of great interest in organic geochemistry.

Speciation of lipids is the way these compounds associate with the sediment matrix on a molecular level. A thorough understanding of the speciation of lipids in sediments can greatly help environmental chemists to accurately evaluate the fate of organic pollutants in the environment and aid organic geochemists in petroleum exploration.

It is believed that lipids are primarily associated with the bulk organic matter (OM) in sediments. Therefore, it is likely that the speciation of lipids is strongly dependent on the geochemical transformation of $\mathrm{OM}$ in sediments. During the burial of recent sediments, there are four zones of geochemical transformation of OM: diagenesis, catagenesis, metagenesis and metamorphism (Tissot and Welte, 1984). During diagenesis, 
$\mathrm{OM}$ undergoes a variety of chemical and physical changes induced by microbial activity (biochemical degradation), followed by polycondensation and insolubilization under mild increase of temperature and pressure. The whole diagenetic process leads $O M$ in sediments from biogenic polymers (biopolymers) to geopolymers, new polycondensed structures precursing kerogen, through fractionation, partial destruction and rearrangement of the building blocks of these macromolecules (Tissot and Welte, 1984). In catagenesis, kerogen produced at the end stage of diagenesis is influenced by a considerable increase in temperature and pressure. Thermal decomposition, such as massive bond cleavage of kerogen, results in the generation of hydrocarbons in the form of petroleum and natural gas. Metagenesis and metamorphism are the last two stages of the evolution of $\mathrm{OM}$. In those two stages, the temperature and pressure reach very high values, and the residual kerogen is converted to graphic carbon releasing methane (Tissot and Welte, 1984).

It is widely accepted that lipids are associated with $\mathrm{OM}$ in sediments through partitioning, adsorption and binding processes. The lipids are therefore classified into 'free' and 'bound' categories. However, recent studies have suggested other types of speciation, such as 'trapping', which is neither 'free' nor 'bound' but 'encapsulating' or 'including' of lipids into the porous micro environment of OM (Jaffé and Gardinali, 1990). Jaffé and coworkers have indicated that the partitioning and binding processes may be the initial pathways for lipids to become associated with OM. During the deposition of OM with which lipids interact, due to macromolecule changes of the OM in sediments (during diagenesis and catagenesis), some lipids originally partitioned on or bound to OM may 
become 'trapped' in internal voids of polymeric structures of $\mathrm{OM}$ in sediments (see Figure 8 and 9), and as such preserved from further degradation.

"Biological markers (biomarkers) are those lipids detected in the geosphere, whose basic skeleton suggests an unambiguous link with a known contemporary natural product" (Mackenzie, 1984). Over the years, biomarkers have been used for a great variety of speciation studies by geochemists. The four zones of geochemical transformation mentioned before have certainly influenced lipid biomarkers deposited in sediments. During the stage of diagenesis and catagenesis, the basic carbon skeletons of biomarkers have managed to survive with only minor alterations. The major chemical transitions of biomarkers are defunctionalization, reduction, structural rearrangements (isomerization), and aromatization. These molecular changes have been successfully applied in the assessment of diagenetic changes and thermal maturation of biomarkers and $\mathrm{OM}$ in general. The capability of survival of the carbon skeleton and the molecular changes in the molecular structure (e.g. isomerization) make biomarkers important tools for geochemical studies. Since 'trapped' biomarkers may be sterically hindered from isomerizing (Jaffé and Gardinali, 1990), and therefore may present a different molecular distribution compared to the 'free' biomarkers, they can be used in the assessment of speciation of organic molecules in geological samples. 


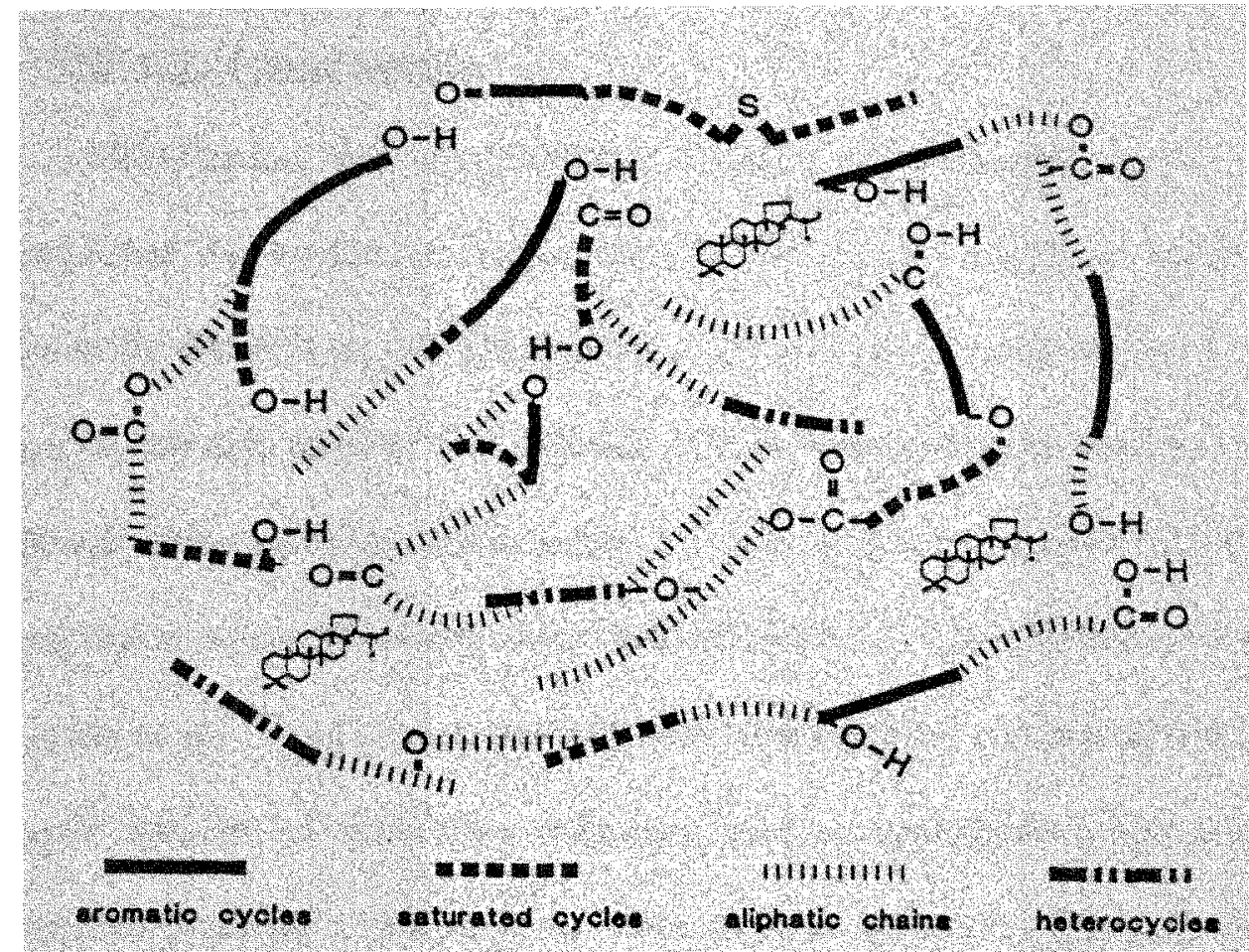

Figure 8. Hypothetical structure of sedimentary organic matter with 'trapped' lipids $[17 \alpha(\mathrm{H}), 21 \beta(\mathrm{H})$-hopane]

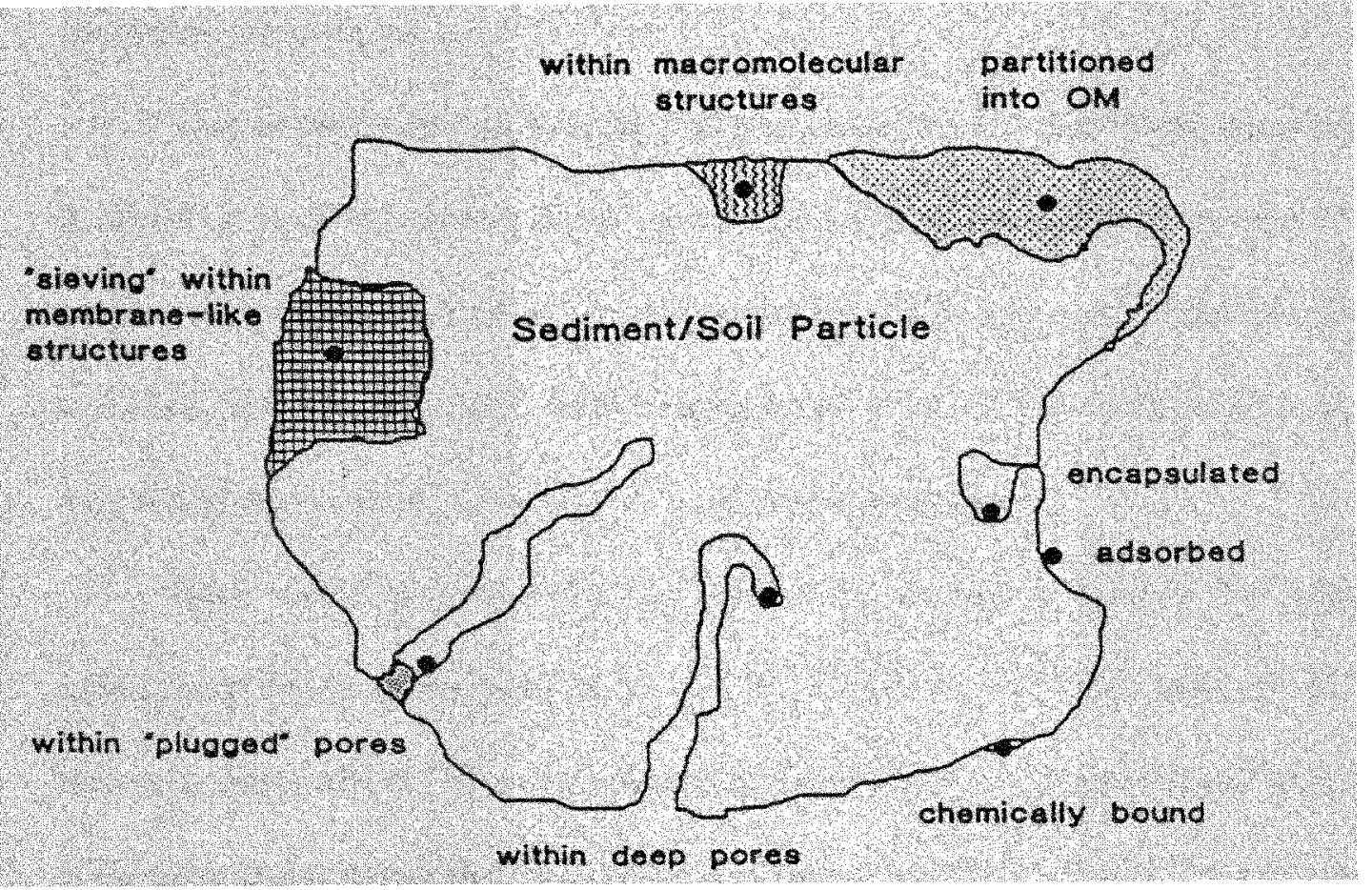

Figure 9. Hypothetical speciation of lipids in sediments 


\subsection{SFE of geological samples}

Identification and qualification of lipids in geological solids are usually accomplished by solvent extraction such as Soxhlet extraction or thermodesorption followed by GC-FID or GC-MS analysis. However, it is believed that while Soxhlet extraction can only recover 'free' fraction of lipids from sediments and has all drawbacks of solvent extraction mentioned in section 1.2., thermodesorption apparently discriminates against higher molecular weight compounds (Monin et al., 1987; Hopfgartner et al., 1990; Greibrokk et al., 1992). A few attempts have been made for the recovery of 'bound' and 'trapped' fractions of lipids from sediments, such as saponification and other chemical degradation processes (Albaiges et al., 1984; Lajat et al., 1990). However there are still common disadvantages of such extraction methods, especially, the harsh chemical conditions are involved.

Due to the unique physicochemical characteristics of supercritical fluids mentioned in section 1.1., SFE has been increasingly accepted as an alternative to the use of Soxhlet extraction and thermodesorption for extracting lipids from geological sediments (Monin et al., 1988; Kramer and Levy, 1989; Hopfgartner et al., 1990; Greibrokk et al., 1992; Ashraf-Khorassani et al., 1992; Furton et al., 1994 and others).

Early SFEs of sediments were performed by using toluene and pentane as supercritical fluids (Whitehead et al., 1975; Barlte et al. 1979; Smith et al., 1983). However, supercritical $\mathrm{CO}_{2}$ soon became the most widely used supercritical fluid because of the advantages mentioned in section 1.1.. Pure supercritical $\mathrm{CO}_{2}$ at 'normal' extraction conditions, e.g. 5000 psi and $50^{\circ} \mathrm{C}-80^{\circ} \mathrm{C}$, was used to extract biomarkers from sediments 
and the results obtained for hopanes and steranes were in good agreement with those of solvent extraction, but with 45 mins of SFE vs. several hours of liquid extraction (Hopfgartner et al., 1990). Alternatively, small amounts of 2-propanol mixed with $\mathrm{CO}_{2}$ as a modified supercritical $\mathrm{CO}_{2}$ were used to extract petroleum source rocks to increase extraction yields (Greibrokk et al., 1992). However, because of the complex nature of the speciation of lipids with $\mathrm{OM}$ in sediments, 'normal' supercritical $\mathrm{CO}_{2}$ extraction conditions apparently have insufficient ability to extract those lipids having stronger interaction with OM in sediments, such as those derived from 'binding' to and 'trapping' within the matrix. The recovery of lipids under 'normal' supercritical $\mathrm{CO}_{2}$ extraction condition is, therefore, only similar to that from solvent extraction. Modified supercritical $\mathrm{CO}_{2}$ extractions have yielded higher recoveries, possibly due to higher affinity of modified fluid for the matrix associated lipids or the removal/rearrangement of more polar structures within the matrix or pore environments. However, it is still unlikely that the modified $\mathrm{CO}_{2}$ can efficiently approach those lipids 'trapped' in the internal voids of polymeric structures of $O M$ in sediments.

Recently, Furton et al. (1994) and Jaffé et al. (1996) have reported the use of high temperature SFE (HT-SFE) for recovery of hydrophobic organic compounds in geological samples. They have found that HT-SFE $\left(350^{\circ} \mathrm{C}\right)$ showed much higher recoveries, up to $200 \%$, when compared with Soxhlet extractions ( $24 \mathrm{hr}$.) using methylene chloride (Furton et al., 1994). These authors have suggested that higher extraction temperatures, which are impossible to achieve for standard solvent extraction, are likely to facilitate release of those lipids with stronger interaction with matrix (such as 'trapped' lipids), due to 
thermally induced structural rearrangement of macromolecular $\mathrm{OM}$ of sediments, and increased desorption kinetics (Furton et al., 1994). In addition, the supercritical fluid has better access to the 'trapped' lipids, compared to solvents, because of its ability to penetrate into the opening porous matrix (due to thermally induced structural rearrangement of macromolecular $\mathrm{OM}$ of sediments). With the help of high diffusion coefficient of lipids in supercritical fluid, 'trapped' lipids can be released efficiently during high temperature experiments, possibly aided by thermal desorption, . During these earlier studies, however, only pyrolysis derived hydrocarbons such as alkanes, naphthalenes and phenanthrenes were studied. A more detailed study of biomarkers, and changes in their fingerprint/molecular distribution with increasing extraction temperature is needed to better understand the application of stepwise HT-SFE as a technique for speciation studies. 


\section{OBJECTIVES}

There were two major objectives for this work:

1. To better understand the speciation of lipids in geological samples by means of evaluating the molecular maturity parameters of pentacyclic triterpenoids (hopanes), and aromatic steranes recovered from stepwise HT-SFE.

2. To evaluate the effect of stepwise HT-SFE on the relative recovery of nalkanes, polyaromatic hydrocarbons (naphthalene, methylated naphthalenes, phenanthrene, methylated phenanthrenes, anthracene and methylated anthrecenes) and biomarkers from sediments by comparison with the recovery of those compounds form Soxhlet extraction and thermodesorption. 


\section{EXPERIMENTAL}

\subsection{Materials}

Two shale samples were analyzed: Posidonia shale [Germany; OM type I, Vitrinite reflectance: $0.36 \%$ Ro, TOC: 10.27 (\%wt.)] and Kupferschiefer shale [Germany; OM type II, Vitrinite reflectance: $0.43 \%$ Ro, TOC: $3.09(\%$ wt.)]. Both samples were kindly supplied by Dr. Christian Eckardt from Bristol University, UK.

SFC/SFE grade carbon dioxide was purchased from Air Products and Chemicals (Allentown, PA) and used for all SFE experiments. UHP/zero grade nitrogen gas used for concentrating the extracts and for the thermodesorption experiment was also obtained from Air Products and Chemicals. All solvents used were optima grade and were purchased from Fisher Scientific (Orlando, FL). 


\subsection{Instrumentation and extraction}

\subsubsection{Supercritical fluid extraction}

The same microprocessor-controlled syringe pump as described in section 3.2.2. was used for all supercritical fluid extractions. However, the SFX-240 extractor was replaced by a Varian $3700 \mathrm{GC}$ oven (max. temperature limit at $400^{\circ} \mathrm{C}$ ), in order to obtain higher temperatures. A $15 \mathrm{~cm} \times 1 \mathrm{~cm}$ i.d. (1/2 in. o.d.) custom-built high pressure stainless steel column (Keystone Scientific, Inc., Bellefonte, PA) was used as the extraction cell. Two $2 \mu \mathrm{m}$-sieving pore stainless steel frits (Keystone Scientific) were placed at two ends of the stainless steel column described above to prevent shall samples from being flushed out. A $1 \mathrm{~m}$ coil of $1.6 \mathrm{~mm}$ o.d. (1/16 inch $\times 0.76 \mathrm{~mm}$ i.d. stainless steel tubing) (Upchurch Scientific, Inc., Oak Harbon, WA) was placed in the GC oven prior to the extraction cell as pre-equilibrium zone to pre-heat the $\mathrm{CO}_{2}$. A needle valve (Scientific System, Inc., State College, PA), heated to $250^{\circ} \mathrm{C}$ with the same heating tape described in section 3.2 .2 . to prevent it from plugging, was used to control the flow. A glass vial containing about $5 \mathrm{ml}$ methylene chloride with constant adding up to maintain the solvent volume was used for fluid decompression and analytes collection through a $9 \mathrm{~cm} \times 50 \mu \mathrm{m}$ i.d. fused silica capillary linear restrictor (Furton et al., 1994).

The schematic diagram of the SFE system is shown in Figure 10. $3 \mathrm{~g}$ sample of Posidonia or Kupferschiefer shale was placed in the extraction cell and extracted by supercritical $\mathrm{CO}_{2}$ at $5000 \mathrm{psi}$ and at a consecutive stepwise temperature profile described below. The extraction temperature was controlled so that the sample was extracted at $50^{\circ} \mathrm{C}, 150^{\circ} \mathrm{C}, 250^{\circ} \mathrm{C}$ and $350^{\circ} \mathrm{C}$, each for 30 mins followed by a lower temperature step at 


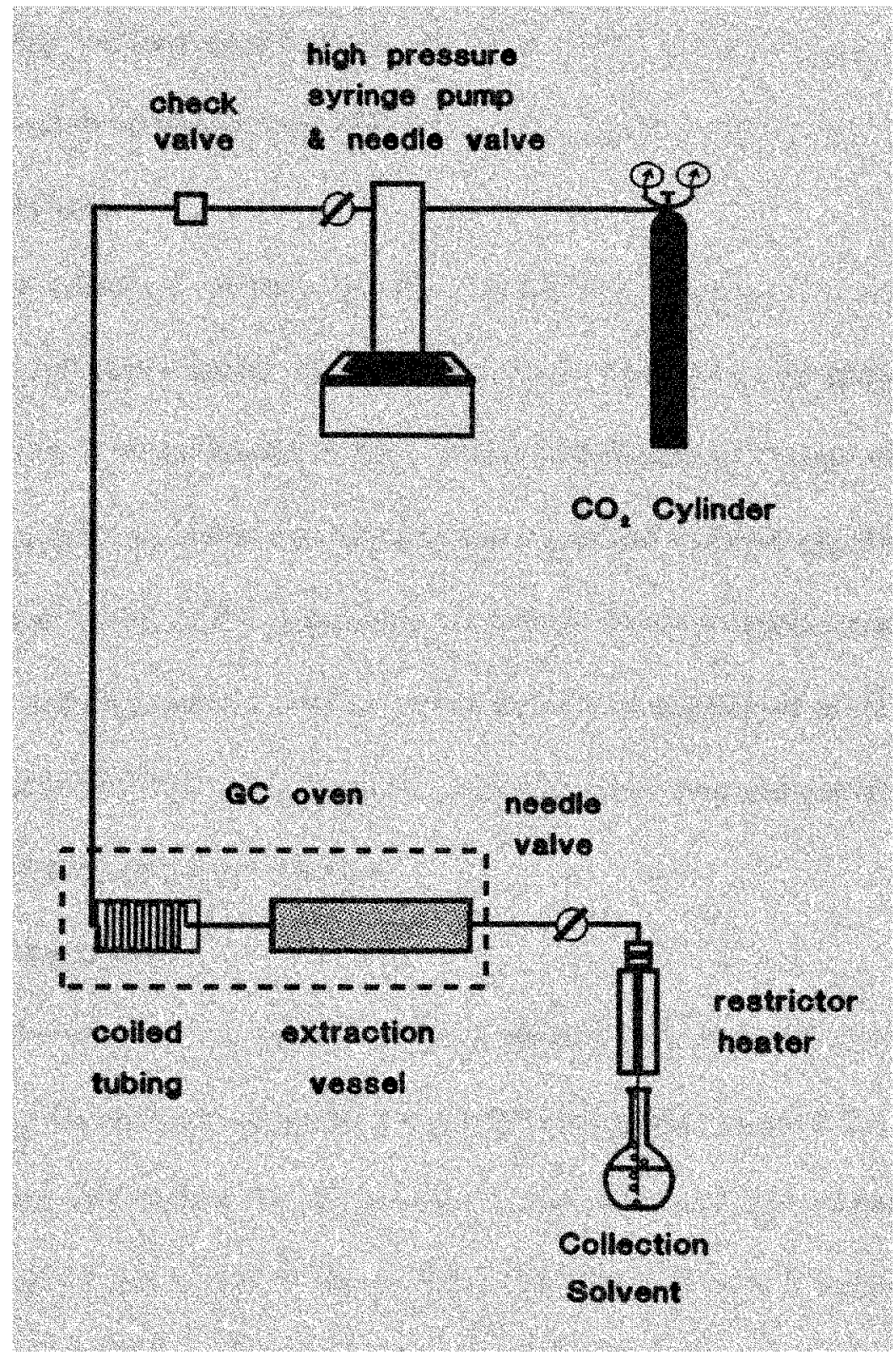

Figure 10. The schematic diagram of HT-SFE system 
$50^{\circ} \mathrm{C}$ after each extraction temperature (also see Furton et al., 1994). The extraction time for each step, including the time needed for heating up and cooling down to $50^{\circ} \mathrm{C}$ was 60 mins. Therefore, the total extraction time for each sample, with 4 consecutive steps, was 4 hours. The stepwise temperature profile for SFE is shown in Figure 11. The flow rate used was $2.0 \mathrm{ml} / \mathrm{min}$.

Four fractions of extracts at every extraction temperature were individually collected. A $1899 \mathrm{ppm}$ squalane standard solution was prepared by weighing $0.0959 \mathrm{~g}$ of squalane $(99 \%$ ) in a $50 \mathrm{ml}$ volumetric flask, mixing and diluting to volume with methylene chloride. $10 \mu \mathrm{l}$ and $5 \mu \mathrm{l}$ of this standard solution was added to Posidonia shale extracts at $50^{\circ} \mathrm{C}, 350^{\circ} \mathrm{C}$ and $150^{\circ} \mathrm{C}, 250^{\circ} \mathrm{C}$ respectively as internal standard before concentrating. 5 $\mu l$ of another squalane internal standard solution with concentration of $1860 \mathrm{ppm}$ was used for all Kupferschiefer shale extracts. Extracts were then concentrated by gentle nitrogen gas blow down prior to analysis.

\subsubsection{Thermodesorption}

Thermodesorption was performed for Posidonia shale only. $3 \mathrm{~g}$ of sample was extracted using the identical apparatus and temperature profile as used for SFE, except that the $\mathrm{CO}_{2}$ was replaced by $\mathrm{N}_{2}$ gas (ca. 50 psi) with a flow of $900 \mathrm{ml} / \mathrm{min}$ in order to contain a similar volume of gas $\mathrm{N}_{2}$ to the liquid $\mathrm{CO}_{2}$ with a flow of $2 \mathrm{ml} / \mathrm{min}$. The preequilibrium coil of stainless steel tube was replaced by the same tube but with only $30 \mathrm{~cm}$ of length. A $530 \mu \mathrm{m}$ i.d. uncoated fused silica capillary restrictor (Alltech Associates, Inc., Deerfield, $\mathrm{IL}$ ) with a length of $9 \mathrm{~cm}$ was used as the outlet restrictor. Four fraction of extracts were collected and concentrated in the same manner as used for the extracts 


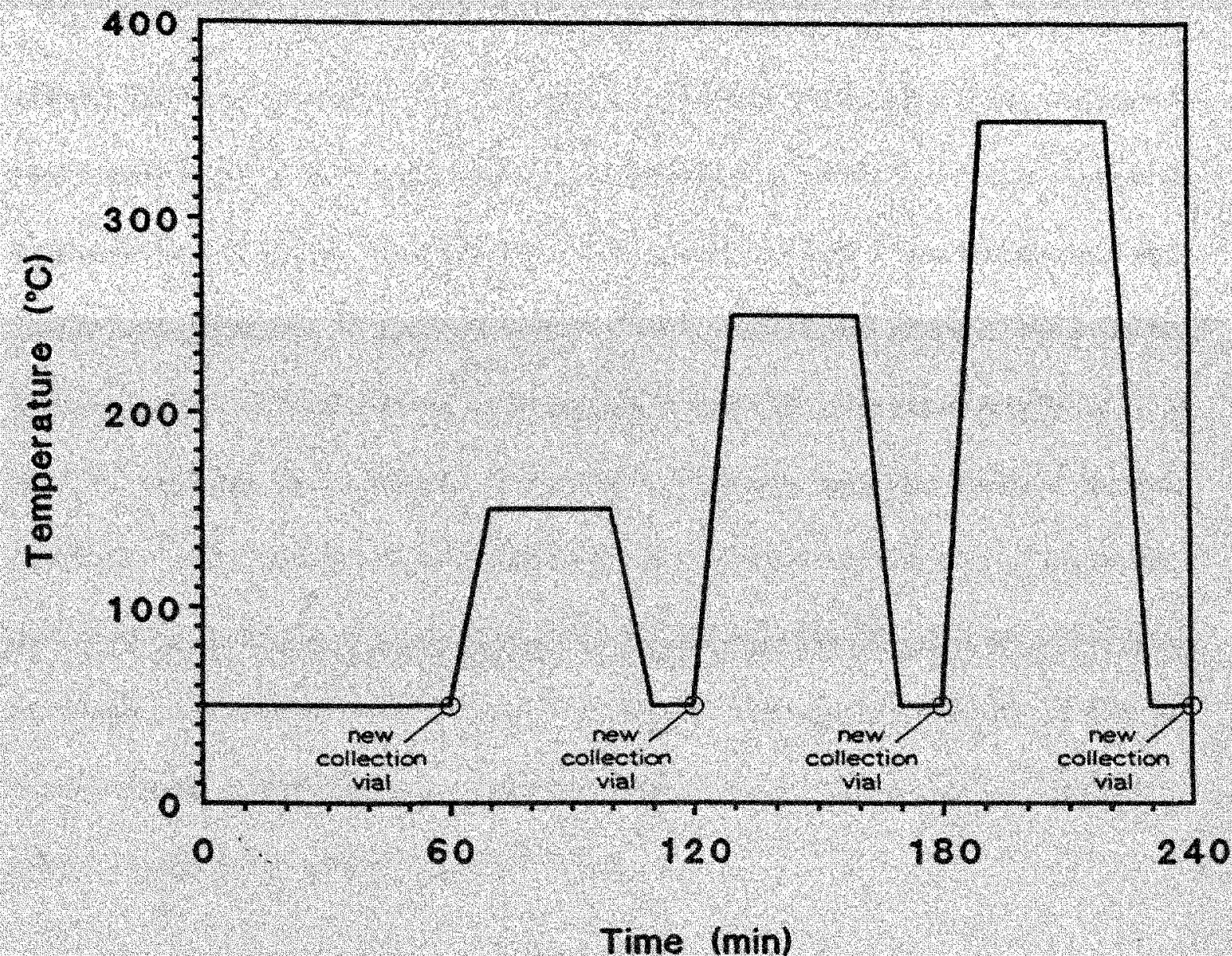

Figure 11. The stepwise temperature profile for HT-SFE 
from SFE. $5 \mu$ l of $1899 \mathrm{ppm}$ squalane standard solution was added to the extracts prior to concentrating as internal standard for quantitation.

\subsubsection{Soxhlet extraction}

All Soxhlet extractions were performed with approximate $150 \mathrm{ml}$ of methylene chloride for $48 \mathrm{~h}$ at ca. $50^{\circ} \mathrm{C} .10 \mathrm{~g}$ samples of Posidonia and Kupferschiefer shale were used. After 48 hours of extraction, $10 \mu \mathrm{l}$ of $1860 \mathrm{ppm}$ squalane internal standard solution was added to each extract. Extracts were then concentrated with a rotary evaporator and further concentrated by $\mathrm{N}_{2}$ gas blow down. Prior to analysis, the aliphatic and aromatic hydrocarbons in the total extracts were separated by adsorption chromatography on $21 \mathrm{~g}$ of $5 \%$ activated silica column. Fractions 1 (aliphatics with the squalane internal standard), 2 and 3 (aromatics) were eluted with $60 \mathrm{ml}$ hexane, $45 \mathrm{ml}$ hexane $/ 15 \mathrm{ml}$ toluene and $30 \mathrm{ml}$ hexane $/ 30 \mathrm{ml}$ toluene respectively and collected together. The total of $180 \mathrm{ml}$ of solvents was used to ensure the analytes of interest (aliphatics, aromatics as well as internal standard) to be completely eluted out. The total extract was then concentrated by rotary evaporator and gentle $\mathrm{N}_{2}$ gas blow down. 


\subsection{Identification and quantification}

In addition to the biomarkers, mainly the hopanes and aromatic steranes, aliphatic hydrocarbons, such as n-alkanes, and acyclic isoprenoids, such as pristane and phytane; aromatic hydrocarbons, such as naphthalene and alkylnaphthalenes, phenanthrene and alkylphenanthrenes, anthracene and alkylanthracenes, were the target analytes for the project. All extracts were identified and quantified on an HP 5890 Series II GC (HewlettPackard, Palo Alto, CA) equipped with a 30m DB-5MS column (J\&W Scientific, Folsom, CA) and with an HP 5971 mass selective detector (MS) (Hewlett-Packard). The temperature programming of the $\mathrm{GC}$ for aliphatic and aromatic hydrocarbons was $1.0 \mathrm{~min}$ at $40^{\circ} \mathrm{C}$ followed by a temperature increase rate of $6.0^{\circ} \mathrm{C} / \mathrm{min}$ to $300^{\circ} \mathrm{C}$ and held isothermally for 20 mins. For biomarkers, the GC temperature was controlled at the same initial temperature and the same rate of increase as described above but with a constant temperature at $300^{\circ} \mathrm{C}$ for 30 mins. The aliphatic and aromatic hydrocarbons were analyzed by Total Ion Chromatography (TIC) and all biomarkers were analyzed by Selected Ion Monitoring (SIM). All GCMS runs were performed in the electron impact (EI) mode at an ionization energy of approximately 70 e.v. 


\section{RESULTS AND DISCUSSION}

\subsection{Speciation of lipids in geological samples}

Hopanes and aromatic steranes (mono and tri) detected in ancient sediments are believed to be derived from the diagenesis of natural product 'rigidifiers' of cell wall members (e.g. bacterio-hopanotetrol) and sterols (e.g. cholesterol) in organisms (Mackenzie 1984). As described in section 6.1., during diagenesis and catagenensis, these biomarkers undergo chemical transitions of defunctionalization, isomerization and aromatization. This process is initially induced by microorganisms and followed by temperature effects. The chemical transitions from the precursor molecules to thermally matured biomarkers (e.g. hopanes and aromatic steranes) are shown in Figures 12 and 13 Those thermal maturation processes of biomarkers are useful parameters in geochemical exploration.

As shown in Figure 12, polyhydroxybacteriohopane, one of the precursors of hopanes, is converted to the lease stable configuration of hopanes $I[17 \beta(H), 21 \beta(H)]$ by mainly microbial activity during early diagenesis. The least thermodynamically stable hopanes $[17 \beta(\mathrm{H}), 21 \beta(\mathrm{H})]$ are then isomerized to II $[17 \beta(\mathrm{H}), 21 \alpha(\mathrm{H})]$ (moretanes) and III $[17 \alpha(H), 21 \beta(H)]$ (hopanes), the most stable configuration during maturation. If $\mathrm{R}$ in

Figure $\mathrm{Ib}$ is equal or greater than $-\mathrm{CH}_{3}\left(\geq \mathrm{C}_{31}\right)$, there is a chiral center at $\mathrm{C}-22$. During maturation, the biogenic $22 \mathrm{R}$ configuration (immature stage) is converted to a $3: 2$ mixture of $22 \mathrm{~S}$ and $22 \mathrm{R}$ components. At this stage, thermodynamic equilibrium is reached and the isomerization process ends. 
<smiles>CCCC12CCCCC1CCC1C(C(C)CCC(O)C(O)C(O)CO)CCC12</smiles>

polybydroxybacteriobopanes<smiles>[R]C1CCC2C1CCC1C2CCC2C1CCC1CCCCC12C</smiles>

$\mathrm{R}=\mathrm{H}_{3} \mathrm{CH}_{3}$

la

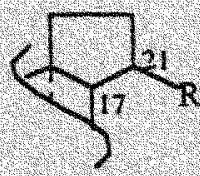

IIa

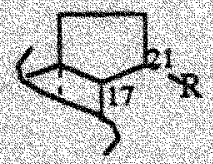

IIIa
$\mathrm{Ib}$

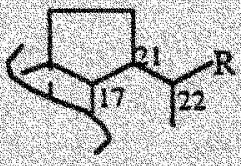

110

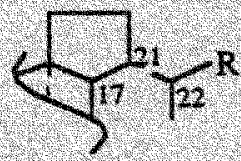

IIIb

Figure 12. Polyhydroxybacteriohopanes are the presumed presursors of the ubiquitous extended hopanes found in recent and ancient sediments and in petroleum. Stereoisomers represented by the hopane structures I-III are present during early diagenesis. Stability increases in the order I [17 $\beta(\mathrm{H})$, $21 \beta(\mathrm{H})]<\mathrm{II}[(17 \beta(\mathrm{H}), 21 \alpha(\mathrm{H})]<\mathrm{II}[(17 \alpha(\mathrm{H}), 2 \| \beta(\mathrm{H})]$. The major biological input is $\mathrm{l}$, but geological isomerization of the alkanes means that this converted by isomerization at $\mathrm{C}-17$ to mainly III with increasing maturity. $\mathrm{Ib}$, IIb and IIIb have a chiral center at $\mathrm{C}-22\left(\mathrm{R} \geq \mathrm{CH}_{3}\right)$. In immature sediments only the $22 \mathrm{R}$ configuration derived from the natural product precursors. Isomerization converts this to a 3:2 mixture of $22 \mathrm{~S}$ ad $22 \mathrm{R}$ components (Taken from Mackenzie 1984 in Advanced in Petroleum Geochemistry, Volume I, pg. 128 and pg. 131; J.Brooks and D. Welte. 1984) 


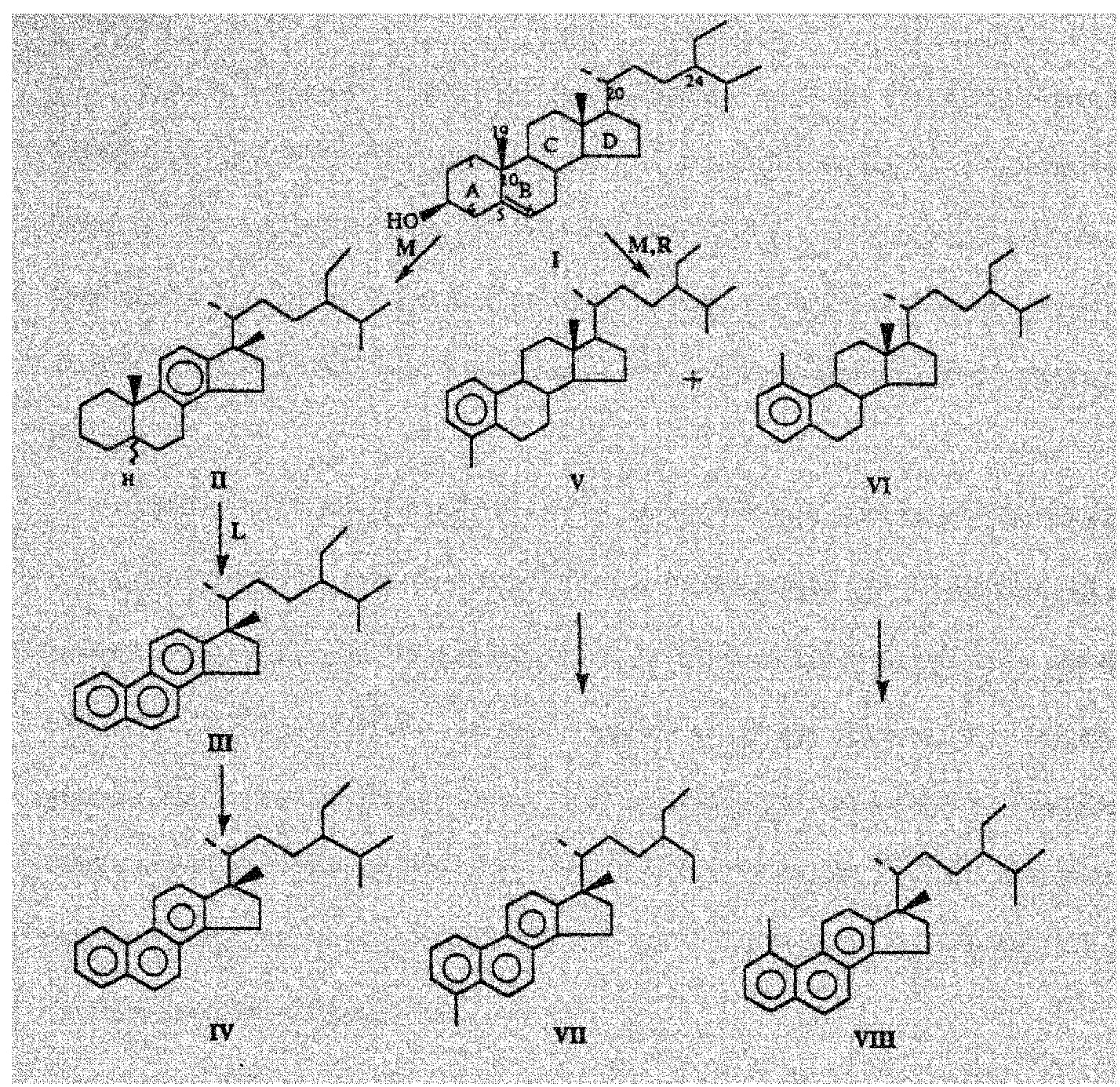

Figure 13. Simplified reaction scheme to show the conversion of a sterol, 1, to various aromatic hydrocarbons. An arrow labeled $M$ implies that reaction occurs in more than one step. One labeled $\mathbf{R}$ implies aromatization of the A ring, but with retention of the C-19 methyl group which is rearranged from C-10 to either $\mathrm{C}-1, \mathrm{C}-4$ or other positions. One labeled $\mathbf{L}$ implies aromatization of the $\mathrm{B}$ ring with the loss of the C-19 methyl group. The monoaromatic hydrocarbons II, V and VI appear during early diagenesis, but are both further aromatized to triaromatic steranes (TV, VI and VII). The C-19 methyl group is chiefly lost when the order in which the aromatization of the rings occurs is $\mathrm{C}-\mathrm{B}-\mathrm{A}$, but is retained if the order is A-B-C. The structure of III is not proven and is proposed on the basis of the GCMS results. The conversion of II and III is the basis of the GC-MS results (Taken from Mackenzie 1984 in Advanced in Petroleum Geochemistry, Volume I, pg. 128 and pg. 131; J.Brooks and D.Welte. 1984) 
For the steroidal compounds, the maturation processes are more complex. Dehydration and reduction of double bonds, structural rearrangements, configurational isomerization and aromatization are involved. The transition of a sterol (I) to various aromatic steranes shown in Figure 13 is a simplified proposed pathway of aromatization of steranes. During thermal maturation, monoaromatic steranes are converted to triaromatic steranes.

Molecular thermal maturity parameters, such as: the ratio of $22 \mathrm{~S}$ to the sum of $22 \mathrm{~S}$ and $22 R[22 S /(22 S+22 R)]$ and the ratio of $\beta \alpha$-Moretanes to $\alpha \beta$-hopanes $[\beta \alpha-$ Moretanes/ $\alpha \beta$-hopanes] for hopanes and the ratio of triaromatic steranes to the sum of triaromatic and monoaromatic steranes $[\mathrm{TA} /(\mathrm{TA}+\mathrm{MA})]$ are often used by organic geochemists for thermal maturity evaluation of the sediment, petroleum and rock samples. From the maturity conversion described before, it is obvious that with the increase of thermal maturity, the ratio of $[22 \mathrm{~S} /(22 \mathrm{~S}+22 \mathrm{R})]$, and $[\mathrm{TA} /(\mathrm{TA}+\mathrm{MA})]$ increases and that of $[\beta \alpha$-Moretanes/ $\alpha \beta$-hopanes] decreases.

Inversion of such molecular maturity parameters trends has rarely been observed in the natural environment. Jaffé and Gardinali (1990) observed a relative increase in the abundance of the thermodynamically less stable $(17 \beta, 21 \beta)$ isomers of the hopanoic acids in highly mature rock samples. Similarly, Kawamura et al. (1986) observed an increase in abundance of less mature long chain acids in the tightly bound fraction of shale samples. Both studies suggest that molecular speciation plays an important role in these 'apparent' maturity inversions. The explanation of this phenomenon is that immature biomarkers, encapsulated into the organic matrix at early stages of diagenesis, become 'trapped' in, or 
chemically bound (e.g. via sulfur bounds; Richnow et al., 1992) to the organic matrix of the sediments. At high temperature regimes, these components, which are protected from maturation processes by steric effects of the matrix, become released causing the 'apparent' maturity inversion. Based on the hypothesis described above, biomarker maturity parameters can be used to study speciation of organic compounds in sediments and rock samples. This would be particularly useful if it is assumed that 'trapped' components are released during stepwise HT-SFE experiments. Data in support of this assumption has been produced by former research activities in our laboratories by studying the pyrolysis derived hydrocarbons such as alkanes, naphthalenes and phenanthrenes (Huang, 1994; Gong, 1995; Furton et al., 1994). Based on these results, a decrease in the thermal maturity parameters $[22 \mathrm{~S} /(22 \mathrm{~S}+22 \mathrm{R}]$ and $[\mathrm{TA} / \mathrm{TA}+\mathrm{MA})]$, and a increase in $[\beta \alpha-$ Moretanes/ $\alpha \beta$-hopane]of biomarkers would be expected with increasing extraction temperature, if release of 'trapped' hydocarbons actually occurs under these conditions.

Hopanes and aromatic steranes extracted from Posidonia and Kupferschiefer shale by stepwise HT-SFE were used for molecular maturity and speciation study in this project. The ion 191, 253 and 231 (mass chromatograms) of hopanes, mono and triaromatic steranes from HT-SFE of Posidonia shale at $50^{\circ} \mathrm{C}$ fraction are shown in Figures 14,15 and 16. The peaks identified are listed in Tables 5, 6 and 7. Average recoveries of hopanes, mono and triaromatic steranes from triplicate and single stepwise HT-SFE of Posidonia and Kupferschiefer shale at each fraction $\left(50^{\circ} \mathrm{C}, 150^{\circ} \mathrm{C}, 250^{\circ} \mathrm{C}\right.$ and $\left.350^{\circ} \mathrm{C}\right)$ are summarized in Tables $8,9,10,11,12$, and 13. It is apparent that the amount of biomarkers released at each temperature is different, indicating possible differences in the speciation of these 


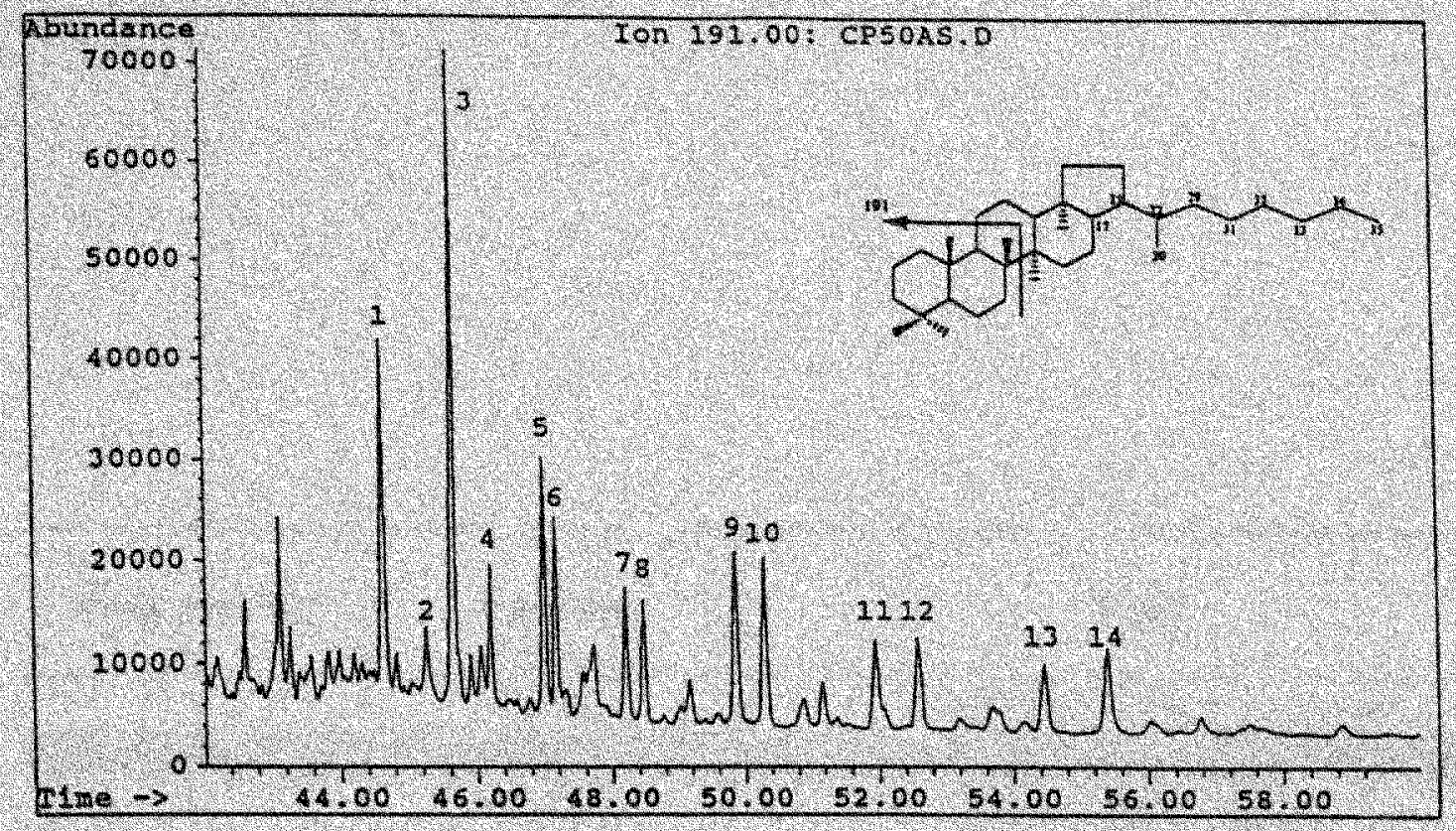

Figure 14. $\mathrm{m} / \mathrm{z}=191$ Mass chromatogram of hopanes from stepwise HT-SFE of Posidonia shale at $50^{\circ} \mathrm{C}$

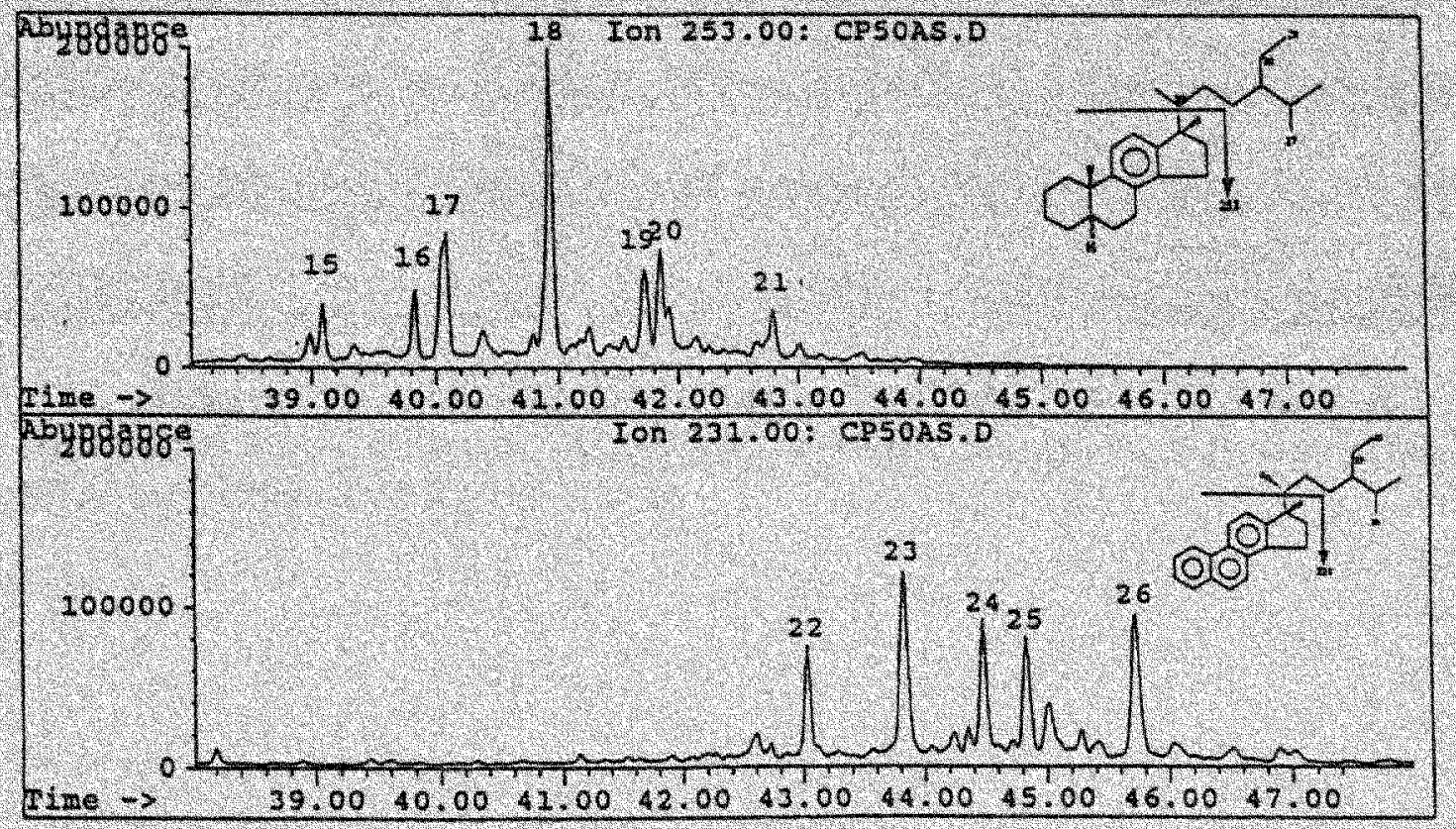

Figure 15. $\mathrm{m} / \mathrm{z}=253$ Mass chromatogram of monoaromatic steranes from stepwise HT-SFE of Posidonia shale at $50^{\circ} \mathrm{C}$

Figure 16. $\mathrm{m} / \mathrm{z}=231$ Mass chromatogram of triaromatic steranes from stepwise HT-SFE of Posidonia shale at $50^{\circ} \mathrm{C}$ 


\begin{tabular}{|c|c|c|}
\hline Peak number & Formula & Name \\
\hline 1 & $\mathrm{C}_{29} \mathrm{H}_{50}$ & $17 \alpha(\mathrm{H}), 21 \beta(\mathrm{H})-30$-norhopane \\
\hline 2. & $\mathrm{C}_{2} \mathrm{H}_{s 0}$ & $17 \beta(H), 21 \alpha(H), 30$ - norhopane (tormoretane) \\
\hline 3 & $\mathrm{C}_{30} \mathrm{H}_{52}$ & $17 \alpha(\mathrm{H}), 21 \beta(\mathrm{H})$-hopane \\
\hline 4 & $\mathrm{C}_{1} \mathrm{H}_{32}$ & $17 \mathrm{~g}(\mathrm{H}), 21 \propto(\mathrm{H})$ hopare (noretane) \\
\hline 5 & $\mathrm{C}_{31} \mathrm{H}_{54}$ & $17 \alpha(\mathrm{H}), 21 \beta(\mathrm{H})-29$-homohopane (22S) \\
\hline 6 & $\mathrm{C}_{5} \mathrm{H}_{54}$ & $17 \alpha(H), 21 B(H), 29$ homolopane $(22 R)$ \\
\hline 7 & $\mathrm{C}_{32} \mathrm{H}_{56}$ & $17 \alpha(H), 21 \beta(H)-29$-bishopane (22S) \\
\hline 8. & $\mathrm{C}_{32} \mathrm{H}_{36}$ & $170(11), 21 p(H)-29$ bishopane $(22 R)$ \\
\hline 9 & $\mathrm{C}_{33} \mathrm{H}_{58}$ & $17 \alpha(\mathrm{H}), 21 \beta(\mathrm{H})$-29-trishopane $(22 \mathrm{~S})$ \\
\hline 10 & $\mathrm{C}_{33} \mathrm{H}_{48}$ & $17 a(H), 218(H), 29$-rishopane $(22 R)$ \\
\hline 11 & $\mathrm{C}_{34} \mathrm{H}_{60}$ & $17 \alpha(\mathrm{H}), 21 \beta(\mathrm{H})$-29-tetrakishopane (22S) \\
\hline 12 & $\mathrm{C}_{71} \mathrm{I}_{60}$ & $17 a(H), 21 B(H), 29$-tetrakishopane $(22 R)$ \\
\hline 13 & $\mathrm{C}_{35} \mathrm{H}_{62}$ & $17 \alpha(\mathrm{H}), 21 \beta(\mathrm{H})$-29-pentakishopane (22S) \\
\hline 14 & $\mathrm{C}_{3} \mathrm{H}_{62}$ & $17 a(H), 21 \beta(H)-29$-pentakishopane $(22 \mathrm{R})$ \\
\hline
\end{tabular}

Table 5. The peaks identified for $\mathrm{m} / \mathrm{z}=191$ (hopanes) mass chromatogram from stepwise HT-SFE of Posidonia shale at $50^{\circ} \mathrm{C}$ (The name of peaks: The Biomarker Guide, Peters and Molddowan, 1993. pg.: 77) 


\begin{tabular}{|c|c|c|}
\hline Peak number & Formula & Name \\
\hline 15 & $\mathrm{C}_{27} \mathrm{H}_{42}$ & $5 \beta(H)$ cholestane $(20 S)$ \\
\hline 16 & $\mathrm{C}_{27} \mathrm{H}_{22}$ & $5 \rho(H)$ cholestane $(20 \mathrm{R})$ \\
\hline \multirow[t]{2}{*}{17} & $\mathrm{C}_{27} \mathrm{H}_{42}$ & $5 \alpha(H)$ cholestane $(20 S)$ \\
\hline & $\mathrm{C}_{2 \mathrm{~B}} \mathrm{H}_{4}$ & $5 B(11)$ ergostane $(20 S)$. \\
\hline \multirow[t]{4}{*}{18} & $\mathrm{C}_{27} \mathrm{H}_{42}$ & $5 \alpha(\mathrm{H})$ cholestane $(20 \mathrm{R})$ \\
\hline & $\mathrm{C}_{28} \mathrm{H}_{\mathrm{ir}}$ & $5 a(1)$ ergostane $(20 \mathrm{~s})$ \\
\hline & $\mathrm{C}_{28} \mathrm{H}_{44}$ & $5 \beta(\mathrm{H})$ ergostane $(20 \mathrm{R})$ \\
\hline & $\mathrm{C}_{2 .} \mathrm{H}_{46}$ & 50(H) stigrnastane (20s) \\
\hline 19 & $\mathrm{C}_{29} \mathrm{H}_{46}$ & $5 \alpha(\mathrm{H})$ stigmastane $(20 \mathrm{~S})$ \\
\hline \multirow[t]{2}{*}{20} & $\mathrm{C}_{28} \mathrm{H}_{4}$ & Sa(h) ergostane $(20 \mathrm{R})$ \\
\hline & $\mathrm{C}_{29} \mathrm{H}_{46}$ & $5 \beta(\mathrm{H})$ stigmastane $(20 \mathrm{R})$ \\
\hline 21 & $\mathrm{C}_{20} \mathrm{H}_{46}$ & Sor(H) stigmastane $(20 \mathrm{R})$ \\
\hline
\end{tabular}

Table 6. The peaks identified for $\mathrm{m} / \mathrm{a}=253$ (monoaromatic steranes) mass chromatogram from stepwise HT-SFE of Posidonia shale at $50^{\circ} \mathrm{C}$ (The name of peaks: The biomarker Guide, Peters and Molddowan, 1993. pg.: 79)

\begin{tabular}{|c|c|c|}
\hline Peak number & Formula & Name \\
\hline 22 & $\mathrm{C}_{26} \mathrm{H}_{32}$ & Cholestane (20S) \\
\hline \multirow[t]{2}{*}{23} & $\mathrm{C}_{2} \mathrm{H}_{32}$ & Cholestane $(20 \mathrm{R})$ \\
\hline & $\mathrm{C}_{27} \mathrm{H}_{34}$ & Ergostane (20S) \\
\hline 24. & $\mathrm{O}_{2} \mathrm{H}_{16}$ & Stignuastane $(20$ s) \\
\hline 25 & $\mathrm{C}_{27} \mathrm{H}_{34}$ & Ergostane (20R) \\
\hline 26. & $\mathrm{C}_{28} \mathrm{H}_{36}$ & Stigmastane (20R) \\
\hline
\end{tabular}

Table 7. The peaks identified for $\mathrm{m} / \mathrm{z}=231$ (triaromatic steranes) mass chromatogram from stepwise HT-SFE of Posidonia shale at $50^{\circ} \mathrm{C}$ (The name of peaks: The biomarker Guide, Peters and Molddowan, 1993. pg.: 81) 


\begin{tabular}{|c|c|c|c|c|}
\hline Comp & $\begin{array}{c}50^{\circ} \mathrm{C} \\
(\mathrm{ppm})(\mathrm{S} . \mathrm{D} .)\end{array}$ & $\begin{array}{c}150^{\circ} \mathrm{C} \\
\text { (ppm)(S.D.) }\end{array}$ & $\begin{array}{c}250^{\circ} \mathrm{C} \\
\text { (ppm)(S.D.) }\end{array}$ & $\begin{array}{c}350^{\circ} \mathrm{C} \\
(\mathrm{ppm})(\text { S.D. })\end{array}$ \\
\hline $\mathrm{C}_{29} \alpha \beta$ & $0.522(0.01)$ & $0.827(0.4)$ & $0.183(0.07)$ & $0.110(0.03)$ \\
\hline$C_{29} \beta 0 \alpha$ & $0.126(0.008)$ & $0.17 \%(0.03)$ & $0.025(0.008)$ & $0.029(0.01)$ \\
\hline$C_{30} \alpha \beta$ & $0.967(0.06)$ & $1.34(0.6)$ & $0.118(0.05)$ & $0.031(0.01)$ \\
\hline C.6fo & $0214(0,01)$ & $0.280(0.07)$ & $0020(0008)$ & $0017(0008)$ \\
\hline$C_{31} \alpha \beta(S)$ & $0.377(0.03)$ & $0.444(0.09)$ & $0.054(0.02)$ & $0.009(0.004)$ \\
\hline C & $0.276(0.02)$ & $0.327(0.06)$ & $0.040(0.01)$ & $0018(0,008)$ \\
\hline $\mathrm{C}_{32} \alpha \beta(\mathrm{S})$ & $0.212(0.02)$ & $0.259(0.08)$ & $0.025(0.01)$ & $0.003(0.0007)$ \\
\hline$\left(c_{2} \times 0\right)(R)$ & $0202(002)$ & $0.249(0.09)$ & $0.028(0.01)$ & $00013(0.005)$ \\
\hline$C_{33} \alpha \beta(S)$ & $0.337(0.05)$ & $0.376(0.08)$ & $0.030(0.01)$ & N.D. \\
\hline $\mathrm{C}, \mathrm{s}$ (P(R) & $0.327(0.05)$ & $0.3470 .07)$ & $0.037(0.01)$ & ND \\
\hline $\mathrm{C}_{34} \alpha \beta(\mathrm{S})$ & $0.232(0.04)$ & $0.210(0.03)$ & $0.016(0.007)$ & N.D. \\
\hline$C_{3}, a b(R)$ & $0204(0,02)$ & $(0.198(0.03)$ & $0.022(0.008)$ & No \\
\hline$C_{35} \alpha \beta(S)$ & $0.170(0.04)$ & $0.162(0.03)$ & $0.014(0.007)$ & N.D. \\
\hline $8,30 \beta(\mathrm{R})$ & $0,238(0.05)$ & $0.203(0.03)$ & $0.017(0.007)$ & N D \\
\hline
\end{tabular}

Table 8. Recoveries of Hopanes (S.D.) from triplicate stepwise HT-SFE of Posidonia shale 


\begin{tabular}{|c|c|c|c|c|}
\hline Comp & $\begin{array}{c}50^{\circ} \mathrm{C} \\
(\text { ppm)(S.D.) }\end{array}$ & $\begin{array}{c}150^{\circ} \mathrm{C} \\
\text { (ppm)(S.D.) }\end{array}$ & $\begin{array}{c}250^{\circ} \mathrm{C} \\
\text { (ppm)(S.D.) }\end{array}$ & $\begin{array}{c}350^{\circ} \mathrm{C} \\
(\text { ppm)(S.D.) }\end{array}$ \\
\hline $5 \beta(H) C_{27}(20 S)$ & $0388(0.04)$ & $0.444(0.03)$ & $0.020(0.008)$ & N.D. \\
\hline $5 \beta(H) C_{2}(20 R)$ & $0.485(0.03)$ & $0.541(0.06)$ & $00270001)$ & N. D. \\
\hline * & $1.38(0.11)$ & $1.76(0.22)$ & $0.083(0.04)$ & N.D. \\
\hline$\%$ & $2.68(0.24)$ & $3,770,371$ & $01440,007)$ & ND. \\
\hline $5 \alpha(\mathrm{H}) \mathrm{C}_{29}(20 \mathrm{~S})$ & $0.818(0.06)$ & $1.13(0.01)$ & $0.046(0.02)$ & N.D. \\
\hline $17.6 * \%$ & $125(0.06)$ & $152(0.05)$ & $0056(003)$ & No. \\
\hline $5 \alpha(\mathrm{H}) \mathrm{C}_{29}(20 \mathrm{R})$ & $0.502(0.005)$ & $0.618(0.09)$ & $0.023(0.01)$ & N.D. \\
\hline
\end{tabular}

*: $5 \alpha(\mathrm{H}) \mathrm{C}_{2}(20 \mathrm{~S})+5 \beta(\mathrm{H}) \mathrm{C}_{28}(20 \mathrm{~S})$

**: $5 \alpha(\mathrm{H}) \mathrm{C}_{27}(20 \mathrm{R})+5 \alpha(\mathrm{H}) \mathrm{C}_{28}(20 \mathrm{~S})+5 \beta(\mathrm{H}) \mathrm{C}_{28}(20 \mathrm{R})+5 \beta(\mathrm{H}) \mathrm{C}_{28}(20 \mathrm{~S})$

$* * *: 5 \alpha(H) C_{28}(20 \mathrm{R})+5 \beta(H) C_{30}(20 R)$

Table 9. Recoveries of monoaromatic steranes (S.D.) from triplicate stepwise HT-SFE of Posidonia shale

\begin{tabular}{|c|c|c|c|c|}
\hline Comp & $\begin{array}{c}50^{\circ} \mathrm{C} \\
(\mathrm{ppm})(\mathrm{S} . \mathrm{D} .)\end{array}$ & $\begin{array}{c}150^{\circ} \mathrm{C} \\
\text { (ppm)(S.D.) }\end{array}$ & $\begin{array}{c}250^{\circ} \mathrm{C} \\
(\mathrm{ppm})(\text { S.D. })\end{array}$ & $\begin{array}{c}350^{\circ} \mathrm{C} \\
\text { (ppm)(S.D.) }\end{array}$ \\
\hline $\mathrm{C}_{26}(20 \mathrm{~S})$ & $1.05(0.09)$ & $1.07(0.11)$ & $0.088(0.007)$ & $0.005(0.003)$ \\
\hline \% & $2,37(0.36)$ & $2.18(0.31)$ & $0.149(003)$ & $0.010(0,005)$ \\
\hline $\mathrm{C}_{28}(20 \mathrm{~S})$ & $1.39(0.32)$ & $1.38(0.21)$ & $0.080(0.01)$ & $0.007(0.002)$ \\
\hline$(2,(20 x)$ & $1.32(0.43)$ & $1,16(0,16)$ & $0.078(0.01)$ & $0,005(00003)$ \\
\hline $\mathrm{C}_{28}(20 \mathrm{R})$ & $2.12(0.45)$ & $1.38(0.24)$ & $0.083(0.02)$ & $0.008(0.002)$ \\
\hline
\end{tabular}

$=\mathrm{C}_{26}(20 \mathrm{R})+\mathrm{C}_{27}(20 \mathrm{~S})$

Table 10. Recoveries of triaromatic steranes (S.D.) from triplicate stepwise HTSFE of Posidonia shale 


\begin{tabular}{|c|c|c|c|c|}
\hline Comp & $50^{\circ}(\mathrm{C})(\mathrm{ppm})$ & $150^{\circ}(\mathrm{C})(\mathrm{ppm})$ & $250^{\circ}(\mathrm{C})(\mathrm{ppm})$ & $350^{\circ}(\mathrm{C})(\mathrm{ppm})$ \\
\hline$C_{30} \alpha \beta$ & 0.065 & 0.065 & 0.046 & 0.132 \\
\hline$C_{30}, 3 \alpha$ & 0052 & 0008 & 00030 & 0.182 \\
\hline$C_{31} \alpha \beta(S)$ & 0.022 & 0.023 & 0.016 & 0.010 \\
\hline$(\mathrm{C}, \propto \beta(\mathrm{R})$ & 0.107 & 0.109 & 8076 & $0.13 \%$ \\
\hline $\mathrm{C}_{32} \alpha \beta(\mathrm{S})$ & 0.005 & 0.006 & 0.004 & 0.004 \\
\hline $\mathrm{r}_{2} \times \mathrm{\beta}(\mathrm{R})$ & 0032 & 0032 & 00023 & 00056 \\
\hline
\end{tabular}

Table 11. Recoveries of Hopanes from single stepwise HT-SFE of Kupferschiefer shale

\begin{tabular}{|c|c|c|c|c|}
\hline Comp & $50^{\circ}(\mathrm{C})(\mathrm{ppm})$ & $150^{\circ}(\mathrm{C})(\mathrm{ppm})$ & $250^{\circ}(\mathrm{C})(\mathrm{ppm})$ & $350^{\circ}(\mathrm{C})(\mathrm{ppm})$ \\
\hline $5 \beta(\mathrm{H}) \mathrm{C}_{27}(20 \mathrm{~S})$ & 0.115 & 0.085 & 0.023 & 0.005 \\
\hline $5 \mathrm{BOH} \mathrm{C}_{22}(20 \mathrm{R})$ & 0.138 & 0.102 & 0.032 & 0.012 \\
\hline$*$ & 0.390 & 0.314 & 0.101 & 0.027 \\
\hline tw & 104 & 0824 & 0236 & 0086 \\
\hline $5 \alpha(\mathrm{H}) \mathrm{C}_{29}(20 \mathrm{~S})$ & 0.419 & 0.362 & 0.106 & 0.042 \\
\hline $4 * *$ & 0.612 & $1,473$. & 0.123 & 0002 \\
\hline $5 \alpha(\mathrm{H}) \mathrm{C}_{29}(20 \mathrm{R})$ & 0.304 & 0.243 & 0.065 & 0.034 \\
\hline
\end{tabular}

*: $5 \alpha(\mathrm{H}) \mathrm{C}_{27}(2 \mathrm{OS})+5 \beta(\mathrm{H}) \mathrm{C}_{28}(20 \mathrm{~S})$

**: $5 \alpha(H) C_{27}(20 \mathrm{R})+5 \alpha(H) C_{28}(20 \mathrm{~S})+5 \beta(H) C_{29}(20 \mathrm{~S})+5 \alpha(\mathrm{H}) \mathrm{C}_{29}(20 \mathrm{R})$

***: $5 \alpha(\mathrm{H}) \mathrm{C}_{28}(20 \mathrm{R})+5 \beta(\mathrm{H}) \mathrm{C}_{28}(2 \mathrm{R})$

Table 12. Recoveries of monoaromatic steranes from single stepwise HT-SFE of Kupferschiefer shale

\begin{tabular}{|c|c|c|c|c|}
\hline Comp & $50^{\circ}(\mathrm{C})(\mathrm{ppm})$ & $150^{\circ}(\mathrm{C})(\mathrm{ppm})$ & $250^{\circ}(\mathrm{C})(\mathrm{ppm})$ & $350^{\circ}(\mathrm{C})(\mathrm{ppm})$ \\
\hline $\mathrm{C}_{26}(20 \mathrm{~S})$ & 0.025 & 0.026 & 0.022 & 0.064 \\
\hline 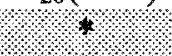 & 0.055 & 0.057 & 0,045 & 0.110 \\
\hline $\mathrm{C}_{28}(20 \mathrm{~S})$ & 0.077 & 0.085 & 0.062 & 0.147 \\
\hline $102(20 \mathrm{R})$ & 0.028 & 0.031 & 0026 & 0.071 \\
\hline $\mathrm{C}_{28}(20 \mathrm{R})$ & 0.068 & 0.066 & 0.055 & 0.152 \\
\hline
\end{tabular}

* $\mathrm{C}_{26}(20 \mathrm{R})+\mathrm{C}_{27}(20 \mathrm{~S})$

Table 13. Recoveries of triaromatic steranes from single stepwise HT-SFE of Kupferschiefer shale 
biomarkers. The majority of the hopanes in Posidonia shale were released at $50^{\circ} \mathrm{C}$ and $150^{\circ} \mathrm{C}$ (see Table 8). They likely belong to 'free' and/or 'weakly binding' categories, which are not strongly associated with $O M$ in sediments and, are, therefore, the easiest to be released. Small amount of hopanes extracted at $250^{\circ} \mathrm{C}$ were probably "strongly associated' species, which need higher thermal energy for their release. About $3 \%$ of hopanes were released at $350^{\circ} \mathrm{C}$ with a significantly different molecular distribution. The comparison of ion 191 mass chromatogram of hopanes from stepwise HT-SFE of Posidonia shale at $50^{\circ} \mathrm{C}$ and $350^{\circ} \mathrm{C}$ is shown in Figure 17. It is apparent that hopanes with immature configurations are released at $350^{\circ} \mathrm{C}$, suggesting a different speciation of these compounds from 'free' and 'strongly associated' species. Such changes of maturity parameter vs. temperature can provide insight to this different speciation. Tables 14 and 15 are summarized results of maturity parameter for hopanes at each temperature fraction from triplicate stepwise HT-SFE of Posidonia shale (the ratio of peak area were used for all maturity parameter calculation). A decrease of ratio $[22 S /(22 S+22 R)]$ and increase of ratio $\left[\beta \alpha\right.$-Moretanes $/ \alpha \beta$-hopanes] at extraction temperature of $350^{\circ} \mathrm{C}$, indicated that significant amount of immature configurations does exist in the 'trapped' or 'strongly associated' fraction. Such a maturity inversion (see Figures 18 and 19) agrees with the results observed by Jaffé and coworkers (1990) in ancient rock samples and, who suggested this to be caused by steric hindrance of isomerization of immature compounds 'trapped' within internal voids of macromolecular OM. Release of those 'trapped' compounds occurs during rearrangement of the macromolecular matrix under high temperature conditions. Interestingly, about $40 \%$ of hopanes in Kupferschiefer shale 

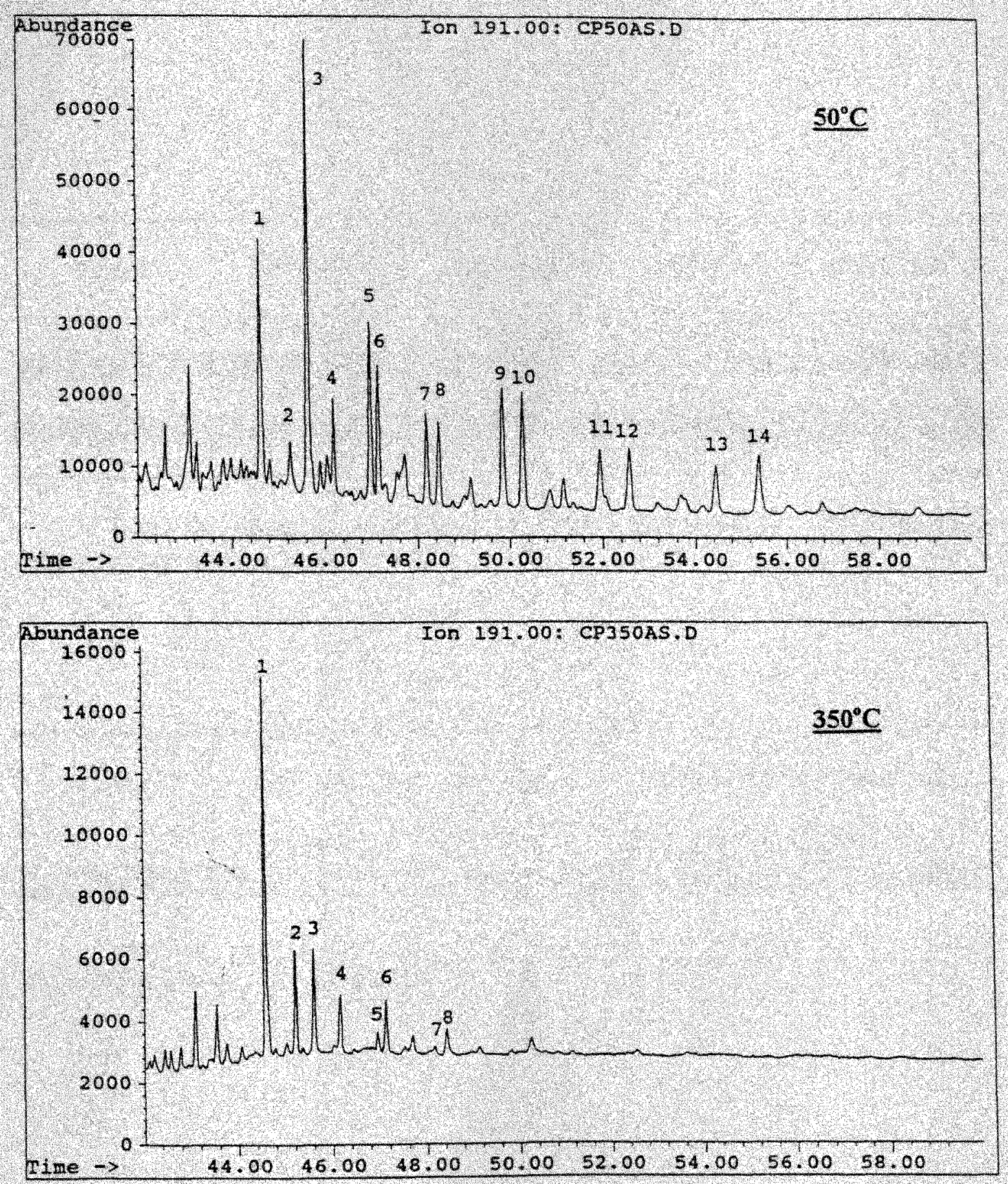

Figure 17. Mass chromatograms of hopanes $(\mathrm{m} / \mathrm{z}=191)$ from stepwise HT-SFE of Posidonia shale at $50^{\circ} \mathrm{C}$ and $350^{\circ} \mathrm{C}$ 


\begin{tabular}{|c|c|c|c|c|}
\hline Comp & $50^{\circ} \mathrm{C}$ (S.D.) & $150^{\circ} \mathrm{C}$ (S.D.) & $250^{\circ} \mathrm{C}$ (S.D.) & $350^{\circ} \mathrm{C}$ (S.D.) \\
\hline $\mathrm{C}_{31}$ & $0.578(0.002)$ & $0.576(0.005)$ & $0.576(0.002)$ & $0.325(0.01)$ \\
\hline $\mathrm{C}_{3} \mathrm{2}$ & $0.512(0.01)$ & $0.513(0.01)$ & $(0,475(0.004)$ & $0.217(0.03)$ \\
\hline $\mathrm{C}_{33}$ & $0.507(0.009)$ & $0.519(0.002)$ & $0.448(0.01)$ & N.D. \\
\hline $\mathrm{C}_{3 .}$ & $0.531(0.02)$ & $0514(0001)$ & $0.429(0.01)$ & N.D. \\
\hline $\mathrm{C}_{35}$ & $0.416(0.003)$ & $0.444(0.001)$ & $0.446(0.02)$ & N.D. \\
\hline
\end{tabular}

Table 14. Maturity parameter of $[22 S /(22 S+22 R)]$ (S.D.) for Posidonia shale from triplicate stepwise HT-SFE

\begin{tabular}{c|c|c|c|c}
\hline Comp & $50^{\circ} \mathbf{C}($ S.D. $)$ & $150^{\circ} \mathrm{C}($ S.D. $)$ & $250^{\circ} \mathrm{C}($ S.D. $)$ & $350^{\circ} \mathrm{C}($ S.D. $)$ \\
\hline $\mathrm{C}_{29}$ & $0.241(0.02)$ & $0.203(0.01)$ & $0.140(0.01)$ & $0.260(0.02)$ \\
\hline $\mathrm{C}_{30}$ & $0.221(0.003)$ & $0.199(0.02)$ & $0.168(0.003)$ & $0.356(0.06)$ \\
\hline
\end{tabular}

Table 15. Maturity parameter of [ $\beta \alpha-$ Moretane/ $\alpha \beta-H o p a n e]$ (S.D.)for Posidonia shale from triplicate stepwise HT-SFE 


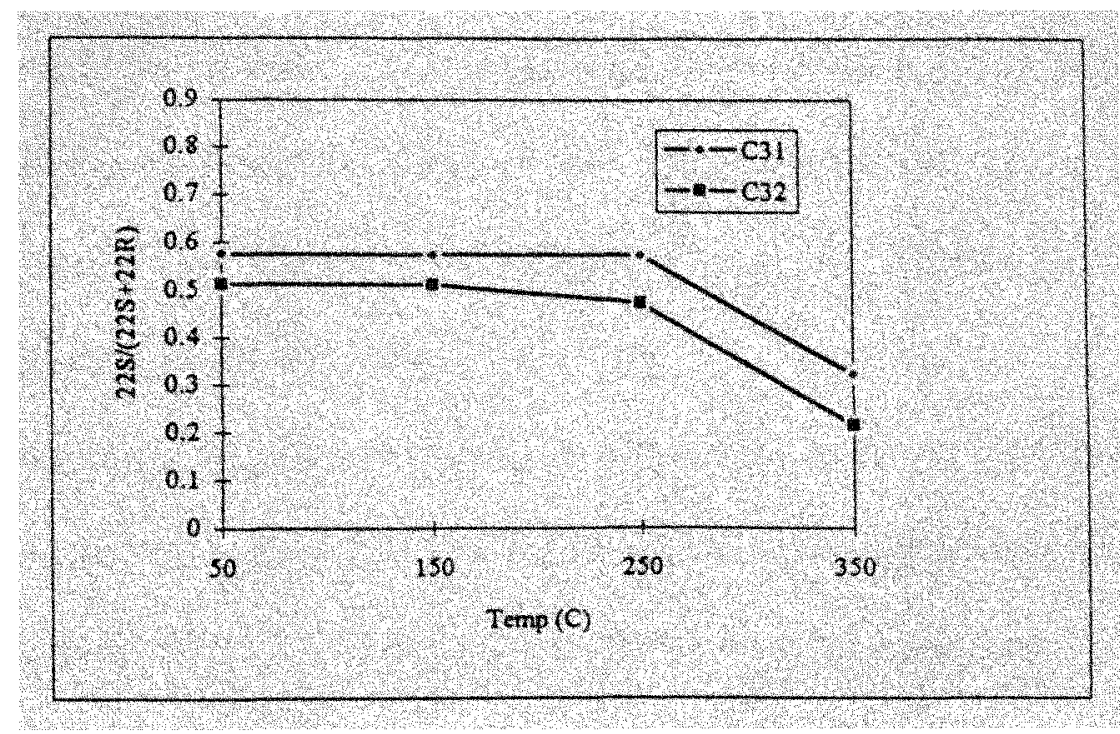

Figure 18. Maturity parameter of [22S/(22S+22R)] vs. temperature of Posidonia shale

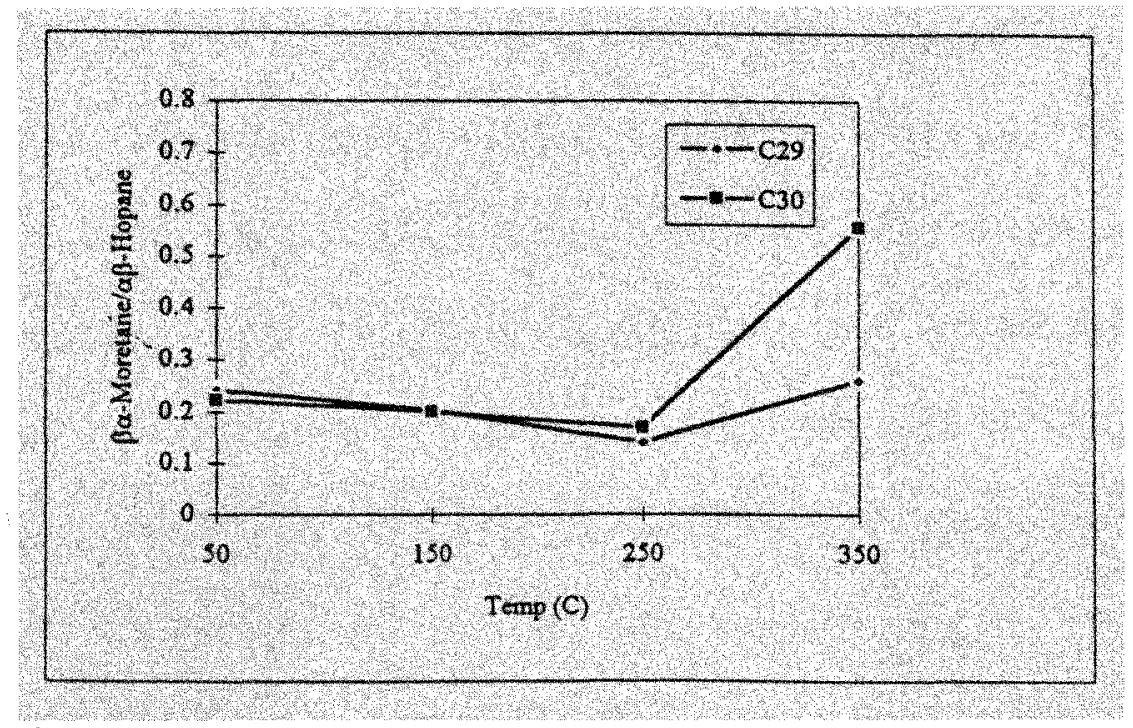

Figure 19. Maturity parameter of [ $\beta \alpha-$ Moretane/ $\alpha \beta-$ Hopane $]$ vs. temperature of Posidonia shale 
were released at $350^{\circ} \mathrm{C}$, much more than those in Posidonia shale (see Table 11). Correspondingly, the inversions of molecular maturity parameters of $[22 S /(22 S+22 R)]$ and [ $\beta \alpha-$ Moretane/ $\alpha \beta$-Hopane] for Kupferschiefer shale were more significant than for Posidonia shale. (See Tables 16, 17 and Figures 20 and 21). Apparently more hopanes are 'trapped' in Kupferschiefer shale.

Similar to the hopanes, for Posidonia shale, most mono and triaromatic steranes were released at $50^{\circ} \mathrm{C}$ and $150^{\circ} \mathrm{C}$. Very small amount of mono and triaromatic steranes were extracted at $250^{\circ} \mathrm{C}$. For extracts at $350^{\circ} \mathrm{C}$, only trace amounts of triaromatic steranes were found. Monoaromatic steranes were not detected at $350^{\circ} \mathrm{C}$ (Table 9 and 10). Table 18 illustrated the maturity parameter of $[\mathrm{TA} /(\mathrm{TA}+\mathrm{MA})]$ at each temperature fraction from triplicate stepwise HT-SFE of Posidonia shale. Interestingly, the ratio of $[\mathrm{TA} /(\mathrm{TA}+\mathrm{MA})]$ follows an increasing thermal maturity trend (opposed to the hopanes), which is that the ratio increases with increase of temperature (Table 18 and Figure 22). There are two possible reasons. One is possibly that the steric hindrance has no effect on aromatization process due to the planar molecular shape of the aromatic hydrocarbons. Therefore, 'trapped' monoaromatic steranes can still be converted to triaromatic steranes by temperature effects. The other is likely that triaromatic steranes have stronger interaction with the matrix than monoaromatic steranes (as shown by the behavior of the phenanthrenes, see below). The later are less aromatic, and less planar and should, therefore, have a weaker interaction with the organic matrix and can, therefore, be extracted at lower temperatures (i.e. lower energies). Tables 12 and 13 show the amount of mono and triaromatic steranes recovered from Kupferschiefer shale by stepwise 


\begin{tabular}{|c|c|c|c|c|}
\hline Comp & $50^{\circ} \mathrm{C}$ & $150^{\circ} \mathrm{C}$ & $250^{\circ} \mathrm{C}$ & $350^{\circ} \mathrm{C}$ \\
\hline $\mathrm{C}_{31}$ & 0.174 & 0.177 & 0.179 & 0.064 \\
\hline $\mathrm{C}_{32}$ & 0.148 & 0.148 & 0.153 & 00007 \\
\hline
\end{tabular}

Table 16. Maturity parameter of $[22 \mathrm{~S} /(22 \mathrm{~S}+22 \mathrm{R})]$ for Kupferschiefer shale from single stepwise HT-SFE

\begin{tabular}{c|c|c|c|c}
\hline Comp & $50^{\circ} \mathrm{C}$ & $150^{\circ} \mathrm{C}$ & $250^{\circ} \mathrm{C}$ & $\mathbf{3 5 0 ^ { \circ } \mathrm { C }}$ \\
\hline $\mathrm{C}_{30}$ & 0.802 & 0.734 & 0.669 & 1.379 \\
\hline
\end{tabular}

Table 17. Maturity parameter of [ $\beta \alpha-$ Moretane/ $\alpha \beta-$ Hopane] for Kupferschiefer shale from single stepwise HT-SFE

\begin{tabular}{c|c|c|c}
\hline $50^{\circ} \mathrm{C}($ S.D. $)$ & $150^{\circ} \mathrm{C}($ S.D. $)$ & $250^{\circ} \mathrm{C}$ (S.D.) & $350^{\circ} \mathrm{C}$ (S.D.) \\
\hline $0.516(8.2)$ & $0.414(8.5)$ & $0.548(14.4)$ & 1 \\
\hline
\end{tabular}

Table 18. Maturity parameter of $[\mathrm{TA} /(\mathrm{TA}+\mathrm{MA})]$ for Posidonia shale from triplicate stepwise HT-SFE

\begin{tabular}{c|c|c|c}
\hline $\mathbf{5 0} 0^{\circ} \mathrm{C}($ S.D. $)$ & $\mathbf{1 5 0 ^ { \circ } \mathrm { C } ( \text { S.D. } )}$ & $\mathbf{2 5 0 ^ { \circ } \mathrm { C } ( \text { S.D. } )}$ & $\mathbf{3 5 0}^{\circ} \mathrm{C}($ S.D. $)$ \\
\hline 0.077 & 0.099 & 0.235 & 0.679 \\
\hline
\end{tabular}

Table 19. Maturity parameter of $[\mathrm{TA} /(\mathrm{TA}+\mathrm{MA})]$ for Kupferschierfer shale from single stepwise HT-SFE 


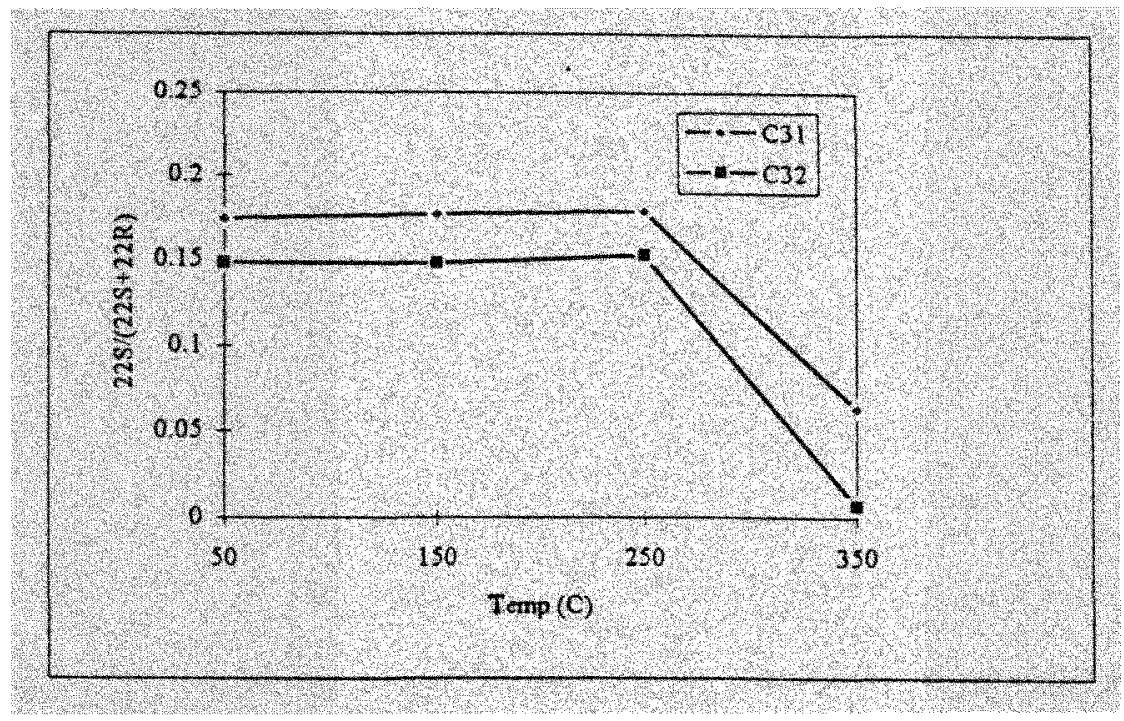

Figure 20. Maturity parameter of $[22 \mathrm{~S} /(22 \mathrm{~S}+22 \mathrm{R})]$ vs. temperature of Kupferschiefer shale

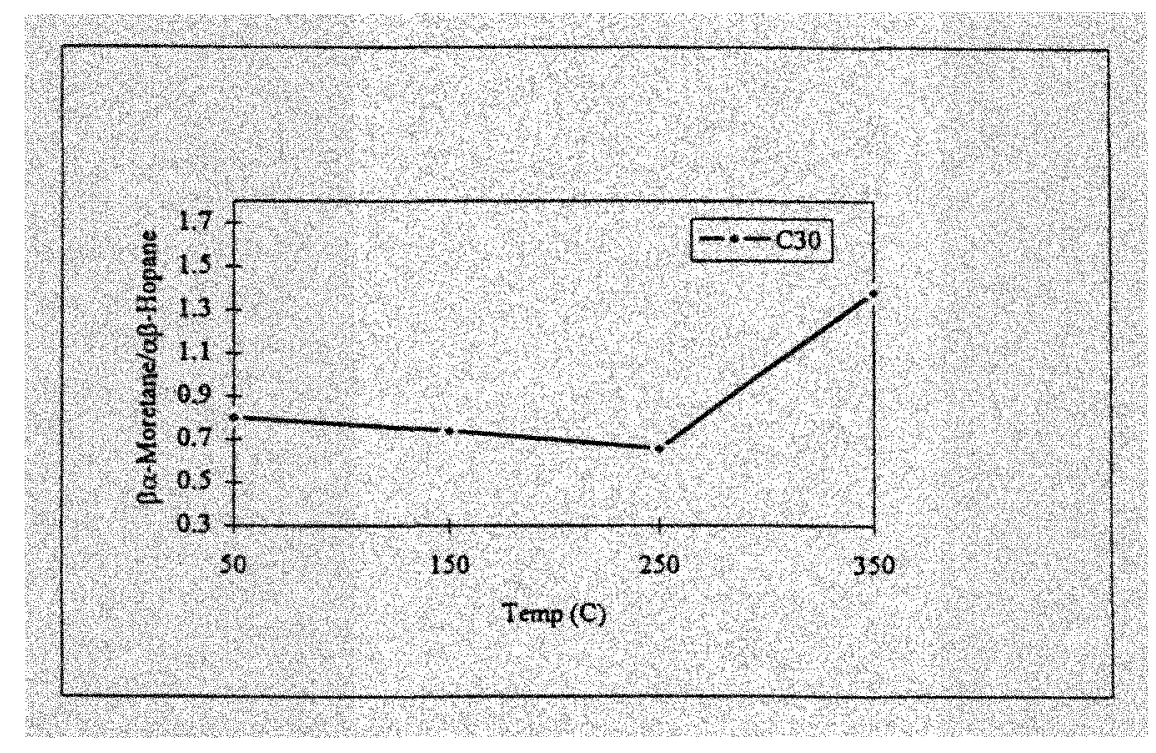

Figure 21. Maturity parameter of [ $\beta \alpha-$ Moretane/ $\alpha \beta-$ Hopane $]$ vs. temperature of Kupferschiefer shale 


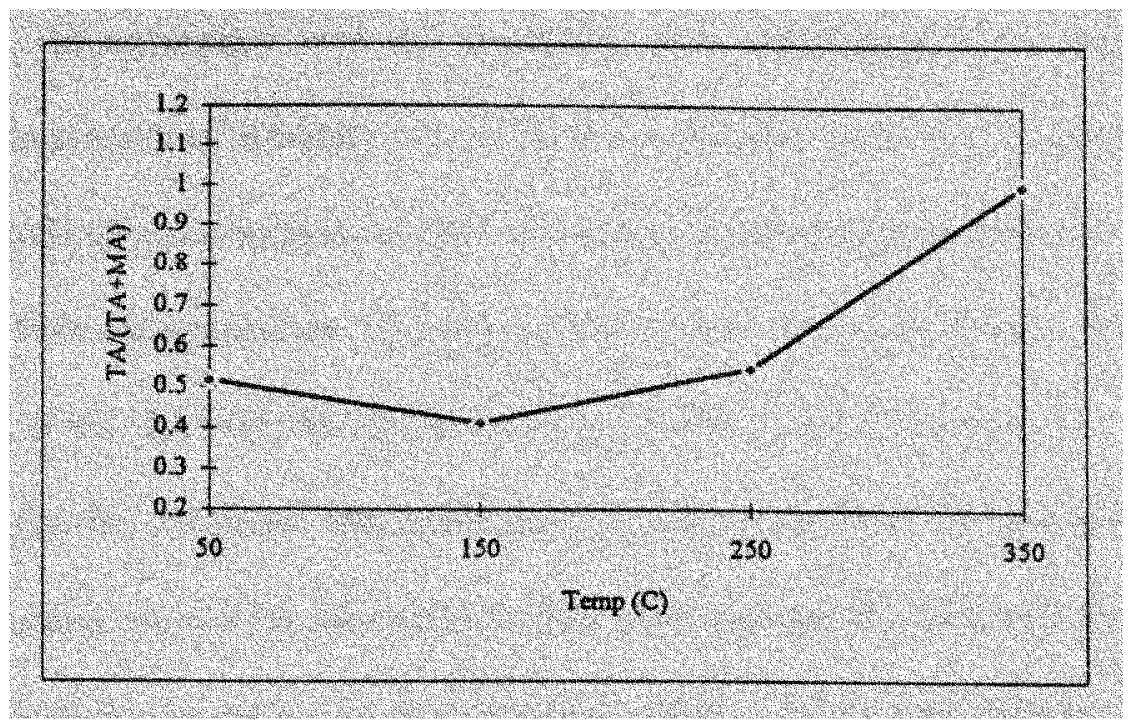

Figure 22. Maturity parameter of $[\mathrm{TA} /(\mathrm{MA}+\mathrm{TA})]$ vs. temperature of Posidonia shale

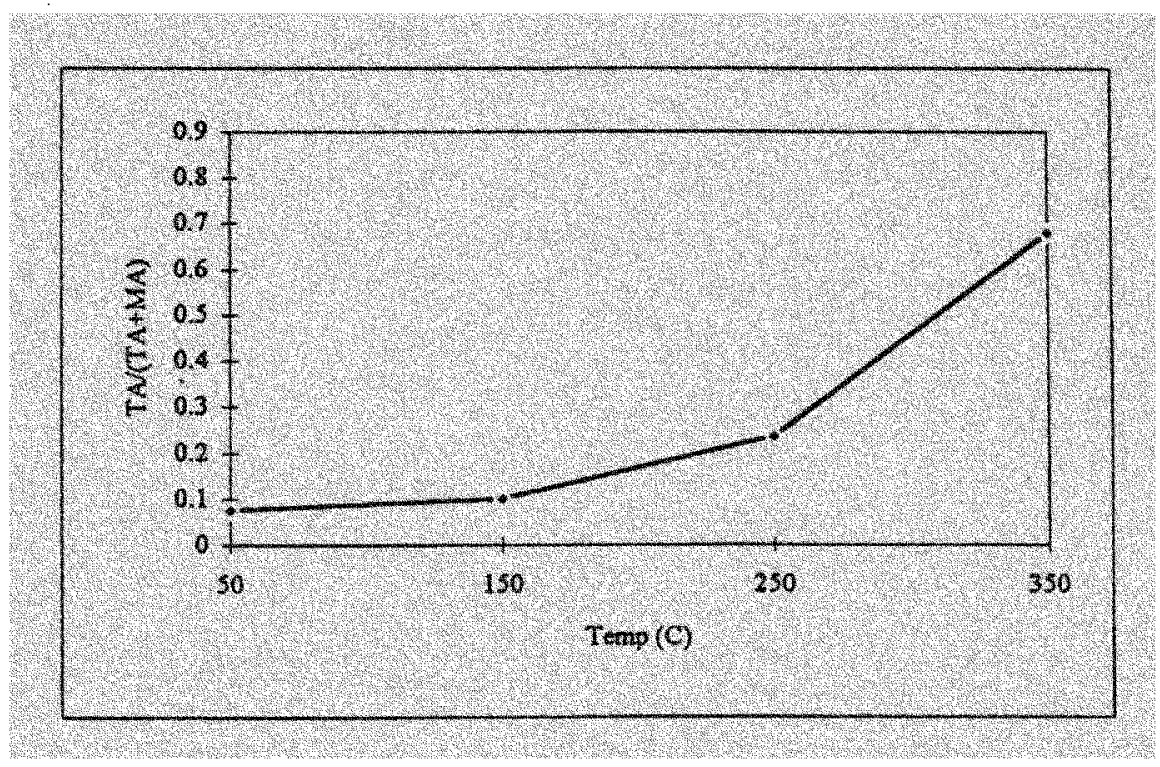

Figure 23. Maturity parameter of $[\mathrm{TA} /(\mathrm{MA}+\mathrm{TA})]$ vs. temperature of Kupferschiefer shale 
HT-SFE. In agreement with the Posidonia shale experiment, it is apparent that a tremendous amount of aromatic steranes in Kupferschiefer shale was 'trapped' with in the internal voids of macromolecular OM. However, the aromatic steranes are not sterically hindered from aromatization reactions when in the 'trapped' form. Therefore, the increment in the $[\mathrm{TA} /(\mathrm{TA}+\mathrm{MA})]$ was observed (Table 19 and Figure 23).

It can be concluded that molecular maturity parameters of biomarkers can be a useful geochemical tool for speciation studies with stepwise HT-SFE as a technique. The thermal maturity inversion of the hopanes clearly shows the release of 'trapped' hydrocarbons at elevated SFE extraction temperature. 
9.2. Stepwise HT-SFE, thermodesorption and Soxhlet extraction on recovery of hydrocarbons and biomarkers

Aliphatic and aromatic hydrocarbons detected in ancient sediments are believed to be derived from the thermal degradation of kerogen. As described in section 6.1., Kerogen, which is the product of diagenesis, undergoes thermal decomposition (massive bond cleavage) due to temperature effects during catagenesis.

Aliphatic hydrocarbons, such as n-alkanes, as well as branched alkanes (pristane and phytane), and aromatic hydrocarbons, such as naphthalene, alkyl-naphthalenes, anthracene, alkyl-anthracenes, phenanthrene, alkyl-phenanthrenes in Posidonia shale and biomarkers, such as hopanes, monoaromatic steranes and triaromatic steranes in both Posidonia and Kupferschiefer shales were target analytes. The ion 57 mass chromatogram of aliphatic hydrocarbons and the ions $128,142,156$ and 170 of naphthalene, methylnaphthalenes, dimethyl-naphthalenes and trimethyl-naphthalenes, as well as the ions 178 , 192 and 206 mass chromatograms of phenanthrene, methyl-phenanthrenes and dimethylphenanthrenes (as well as the corresponding anthracenes) from stepwise HT-SFE of Posidonia shale at $50^{\circ} \mathrm{C}$ fraction (and $350^{\circ} \mathrm{C}$ fraction for phenanthrenes only) are shown in Figures 24, 25, 26 and 27. The peaks identified are listed in Tables 20,21 and 22. The mass chromatograms and the peaks identified of biomarkers are shown in section 9.1 .

Average results of the recovery of aliphatic and aromatic hydrocarbons from each fraction of triplicate stepwise HT-SFE of Posidonia shale are summarized in Tables 23, 24 and 25. Average results of the recovery of biomarkers are shown in section 9.1.. For aliphatic and aromatic hydrocarbons, it is apparent that recovery from stepwise HT-SFE is 


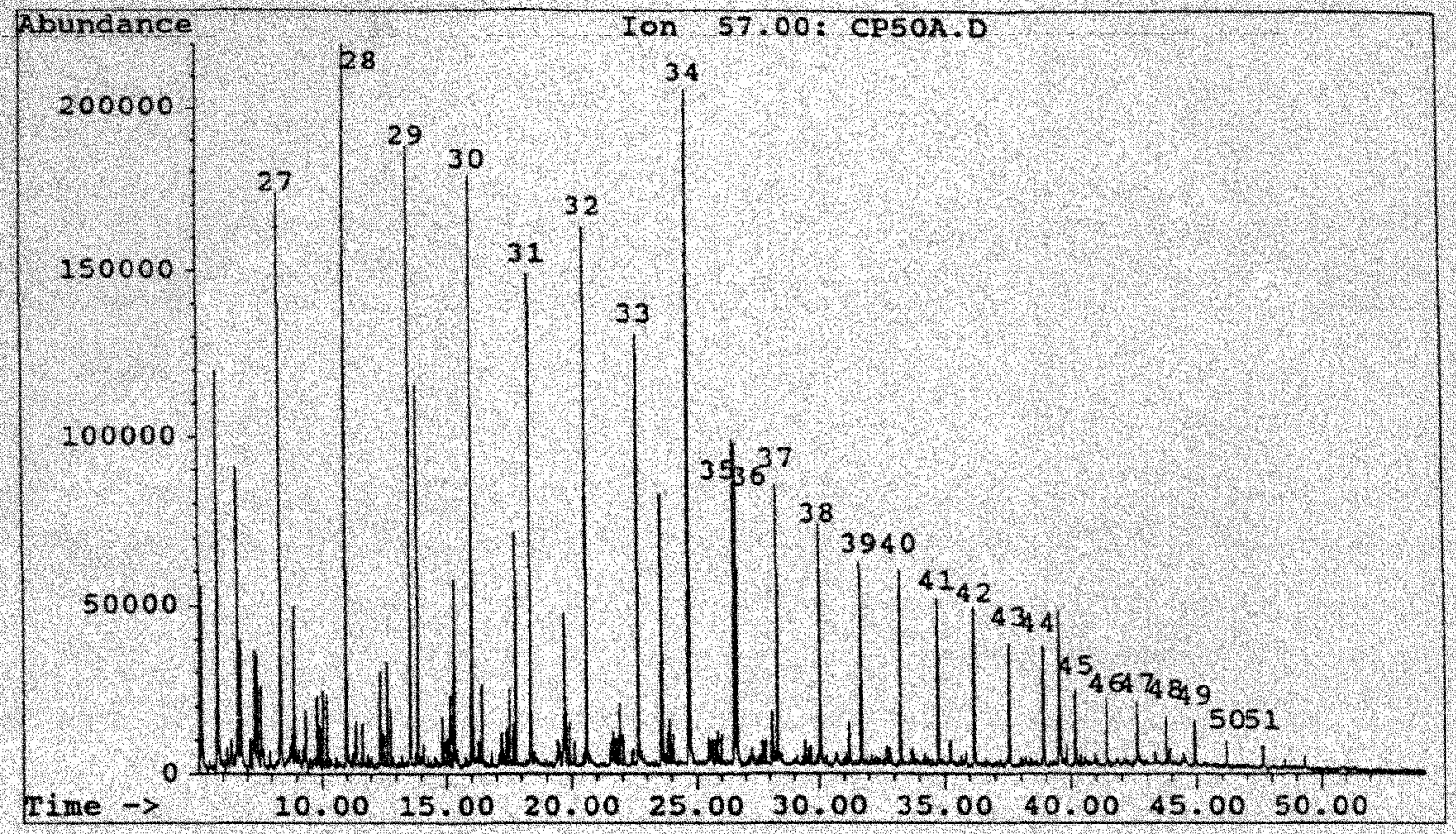

Figure 24. $m / z=57$ Mass chromatogram of aliphatic hydrocarbons from stepwise HT-SFE of Posidonia shale at $50^{\circ} \mathrm{C}$

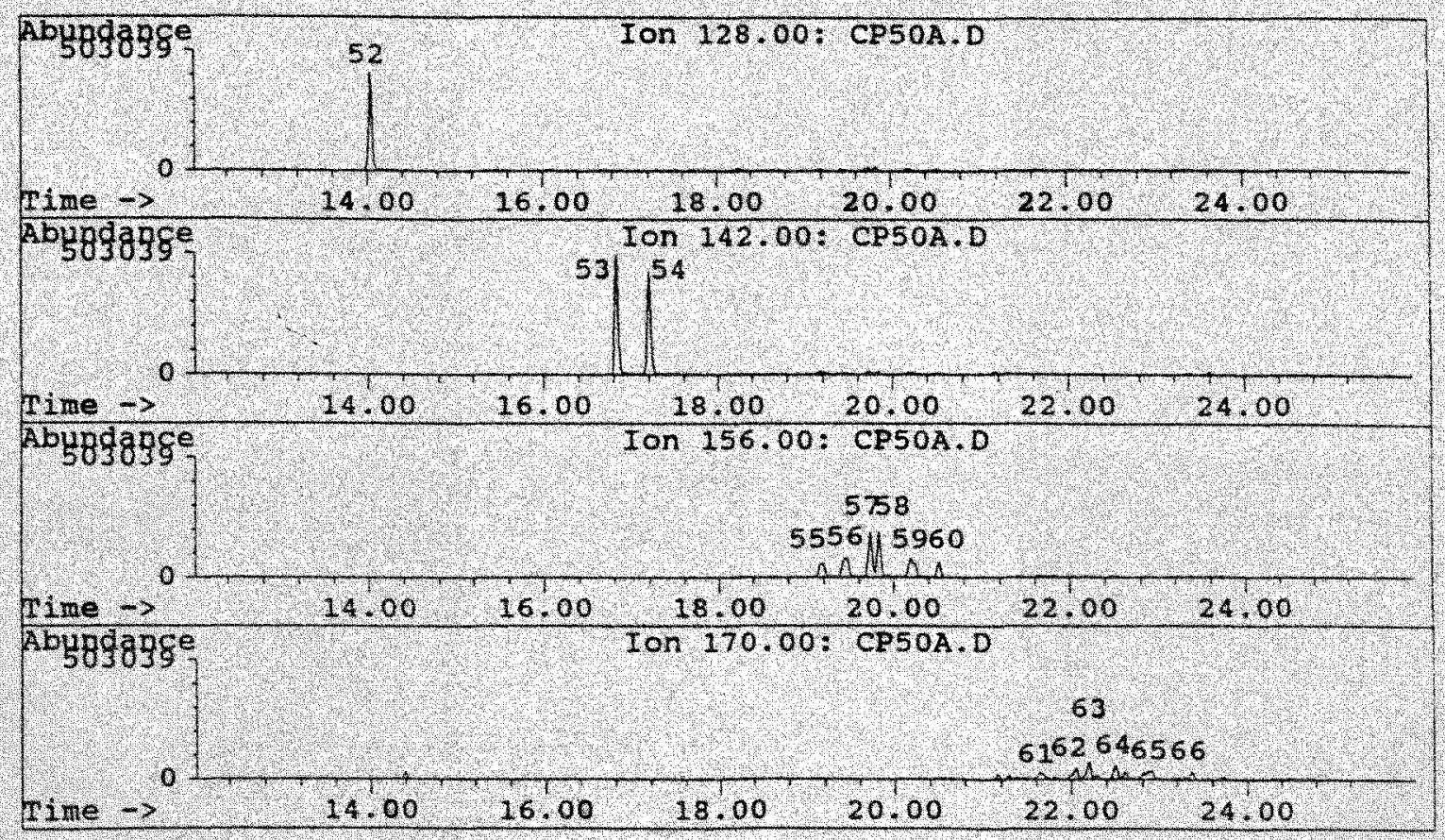

Figure 25. $m / z=128,142,156$ and 170 Mass chromatograms of naphthalene, methyl-naphthalenes, dimethyl-naphthalenes and trimethyl-naphthalenes (aromatic hydrocarbons) from stepwise HT-SFE of Posidonia shale at $50^{\circ} \mathrm{C}$ 


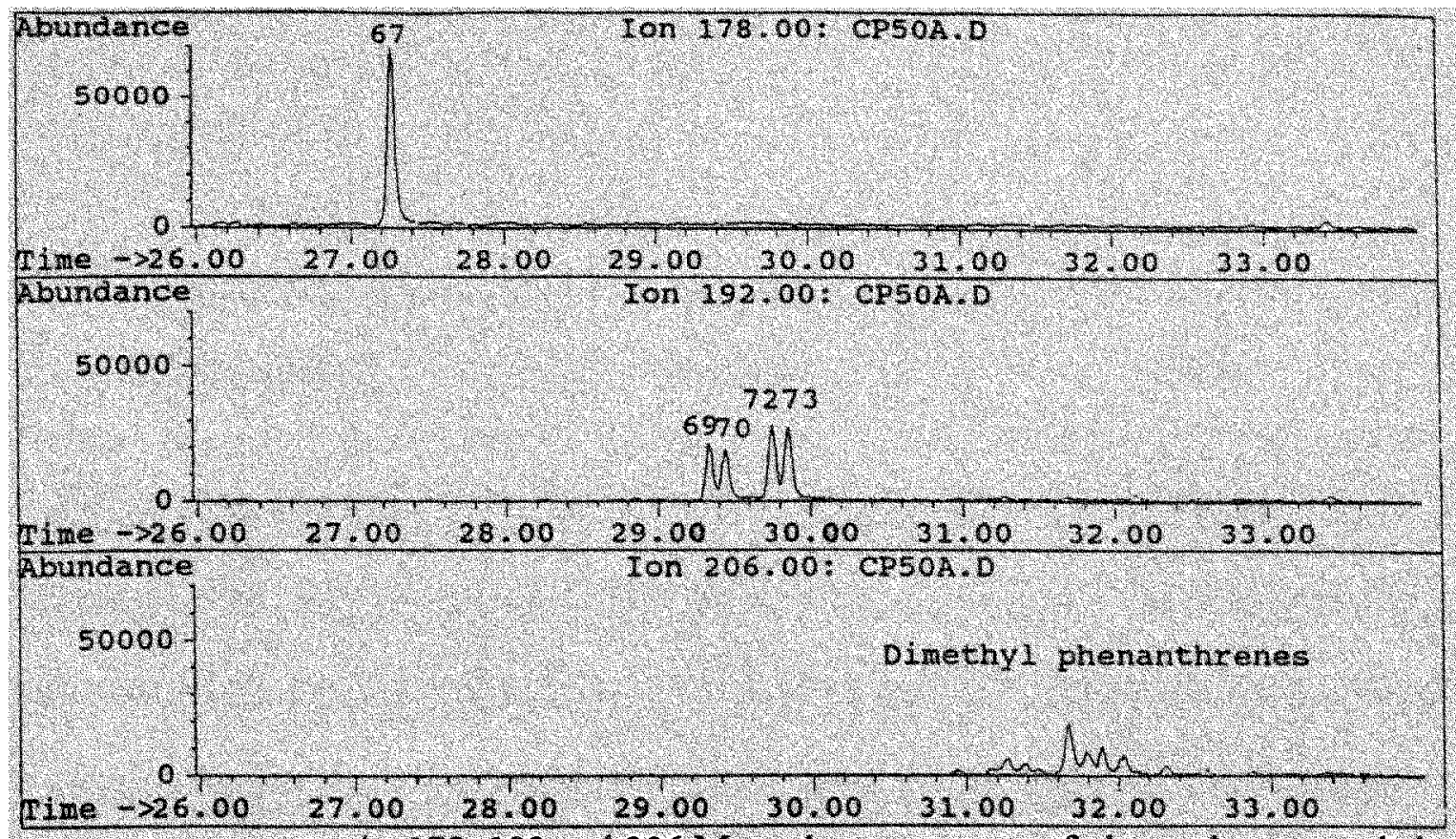

Figure 26. $\mathrm{m} / \mathrm{z}=178,192$ and 206 Mass chromatograms of phenanthrene, methylphenantnrenes and dimethyl-phenanthrenes (aromatic hydrocarbons) from stepwise HTSFE of Posidonia shale at $50^{\circ} \mathrm{C}$

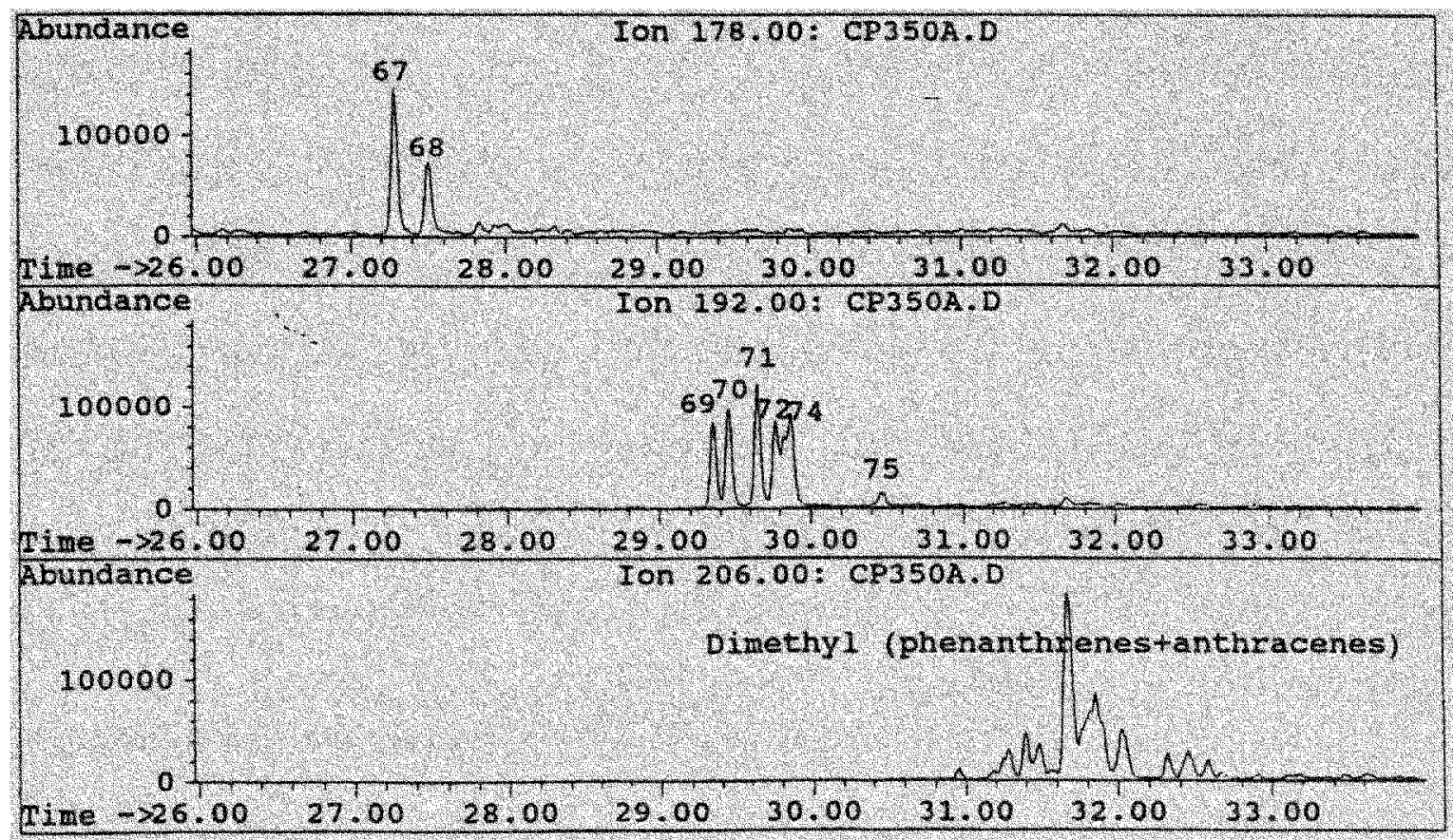

Figure 27. $\mathrm{m} / \mathrm{z}=178,192$ and 206 Mass chromatograms of phenanthrene, anthracene, methyl-phenanthrenes, methyl-anthracens, dimethyl-phenanthrenes and dimethyl-anthracenes (aromatic hydrocarbons) from stepwise HT-SFE of Posidonia shale at $350^{\circ} \mathrm{C}$ 


\begin{tabular}{|c|c|c|}
\hline Peak number & Formula & Name \\
\hline 27 & $\mathrm{C}_{10} \mathrm{H}_{22}$ & Decane \\
\hline 28 & $\mathrm{C}_{1:} \mathrm{H}_{24}$ & Undecane \\
\hline 29 & $\mathrm{C}_{12} \mathrm{H}_{26}$ & Dodecane \\
\hline 30 & $\mathrm{C}_{3} \mathrm{H}_{28}$ & Thecane. \\
\hline 31 & $\mathrm{C}_{14} \mathrm{H}_{30}$ & Tetradecane \\
\hline 32 & $\mathrm{C}_{1} \mathrm{SH}_{32}$ & Peratadecane \\
\hline 33 & $\mathrm{C}_{16} \mathrm{H}_{34}$ & Hexadecane \\
\hline 34 & $\mathrm{C}_{7} \mathrm{H}_{26}+\mathrm{C}_{1} \mathrm{H}_{6}(\mathrm{Pr})$ & Heptadecane+Pristane \\
\hline 35 & $\mathrm{C}_{18} \mathrm{H}_{38}$ & Octadecane \\
\hline 36 & $\mathrm{C}_{22} \mathrm{H}_{42}\left(\mathrm{P} \mathrm{H}_{\mathrm{y}}\right)$ & Phytare \\
\hline 37 & $\mathrm{C}_{19} \mathrm{H}_{40}$ & Nonadecane \\
\hline 38 & $\mathrm{C}_{20} \mathrm{H}_{42}$ & Eicosane \\
\hline 39 & $\mathrm{C}_{21} \mathrm{H}_{44}$ & Heneicosane \\
\hline 40. & $\mathrm{C}_{22} \mathrm{H}_{46}$ & Docosane. \\
\hline 41 & $\mathrm{C}_{23} \mathrm{H}_{48}$ & Tricosane \\
\hline 42. & $\mathrm{C}_{24} \mathrm{H}_{\mathrm{H}}$ & Tetracosane: \\
\hline 43 & $\mathrm{C}_{25} \mathrm{H}_{52}$ & Pentacosane \\
\hline 46 & $\mathrm{C}_{2,} \mathrm{H}_{3,}$ & Hexacosane \\
\hline 45 & $\mathrm{C}_{27} \mathrm{H}_{56}$ & Heptacosane \\
\hline 46 & $\mathrm{C}_{28} \mathrm{H}_{58}$ & Octacosarte \\
\hline 47 & $\mathrm{C}_{29} \mathrm{H}_{60}$ & Nonacosane \\
\hline 48 & $\mathrm{C}_{30} \mathrm{H}_{62}$ & Tracontane: \\
\hline 49 & $\mathrm{C}_{31} \mathrm{H}_{64}$ & Hentriacontane \\
\hline 50. & $\mathrm{C}_{3, H_{6}}$ & Dotriacontane \\
\hline 51 & $\mathrm{C}_{33} \mathrm{H}_{68}$ & Tritriacontane \\
\hline
\end{tabular}

Table 20. The peaks identified for $\mathrm{m} / \mathrm{z}=57$ (aliphatic hydrocarbons) mass chromatogram from stepwise HT-SFE of Posidonia shale at $50^{\circ} \mathrm{C}$ 


\begin{tabular}{|c|c|c|}
\hline Peak number & Formula & Name \\
\hline 52 & $\mathrm{C}_{10} \mathrm{H}_{8}$ & Naphthalene \\
\hline 3. & $C_{11} H_{10}$ & C.1 nethyl-naphthalene. \\
\hline 54 & $\mathrm{C}_{11} \mathrm{H}_{10}$ & C-2 methyl-naphthalene \\
\hline S & $\mathrm{C}_{1} \mathrm{H}_{\mathrm{2}} \mathrm{Z}$ & -ethylt 2 -ethyl-nophthalene. \\
\hline 56 & $\mathrm{C}_{12} \mathrm{H}_{12}$ & $2,6+2,7$ dimethyl-naphthalene \\
\hline S7. & $\mathrm{C}_{2} \mathrm{H}_{12}$ & $1,3+1,7$ dimetrul naphthalene. \\
\hline 58 & $\mathrm{C}_{12} \mathrm{H}_{12}$ & 1,6 dimethyl- naphthalene \\
\hline 59. & $\mathrm{C}_{1,1} \mathrm{H}_{42}$ & $=1,4+1,3+1,5$ dinetlyl - naphthatere \\
\hline 60 & $\mathrm{C}_{12} \mathrm{H}_{12}$ & 1,8 dimethyl- naphthalene \\
\hline 61 & $\mathrm{C}_{3} \mathrm{H}_{1}$. & (1, 7 trmethyl naphlthalene. \\
\hline 62 & $\mathrm{C}_{13} \mathrm{H}_{14}$ & $1,3,6$ trimethyl-naphthalene \\
\hline 6.3 & $\mathrm{C}_{3} \mathrm{H}_{1}$ & $.9 ., 6.1,3,5$ trinethy -naphthalene. \\
\hline 64 & $\mathrm{C}_{13} \mathrm{H}_{14}$ & 2,3,6 trimethyl-naphthalene \\
\hline 65 & $\mathrm{C}_{1 . \mathrm{I}_{14}}$ & $1,2,7+1,6,7+1,2,6$ trinethyl-naphthalene \\
\hline 66 & $\mathrm{C}_{13} \mathrm{H}_{14}$ & $1,2,5$ trimethyl-naphthalene \\
\hline
\end{tabular}

Table 21. The peaks identified for $\mathrm{m} / \mathrm{z}=128,142,156$ and 170 (aromatic hydrocatbons) mass chromatogram from stepwise HT-SFE of Posidonia shale at $50^{\circ} \mathrm{C}$

\begin{tabular}{|c|c|c|}
\hline Peak number & Formula & Name \\
\hline 67 & $\mathrm{C}_{14} \mathrm{H}_{10}$ & Phenanthrene \\
\hline 68. & $\mathrm{C}_{1} \mathrm{H}_{1}$ & Antluracene \\
\hline 69 & $\mathrm{C}_{15} \mathrm{H}_{12}$ & 3 methyl-phenanthrene \\
\hline 70 & $\mathrm{C}_{1.1} \mathrm{H}_{1}$ & 2 methyl plenanthrene. \\
\hline 71 & $\mathrm{C}_{15} \mathrm{H}_{12}$ & 2 methyl-anthracene \\
\hline 1.2. & $C_{1} \mathrm{H}_{12}$. & 9 methyl phenanthrene. \\
\hline 73 & $\mathrm{C}_{15} \mathrm{H}_{12}$ & 1 methyl-phenanthrene \\
\hline 14 & $\mathrm{C}_{1} \mathrm{H}_{12}$ & 1 nethy phenanthrene 1 neflyllanthracere \\
\hline 75 & $\mathrm{C}_{15} \mathrm{H}_{12}$ & 9 methyl-anthracene \\
\hline
\end{tabular}

Table 22. The peaks identified for $\mathrm{m} / \mathrm{z}=178,192$, and 206 (aromatic hydrocarbons) mass chromatogram from stepwise HT-SFE of Posidonia shale at $50^{\circ} \mathrm{C}$ and $350^{\circ} \mathrm{C}$ 


\begin{tabular}{|c|c|c|c|c|}
\hline Comp & $\begin{array}{c}50^{\circ} \mathrm{C} \\
(\mathrm{ppm})(\mathrm{S} . \mathrm{D} .)\end{array}$ & $\begin{array}{c}150^{\circ} \mathrm{C} \\
(\mathrm{ppm})(\text { S.D. })\end{array}$ & $\begin{array}{c}250^{\circ} \mathrm{C} \\
(\mathrm{ppm})(\mathrm{S} . \mathrm{D} .)\end{array}$ & $\begin{array}{c}350^{\circ} \mathrm{C} \\
(\mathrm{ppm})(\mathrm{S} . \mathrm{D} .)\end{array}$ \\
\hline $\mathrm{C}_{10}$ & $14.1(0.9)$ & $1.71(0.3)$ & $0.515(0.1)$ & $0.788(0.2)$ \\
\hline $\mathrm{C}_{1:}$ & $150(12)$ & $1.78(0.3)$ & $0.536(0.1)$ & $115(03)$. \\
\hline $\mathrm{C}_{12}$ & $12.0(2.6)$ & $2.07(0.4)$ & $0.523(0.2)$ & $1.10(0.2)$ \\
\hline$C_{43}$ & $129(07)$ & $217(0.3)$ & $0.648(0.2)$ & $1.31(0.3)$ \\
\hline $\mathrm{C}_{14}$ & $13.0(0.2)$ & $2.50(0.4)$ & $0.731(0.3)$ & $1.02(0.3)$ \\
\hline$C_{4}$ & 13107 & $2.60(03)$ & $0.579(0.1)$ & $0.950(0) 3\}$ \\
\hline$C_{16}$ & $11.9(1.3)$ & $2.40(0.4)$ & $0.541(0.1)$ & $0.722(0.2)$ \\
\hline $\mathrm{C}_{1}+\mathrm{Pr}$ & $37.9(3.3)$ & $10.0(0.8)$ & $1.89(0.4)$ & $0.030(0.1)$ \\
\hline $\mathrm{C}_{18}$ & $9.09(1.3)$ & $2.03(0.2)$ & $0.476(0.1)$ & $0.488(0.2)$ \\
\hline Phy & $13.0(15)$ & $4.04(0.4)$ & $0.808(0,2)$ & ND. \\
\hline $\mathrm{C}_{19}$ & $7.50(0.9)$ & $1.83(0.3)$ & $0.524(0.1)$ & $0.501(0.1)$ \\
\hline$C_{20}$ & $6.33(02)$ & $158(0.3)$ & $0456(004)$ & $0.616(0.2)$ \\
\hline $\mathrm{C}_{21}$ & $5.42(0.09)$ & $1.44(0.3)$ & $0.434(0.07)$ & $0.535(0.2)$ \\
\hline $\mathrm{C}_{22}$ & $436(02)$ & $134(0.2)$ & $0.401(0.07)$ & $0.521(0.2)$ \\
\hline $\mathrm{C}_{23}$ & $4.18(0.2)$ & $1.36(0.2)$ & $0.424(0.09)$ & $0.494(0.1)$ \\
\hline $\mathrm{C}_{24}$ & $4.20(0.3)$ & $(1.58(0.1)$ & $0.519(0.09)$ & $6.4476 .1)$ \\
\hline $\mathrm{C}_{25}$ & $3.68(0.5)$ & $1.55(0.3)$ & $0.496(0.09)$ & $0.418(0.09)$ \\
\hline$C_{26}$ & $3.15(0.4)$ & $1.62(0.4)$ & $0.505(0.1)$ & 0.4770 .11 ? \\
\hline $\mathrm{C}_{27}$ & $1.99(0.1)$ & $1.05(0.3)$ & $0.351(0.05)$ & $0.339(0.1)$ \\
\hline $\mathrm{C}_{28}$ & $(1.90(0.03)$ & $0.872(006)$ & $0.350(0.1)$ & $0321(0.08)$ \\
\hline $\mathrm{C}_{29}$ & $1.53(0.2)$ & $0.664(0.05)$ & $0.231(0.04)$ & $0.305(0.06)$ \\
\hline $\mathrm{C}_{20}$ & $1.53(0.3)$ & $0.754(0.04)$ & $(0.223(0.03)$ & $0.267(0.07)$ \\
\hline $\mathrm{C}_{31}$ & $1.30(0.3)$ & $0.877(0.07)$ & $0.245(0.08)$ & $0.220(0.08)$ \\
\hline $\mathrm{C}_{32}$ : & $0965(02)$ & $0,71,(0.04)$ & $0.187(0.06)$ & $0.187(0.06)$ \\
\hline $\mathrm{C}_{32}$ & $0.876(0.2)$ & $0.694(0.1)$ & $0.165(0.04)$ & ND. \\
\hline
\end{tabular}

Table 23. Recovery of aliphatic hydrocarbons (S.D.) from triplicate stepwise HTSFE of Posidonia shale 


\begin{tabular}{|c|c|c|c|c|}
\hline Comp & $\begin{array}{c}50^{\circ} \mathrm{C} \\
(\mathrm{ppm})(\mathrm{S} . \mathrm{D} .)\end{array}$ & $\begin{array}{c}150^{\circ} \mathrm{C} \\
(\mathrm{ppm})(\text { S.D. })\end{array}$ & $\begin{array}{c}250^{\circ} \mathrm{C} \\
(\mathrm{ppm})(\mathrm{S} . \mathrm{D} .)\end{array}$ & $\begin{array}{c}350^{\circ} \mathrm{C} \\
(\mathrm{ppm})(\text { S.D. })\end{array}$ \\
\hline Naphthalene & $12.8(1.3)$ & $2.26(0.8)$ & $3.99(0.6)$ & $6.78(2.1)$ \\
\hline C. $1 \mathrm{MN}$ & $(5.11(1.2)$ & $3.51(0.6)$ & $5.23(1.5)$ & $13.5(3.1)$ \\
\hline $\mathrm{C}-2 \mathrm{MN}$ & $13.9(1.1)$ & $4.77(0.7)$ & $4.66(1.3)$ & $8.19(1.7)$ \\
\hline roul MN & $290(16)$ & $828(12)$ & $989(27)$ & $212(4.8)$ \\
\hline $1-E, 2-E N$ & $2.84(0.3)$ & $0.976(0.1)$ & $1.30(0.3)$ & $3.09(0.6)$ \\
\hline $2,6,2,7 \mathrm{DWN}$ & $4.36(0)$ & $127(02)$ & $251(06)$ & $865(1.9)$ \\
\hline 1,$3 ; 1,7-\mathrm{DMN}$ & $6.07(0.5)$ & $2.26(0.2)$ & $3.07(0.8)$ & $10.0(1.9)$ \\
\hline $1,6-\mathrm{ONN}$ & $6.8(1.1)$ & $2,10(02)$ & $32(06)$ & $6,43(08)$ \\
\hline$*$ & $4.85(0.4)$ & $1.81(0.3)$ & $2.21(0.4)$ & $5.49(0.9)$ \\
\hline $18 \mathrm{DNN}$ & $206(0.2)$ & $0.830(02)$ & $1,06(02)$ & $2.66(0.3)$ \\
\hline Total DMN & $26.7(2.7)$ & $9.84(0.9)$ & $13.5(2.6)$ & $36.3(6.3)$ \\
\hline $1,3,7 . \mathrm{TMN}$ & $2.260 .4)$ & 1.100011 & $133(03)$ & $686(14)$ \\
\hline $1,3,6-\mathrm{TMN}$ & $3.42(0.6)$ & $1.64(0.2)$ & $1.59(0.4)$ & $7.11(1.6)$ \\
\hline $1,4,6,1,3,5-1 \mathrm{MN}$ & $2.18(0.3)$ & $1.27(007)$ & $1.1503)$ & $483(09)$ \\
\hline $2,3,6-\mathrm{TMN}$ & $1.30(0.1)$ & $0.527(0.07)$ & $0.787(0.2)$ & $5.12(0.8)$ \\
\hline 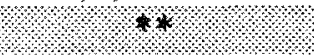 & $3.17(04)$ & $158(0.05)$ & $1.86(0,4)$ & $8.78(1.5)$ \\
\hline $1,2,5-\mathrm{TMN}$ & $1.45(0.1)$ & $0.812(0.1)$ & $0.711(0.1)$ & $1.60(0.1)$ \\
\hline Total TMNN & $13.8(1.9)$ & $693(0.4)$ & $1,43(1)$ & $34.316 .1)$ \\
\hline
\end{tabular}

Table 24. Recovery of naphthalene and alkyl-naphthalenes (aromatic hydrocarbons) (S.D.) from triplicate stepwise HT-SFE of Posidonia shale 


\begin{tabular}{|c|c|c|c|c|}
\hline Comp & $\begin{array}{c}50^{\circ} \mathrm{C} \\
(\mathrm{ppm})(\mathrm{S} . \mathrm{D} .)\end{array}$ & $\begin{array}{c}150^{\circ} \mathrm{C} \\
(\mathrm{ppm})(\mathrm{S} . \mathrm{D} .)\end{array}$ & $\begin{array}{c}250^{\circ} \mathrm{C} \\
(\mathrm{ppm})(\mathrm{S} . \mathrm{D} .)\end{array}$ & $\begin{array}{c}350^{\circ} \mathrm{C} \\
(\mathrm{ppm})(\mathrm{S} . \mathrm{D} .)\end{array}$ \\
\hline Phenanthrene & $2.30(0.1)$ & $0.932(0.2)$ & $1.59(0.2)$ & $3.58(0.7)$ \\
\hline Anthracene: & ND. & ND & N D & $1.81(0.4)$ \\
\hline 3-MP & $0.709(0.08)$ & $0.394(0.05)$ & $0.509(0.09)$ & $2.29(0.4)$ \\
\hline $2,1 \mathrm{P}$ & $0.883(02)$ & $0.46 \%(0.05)$ & $0.619(0.1)$ & $280(0.5)$ \\
\hline 2-MA & N.D. & N.D. & N.D. & $2.21(0.9)$ \\
\hline $9-\mathrm{MP}$ & $(.07(0.2)$ & $0.63 .5(0.05)$ & 06720.11. & $2.710 .5)$ \\
\hline 1-MP & $1.30(0.2)$ & $0.825(0.07)$ & $1.48(0.1)$ & N.D. \\
\hline$(1-1 \mathrm{P}+1, \mathrm{~N} \mathrm{X}$ & $\mathrm{ND}$. & ND. & ND & $503(1 / 4)$ \\
\hline 9-MA & N.D. & N.D. & N.D. & $0.667(0.3)$ \\
\hline Total MP & $397(08)$ & $2,32(0.08)$ & $328(0.5)$ & No \\
\hline Total MP+MA & N.D. & N.D. & N.D. & $15.7(2.0)$ \\
\hline Total DMP & $285(0.6)$ & $185(02)$ & $2.16(14)$ & No \\
\hline$*$ & N.D. & N.D. & N.D. & $21.0(4.6)$ \\
\hline
\end{tabular}

: Total DMP+DMA

Table 25. Recovery of Phenanthrene, anthracene, alkyl-phenanthrenes and alkylanthracenes (aromatic hydrocarbons) (S.D.) from triplicate stepwise HT-SFE of Posidonia shale 
varied for different types of hydrocarbons and different extraction temperatures. As seen in Figures 28, 29 and 30, most hydrocarbons showed high recoveries at $50^{\circ} \mathrm{C}$ followed by decreases in recoveries at $150^{\circ} \mathrm{C}$ and $250^{\circ} \mathrm{C}$ with an increment at $350^{\circ} \mathrm{C}$ (especially for most aromatic hydrocarbons). However, whilst aliphatic hydrocarbons showed a minimum at $250^{\circ} \mathrm{C}$, the aromatics reached the minimum at $150^{\circ} \mathrm{C}$. In addition, the ratio of extracted compounds at $50^{\circ} \mathrm{C}$ vs $350^{\circ} \mathrm{C}(50 / 350)$ was larger than one for the aliphatics, naphthalene, and methyl-naphthalenes, but is much below unity for other aromatics. The ratio of $50 / 350$ also decreased with increasing number of aromatic rings and with increasing degree of alkylation. In addition, anthracene and alkyl-anthracenes were only released at $350^{\circ} \mathrm{C}$. As mentioned in section 1.2 , the recovery of the analytes from solid matrices depends on solubility and diffusivity of analytes in a solvent or fluid, and particularly, the competition between the affinity of the analytes for the matrix (OM in this study) and for solvent or fluid, and the speciation of analytes. In general, the hydrocarbons obtained in the $50^{\circ} \mathrm{C}$ fraction of stepwise HT-SFE are presumably those weakly associated with matrix and the main reason for their release is solubility. The density of a supercritical fluid (the solubility of analytes in supercritical fluid) decreases with the increase of the temperature under the same pressure. Therefore, compared to the extractions performed at other temperatures, the solubility of analytes in supercritical $\mathrm{CO}_{2}$ (at $5000 \mathrm{psi}$ ) at $50^{\circ} \mathrm{C}$ is the highest. A significant increase of recoveries at $350^{\circ} \mathrm{C}$ has definitely some connection with the thermally energy supply and the advantages of supercritical fluid extraction. As mentioned before, hydrocarbons in geological samples were produced by pyrolysis of kerogen. Therefore, it is understandable that many of them 


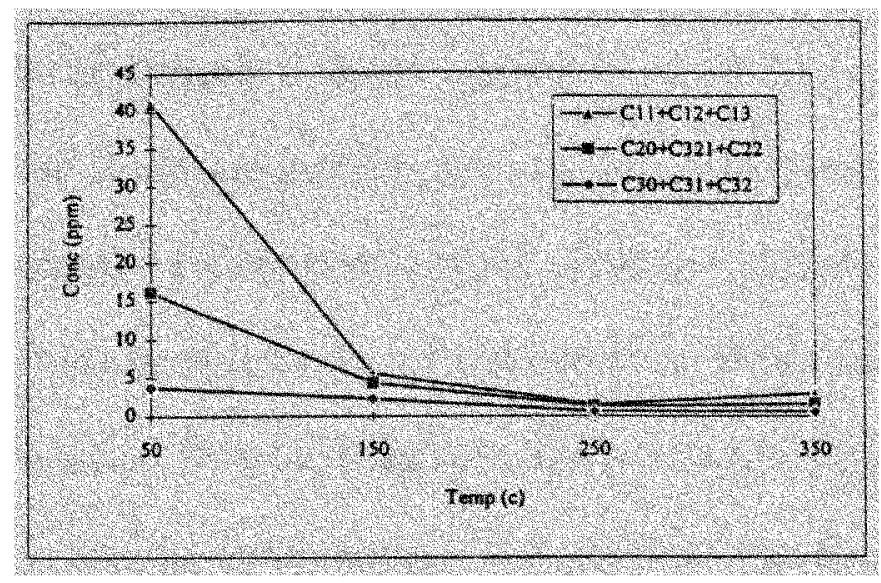

Figure 28. Aliphatic hydrocarbons recovered (ppm) from HT-SFE of Posidonia shale vs. temperature

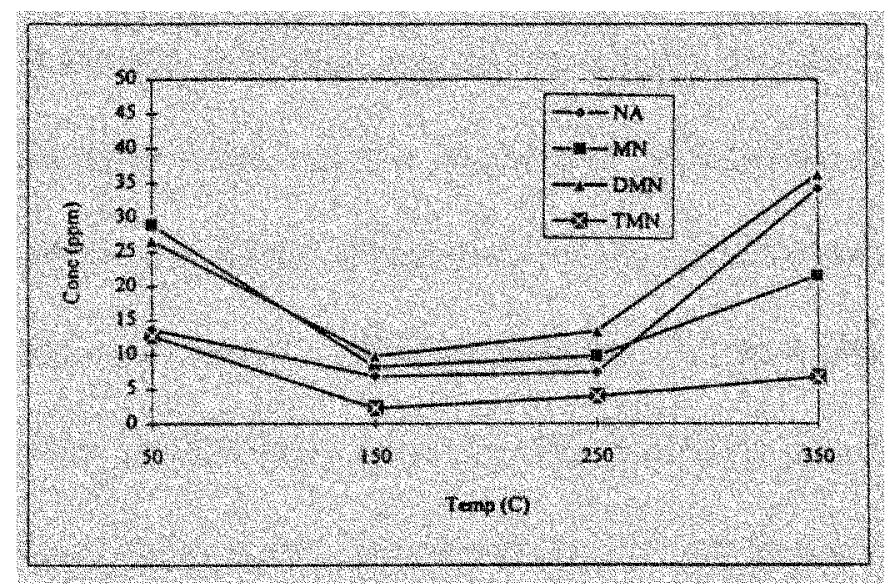

Figure 29. Naphthalene and alkyl-naphthalenes recovered (ppm) from HT-SFE of Posidonia shale vs. temperature

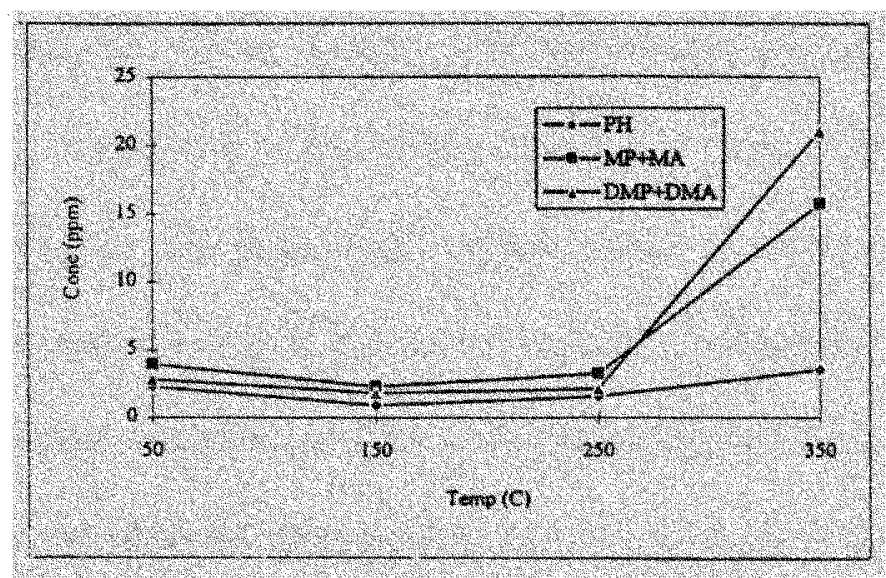

Figure 30. Phenanthrene alkyl-phenanthrenes and alkyl-anthracenes recovered (ppm) from HT-SFE of Posidonia shale vs. temperature 
are strongly associated with and 'trapped' within internal voids of polymeric structures of OM. With the help of thermally induced rearrangement of the macromolecular OM (presumably occurring at high temperature), and the efficient penetration of supercritical fluid into the open porous and the high diffusion coefficient of analytes in supercritical fluid, those hydrocarbons strongly associated with $\mathrm{OM}$ were able to overcome interactions with $\mathrm{OM}$ and be released. Those hydrocarbons 'trapped' within polymeric structure of OM were, therefore, (for the same reasons) accessible for the supercritical fluid and extracted. The reason that the ratio of extracted compounds at $50^{\circ} \mathrm{C}$ vs $350^{\circ} \mathrm{C}$ was more than one for aliphatics and less than one for aromatics, and the fact that the ratio decreased for aromatics with the increase the number of aromatic rings and degree of alkylation, is most likely due to the strong interactions of those hydrocarbons with the matrix. As mentioned in section 9.1., the more aromatic, the more planar. Therefore, the more surface areas were available for interacting with the matrix and the more difficult to be released. Additionally, as these compounds became alkylated, they become more difficult to recover from the matrix. However, due to the increased desorption kinetics at high temperature and the higher volatility of these aromatics, they were able to be efficiently released. Anthracene and alkyl-anthracenes must either have stronger interactions with $\mathrm{OM}$ in sediments than phenanthrenes, or have a different origin, therefore, they were only released at high temperature. Recently Smith et al (1995) have suggested that significant increment of alkyl-aromatics during heating experiments (66hrs) at $350^{\circ} \mathrm{C}-400^{\circ} \mathrm{C}$ is the result of syntheses of alkyl-aromatics by the reaction of parent aromatic hydrocarbons (naphthalene and phenanthrene) with n-alkanes (Smith et al., 
1995). Investigation on methylation is under way in our research group in order to find out whether or not this is another reason that the ratio of $50 / 350$ decreases with the increase of the number of aromatic ring and the degree of alkylation.

To further evaluate the effect of thermal energy supply on the recovery of hydrocarbons, Posidonia shale was subjected to thermodesorption. Average results of the recovery of aliphatic, aromatic hydrocarbons from each fraction of triplicate thermodesorption of Posidonia shale are summarized in Tables 26, 27 and 28. No biomarkers were recovered from thermodesorption. The recovery of analytes by thermodersorption is mainly due to the volatilizing the analytes on the basis of the thermal energy supply. It is apparent that, whilst there was no recovery of any analytes at extraction temperature of $50^{\circ} \mathrm{C}, \mathrm{C}_{10}-\mathrm{C}_{15}$ of aliphatics and naphthalene showed increased recoveries at $150^{\circ} \mathrm{C}$. At extraction temperature of $250^{\circ} \mathrm{C}$, all naphthalenes and phenanthrenes, except dimethyl-phenanthrenes, were detected but only aliphatics up to $C_{20}$ were detected. Dimethyl-phenanthrenes and aliphatics of $C_{21}$ up to $C_{29}$ started to be released only at $350^{\circ} \mathrm{C}$. No $\mathrm{C}_{30}-\mathrm{C}_{33}$ of aliphatics or any biomarkers were released by thermodesorption. Figures 31,32 and 33 illustrate aliphatics and aromatics recovered from thermodesoprtion of Posidonia shale vs. temperature. All these results can be explained by the different boiling point, different molecular weight of these analytes and their interaction with the matrix. The lower the boiling point (the lower the molecular weight), the less the thermal energy needed for the release. For real geological samples, the thermal energy supplied in thermodesorption has to be high enough to overcome the 


\begin{tabular}{|c|c|c|c|c|}
\hline Comp & $\begin{array}{c}50^{\circ} \mathrm{C} \\
(\mathrm{ppm})(\mathrm{S} . \mathrm{D} .)\end{array}$ & $\begin{array}{c}150^{\circ} \mathrm{C} \\
(\mathrm{ppm})(\text { S.D. })\end{array}$ & $\begin{array}{c}250^{\circ} \mathrm{C} \\
(\mathrm{ppm})(\mathrm{S} . \mathrm{D} .)\end{array}$ & $\begin{array}{c}350^{\circ} \mathrm{C} \\
(\mathrm{ppm})(\mathrm{S.D} .)\end{array}$ \\
\hline $\mathrm{C}_{10}$ & N.D. & $8.13(2.8)$ & $3.37(1.3)$ & $0.830(0.1)$ \\
\hline$C_{1}$. & ND. & $637(30)$ & $1,8(06)$ & $126(003)$ \\
\hline $\mathrm{C}_{12}$ & N.D. & $6.51(2.7)$ & $8.08(3.8)$ & $1.14(0.1)$ \\
\hline C.13. & No. & $3.70(1.9)$ & $9.90(2.5)$ & $131(0,5)$ \\
\hline $\mathrm{C}_{14}$ & N.D. & $1.67(0.9)$ & $9.60(1.4)$ & $1.42(0.4)$ \\
\hline $\mathrm{C}_{13}$ & $\mathrm{No}$ & $07,22(04)$ & $904(14)$ & $201(08)$ \\
\hline $\mathrm{C}_{16}$ & N.D. & N.D. & $7.40(1.9)$ & $2.50(0.9)$ \\
\hline$C_{1}, P_{F}$ & ND. & ND & $899(39)$ & $3.30(0,8)$ \\
\hline $\mathrm{C}_{18}$ & N.D. & N.D. & $3.48(1.3)$ & $3.04(0.3)$ \\
\hline Phy: & ND & No. & $1.54(07)$ & $0766(0)$ \\
\hline $\mathrm{C}_{19}$ & N.D. & N.D. & $2.37(1.2)$ & $2.53(0.7)$ \\
\hline$C_{2}$ & No & N D & $1,35(0.6)$ & $190(0.4)$ \\
\hline $\mathrm{C}_{21}$ & N.D. & N.D. & N.D. & $1.53(0.3)$ \\
\hline $\mathrm{C}_{22}$ & No & No & ND & $120(03)$ \\
\hline $\mathrm{C}_{23}$ & N.D. & N.D. & N.D. & $0.914(0.07)$ \\
\hline $\mathrm{C}_{21}$ & N.D & N D D & ND & $0.702(0.2)$ \\
\hline $\mathrm{C}_{25}$ & N.D. & N.D. & N.D. & $0.821(0.5)$ \\
\hline$C_{26}$ & No & N10 & No. & $0.384(0.04)$ \\
\hline $\mathrm{C}_{27}$ & N.D. & N.D. & N.D. & $0.177(0.02)$ \\
\hline$C_{28}$ & ND. & ND. & $\mathrm{ND}$ & $0.115(0.04)$ \\
\hline $\mathrm{C}_{29}$ & N.D. & N.D. & N.D. & N.D. \\
\hline$C_{30}$ & ND. & No & ND & No \\
\hline $\mathrm{C}_{31}$ & N.D. & N.D. & N.D. & N.D. \\
\hline $\mathrm{C}_{32}$ & ND & No & N D & ND \\
\hline $\mathrm{C}_{33}$ & N.D. & N.D. & N.D. & N.D. \\
\hline
\end{tabular}

Table 26. Recovery of aliphatic hydrocarbons (S.D.) from triplicate thermodesorption of Posidonia shale 


\begin{tabular}{|c|c|c|c|c|}
\hline Comp & $\begin{array}{c}50^{\circ} \mathrm{C} \\
(\mathrm{ppm})(\mathrm{S} . \mathrm{D} .)\end{array}$ & $\begin{array}{c}150^{\circ} \mathrm{C} \\
\text { (ppm)(S.D.) }\end{array}$ & $\begin{array}{c}250^{\circ} \mathrm{C} \\
(\mathrm{ppm})(\mathrm{S.D} .)\end{array}$ & $\begin{array}{c}350^{\circ} \mathrm{C} \\
(\mathrm{ppm}) \text { (S.D.) }\end{array}$ \\
\hline Naphthalene & N.D. & $2.20(0.9)$ & $14.7(7.8)$ & $5.57(1.3)$ \\
\hline C. . MN & No & ND. & $190(3,6)$ & $121(31)$ \\
\hline $\mathrm{C}-2 \mathrm{MN}$ & N.D. & N.D. & $15.2(4.1)$ & $7.27(2.1)$ \\
\hline Total $\mathrm{MN}$ & ND & $\mathrm{ND}$ & 34207 ) & $19,3(5,2)$ \\
\hline $1-E, 2-E N$ & N.D. & N.D. & $3.40(0.8)$ & $3.07(0.6)$ \\
\hline $2,6,2,7-0 \mathrm{MN}$ & No & $\mathrm{No}$ & $5.63(1.6)$ & $998(19)$ \\
\hline 1,$3 ; 1,7-\mathrm{DMN}$ & N.D. & N.D. & $6.43(2.0)$ & $11.0(2.2)$ \\
\hline . 6 DMN & ND & No. & $627(20)$ & $895(08)$ \\
\hline * & N.D. & N.D. & $4.46(1.3)$ & $6.90(0.9)$ \\
\hline $1,8-\mathrm{DMN}$ & No & No & $2.16(0.6)$ & $3.07(0)$ \\
\hline Total DMN & N.D. & N.D. & $28.4(8.3)$ & $42.9(6.4)$ \\
\hline $1,3,7, \mathrm{TMN}$ & No. & ND. & $1.62(0.6)$ & $6.95(1.0)$ \\
\hline $1,3,6-\mathrm{TMN}$ & N.D. & N.D. & $1.28(0.5)$ & $7.97(0.5)$ \\
\hline $1,4,6,1,3,5-1 \mathrm{MN}$ & $\mathrm{ND}$. & $\mathrm{NO}$ & $103(0.4)$ & $8.40(0.2)$ \\
\hline $2,3,6-\mathrm{TMN}$ & N.D. & N.D. & $0.60(0.2)$ & $5.43(0.5)$ \\
\hline 1\% & No. & $\mathrm{ND}$. & $1,65(07)$ & $110(65)$ \\
\hline $1,2,5-\mathrm{TMN}$ & N.D. & N.D. & $0.662(0.3)$ & $2.42(0.4)$ \\
\hline Total TMN & N. D. & ND & $6.86(2.7)$ & $39.2(2.4)$ \\
\hline
\end{tabular}

Table 27. Recovery of naphthalene and alkyl-naphthalenes (aromatic hydrocarbons) (S.D.) from thermodesorption of Posidonia shale 


\begin{tabular}{|c|c|c|c|c|}
\hline Comp & $\begin{array}{c}50^{\circ} \mathrm{C} \\
(\mathrm{ppm})(\mathrm{S} . \mathrm{D} .)\end{array}$ & $\begin{array}{c}150^{\circ} \mathrm{C} \\
(\mathrm{ppm})(\mathrm{S} . \mathrm{D} .)\end{array}$ & $\begin{array}{c}250^{\circ} \mathrm{C} \\
(\mathrm{ppm})(\mathrm{S} . \mathrm{D} .)\end{array}$ & $\begin{array}{c}350^{\circ} \mathrm{C} \\
\text { (ppm)(S.D.) }\end{array}$ \\
\hline Phenanthrene & N.D. & N.D. & $2.27(0.9)$ & $5.30(0.3)$ \\
\hline Anthracene & No & $\mathrm{NO}$ & $\mathrm{ND}$ & $250(03)$ \\
\hline 3-MP & N.D. & N.D. & $0.412(0.2)$ & $2.98(0.02)$ \\
\hline $2-\mathrm{MP}$ & No & $1 \mathrm{p}$ & $0,35(02)$ & $3,45(02)$ \\
\hline 2-MA & N.D. & N.D. & N.D. & $2.49(0.6)$ \\
\hline $9 . \mathrm{MP}$ & No & No & $0.449(02)$ & $367(0.6)$ \\
\hline 1-MP & N.D. & N.D. & $0.580(0.2)$ & N.D. \\
\hline ( $\mathrm{MP}+1 / \mathrm{MA}$ & $\mathrm{NO}$ & $\mathrm{No}$ & $\mathrm{ND}$ & $702(19)$ \\
\hline 9-MA & N.D. & N.D. & N.D. & $0.787(1.4)$ \\
\hline Tatal MP & $\mathrm{No}$ & ND & 179088 & 100 \\
\hline Total MP+MA & N.D. & N.D. & N.D. & $20.4(2.7)$ \\
\hline Total DMP & No & No & $1 \mathrm{DO}$ & $\mathrm{NO}$ \\
\hline$*$ & N.D. & N.D. & N.D. & $19.9(0.2)$ \\
\hline
\end{tabular}

Table 28. Recovery of phenanthrene, anthracene, alkyl-phenanthrenes and alkylanthracenes (aromatic hydrocarbons) (S.D.) from thermodesorption of Posidonia shale 


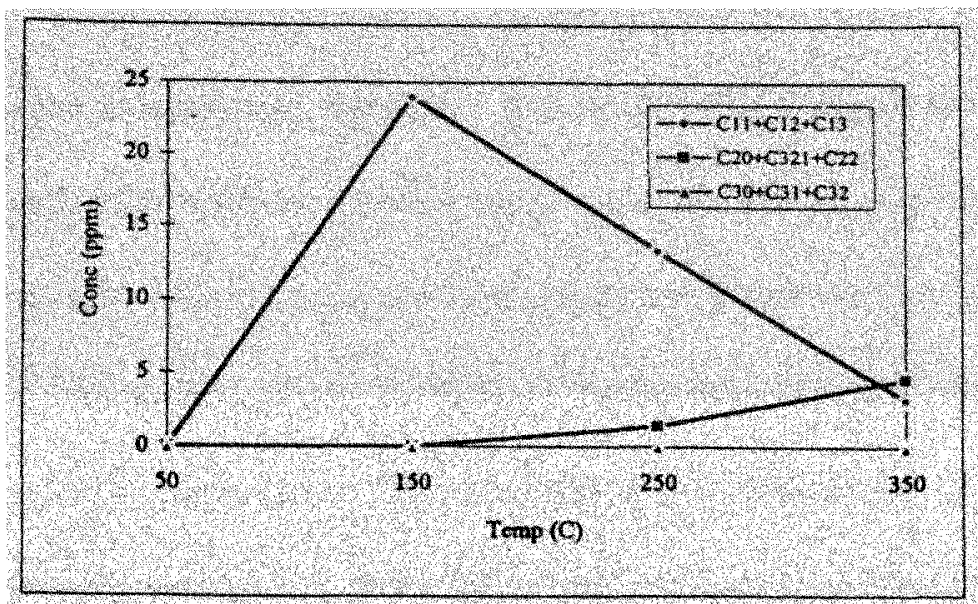

Figure 31. Aliphatic hydrocarbons recovered $(\mathrm{ppm})$ from thermodesorption of Posidonia shale vs. temperature

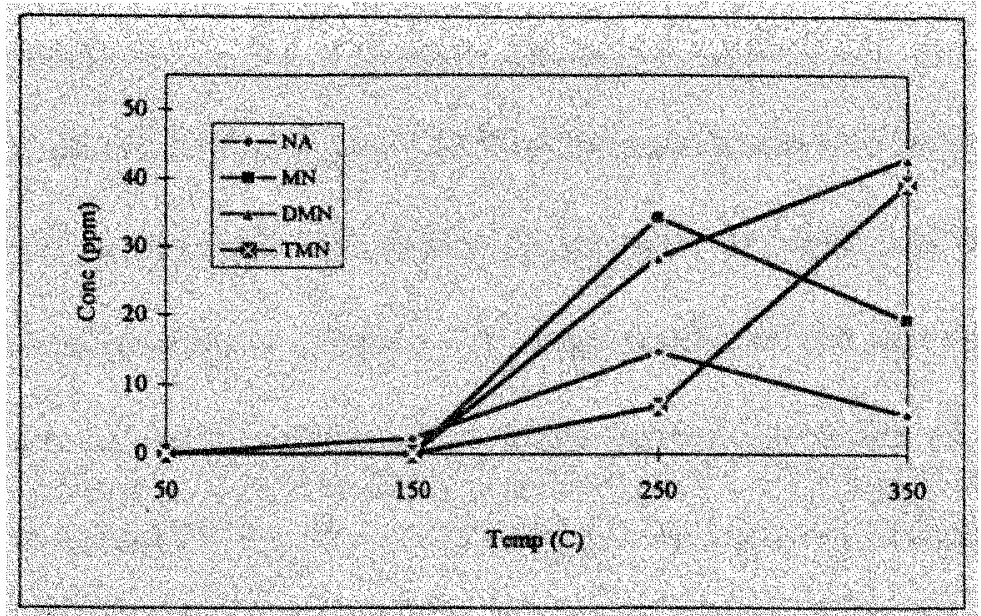

Figure 32. Naphthalene and alkyl-naphthalenes recovered (ppm) from thermodesorption of Posidonia shale vs. temperature

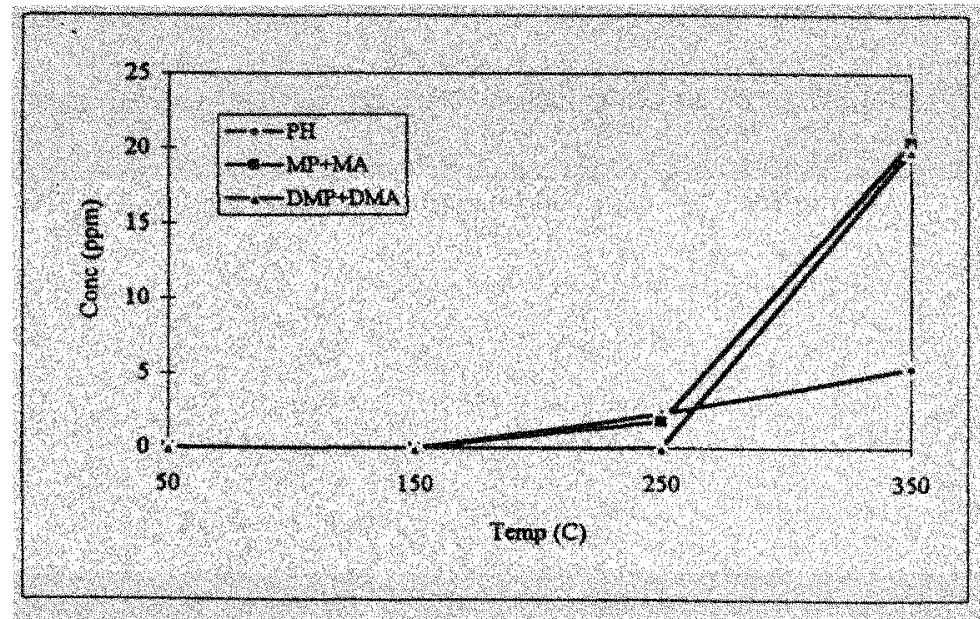

Figure 33. Phenanthrene alkyl-phenanthrenes and alkyl-anthracenes recovered (ppm) from thermodesorption of Posidonia shale vs. temperature 
interactions between analytes and matrices. Similar to SFE, a significant increment of recovery of aromatic hydrocarbons (except naphthalene and methyl-naphthalenes) at high temperature, especially, with the increase of aromatic rings and the degree of alkylation, was observed for thermodesorption. In addition, anthracene and alkyl-anthracenes were only observed at $350^{\circ} \mathrm{C}$ fraction for thermodesorption as well as for HT-SFE. It was confirmed that thermal energy has more effect on aromatic hydrocarbons due to their interaction with matrices and lower volatility.

Soxhlet extraction is the traditional extraction method for the preparation of geological sample for GC/MS analysis. The Posidonia shale was also subjected to Soxhlet extraction in order to evaluate the effect of stepwise HT-SFE on the recovery of hydrocarbons in real geological samples. Average results of the recovery of aliphatic, aromatic hydrocarbons and biomarkers from single Soxhlet extraction of Posidonia shale are summarized in Tables $29,30,31,32,33$ and 34 . The recovery of analytes by Soxhlet extraction is solely due to dissolving the analytes in the solvent used. Since Soxhlet extraction can only be performed at low temperature (the boiling point of the solvent) and the solvent only has access to the analytes adsorpted at the surface of the matrix, the analytes recovered by Soxhlet extraction may primarily be those having weak interactions with matrix. 


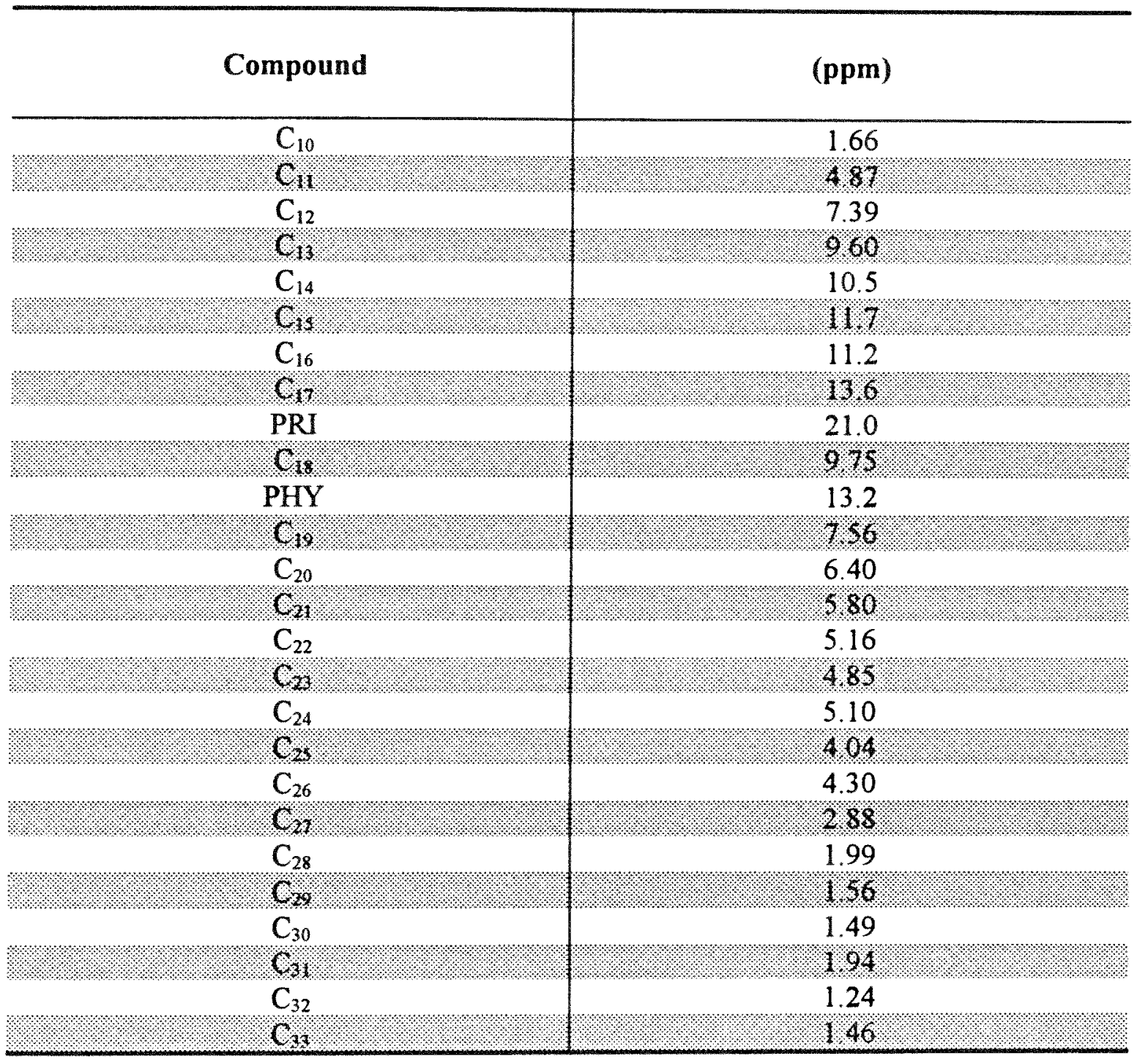

Table 29. Recovery of aliphatic hydrocarbons from single Soxhlet extraction of Posidonia shale 


\begin{tabular}{|c|c|}
\hline Compound & (ppm) \\
\hline Naphthalene & 10.7 \\
\hline C. MNO & 16.5 \\
\hline $\mathrm{C}-2 \mathrm{MN}$ & 14.8 \\
\hline Total MN & 313 \\
\hline $1-E, 2-E N$ & 3.24 \\
\hline $2,6,2,7,0 M M$ & 5,44 \\
\hline 1,$3 ; 1,7-\mathrm{DMN}$ & 7.92 \\
\hline $1.6 \mathrm{DMN}$ & $713 \%$ \\
\hline 1,$4 ; 1,3 ; 1,5-\mathrm{DMN}$ & 5.75 \\
\hline $1,8 . \mathrm{DNN}$ & 2.79 \\
\hline Total DMN & 32.3 \\
\hline $1,3,7, \mathrm{TMN}$ & 309 \\
\hline $1,3,6-\mathrm{TMN}$ & 3.68 \\
\hline $1,4,6,1,3,5-\mathrm{TMN}$ & 294 \\
\hline $2,3,6-T M N$ & 1.52 \\
\hline $1,2,7,1,6,7,1,2,6, \mathrm{TMN}$ & $4.10 \%$ \\
\hline $1,2,5-\mathrm{TMN}$ & 1.62 \\
\hline Total TMN & 160 \\
\hline
\end{tabular}

Table 30. Recovery of naphthalenes (aromatic hydrocarbons) from single Soxhlet extraction of Posidonia shale

\begin{tabular}{|c|c|}
\hline Compound & (ppm) \\
\hline Phenanthrene & 4.61 \\
\hline $.9-\mathrm{MP}$. & 1.35 \\
\hline 2-MP & 1.48 \\
\hline $9, \mathrm{MP}$ & 2.39 \\
\hline 1-MP & 2.29 \\
\hline Total MP & 172. \\
\hline Total DMP & 4.59 \\
\hline
\end{tabular}

Table 31. Recovery of phenanthrenes (aromatic hydrocarbons) from single Soxhlet extraction of Posidonia shale 


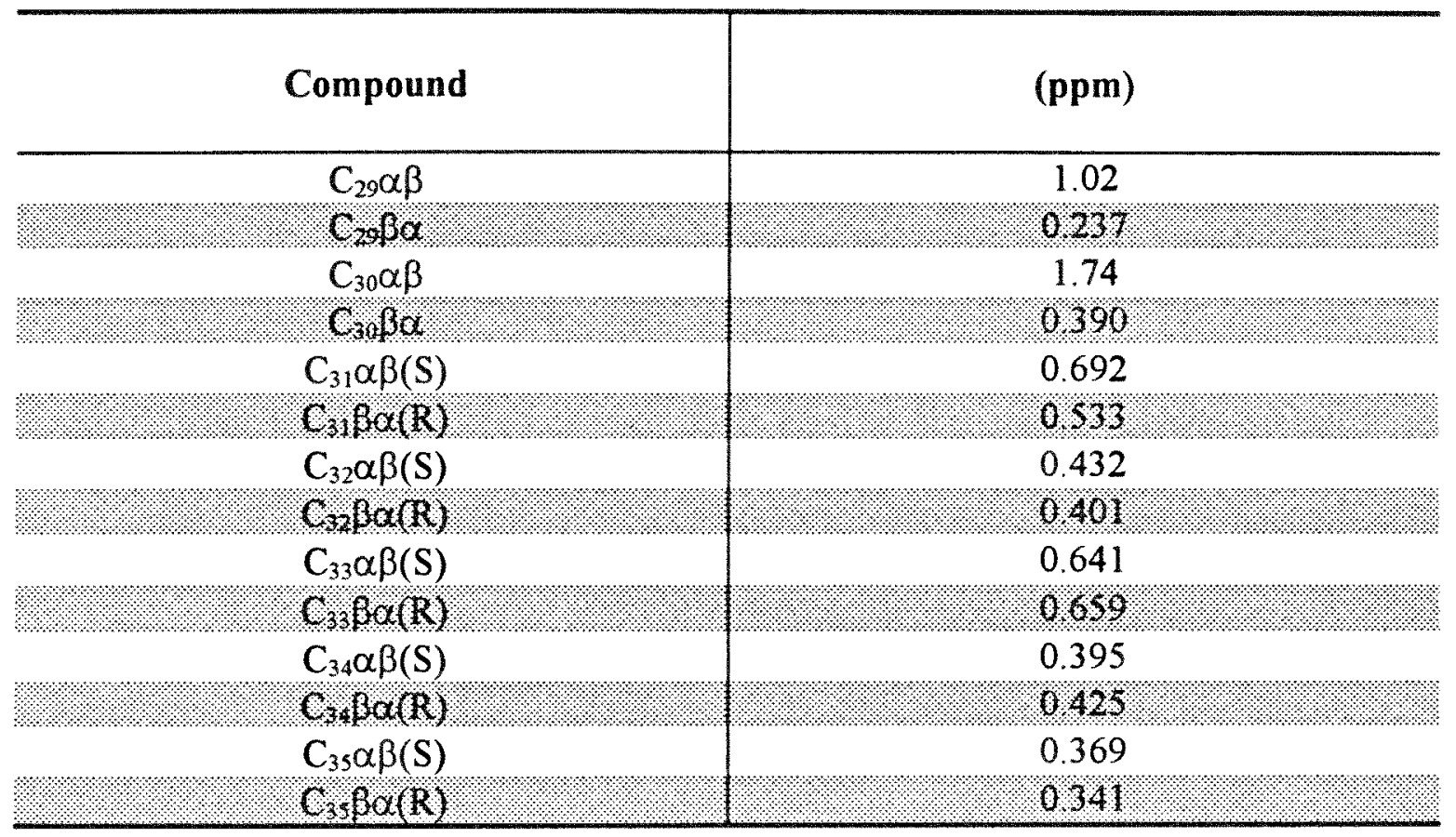

Table 32. Recovery of hopanes from single Soxhlet extraction of Posidonia shale 


\begin{tabular}{|c|c|}
\hline Compound & $(\mathbf{p p m})$ \\
\hline $5 \beta(\mathrm{H}) \mathrm{C}_{27}(20 \mathrm{~S})$ & 0.799 \\
\hline $3 \beta(H) C_{2}(20 R)$ & $1.0 s$ \\
\hline $5 \alpha(\mathrm{H}) \mathrm{C}_{27}(20 \mathrm{~S})+5 \beta(\mathrm{H}) \mathrm{C}_{28}(20 \mathrm{~S})$ & 2.86 \\
\hline \%:. & 5.59 . \\
\hline $5 \alpha(\mathrm{H}) \mathrm{C}_{29}(20 \mathrm{~S})$ & 1.90 \\
\hline $50(\mathrm{H}) \mathrm{C}_{28}(20 \mathrm{R})+5 \beta(\mathrm{H}) \mathrm{C}_{22}(20 \mathrm{R})$ & 2.95 . \\
\hline $5 \alpha(\mathrm{H}) \mathrm{C}_{29}(20 \mathrm{R})$ & 0.954 \\
\hline
\end{tabular}

*: $5 \alpha(\mathrm{H}) \mathrm{C}_{27}(20 \mathrm{R})+5 \alpha(\mathrm{H}) \mathrm{C}_{28}(20 \mathrm{~S})+5 \beta(\mathrm{H}) \mathrm{C}_{28}(20 \mathrm{R})+5 \beta(\mathrm{H}) \mathrm{C}_{28}(20 \mathrm{~S})$

Table 33. Recovery of monoaromatic steranes from single Soxhlet extraction of Posidonia shale

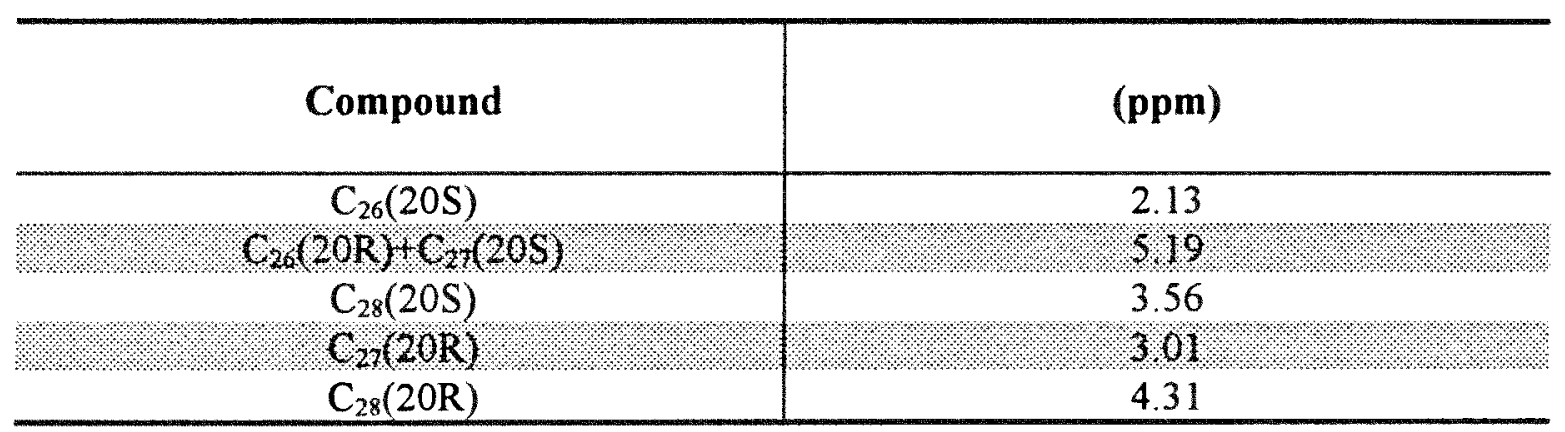

Table 34. Recovery of triaromatic steranes from single Soxhlet extraction of Posidonia shale 

extraction and thermodesorption

A better insight into the effect of thermal energy supply on HT-SFE can be obtained by comparing the recovery of hydrocarbons from thermodesorption and HTSFE, due to the fact that the recovery of analytes from thermodesorption is only achieved by thermal energy supply. Among all the analytes targeted in this project, relative low, medium and high molecular weight of aliphatic hydrocarbon $\left(C_{10-12}, C_{20-22}\right.$ and $C_{30-32}$ respectively), and the aromatic hydrocarbons, as well as the biomarkers described in section 9.2 were used for this study as individual class of analytes. The accummulative recoveries of these compounds by thermodesorption and HT-SFE (in triplicate) and the \% relative recovery from thermodesorption to recovery from SFE are shown in Table 35 . It is clear that the contribution of temperature (thermodesorption) on the recovery of hydrocarbons in geological samples by HT-SFE is highly dependent on the class, volatility and molecular weight of the analytes. As seen in Table 35, the contribution of the thermal effect on the recovery from HT-SFE for all classes of analytes was zero at $50^{\circ} \mathrm{C}$ and for the accumulative recovery between $50^{\circ} \mathrm{C}$ and $150^{\circ} \mathrm{C}$ was noticeable only for the most volatile compounds such as $\mathrm{C}_{10-12}$ and naphthalene. The effect of temperature on the recovery from HT-SFE reached $80 \%$ for low molecular weight and high volatile analytes, such as $\mathrm{C}_{10-12}$, naphthalene, alkyl-naphthalenes, phenanthrene, anthracene, alkylphenanthrenes and alkyl-anthracenes at accumulative recovery from $50^{\circ} \mathrm{C}-350^{\circ} \mathrm{C}$. For high molecular weight and non-volatile analytes, such as $\mathrm{C}_{30-33}$ and all biomarkers, the contribution of temperature was zero even with high temperature applied $\left(350^{\circ} \mathrm{C}\right)$. As 
seen in Figures 34,35 and 36 , as well as in Table 35, whilst the thermal effect decreased with the increase of molecular weight for aliphatic hydrocarbons, it increased with the increase of aromaticity and degree of alkylation for aromatic hydrocarbons. For example, the $\%$ relative recovery of thermodesorption (solely thermal effect) to HT-SFE for the accumulative recovery from $50^{\circ} \mathrm{C}-350^{\circ} \mathrm{C}$ decreased from 79 to 25 to 0 for $\mathrm{C}_{10-12}$, $\mathrm{C}_{20-22}$ and $\mathrm{C}_{30-\mathrm{C} 32}$ respectively (increase of molecular weight). For aromatic hydrocarbons, the comparison of the $\%$ relative recovery from $50^{\circ} \mathrm{C}-250^{\circ} \mathrm{C}$ to $50^{\circ} \mathrm{C}-350^{\circ} \mathrm{C}$ for naphthalene class (including alkyl-naphthalenes) and phenanthrene class (including alkylphenanthrenes) clearly showed that while the average $\%$ relative recovery increased from $50^{\circ} \mathrm{C}-250^{\circ} \mathrm{C}$ to $50^{\circ} \mathrm{C}-350^{\circ} \mathrm{C}$ was 20 for naphthalene class ( 2 aromatic rings), that was 56 for phenanthrene class ( 3 aromatic rings). On the other hand, for the same class with different alkylations, the average \% relative recovery increased from 27 to 69 to 71 for phenanthrene, methyl-phenanthrenes and dimethyl-phenanthrenes. For the naphthalene class, the same trend was observed. As discussed in section 9.2 , the most likely cause of these results is the different nature of these different classes of analytes (aliphatics or aromatics, the degree of aromaticity and the degree of alkylation) and the different intensity of interactions of these different classes of analytes with $O M$ (the available surface for interaction). For biomarkers, there was no thermal effect on the recovery from HT-SFE due to the fact that no biomarkers were recovered by thermodesorption. Based on the hypothesis of this part of the project, the thermally induced structural rearrangement of macromolecular OM of sediments should still occur during thermodesorption, the reason that no any biomarkers were recovered is, therefore, most 


\begin{tabular}{|c|c|c|c|c|c|c|c|c|}
\hline Comp & \multicolumn{2}{|c|}{$\begin{array}{c}50^{\circ} \mathrm{C} \\
\text { Thermo. SFE }\end{array}$} & \multicolumn{2}{|c|}{$\begin{array}{c}50^{\circ} \mathrm{C}+150^{\circ} \mathrm{C} \\
\text { Thermo. SFE }\end{array}$} & \multicolumn{2}{|c|}{$50^{\circ} \mathrm{C}+150^{\circ} \mathrm{C}+250^{\circ} \mathrm{C}$} & \multicolumn{2}{|c|}{ Total (4 fractions) } \\
\hline $\mathrm{C}_{10}+\mathrm{C}_{11}+\mathrm{C}_{12}$ & $0(0)$ & 41.1 & $24.0(51)$ & 467 & $37.4(77)$ & 48.3 & $40.6(79)$ & 51.3 \\
\hline $\mathrm{C}_{20}+\mathrm{C}_{2}+\mathrm{C}_{22}$ & $0(0)$ & 161 & $0(0)$ & 205 & $1 / 35(6)$ & 218 & $598(25)$ & 235 \\
\hline $\mathrm{C}_{30}+\mathrm{C}_{31}+\mathrm{C}_{32}$ & $0(0)$ & 3.14 & $0(0)$ & 5.42 & $0(0)$ & 6.02 & $0(0)$ & 6.43 \\
\hline Naplithalene & $0(0)$ & 128 & $220(15)$ & 151 & $169(88)$ & 191 & $22,8(87)$ & 259 \\
\hline$M-N A s^{(b)}$ & $0(0)$ & 29.0 & $O(0)$ & 37.3 & $34.2(72)$ & 47.2 & $53.5(78)$ & 68.9 \\
\hline ONANAS & $0(0)$ & 267 & $0(\theta)$ & 36.5 & $28.4(57)$ & 500 & $713(83)$ & 86.3 \\
\hline $\mathrm{TM}^{-N A s^{(b)}}$ & $0(0)$ & 13.8 & $0(0)$ & 20.7 & $6.86(24)$ & 28.1 & $46.1(74)$ & 62.4 \\
\hline Plenaminrene & $0(0)$ & 230 & $0(0)$ & 123 & $227(47)$ & 4.82 & $158(74)$ & $102^{\circ}$ \\
\hline $\mathrm{M}-\mathrm{PH} \mathrm{s}^{(\mathrm{b})}$ & $0(0)$ & 3.97 & $0(0)$ & 6.29 & $1.79(19)$ & 9.57 & $22.2(88)$ & $25.3^{(\mathrm{d})}$ \\
\hline DM-PHS & $O(0)$ & 2.85 & $0(0)$ & 470 & $0(0)$ & 6.86 & $19.9(71)$ & $27.9^{(0)}$ \\
\hline Hopanes $^{(b)}$ & $0(0)$ & 4.40 & $0(0)$ & 9.80 & $0(0)$ & 10.4 & $0(0)$ & 10.6 \\
\hline Monoaromatios ${ }^{2}$ ? & $(0)$ & 140 & $0(0)$ & 169 & $0(0)$ & 173 & $(0)$ & 17.3 \\
\hline Triaromatics $^{(b)}$ & $0(0)$ & 8.26 & $O(0)$ & 15.4 & $0(0)$ & 15.88 & $0(0)$ & 15.92 \\
\hline
\end{tabular}

(a): n-alkanes

(b): Total

(c): Total of phenanthrene and anthracene at $350^{\circ} \mathrm{C}$ extraction for Thermodesorption and SFE

(d): Total of methyl phenanthrene and methyl anthracene at $350^{\circ} \mathrm{C}$ extraction for Thermodesorption and SFE

(c): Total of dimethyl phenanthrene and dimethyl anthracene at $350^{\circ} \mathrm{C}$ extraction for Thermodesorption and SFE

Table 35. Accumulative recovery of hydrocarbons and biomarkers (ppm) from triplicate thermodersorption and SFE, as well as \% relative recovery from thermodesorption to recovery from SFE (in parenthesis) 


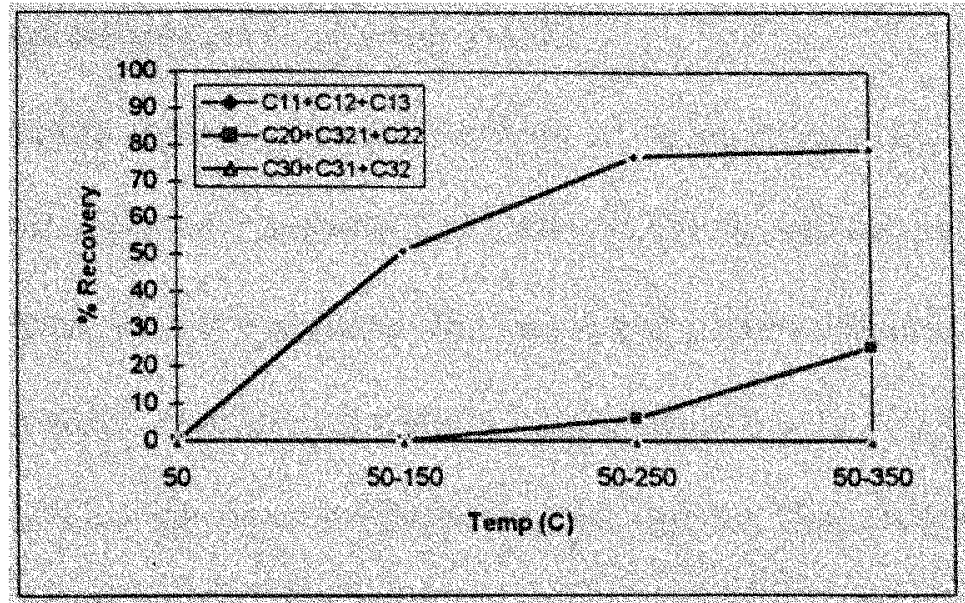

Figure 34. The \% recovery of aliphatic hydrocarbons from thermodesorption to recovery from HT-SFE vs. temperature

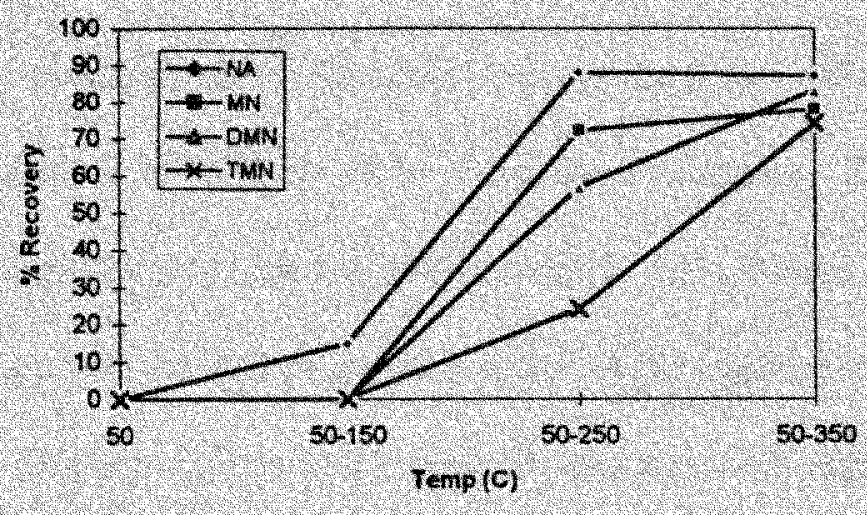

Figure 35. The $\%$ recovery of naphthalene and alkyl-naphthalenes from thermodesorption to recovery from HT-SFE vs. temperature

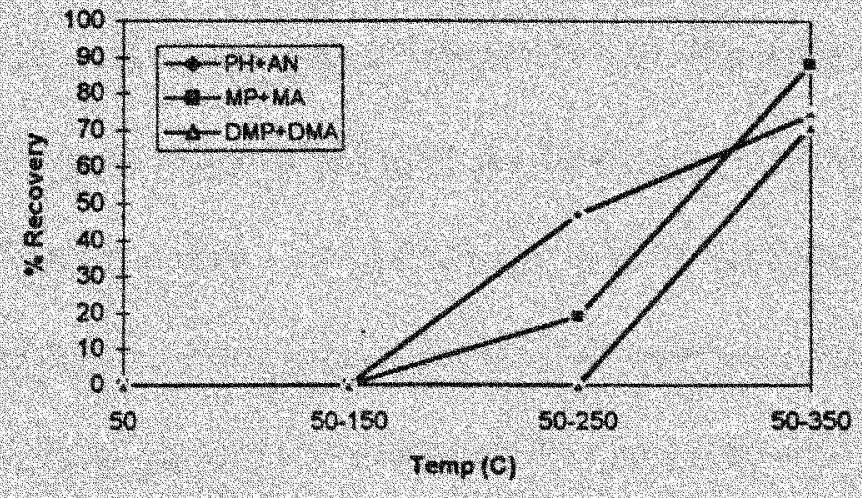

Figure 36. The \% recovery of phenanthrene, anthracene, alkyl-phenanthrenes and alkyl-anthracenes from thermodesorption to recovery from HT-SFE vs. temperature 
likely that these biomarkers are non-volatile compounds.

Table 36 illustrates the accumulative recovery of hydrocarbons and biomarkers from single Soxhlet extraction and triplicate HT-SFE and the \% relative recovery from HT-SFE to recovery from Soxhlet extraction. In general, compared to Soxhlet extraction, HT-SFE shows an increment in relative recoveries, ranging from 100 to $600 \%$ for all the analytes, depending on the temperature employed and the analytes. For most of analytes, the $\%$ relative recovery of $\mathrm{HT}-\mathrm{SFE}$ to Soxhlet reached 100 at either $50^{\circ} \mathrm{C}$ fraction or the combination of $50^{\circ} \mathrm{C}$ and $150^{\circ} \mathrm{C}$ fractions (the combination of $50^{\circ} \mathrm{C}$ to $250^{\circ} \mathrm{C}$ for phenanthrene and methyl-phenanthrenes). This clearly shows the higher efficiency of HTSFE vs. Soxhlet ( $1-2$ hours of HT-SFE vs $48 \mathrm{hr}$ of Soxhlet extraction). The reason for this observation is the combination of high solubility as well as the diffusion coefficient of the analytes in supercritical fluid and the penetration ability of the supercritical fluid. The successive SFE at high temperature clearly released the analytes with high interactions with the matrix due to the combined effect of the thermal energy supply (the main reason for low molecular weight and volatile compounds) and the advantages of SFE described before. Interestingly, the recoveries of biomarkers from HT-SFE of Posidonia shale is not as pronounced as those of regular aliphatic and aromatic hydrocarbons when compared to the recoveries from Soxhlet extraction. The different origins of aliphatic and aromatic hydrocarbons from that of biomarkers in geological samples may have played important roles for this observation. Since the aliphatic and aromatic hydrocarbons are produced by pyrolysis of highly polymeric kerogen, whereas biomarkers are deposited onto OM in the sediments originally, it is apprehensible that relatively less percent of biomarkers has 


\begin{tabular}{|c|c|c|c|c|c|}
\hline Comp & Soxhlet & $\begin{array}{l}50^{\circ} \mathrm{C} \\
\mathrm{SFE}\end{array}$ & $\begin{array}{c}150^{\circ} \mathrm{C} \\
\text { SFE }\end{array}$ & $\begin{array}{c}250^{\circ} \mathrm{C} \\
\text { SFE }\end{array}$ & $\begin{array}{c}350^{\circ} \mathrm{C} \\
\mathrm{SFE}\end{array}$ \\
\hline $\mathrm{C}_{10}+\mathrm{C}_{11}+\mathrm{C}_{12}{ }^{\text {(a) }}$ & 13.9 & $41.1(296)$ & $46.7(336)$ & $48.3(347)$ & $51.3(369)$ \\
\hline$C_{20}+C_{2}+C_{2}{ }^{\prime \prime}$ & 158 & $16.1(102)$ & $20.5(130)$ & $218(138)$ & $23 s(1,49)$ \\
\hline $\mathrm{C}_{30}+\mathrm{C}_{31}+\mathrm{C}_{32}{ }^{\text {(a) }}$ & 4.67 & $3.14(67)$ & $5.42(116)$ & $6.02(129)$ & $6.43(138)$ \\
\hline Naplbthalene & $10 \%$ & $(2,8(120)$ & $15.1441)$ & $19.1(179)$ & $259(242)$ \\
\hline $\mathrm{M}-\mathrm{Nas}^{(b)}$ & 31.3 & $29.0(93)$ & $37.3(191)$ & $47.2(151)$ & $68.9(220)$ \\
\hline DM-Nos & 32,3 & $267(82)$ & $365(113)$ & $50.0(155)$ & $86.3(267)$ \\
\hline TM-Nas ${ }^{\left({ }^{6}\right)}$ & 16.9 & $13.8(82)$ & $20.7(122)$ & $28.1(166)$ & $62.4(369)$ \\
\hline Pheranthene & 4.61 & $2.30(50)$ & $320(70)$ & $482(105)$ & $10.2(221) 19$ \\
\hline $\mathrm{M}-\mathrm{PHs}^{(\mathbf{b})}$ & 7.72 & $3.97(51)$ & $6.29(82)$ & $9.57(124)$ & $25.3(328)^{(\mathrm{d})}$ \\
\hline DM-PIS & 459 & $2.85(62)$ & $4.70(102)$ & $686(149)$ & $27.9(608)^{19}$ \\
\hline Hopanes $^{(6)}$ & 8.29 & $4.40(53)$ & $9.80(118)$ & $10.4(125)$ & $10.6(128)$ \\
\hline M-aro steranes & 16.1 & $750(47)$ & $169(105)$ & $17.3(107)$ & $173(107)$ \\
\hline T-aro steranes ${ }^{(6)}$ & 18.2 & $8.26(45)$ & $15.4(85)$ & $15.88(87)$ & $15.92(87)$ \\
\hline
\end{tabular}
(a): n-alkanes
(b): Total
(c): Total of phenanthrene and anthracene at $350^{\circ} \mathrm{C}$ extraction for SFE
(d): Total of methyl-phenanthrees and methyl-anthracenes at $350^{\circ} \mathrm{C}$ extraction for SFE
(e): Total of dimethyl-phenanthrees and dimethyl-anthracenes at $350^{\circ} \mathrm{C}$ extraction for SFE

Table 36. Accumulative recovery of hydrocarbons and biomarkers ( $\mathrm{ppm}$ ) from single Soxhlet extraction and triplicate HT-SFE, as well as \% relative recovery from HTSFE to recovery from Soxhlet extraction (in parenthesis) 
stronger interactions with OM and is 'trapped' in internal voids of polymeric structures of OM than the aliphatic and aromatic hydrocarbons. Therefore, based on the hypothesis of the impact of HT-SFE, which is the rearrangement of macromolecular of matrix under high temperature condition and the penetration of the supercritical fluid into the rearranged matrix (opened pore), it is reasonable that HT-SFE has more pronounced effect on the release of aliphatic and aromatic hydrocarbon than on that of the biomarkers. This observation is consistent with the results achieved in section 9.1 that only very small amount of biomarkers were recovered from SFE at high temperature. Therefore, HT-SFE has less impact on biomarkers than regular hydrocarbons due to different origins of those compounds. 


\section{CONCLUSION}

Stepwise HT-SFE has been used for the first time as a tool for speciation studies, and indeed, it has been proven to be a valuable technique. The thermal maturity inversion of the hopanes at elevated extraction temperature of HT-SFE proves the presence of the 'trapped' species in ancient sediment. The release of some low molecular weight compounds is suggested to be due to thermodesorption processes, whilst, that of higher molecular weight compounds is a combined effect of both solubility of analytes in supercritical $\mathrm{CO}_{2}$ and in some cases thermodersorption in HT-SFE, A better understanding of speciation of organic compounds in sediment by stepwise HT-SFE can greatly help organic geochemists to better understand the origin and fate of organic matter in the environment, and the formation of petroleum. 


\section{REFERENCES}

Akiba K. and Ohki J. (1988) Extraction of uranium by emulsion liquid membranes containing $\beta$-diketones and tributyl phosphate, High Temperature Materials and Processes, 8 21-28

Albaiges J.; Algaba J. and Grimalt J. (1984) Extractable and bound neutral lipids in some lacustrine sediments, Org. Geochem., 6 223-236

Ashraf-Khorassane M.; Memarian M. and Angaji M. (1992) Extraction of torbanites of various origins and evolutionary stages. Bacterial contribution to their formation. Cause of lack of botryococcane in bitumens, Fresenium J. Anal. Chem., 344, 492-496

Bartle K.D.; Jones D.W.; Pakdel H.; Snape C.E.; Calinili A.; Olcay A. and Tugrul T. (1979) Paraffinic hydrocarbons from SG extracts of coal as organic geochemical markers, Nature, 277, 284-287

Britz A.J. and Cloete F.L.D. (1990) The extraction of uranium from nitrate solutions using a resin containing tributyl phosphate, Hydrometallurgy, 25, 213-230

Edwards C.R.; Saskatoon and Saskatchewan (1992) Uranium extraction process alternatives, CIM Bulletin, 85 112-136

Enokida Y. and Suzuki A (1992) Estimation of uranium (VI) concentrations by temperature profile in solvent extraction processes using 30\% tri-n-butyl phosphate diluted with n-dodecane, J. Nuclear Sci. and Tech., 29, 461-471

Furton K.G. and Rein J. (1992) in: Supercritical Fluid technology, Relative effect of experimental variables, ACS Symposium Series 488, Bright F.V. and McNally M.E.P. (Eds), American chemical Society

Furton K.G. and Lin Q.(1993) variation in the supercritical fluid extraction of polychlorinated biphenyls as a function of sorbent type, extraction cell dimensions, and fluid flow rate, J. Chrom. Sci., 31, 201-206

Furton K.G.; Huang C.W.; Jaffé R. and Siere M.A. (1994) High-temperature supercritical fluid extraction of hydrocarbons from geological samples and comparison to Soxhlet extraction, J. High Res. Chrom., 17, 679-681.

Gong, Y.M. (1995) Experimental parameters controlling the supercritical fluid extraction of hydrocarbons from geological sample. Thesis submitted as a requirement for the 
degree of Master of Science in Chemistry, Chemistry Department, Florida International University, USA

Greibrokk T,; Radke M.; Skurdal M. and Willsch H. (1992) Multistage supercritical fluid extraction of petroleum source rocks: application to samples from Kimmeride Clay and Posidonia Shale formations, Org. Geochem.., 18, 447-455

Hawthorne S.B. (1990) Analytical-scale supercritical fluid extraction, Anal. Chem., 62, 633-642

Hawthorne S.B.; Miller D.J.; Burford M.D.; Langenfeld J.J.; Eckert-Tilotta S. and Louie P.K. (1993) Factors controlling quantitative supercritical fluid extraction of environmental samples, J.Chrom., 642, 301-317

Hopfgartner G.; Veuthey J.L.; Gülaçar F.O. and Buchs A. (1990) Extraction of biomarkers from sediments with supercritical carbon dioxide: A comparative study with the solvent extraction and thermodesorption methods, Org. Geochem., 15, 397-402

Huang J.W. (1995) Development and optimization of a high-temperature supercritical fluid extraction apparatus and comparison to soxhlet extraction. Thesis submitted as a requirement for the degree of Master of Science in Chemistry, Chemistry Department, Florida International University, USA

Jaffé R. and Gardinali P.R. (1990) Generation and maturation of carboxylic acids in ancient sediments from the Maracaibo Basin, Venezuela, Org. Geochem., 16, 211-218

Jaffé R.; Furton K.G.; Doraida Diaz; Neghie Hajje; Li Chen; and Christian Eckardt (1996) Results on the study of hydrocarbon speciation in ancient sediments by high temperature supercritical carbon dioxide extraction, Org. Geochem., In Press

Kawamura K.; Tannenbaum E.; Huizinga B.J. and Kaplan I.R. (1986) Long chain acids in pyrolyzates of Green River kerogen, Org. Geochem., 10, 1059-1065

Knipe C.R.; Gere D.R. and McNally M.E.P. (1992) in: Supercritical Fluid technology, Supercritical fluid extraction, ACS Symposium Series 488, Bright F.V. and McNally M.E.P. (Eds), American chemistry Society

Kramer R. and Levy M. (1989) Extraction of oil shales under supercritical conditions, Fuel, 68, 702-803

Kwapulinska G. and Janoszka B. (1990) spectrophotometric determination of uranium (VI) withchrome ázurol S and benzyldimethyllaurylamonium bromide, Fresenius J. Anal. chem.., 338, 641-642 
Laintz K.E. and Wai C.M. (1992) Extraction of metal ions from liquid and solid materials by supercritical carbon dioxide, Anal. Chem.., 64, 2875-2878

Lajat M.; Saliot A. and Schimmelmann A. (1990) Free and bound lipids in recent (18351987) sediments from the Santa Barbara Basin, Org. Geochem.,16, 793-803

Lin Y.; Brauer R.D.; Laintz K.E. and Wai C.M. (1993) Supercritical fluid extraction of lanthanides and actinides from solid materials with a fluorinated $\beta$-diketon, Anal. Chem., 65, 2549-2551

Mackenzie A.S. 1984 in: Advances in petroleum geochemistry, Brooks J. and Welte D. (Eds), Academic Press (Harcourt brace Jovanovich, Publishers)

McNally M.E.P. and bright F.V. (1992) in: Supercritical Fluid technology, Fundamental studies and applications of supercritical fluids, ACS Symposium Series 488, Bright F.V. and McNally M.E.P. (Eds), American chemical Society

Miles W.S. and Randall L.G. (1992) in: Supercritical Fluid technology, Supercritical fluid extraction in the analytical laboratory, ACS Symposium Series 488, Bright F.V. and McNally M.E.P. (Eds), American chemical Society

Monin J.C.; Barth D;; Perrut M.; Espitalié M. and Durand B. (1988) Extraction of hydrocarbons from sedimentary rocks by supercritical carbon dioxide, Org. Geochem.,13, 1079-1086

Peters K.E. and Moldowan J.M. (1993) The biomarker guide: Interpreting molecular fossils in petroleum and ancient sediments. Prentice Hall, New Jersey

Richnow H.H.; Jenisch A. and Michaelis, W. (1992) Structural investigations of sulphurrich macromolecular oil fractions and a kerogen by sequential chemical degradation, Adv.Org. Geochem.1991; Org. Geochem., 19, 351-370.

Rodehüser L.; Rubini P.R.; Bokolo K; Laakel N. and Delpuech J.-J. (1992) Liquid-liquid extraction of metal ions by neutral phosphor-amides. PART I. Extraction of uranyl ions from nitrate and sulphate media. Examination of extracted species by UV/Vis and ${ }^{31} \mathrm{P}$ NMR spectroscopy, Solvent extraction and ion exchange, 10, 559-577

Smith J.W.; George S.C. and Batts B.D. (1995) The geosynthesis of alkyl aromatics, Org. Geochem., 23, 71-80

Smith R.D. and Udseth H.R, (1983) New method for the direct analysis of supercritical fluid coal extraction and liquofraction, Fuel, 62, 466-468 
Tissot and Welte (1984) Petroleum formation and occurrence, Second Eddition, 583-857, Springger Veerlag, New York

Whitehead J.C. and Williams D.F.(1975) Solvent extraction of coal by supercritical gases, J. Inst. Fuel, 48, 182-184 
APPENDIX 


\begin{tabular}{|c|c|c|c|c|}
\hline & \multicolumn{2}{|c|}{ SFE OF POSDONLA SHLLLE AT $30^{\circ} \mathrm{C}$} & & \\
\hline & \multicolumn{3}{|c|}{$A$} & \\
\hline & \multicolumn{2}{|c|}{ Weight of sample $=2.9170 \%$} & & \\
\hline & \multicolumn{2}{|c|}{ Weight of IS (squalane) $1899 \mathrm{u}$} & & \\
\hline & \multicolumn{3}{|c|}{ Density of supercritical $\mathrm{CO}_{2}=0.904 \mathrm{~g} / \mathrm{ml}$} & \\
\hline & & & & \\
\hline & Comp & Plo Ares & IS Pk Arem & $(u g / g)$ \\
\hline \multirow[t]{26}{*}{ ALKANES } & $\mathrm{ClO}$ & 4283891 & 1844819 & 15.1 \\
\hline & $\mathrm{Cll}$ & 4623922 & 1844819 & 16.3 \\
\hline & $\mathrm{C} 12$ & 4189958 & 1844819 & 14.8 \\
\hline & $\mathrm{Cl}$ & 3823573 & 1844819 & 13.5 \\
\hline & C14 & 3675752 & 1844819 & 13.0 \\
\hline & C15 & 3533800 & 1844819 & 12.5 \\
\hline & $\mathrm{Cl}$ & 2978866 & 1844819 & 10.5 \\
\hline & $\mathrm{C} 17+\mathrm{PRI}$ & 9750872 & 1844819 & 34.4 \\
\hline & $\mathrm{Cl}$ & 2180062 & 1844819 & 7.69 \\
\hline & $\mathrm{PHY}$ & 3313807 & 1844819 & 11.7 \\
\hline & $\mathrm{C19}$ & 1875711 & 1844819 & 6.62 \\
\hline & $\mathrm{C} 20$ & 1744080 & 1844819 & 6.15 \\
\hline & $\mathrm{C21}$ & 1540413 & 1844819 & 5.44 \\
\hline & $\mathrm{C} 22$ & 1311501 & 1844819 & 463 \\
\hline & $\mathrm{C} 23$ & 1181093 & 1844819 & 4.17 \\
\hline & $\mathrm{C} 24$ & 1282066 & 1844819 & 452 \\
\hline & $\mathrm{C} 25$ & 1205947 & 1844819 & 4.26 \\
\hline & $\mathrm{C} 26$ & 972809 & 1844819 & 3.43 \\
\hline & $\mathrm{C} 27$ & 639826 & 1942985 & 2.14 \\
\hline & $\mathrm{C} 28$ & 575744 & 1942985 & 193 \\
\hline & $\mathrm{C} 29$ & 459422 & 1942985 & 1.54 \\
\hline & $\mathrm{C} 30$ & 475893 & 1942985 & 1.59 \\
\hline & C31 & 459637 & 1942985 & 1.54 \\
\hline & $\mathrm{C} 32$ & 338073 & 1942985 & 1.13 \\
\hline & $\mathrm{C} 33$ & 301338 & 1942985 & 1.01 \\
\hline & TOTAL ALKANES & & & 200 \\
\hline \multirow{19}{*}{ NAPHTHALENES } & NAPHTHALENE & 4224046 & 1957683 & 14.0 \\
\hline & $\mathrm{C}-1 \mathrm{MN}$ & 4940056 & 1957683 & 164 \\
\hline & $\mathrm{C}-2 \mathrm{MN}$ & 4155524 & 1957683 & 13.8 \\
\hline & TOTAL MN & & & 302 \\
\hline & 1.E2.EN & 953596 & 1957683 & 3.17 \\
\hline & 2,$6 ; 2,7 \mathrm{DMN}$ & 1478662 & 1957683 & 4.92 \\
\hline & 1,$3 ; 1,7 \mathrm{DMN}$ & 1962452 & 1957683 & 6.53 \\
\hline & $1,6 \mathrm{DMN}$ & 2292046 & 1957683 & 762 \\
\hline & 1,$4 ; 1,3 ; 1,5 \mathrm{DMN}$ & 1582572 & 1957683 & 5.26 \\
\hline & $1,8 \mathrm{DMN}$ & 578787 & 1957683 & 1.92 \\
\hline & TOTAL DMN & & & 29.4 \\
\hline & $1,3,7 \mathrm{MN}$ & 793775 & 1957683 & 2.64 \\
\hline & $1,3,6 \mathrm{mMN}$ & 1188973 & 1957683 & 3.95 \\
\hline & $1,4,6,1,3,5 \mathrm{MMN}$ & 732235 & 1957683 & 2.43 \\
\hline & $2,3,6 \mathrm{MMN}$ & 430579 & 1957683 & 1.43 \\
\hline & $1,2,7,1,6,7,1,2,6 \mathrm{TMN}$ & 1065976 & 1957683 & 3.54 \\
\hline & $1,2.5 \mathrm{MMN}$ & 483466 & 1957683 & 1.61 \\
\hline & TOTAL TMN & & & 15.6 \\
\hline & TOTAL NAPHS & & & 89.3 \\
\hline \multirow[t]{14}{*}{ PHENANTHRENES } & PHENANTHRENE & 710131 & 1980872 & 2.33 \\
\hline & ANTHRACENE & N/A & N/A & $\mathrm{N} / \mathrm{A}$ \\
\hline & 3-MP & 245370 & 1980872 & 0.806 \\
\hline & 2-MP & 340930 & 1980872 & 1.12 \\
\hline & 2.MA & $\mathrm{N} / \mathrm{A}$ & N/A & $\mathrm{N} / \mathrm{A}$ \\
\hline & $9 . \mathrm{MP}$ & 409369 & 1980872 & 1.35 \\
\hline & $1 \cdot \mathrm{MP}$ & 473891 & 1980872 & 1.56 \\
\hline & $1-M P+1-M A$ & $\mathrm{~N} / \mathrm{A}$ & $\mathrm{N} / \mathrm{A}$ & $\mathrm{N} / \mathrm{A}$ \\
\hline & $9 \mathrm{MA}$ & $\mathrm{N} / \mathrm{A}$ & $\mathrm{N} / \mathrm{A}$ & $\mathrm{N} / \mathrm{A}$ \\
\hline & TOTALMP & & & 483 \\
\hline & TOTAL MP+MA & $\mathrm{N} / \mathrm{A}$ & $\mathrm{N} / \mathrm{A}$ & $\mathrm{N} / \mathrm{A}$ \\
\hline & TOTAL DMP & 1104747 & 2191102 & 3.28 \\
\hline & TOTAL DMP+DMA & N/A & N/A & $\mathrm{N} / \mathrm{A}$ \\
\hline & TOTAL PHENAS & & & 10.4 \\
\hline
\end{tabular}




\begin{tabular}{|c|c|c|c|c|}
\hline & Come & Pk Ares & IS PK Arew & $(4 \mathrm{~g} / \mathrm{g})$ \\
\hline \multirow[t]{15}{*}{ HOPANES } & $\mathrm{C} 29 \alpha \beta$ & 1505278 & 19092828 & 0.513 \\
\hline & $C 29 \beta \alpha$ & 384068 & 19092828 & 0.131 \\
\hline & $\cos 30 \alpha$ & 2654074 & 19092828 & 0.905 \\
\hline & $\mathrm{C} 30 \beta \alpha$ & 579851 & 19092828 & 0.198 \\
\hline & $C 31 \alpha \beta(S)$ & 1017457 & 19092828 & 0.347 \\
\hline & $C 3 \mid \alpha \beta(R)$ & 738870 & 19092828 & 0.252 \\
\hline & $C 32 \alpha \beta(S)$ & 570661 & 19092828 & 0.195 \\
\hline & $C 32 \alpha \beta(R)$ & 539758 & 19092828 & 0.184 \\
\hline & $\mathrm{C} 33 \alpha \beta(\mathrm{S})$ & 922032 & 19092828 & 0.314 \\
\hline & $\mathrm{C} 33 \alpha \beta(\mathrm{R})$ & 872944 & 19092828 & 0.298 \\
\hline & $\mathrm{C} 34 \alpha p(S)$ & 636336 & 19092828 & 0.217 \\
\hline & C34 $\alpha \beta(R)$ & 560255 & 19092828 & 0.191 \\
\hline & $\mathrm{C} 35 \alpha \beta(\mathrm{S})$ & 461264 & 19092828 & 0.157 \\
\hline & $C 35 \alpha \beta(R)$ & 656423 & 19092828 & 0.224 \\
\hline & TOTAL & & & 4.13 \\
\hline \multirow[t]{8}{*}{ MONO AROMATICS } & $5 \beta(\mathrm{H}) \mathrm{C} 27(20 \mathrm{~S})$ & 1178705 & 17928903 & 0.428 \\
\hline & $5 \beta(\mathrm{HKC27}(20 \mathrm{R})$ & 1409133 & 17928903 & 0.512 \\
\hline & . & 4117681 & 17928903 & 1.50 \\
\hline & 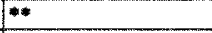 & 7691768 & 17928903 & 2.79 \\
\hline & $5 \alpha(\mathrm{H})(29(20 \mathrm{~s})$ & 2217305 & 16531754 & 0.873 \\
\hline & $+*$ & 3304025 & 16531754 & 1.30 \\
\hline & $504(\mathrm{HK} 29(20 \mathrm{R})$ & 1370081 & 17928903 & 0.497 \\
\hline & TOTAL & & & 7,90 \\
\hline \multirow[t]{9}{*}{ TRI AROMATICS } & $026(205)$ & 2639131 & 17912782 & 0.959 \\
\hline & $\mathrm{C} 26(20 \mathrm{R})+\mathrm{C} 27(20 \mathrm{~S})$ & 5697980 & 17912782 & 2.07 \\
\hline & $C 28(20 S)$ & 3505362 & 16533543 & 138 \\
\hline & $\mathrm{C} 27(20 \mathrm{R})$ & 2949211 & 16533543 & 116 \\
\hline & $C 28(20 R)$ & 4711166 & 17912782 & 1.71 \\
\hline & IOTAL & & & 7.28 \\
\hline & \multicolumn{2}{|c|}{$\because \quad 5 a(1) C 27(20 s)+5 \beta(H) C 28(20 S)$} & & \\
\hline & \multicolumn{3}{|c|}{ **: $50(\mathrm{H}) \mathrm{C} 27(20 \mathrm{R})+50(\mathrm{H}) 28(20 \mathrm{~S})+50(\mathrm{HXC} 28(20 \mathrm{R})+5 \mathrm{BC} 29(20 \mathrm{~S})$} & \\
\hline & \multicolumn{2}{|c|}{$\because 5 a(\mathrm{H}) 28(20 \mathrm{R})+5 B(\mathrm{H}) \mathrm{C} 29(20 \mathrm{R})$} & & \\
\hline
\end{tabular}




\begin{tabular}{|c|c|c|c|c|}
\hline & \multicolumn{3}{|c|}{ SFE OF POSTDONIA SHALE AT $150^{\circ} \mathrm{C}$} & \\
\hline & \multicolumn{3}{|c|}{$A$} & \\
\hline & \multicolumn{2}{|c|}{ Weight of samplem $2.9170 \mathrm{~g}$} & & \\
\hline & \multicolumn{2}{|c|}{ Weight of IS.(squalane) $=9.504$} & & \\
\hline & \multicolumn{3}{|c|}{ Density of supercritical $\mathrm{CO}_{2}=0.548 \mathrm{~g} / \mathrm{ml}$} & \\
\hline & & & & \\
\hline & Comp & Pk Area & IS Pk Ares & $(u g / g)$ \\
\hline \multirow[t]{26}{*}{ ALKANES } & $\mathrm{ClO}$ & 1149996 & 1891235 & 198 \\
\hline & $\mathrm{Cll}$ & 1149484 & 1891235 & 198 \\
\hline & $\mathrm{Cl2}$ & 1361626 & 1891235 & 234 \\
\hline & $\mathrm{Cl3}$ & 1296803 & 1891235 & 2.23 \\
\hline & $\mathrm{C} 14$ & 1558053 & 1891235 & 268 \\
\hline & $\mathrm{C} 15$ & 1628773 & 1891235 & 2.80 \\
\hline & C16 & 1510781 & 1891235 & 2.60 \\
\hline & CI7+PRI & 5942556 & 1891235 & 10.2 \\
\hline & $\mathrm{C18}$ & 1256515 & 1891235 & 2.16 \\
\hline & $P H Y$ & 2373445 & 1891235 & 4.09 \\
\hline & $\mathrm{C19}$ & 1256798 & 1891235 & 2.16 \\
\hline & $\mathrm{C} 20$ & 1066072 & 1891235 & 1.84 \\
\hline & C21 & 934666 & 1891235 & 1.61 \\
\hline & $C 22$ & 824212 & 1891235 & 1.42 \\
\hline & $\mathrm{C} 23$ & 846046 & 1891235 & 1.46 \\
\hline & $\mathrm{C} 24$ & 907867 & 1891235 & 1.56 \\
\hline & $\mathrm{C} 25$ & 1070210 & 1891235 & 1.84 \\
\hline & $\mathrm{C} 26$ & 915646 & 1891235 & 1.58 \\
\hline & $\mathrm{C} 27$ & 701537 & 2018419 & 1.13 \\
\hline & $\mathrm{C} 28$ & 538463 & 2018419 & 0.869 \\
\hline & $\mathrm{C29}$ & 416292 & 2018419 & 0.672 \\
\hline & $\mathrm{C} 30$ & 474438 & 2018419 & 0.766 \\
\hline & C31 & 584451 & 2018419 & 0.943 \\
\hline & $\mathrm{C} 32$ & 434846 & 2018419 & 0.702 \\
\hline & $\mathrm{C} 33$ & 370690 & 2018419 & 0.598 \\
\hline & TOTAL ALKANES & & & 52.3 \\
\hline \multirow[t]{19}{*}{ NAPHTHALENES } & NAPHTHALENE & 1635352 & 1991456 & 2.67 \\
\hline & $\mathrm{C}-1 \mathrm{MN}$ & 2435230 & 1991456 & 398 \\
\hline & $\mathrm{C} .2 \mathrm{MN}$ & 3102477 & 1991456 & 5.07 \\
\hline & TOTAL MN & & & 9.06 \\
\hline & $1+\mathrm{E}, 2-\mathrm{EN}$ & 670295 & 1991456 & 1.10 \\
\hline & $2,6.2 .7 \mathrm{DMN}$ & 878814 & 1991456 & 1.44 \\
\hline & $1,3,1,7 \mathrm{DMN}$ & 1516841 & 1991456 & 2.48 \\
\hline & $1,6 \mathrm{DMN}$ & 1784153 & 1991456 & 2.92 \\
\hline & $1,4,1,3,1,5 \mathrm{DMN}$ & 1021265 & 1991456 & 1.67 \\
\hline & $1,8 \mathrm{DMN}$ & 552495 & 1991456 & 0.904 \\
\hline & TOTAL DMN & & & 105 \\
\hline & $1,3,7 \mathrm{MMN}$ & 727756 & 1991456 & 1.19 \\
\hline & $1,3,6 \mathrm{NMN}$ & 1117281 & 1991456 & 1.83 \\
\hline & $1,4,6,1,3,5 \mathrm{MN}$ & 783355 & 1991456 & 1.28 \\
\hline & $2,3,6 \mathrm{TMN}$ & 367170 & 1991456 & 0,600 \\
\hline & $(1,2,7,1,6,7,1,2,6 \mathrm{TMN}$ & 986992 & 1991456 & 1.61 \\
\hline & $1,2,5 \mathrm{TMN}$ & 567435 & 1991456 & 0.928 \\
\hline & TOTAL TMN & & & 7.44 \\
\hline & TOTAL NAPHS & & & 29.7 \\
\hline \multirow[t]{14}{*}{ PHENANTHIRENES } & PHENANTHRENE & 635335 & 1991456 & 1.04 \\
\hline & ANTHRACENE & N/A & $\mathrm{N} / \mathrm{A}$ & $\mathrm{N} / \mathrm{A}$ \\
\hline & 3-MP & 276987 & 1991456 & 0.453 \\
\hline & 2-MP & 324860 & 1991456 & 0.531 \\
\hline & $2-\mathrm{MA}$ & N/A & $\mathrm{N} / \mathrm{A}$ & N/A \\
\hline & 9-MP & 406568 & 1991456 & 0.665 \\
\hline & $1-M P$ & 455178 & 1991456 & 0.744 \\
\hline & $1-M P+1-M A$ & $\mathrm{~N} / \mathrm{A}$ & $N / A$ & $\mathrm{~N} / \mathrm{A}$ \\
\hline & $9 \mathrm{MA}$ & $\mathrm{N} / \mathrm{A}$ & $\mathrm{N} / \mathrm{A}$ & $N / A$ \\
\hline & TOTAL MP & & & 2.39 \\
\hline & TOTAL MP+MA & $\mathrm{N} / \mathrm{A}$ & $\mathrm{N} / \mathrm{A}$ & $\mathrm{N} / \mathrm{A}$ \\
\hline & TOTAL DMP & 1367045 & 2244457 & 198 \\
\hline & TOTAL DMP+DMA & NA & N/A & $\mathrm{N} / \mathrm{A}$ \\
\hline & TOTAL PHENAS & & & 5.42 \\
\hline
\end{tabular}




\begin{tabular}{|c|c|c|c|c|}
\hline & Comp & Pk Are & IS PK Area & $(\mathrm{ug} / \mathrm{g})$ \\
\hline \multirow{15}{*}{ HOPANES } & $C 29 \alpha \beta$ & 3413264 & 17621152 & 0.631 \\
\hline & $C 29 \beta \alpha$ & 947073 & 17621152 & 0.175 \\
\hline & $c 30 \alpha \beta$ & $564089 ?$ & 17621152 & 1.04 \\
\hline & $1 \mathrm{c} 30 \beta \alpha$ & 1514693 & 17621152 & 0.280 \\
\hline & $\mathrm{C} 31 \alpha \beta(\mathrm{S})$ & 2146581 & 17621152 & 0.397 \\
\hline & $C 31 \alpha \beta(R)$ & 1563474 & 17621152 & 0.289 \\
\hline & $\mathrm{C} 32 \alpha \rho(\mathrm{S})$ & 1193539 & 17621152 & 0.221 \\
\hline & $\mathrm{C} 32 \alpha \beta(\mathrm{R})$ & 1091130 & 17621152 & 0.202 \\
\hline & $C 33 \alpha \beta(S)$ & 1808808 & 17621152 & 0.334 \\
\hline & $\mathrm{C} 33 \alpha \beta(\mathrm{R})$ & 1663944 & 17621152 & 0.308 \\
\hline & $C 34 \alpha \beta(S)$ & 1090089 & 17621152 & 0.201 \\
\hline & $C 34 \alpha \beta(R)$ & 1020645 & 17621152 & 0.189 \\
\hline & $c 35 \alpha \beta(s)$ & 881146 & 17621152 & 0.163 \\
\hline & $C 35 \alpha \beta(R)$ & 1110555 & 17621152 & 0.205 \\
\hline & TOTAL & & & 464 \\
\hline \multirow[t]{8}{*}{ MONO AROMATICS } & $5 \beta(\mathrm{H}) 27(20 \mathrm{~S})$ & 2071651 & 16304585 & 0414 \\
\hline & $5 \beta(\mathrm{H}) \mathrm{C} 27(20 \mathrm{R})$ & 2441839 & 16304585 & 0488 \\
\hline & 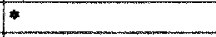 & 7977374 & 16304585 & 159 \\
\hline & $*$ & 13954622 & 13294352 & 3.42 \\
\hline & $504 \mathrm{H})(2920 \mathrm{~S})$ & 4633555 & 13294352 & 1.14 \\
\hline & $\$ * *$ & 6076383 & 13294352 & 1.49 \\
\hline & $5 \alpha(\mathrm{H}) \mathrm{C} 29(20 \mathrm{R})$ & 2221513 & 13294352 & 0.544 \\
\hline & TOTAL & & & 9.08 \\
\hline \multirow[t]{10}{*}{ TRI AROMATICS } & $\mathrm{C} 26(20 \mathrm{~S})$ & 3848588 & 13294352 & 0.943 \\
\hline & $\mathrm{C} 26(20 \mathrm{R})+\mathrm{C} 27(20 \mathrm{~S})$ & 7528625 & 13294352 & 1.84 \\
\hline & C28(20s) & 4673130 & 13294352 & 1.14 \\
\hline & $\mathrm{C} 27(20 \mathrm{R})$ & 3983417 & 13294352 & 0.976 \\
\hline & $C 28(20 R)$ & 4511652 & 13294352 & 1.11 \\
\hline & TOTAL & & & 6.01 \\
\hline & & & & \\
\hline & \multicolumn{2}{|c|}{$: \quad \operatorname{san}(\mathrm{H}) 27(20 \mathrm{~S})+5 \mathrm{~B}(\mathrm{H}) 28(20 \mathrm{~S})$} & & \\
\hline & \multicolumn{3}{|c|}{ **: $5 \alpha \mathrm{H}) \mathrm{C} 27(20 \mathrm{R})+5 \alpha(\mathrm{H}) \mathrm{C} 28(20 \mathrm{~S})+5 \beta(\mathrm{H}) \mathrm{C} 28(20 \mathrm{R})+5 \beta \mathrm{C} 29(20 \mathrm{~S})$} & \\
\hline & $0 *+500(\mathrm{G}) 28(20 \mathrm{R})$ & $9(20 R)$ & & \\
\hline
\end{tabular}




\begin{tabular}{|c|c|c|c|c|}
\hline & \multirow{2}{*}{\multicolumn{3}{|c|}{ SFE OF POSTDONLA SHLALE AT $250^{\circ} \mathrm{C}$}} & \\
\hline & & & & \\
\hline & \multicolumn{3}{|c|}{ Werght of sarrple $=2.9170 \mathrm{~g}$} & \\
\hline & \multicolumn{3}{|c|}{ Weight of IS (squalane) $=9.50 \mathrm{ug}$} & \\
\hline & \multicolumn{3}{|c|}{ Density of supercritical $\mathrm{CO}_{2}=0.366 \mathrm{~g} / \mathrm{ml}$} & \\
\hline & & & & \\
\hline & Comp & Pl Area & IS Pk Arem & $(\mathrm{ug} / \mathrm{g})$ \\
\hline \multirow[t]{26}{*}{ ALKANES } & $\mathrm{Cl0}$ & 617669 & 3118361 & 0.645 \\
\hline & Cll & 633621 & 2958193 & 0.698 \\
\hline & $\mathrm{Cl2}$ & 627204 & 2958193 & 0.691 \\
\hline & $\mathrm{Cl3}$ & 736245 & 2997951 & 0.800 \\
\hline & $\mathrm{Cl} 4$ & 651157 & 1891235 & 1.12 \\
\hline & $\mathrm{Cl} 5$ & 639108 & 2997951 & 0694 \\
\hline & $\mathrm{Cl} 6$ & 588064 & 2997951 & 0.639 \\
\hline & $C 17+P R 1$ & 1942637 & 2997951 & 2.11 \\
\hline & $\mathrm{C} 18$ & 525008 & 2958193 & 0.578 \\
\hline & $\mathrm{PHY}$ & 871341 & 2958193 & 0.959 \\
\hline & $\mathrm{Cl}$ & 581530 & 2958193 & 0.640 \\
\hline & $\mathrm{C} 20$ & 407417 & 2958193 & 0.449 \\
\hline & $\mathrm{C21}$ & 451597 & 2958193 & 0.508 \\
\hline & $\mathrm{C} 22$ & 426517 & 2958193 & 0.470 \\
\hline & $\mathrm{C} 23$ & 453427 & 2958193 & 0.499 \\
\hline & $\mathrm{C} 24$ & 519280 & 2958193 & 0.572 \\
\hline & $\mathrm{C} 25$ & 567284 & 3118361 & 0.592 \\
\hline & $\mathrm{C} 26$ & 563034 & 2958193 & 0.620 \\
\hline & $\mathrm{C} 27$ & 387012 & 3118361 & 0.404 \\
\hline & $\mathrm{C} 28$ & 306989 & 3118361 & 0.321 \\
\hline & $\mathrm{C} 29$ & 262861 & 3118361 & 0.275 \\
\hline & $\mathrm{C} 30$ & 225887 & 3118361 & 0.236 \\
\hline & C31 & 252785 & 3118361 & 0.264 \\
\hline & $\mathrm{C} 32$ & 241186 & 3118361 & 0.252 \\
\hline & $\mathrm{C} 33$ & 173545 & 3118361 & 0.181 \\
\hline & TOTAL ALKANES & & & 15.2 \\
\hline \multirow[t]{19}{*}{ NAPHTHALENES } & NAPHTHALENE & 4198832 & 3031734 & 451 \\
\hline & $\mathrm{C}-1 \mathrm{MN}$ & 6397547 & 3031734 & 687 \\
\hline & $\mathrm{C}-2 \mathrm{MN}$ & 5443648 & 3031734 & 5.85 \\
\hline & TOTAL MN & & & 12.7 \\
\hline & 1-E, 2-EN & 1520106 & 3031734 & 1.63 \\
\hline & $2,6,2,7 \mathrm{DMN}$ & 3025655 & 3031734 & 325 \\
\hline & $1,3,1,7 \mathrm{DMN}$ & 3673801 & 3031734 & 3.95 \\
\hline & $1,6 \mathrm{DMN}$ & 3704639 & 3031734 & 3.98 \\
\hline & $1,4,1,3,1,5 \mathrm{DMN}$ & 2366867 & 3031734 & 2.54 \\
\hline & $1,8 \mathrm{DMN}$ & 842260 & 3031734 & 0905 \\
\hline & TOTAL DMN & 842260 & & 16.3 \\
\hline & $1,3, \mathrm{TMMN}$ & 1568953 & 3031734 & 1.69 \\
\hline & $1,3,6 \mathrm{TMN}$ & 1907526 & 3031734 & 2.05 \\
\hline & $1,4,6,1,3,5 \mathrm{TMN}$ & 1327454 & 3031734 & 1.43 \\
\hline & $2,3,6 \mathrm{TMN}$ & 930143 & 3031734 & 1.00 \\
\hline & $1,2,7 ; 1,6,7,1,2,6 \mathrm{TMN}$ & 2210473 & 3031734 & 237 \\
\hline & $1,2,5 \mathrm{TMN}$ & 784096 & 3031734 & 0.842 \\
\hline & TOTAL TMN & & & 9.38 \\
\hline & TOTAL NAPHS & & & 42.9 \\
\hline \multirow[t]{14}{*}{ PHENATIRENES } & PHENATMRENE & 1759473 & 3099096 & 1.85 \\
\hline & ANTHRACENE & $\mathrm{N} / \mathrm{A}$ & $\mathrm{N} / \mathrm{A}$ & $N / A$ \\
\hline & 3-MP & 583001 & 3099096 & 0.613 \\
\hline & 2-MP & 726144 & 3099096 & 0.763 \\
\hline & $2 \mathrm{MA}$ & $\mathrm{N} / \mathrm{A}$ & $\mathrm{N} / \mathrm{A}$ & $\mathrm{N} / \mathrm{A}$ \\
\hline & 9-MP & 774567 & 3099096 & 0.814 \\
\hline & $1-\mathrm{MP}$ & 153338 & 3099096 & 1.61 \\
\hline & $1-M P+1+M A$ & $\mathrm{~N} / \mathrm{A}$ & $\mathrm{N} / \mathrm{A}$ & $\mathrm{N} / \mathrm{A}$ \\
\hline & $9 \mathrm{MA}$ & N/A & $\mathrm{N} / \mathrm{A}$ & $\mathrm{N} / \mathrm{A}$ \\
\hline & TOTAL MP & & & 3.80 \\
\hline & TOTAL MP+MA & $\mathrm{N} / \mathrm{A}$ & $N / A$ & $\mathrm{~N} / \mathrm{A}$ \\
\hline & TOTAL DMP & 2370911 & 3099096 & 2.49 \\
\hline & TOTAL DMP+DMA & $N / A$ & N/A & N/A \\
\hline & TOTAL PHENAS & & & 8.14 \\
\hline
\end{tabular}




\begin{tabular}{|c|c|c|c|c|}
\hline & Comp & Pk Aren & IS Pk Ares & $(\mathrm{ug} / \mathrm{g})$ \\
\hline \multirow[t]{15}{*}{ HOPANES } & $C 29 \alpha \beta$ & 758678 & 9577063 & 0258 \\
\hline & $C 29 \beta \alpha$ & 110538 & 10487286 & 0034 \\
\hline & $C 30 \alpha \beta$ & $5 \longdiv { 5 4 2 7 }$ & 9577063 & 0.175 \\
\hline & $\cos \beta \alpha$ & 94040 & 10487286 & 0.029 \\
\hline & C3la $\beta(S)$ & 336435 & 10720959 & 0072 \\
\hline & $\mathrm{C} 31 \alpha \beta(\mathrm{R})$ & 173118 & 10720959 & 0.053 \\
\hline & $c 32 \alpha \beta(s)$ & 116180 & 10487286 & 0.036 \\
\hline & $\mathrm{C} 32 \alpha \beta(\mathrm{R})$ & 126843 & 10487286 & 0.039 \\
\hline & C33ap(S) & 146197 & 10487286 & 0.045 \\
\hline & $\mathrm{C} 33 \alpha \beta(\mathrm{R})$ & 170902 & 10487286 & 0.053 \\
\hline & C34aßs $(S)$ & 79465 & 10720959 & 0.024 \\
\hline & $C 34 \alpha \beta(R)$ & 99046 & 10720959 & 0.030 \\
\hline & $C 35 \alpha \beta(S)$ & 71510 & 10720959 & 0.022 \\
\hline & $C 35 \alpha \beta(R)$ & 80576 & 10720959 & 0.024 \\
\hline & TOTAL & & & 0.896 \\
\hline \multirow[t]{8}{*}{ MONO AROMATICS } & $58(\mathrm{H}) 27(20 \mathrm{~S})$ & 91088 & 10487286 & 0.028 \\
\hline & $5 \mathrm{~B}(\mathrm{H}) \mathrm{C} 27(20 \mathrm{R})$ & 124923 & 10194547 & 0.040 \\
\hline & क & 379797 & 10194547 & 0.121 \\
\hline & $*$ & 633153 & 9577063 & 0.215 \\
\hline & $504 \mathrm{HX29} 20 \mathrm{~S})$ & 210870 & 10464261 & 0.066 \\
\hline & $1 \%$ & 274414 & 10464261 & 0.085 \\
\hline & $50(\mathrm{H}) \mathrm{C} 29(20 \mathrm{R})$ & 108026 & 10487286 & 0.034 \\
\hline & TOTAL & & & 0.589 \\
\hline \multirow[t]{9}{*}{ TRI AROMATICS } & $\mathrm{C} 26(20 \mathrm{~S})$ & 276929 & 9577063 & 0.094 \\
\hline & $(\mathrm{C} 26(20 \mathrm{R})+\mathrm{C} 27(20 \mathrm{~S})$ & 538440 & 9577063 & 0.183 \\
\hline & $\mathrm{C} 28(20 \mathrm{~S})$ & 284286 & 9577063 & 0.097 \\
\hline & $\mathrm{C} 27(20 \mathrm{R})$ & 270341 & 9577063 & 0.092 \\
\hline & $\mathrm{C} 28(20 \mathrm{R})$ & 306555 & 9577063 & 0.104 \\
\hline & TOTAL & & & 0.570 \\
\hline & \multicolumn{2}{|c|}{ - $\quad 50(1) C 27(20 S)+58(H) C 28(20 S)$} & & \\
\hline & \multicolumn{3}{|c|}{ **: $5 \alpha(\mathrm{HCC} 27(20 \mathrm{R})+5 \alpha(\mathrm{H}) \mathrm{C} 28(20 \mathrm{~S})+50(\mathrm{H}) 28(20 \mathrm{R})+5 \mathrm{BC} 29(20 \mathrm{~S})$} & \\
\hline & $* * 50(\mathrm{HC} 28(20 \mathrm{R})+$ & (20R) & & \\
\hline
\end{tabular}




\begin{tabular}{|c|c|c|c|c|}
\hline & \multicolumn{3}{|c|}{ SFE OF POSIDONLA SHALE AT $350^{\circ} \mathrm{C}$} & \\
\hline & \multicolumn{3}{|c|}{$A$} & \\
\hline & \multicolumn{2}{|c|}{ Weight of sample $=2.9170 \mathrm{~g}$} & & \\
\hline & \multirow{2}{*}{\multicolumn{2}{|c|}{$\begin{array}{l}\text { Weight of LS (squalane) }=18.99 \text { un } \\
\text { Density of supercritical } \mathrm{CO}_{2}=0.2\end{array}$}} & & \\
\hline & & & Density of supercritical $\mathrm{CO}_{2}=0.281 \mathrm{~g} / \mathrm{m}$ & \\
\hline & & & & \\
\hline & Comp & PkArea & IS Pk Area & (ug/g) \\
\hline \multirow[t]{25}{*}{ ALKANES } & $\mathrm{C} 10$ & 241833 & 2592683 & 0.607 \\
\hline & $\mathrm{Cll}$ & 534635 & 2583694 & 1.35 \\
\hline & $\mathrm{Cl2}$ & 519004 & 2583694 & 1.31 \\
\hline & $\mathrm{Cl3}$ & 658351 & 2583694 & 166 \\
\hline & $\mathrm{Cl4}$ & 536985 & 2583694 & 1.35 \\
\hline & $\mathrm{Cl}$ & 502636 & 2583694 & 127 \\
\hline & $\mathrm{C} 16$ & 348962 & 2583694 & 0879 \\
\hline & $\mathrm{C} 17$ & 397814 & 2583694 & 100 \\
\hline & $\mathrm{C} 18$ & 283745 & 2592683 & 0.712 \\
\hline & $\mathrm{Cl}$ & 248348 & 2583694 & 0.626 \\
\hline & $\mathrm{C} 20$ & 351153 & 258369 & 0.885 \\
\hline & C21 & 281372 & 2592683 & 0707 \\
\hline & $\mathrm{C} 22$ & 295820 & 2592683 & 0.743 \\
\hline & $\mathrm{C} 23$ & 237290 & 2592683 & 0.596 \\
\hline & $\mathrm{C} 24$ & 218261 & 2592683 & 0.548 \\
\hline & $\mathrm{C} 25$ & 190351 & 2592683 & 0.478 \\
\hline & $\mathrm{C} 26$ & 232321 & 2721253 & 0.556 \\
\hline & $\mathrm{C} 27$ & 189423 & 2721253 & 0.453 \\
\hline & $\mathrm{C} 28$ & 143615 & 2721253 & 0.344 \\
\hline & $\mathrm{C} 29$ & 136612 & 2721253 & 0.327 \\
\hline & $\mathrm{C} 30$ & 136560 & 2721253 & 0.327 \\
\hline & C31 & 70693 & 2721253 & 0.169 \\
\hline & $\mathrm{c} 32$ & 68924 & 2721253 & 0.165 \\
\hline & C33 & N.D. & & 0.000 \\
\hline & TOTAL ALKANES & & & 17.1 \\
\hline \multirow[t]{19}{*}{ NAPHTHALENES } & NAPHTHALENE & 3692112 & 2705006 & 8.89 \\
\hline & $\mathrm{C}-1 \mathrm{MN}$ & 6179746 & 2705006 & 14.9 \\
\hline & $\mathrm{C}-2 \mathrm{MN}$ & 3447790 & 2705006 & 8.30 \\
\hline & TOTAL MN & & & 23.2 \\
\hline & $1-\mathrm{E}_{2} 2-\mathrm{EN}$ & 1349039 & 2705006 & 3.25 \\
\hline & 2,$6 ; 2,7 \mathrm{DMN}$ & 3908736 & 2705006 & 9.41 \\
\hline & 1,$3 ; 1,7 \mathrm{DMN}$ & 4253575 & 2705006 & 10.2 \\
\hline & $1,6 \mathrm{DMN}$ & 2587705 & 2705006 & 6.23 \\
\hline & $1,4,1,3,1,5 \mathrm{DMN}$ & 2382883 & 2705006 & 5.73 \\
\hline & $1,8 \mathrm{DMN}$ & 1115248 & 2705006 & 2.68 \\
\hline & TOTAL DMN & & & 37.5 \\
\hline & $1,3,7 \mathrm{TMN}$ & 2792404 & 2705006 & 6.72 \\
\hline & $1,3,6 \mathrm{TMN}$ & 2580611 & 2705006 & 6.21 \\
\hline & $1,4,6 ; 1,3,5 \mathrm{TMN}$ & 1921517 & 2705006 & 4.62 \\
\hline & $2,3,6 \mathrm{TMN}$ & 2154413 & 2705006 & 5.19 \\
\hline & $1,2,7,1,6,7,1,2,6 \mathrm{TMO}$ & 3506992 & 2705006 & 8.44 \\
\hline & $1,2,5 \mathrm{TMN}$ & 719182 & 2705006 & 1.73 \\
\hline & TOTAL TMN & & & 329 \\
\hline & TOTAL NAPHS & & & 103 \\
\hline \multirow[t]{14}{*}{ PHENANTHRENES } & PHENANTHRENE & 1589813 & 2592683 & 399 \\
\hline & ANTHRACENE & 922424 & 2592683 & 2.32 \\
\hline & $3-\mathrm{MP}$ & 912426 & 2592683 & 2.29 \\
\hline & 2-MP & 1031254 & 2592683 & 2.59 \\
\hline & 2-MA & 1279351 & 2592683 & 3.21 \\
\hline & $9-\mathrm{MP}^{3}$ & 862508 & 2592683 & 2.17 \\
\hline & $1 \cdot \mathrm{MP}$ & $N / A$ & $N / A$ & $\mathrm{~N} / \mathrm{A}$ \\
\hline & $1 \cdot \mathrm{MP}+1 \cdot \mathrm{MA}$ & 1430506 & 2592683 & 3.59 \\
\hline & $9 \mathrm{MA}$ & 381664 & 2592683 & 0958 \\
\hline & TOTAL MP & $N / A$ & $N / A$ & $N / A$ \\
\hline & TOTAL MP+MA & & & 14.8 \\
\hline & TOTAL DMP & $N / A$ & $N / A$ & $\mathrm{~N} / \mathrm{A}$ \\
\hline & TOTAL DMP+DMA & 6470314 & 2592683 & 16.2 \\
\hline & TOTAL PHENAS & & & 37.36 \\
\hline
\end{tabular}




\begin{tabular}{|c|c|c|c|c|}
\hline & Comp & PKAre & IS Pk Are & $($ ug/g) \\
\hline \multirow{15}{*}{ HOPANES } & $C 29 \alpha \beta$ & 423231 & 18799275 & 0.147 \\
\hline & $\mathrm{C} 29 \beta \alpha$ & 119218 & 18799275 & 0.041 \\
\hline & $C 30 \alpha \beta$ & 121481 & 18799275 & 0042 \\
\hline & C30ßa & 75507 & 18799275 & 0.026 \\
\hline & $C 3 \mid \alpha \beta(S)$ & 36655 & 18799275 & 0.013 \\
\hline & $C 3 \mid \alpha \beta(R)$ & 76114 & 18799275 & 0026 \\
\hline & $C 32 \alpha \beta(S)$ & 11531 & 18799275 & 0.004 \\
\hline & $C 32 \alpha \beta(R)$ & 52154 & 18799275 & 0.018 \\
\hline & C33 $\alpha \beta(S)$ & N/A & $\mathrm{N} / \mathrm{A}$ & $\mathrm{N} / \mathrm{A}$ \\
\hline & $C 33 \alpha \beta(R)$ & N/A & $\mathrm{N} / \mathrm{A}$ & N/A \\
\hline & $C 34 \alpha \beta(S)$ & N/A & $\mathrm{N} / \mathrm{A}$ & $\mathrm{N} / \mathrm{A}$ \\
\hline & $C 34 \alpha \beta(R)$ & $\mathrm{N} / \mathrm{A}$ & N/A & $\mathrm{N} / \mathrm{A}$ \\
\hline & C35 $\alpha \beta(S)$ & $\mathrm{N} / \mathrm{A}$ & N/A & N/A \\
\hline & $C 35 \alpha \beta(R)$ & $\mathrm{N} / \mathrm{A}$ & N/A & N/A \\
\hline & TOTAL & & & 0.317 \\
\hline & & & & \\
\hline \multirow{9}{*}{ MONO AROMATICS } & $5 \beta(\mathrm{H}) \mathrm{C} 27(20 \mathrm{~S})$ & N/A & $\mathrm{N} / \mathrm{A}$ & N/A \\
\hline & $5 \beta(H \times 27(20 R)$ & $\mathrm{N} / \mathrm{A}$ & N/A & N/A \\
\hline & $*$ & NA & N/A & N/A \\
\hline & $* *$ & NA & $\mathrm{N} / \mathrm{A}$ & $\mathrm{N} / \mathrm{A}$ \\
\hline & $5 \alpha(H) C 29(20 S)$ & N/A & $\mathrm{N} / \mathrm{A}$ & N/A \\
\hline & $+* *$ & N/A & N/A & $\mathrm{N} / \mathrm{A}$ \\
\hline & $504(\mathrm{H}) 2920 \mathrm{R})$ & N/A & $\mathrm{N} / \mathrm{A}$ & N/A \\
\hline & ToraL & & & $\mathrm{N} / \mathrm{A}$ \\
\hline & & & & \\
\hline \multirow[t]{10}{*}{ TRI AROMATICS } & $\mathrm{C} 26(20 \mathrm{~S})$ & 24520 & 18799275 & 0.008 \\
\hline & $C 26(20 R)+C 27(20 S)$ & 44652 & 18799275 & 0.015 \\
\hline & C28(20S) & 20149 & 18799275 & 0.007 \\
\hline & $\mathrm{C} 27(20 \mathrm{R})$ & 23758 & 18799275 & 0.008 \\
\hline & $\mathrm{C} 28(20 \mathrm{R})$ & 30678 & 18799275 & 0.011 \\
\hline & TOTAL & & & 0.050 \\
\hline & & & & \\
\hline & \multicolumn{2}{|c|}{$=\quad 5 \alpha(H) C 27(20 S)+5 \beta(H) C 28(20 S)$} & & \\
\hline & \multicolumn{3}{|c|}{$* 5 \alpha(H) C 27(20 \mathrm{R})+5 \alpha(H) C 28(20 S)+5 \beta(H) C 28(20 \mathrm{R})+5 \beta C 29(20 \mathrm{~S})$} & \\
\hline & $* * * 5 a(H) C 28(20 R)+5$ & $9(20 \mathrm{R})$ & & \\
\hline
\end{tabular}




\begin{tabular}{|c|c|c|c|c|}
\hline & \multicolumn{3}{|c|}{ SFE OF POSTDONLA SHALE AT $50^{\circ} \mathrm{C}$} & \\
\hline & \multicolumn{3}{|c|}{ B } & \\
\hline & \multicolumn{3}{|c|}{ Weight of sample $=3.00138$} & \\
\hline & \multicolumn{3}{|c|}{ Weight of IS (squalane) $=18.99 \mathrm{ug}$} & \\
\hline & \multicolumn{3}{|c|}{ Density of supercritical $\mathrm{CO}_{2}=0.904 \mathrm{~g} / \mathrm{m}$} & \\
\hline & & & & \\
\hline & Comp & Pk Ane & IS Pk Are & (ug/g) \\
\hline \multirow[t]{26}{*}{ ALKANES } & $\mathrm{Clo}$ & 6645735 & 3137149 & 134 \\
\hline & $\mathrm{CH}$ & 7298764 & 3137149 & 147 \\
\hline & $\mathrm{Cl2}$ & 4832393 & 3137149 & 9.75 \\
\hline & $\mathrm{Cl3}$ & 6049371 & 3137149 & 12.2 \\
\hline & $\mathrm{Cl} 4$ & 6383777 & 3137149 & 12.9 \\
\hline & $\mathrm{Cl5}$ & 6479585 & 3137149 & 13.1 \\
\hline & $\mathrm{Cl6}$ & 6143604 & 3137149 & 12.4 \\
\hline & $\mathrm{C} I 7+\mathrm{PRI}$ & 18968448 & 3137149 & 38.3 \\
\hline & $\mathrm{Cl} 8$ & 4563772 & 3137149 & 9.20 \\
\hline & PHY & 6340940 & 3137149 & 12.8 \\
\hline & $\mathrm{C19}$ & 3731484 & 3137149 & 7.53 \\
\hline & $\mathrm{C}_{20}$ & 3192676 & 3137149 & 6.44 \\
\hline & $\mathrm{C} 21$ & 2723071 & 3137149 & 5.49 \\
\hline & $\mathrm{C} 22$ & 2132458 & 3137149 & 4.30 \\
\hline & $\mathrm{C} 23$ & 2162638 & 3137149 & 4.36 \\
\hline & $\mathrm{C} 24$ & 2001981 & 3137149 & 4.04 \\
\hline & $\mathrm{C25}$ & 1710910 & 3137149 & 3.45 \\
\hline & $\mathrm{C} 26$ & 1631891 & 3137149 & 3.29 \\
\hline & $\mathrm{C27}$ & 932582 & 3137149 & 1.88 \\
\hline & $\mathrm{C} 28$ & 673334 & 3137149 & 1.88 \\
\hline & $\mathrm{C} 29$ & 626963 & 3137149 & 1.36 \\
\hline & $\mathrm{C} 30$ & 621649 & 3252616 & 122 \\
\hline & C31 & 686879 & 3252616 & 134 \\
\hline & $\mathrm{C} 32$ & 503052 & 3252616 & 0.979 \\
\hline & $\mathrm{C} 33$ & 486786 & 3252616 & 0.947 \\
\hline & TOTAL ALKANES & & & 197 \\
\hline \multirow[t]{19}{*}{ NAPHTHALENES } & NAPHTHALENE & 8901098 & 4365790 & 12.9 \\
\hline & $\mathrm{C}-1 \mathrm{MN}$ & 9998820 & 4365790 & 145 \\
\hline & $\mathrm{C}-2 \mathrm{MN}$ & 10371594 & 4365790 & 150 \\
\hline & TOTAL MN & & & 29.5 \\
\hline & 1-E, 2-EN & 1934977 & 4365790 & 280 \\
\hline & $2,6,2,7 \mathrm{DMN}$ & 2828655 & 4365790 & 4.10 \\
\hline & $1,3,1,7 \mathrm{DMN}$ & 4230445 & 4365790 & 6.13 \\
\hline & $1,6 \mathrm{DMN}$ & 4568165 & 4365790 & 6.62 \\
\hline & $1,4,1,3,1,5 \mathrm{DMN}$ & 3341949 & 4365790 & 4.84 \\
\hline & $1,8 \mathrm{DMN}$ & 1545861 & 4365790 & 2.24 \\
\hline & TOTAL DMN & & & 26.7 \\
\hline & $1,3,7 \mathrm{MN}$ & 1560133 & 4365790 & 2.26 \\
\hline & $1,3,6 \mathrm{TMN}$ & 2427486 & 4365790 & 3.52 \\
\hline & $1,4,6,1,3,5 \mathrm{MMN}$ & 1558479 & 4365790 & 2.26 \\
\hline & $2,3,6 \mathrm{TMN}$ & 889399 & 4365790 & 1.29 \\
\hline & $1,2,7 ; 1,6,7,1,2,6 \mathrm{TMN}$ & 2226052 & 4365790 & 3.23 \\
\hline & $1,2,5 \mathrm{TMN}$ & 983905 & 4365790 & 1.43 \\
\hline & TOTAL TMN & & & 140 \\
\hline & TOTAL NAPHS & & & 83.1 \\
\hline \multirow[t]{14}{*}{ PHENANTHRENES } & PHENANTHRENE & 1483752 & 4373503 & 2.15 \\
\hline & ANTHRACENE & N/A & N/A & N/A \\
\hline & 3.MP & 441580 & 4373503 & 0.639 \\
\hline & $2+\mathrm{MP}$ & 554167 & 4373503 & 0.802 \\
\hline & $2-\mathrm{MA}$ & $\mathrm{N} / \mathrm{A}$ & $\mathrm{N} / \mathrm{A}$ & $\mathrm{N} / \mathrm{A}$ \\
\hline & 9.MP & 660907 & 4373503 & 0.956 \\
\hline & $1-\mathrm{MP}$ & 841547 & 4373503 & 1.22 \\
\hline & $1-\mathrm{MP}+1-\mathrm{MA}$ & $\mathrm{N} / \mathrm{A}$ & $\mathrm{N} / \mathrm{A}$ & $\mathrm{N} / \mathrm{A}$ \\
\hline & $9 \mathrm{MA}$ & $\mathrm{N} / \mathrm{A}$ & N/A & N/A \\
\hline & TOTAL MP & & & 3.61 \\
\hline & TOTAL MP $+M A$ & $\mathrm{~N} / \mathrm{A}$ & $\mathrm{N} / \mathrm{A}$ & $\mathrm{N} / \mathrm{A}$ \\
\hline & TOTAL DMP & 2168783 & 4373503 & 3.14 \\
\hline & TOTAL DMP+DMA & $\mathrm{N} / \mathrm{A}$ & $N / A$ & $\mathrm{~N} / \mathrm{A}$ \\
\hline & TOTAL PHENAS & & & 12.5 \\
\hline
\end{tabular}




\begin{tabular}{|c|c|c|c|c|}
\hline & Cons & Pk Area & IS Pk Area & (ag/g) \\
\hline \multirow{15}{*}{ HOPANES } & $c 29 \alpha \beta$ & 2745842 & 33441710 & 0.520 \\
\hline & $C 29 \beta \alpha$ & 615351 & 33332139 & 0.117 \\
\hline & $\cos 0 \alpha \beta$ & 5460970 & 33441710 & 1.03 \\
\hline & $\cos 0 \beta \alpha$ & 1202182 & 33441710 & 0227 \\
\hline & $C 31 \alpha \beta(S)$ & 2137325 & 33332139 & 0406 \\
\hline & $C 3 \operatorname{lo} \beta(\mathrm{R})$ & 1558419 & 33332139 & 0296 \\
\hline & $C 32 \alpha \beta(S)$ & 1184718 & 33332139 & 0225 \\
\hline & $C 32 \alpha \beta(R)$ & 1184052 & 33332139 & 0.225 \\
\hline & $C 33 \alpha \beta(S)$ & 2103667 & 33441710 & 0.398 \\
\hline & $\mathrm{C} 33 \alpha \beta(\mathrm{R})$ & 2016253 & 33441710 & 0.381 \\
\hline & $C 34 \alpha \beta(S)$ & 1480777 & 33441710 & 0280 \\
\hline & $\mathrm{C} 34 \alpha \beta(\mathrm{R})$ & 1224751 & 33441710 & 0.232 \\
\hline & $C 35 \alpha \beta(S)$ & 1127899 & 33441710 & 0213 \\
\hline & C35aß(R) & 1569736 & 33441710 & 0.297 \\
\hline & TOTAL & & & 4.85 \\
\hline & & & & \\
\hline \multirow[t]{8}{*}{ MONO AROMATICS } & $5 \beta(\mathrm{H}) 27(20 S)$ & 1929384 & 31483024 & 0388 \\
\hline & $5 \beta(H) C 27(20 R)$ & 2438240 & 31483024 & 0490 \\
\hline & 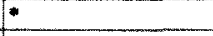 & 6828664 & 31483024 & 137 \\
\hline & $+*$ & 14127236 & 31483024 & 2.84 \\
\hline & $5 \alpha(\mathrm{H}) \mathrm{C} 29(20 \mathrm{~S})$ & 4148854 & 31483024 & 0.834 \\
\hline & $* \infty+$ & 6270943 & 31483024 & 1.26 \\
\hline & $50(\mathrm{H}) \mathrm{C}_{2} 9(20 \mathrm{R})$ & 2524306 & 31483024 & 0.507 \\
\hline & TOTAL & & & 7.69 \\
\hline \multirow[t]{10}{*}{ TRI AROMATICS } & C26(20S) & 5141517 & 31450347 & 1.03 \\
\hline & $C 26(20 R)+C 27(20 S)$ & 11339565 & 31450347 & 2.28 \\
\hline & $C 28(205)$ & 6800739 & 39744391 & 1.08 \\
\hline & $\mathrm{C} 27(2 \mathrm{OR})$ & 6250150 & 39744391 & 0.995 \\
\hline & $\mathrm{C} 28(20 \mathrm{R})$ & 10212420 & 31450347 & 205 \\
\hline & ToTAL & & & 7.45 \\
\hline & & & & \\
\hline & - $\quad 5 \times(\mathrm{H}) 27(20 \mathrm{~S})$ & $\mathrm{C} 28(20 \mathrm{~S})$ & & \\
\hline & * $50(1) C 27(20 \mathrm{R})+$ & $28(20 S)+5 \beta$ & $\beta C 29(20 S)$ & \\
\hline & **. $5 \alpha(1) \mathrm{C} 28(20 \mathrm{R})+$ & $29(20 \mathrm{R})$ & & \\
\hline
\end{tabular}




\begin{tabular}{|c|c|c|c|c|}
\hline & \multicolumn{3}{|c|}{ SFE OF POSIDONIA SHALE AT $150^{\circ} \mathrm{C}$} & \\
\hline & \multicolumn{3}{|c|}{$\mathrm{B}$} & \\
\hline & \multicolumn{3}{|c|}{ Weight of sample $-30013 \mathrm{~g}$} & \\
\hline & \multicolumn{3}{|c|}{ Weight of IS (squalane) $=950 \mathrm{ug}$} & \\
\hline & \multicolumn{3}{|c|}{ Density of supercritical $\mathrm{CO}_{2}=0.548 \mathrm{~g} / \mathrm{ml}$} & \\
\hline & & & & \\
\hline & Comp & Pk Area & IS Pk Area & $(u g / g)$ \\
\hline \multirow[t]{26}{*}{ ALKANES } & $\mathrm{ClO}$ & 1051697 & 1864254 & 1.79 \\
\hline & $\mathrm{Cll}$ & 1141274 & 1864254 & 1.94 \\
\hline & $\mathrm{C} 12$ & 1329507 & 1864254 & 2.26 \\
\hline & $\mathrm{Cl3}$ & 1417340 & 1864254 & 2.41 \\
\hline & C14 & 1604071 & 1864254 & 272 \\
\hline & CIS & 1541864 & 1864254 & 2.72 \\
\hline & C16 & 1528565 & 1864254 & 2.60 \\
\hline & $\mathrm{Cl7+PRI}$ & 6341933 & 1864254 & 108 \\
\hline & $\mathrm{Cl}$ & 1261266 & 1864254 & 2.14 \\
\hline & PHY & 2578042 & 1864254 & 4.38 \\
\hline & C19 & 1090642 & 1864254 & 1.85 \\
\hline & $\mathrm{C} 20$ & 992355 & 1864254 & 1.68 \\
\hline & $\mathrm{C} 21$ & 920489 & 1864254 & 1.56 \\
\hline & $C 22$ & 880471 & 1864254 & 149 \\
\hline & $C 23$ & 852501 & 1864254 & 1.45 \\
\hline & $\mathrm{C24}$ & 1009170 & 1864254 & 1.71 \\
\hline & C25 & 878148 & 1864254 & 1.49 \\
\hline & $\mathrm{C} 26$ & 1199362 & 1864254 & 2.04 \\
\hline & 827 & 756049 & 1864254 & 1.28 \\
\hline & $\mathrm{C} 28$ & 597415 & 2016526 & 0.938 \\
\hline & $\mathrm{C} 29$ & 454152 & 2016526 & 0.713 \\
\hline & $\mathrm{C} 30$ & 503777 & 2016526 & 0.791 \\
\hline & $\mathrm{C} 31$ & 567750 & 2016526 & 0.891 \\
\hline & C32 & 480271 & 2016526 & 0.754 \\
\hline & $\mathrm{C} 33$ & 521670 & 2016526 & 0.819 \\
\hline & TOTAL ALKANES & & & 53.2 \\
\hline \multirow[t]{19}{*}{ NAPHTHALENES } & NAPHTHALENE & 1756509 & 2006502 & 2.77 \\
\hline & $\mathrm{C}-1 \mathrm{MN}$ & 2335690 & 2006502 & 3.68 \\
\hline & $\mathrm{C}-2 \mathrm{MN}$ & 3316281 & $200650 ?$ & 523 \\
\hline & TOTAL MN & & & 8.92 \\
\hline & $1-E, 2-E N$ & 610507 & 2006502 & 0.963 \\
\hline & 2,$6 ; 2$, TDMN & 801004 & 2006502 & 126 \\
\hline & 1,$3 ; 1,7 \mathrm{DMN}$ & 1384203 & 2006502 & 2.18 \\
\hline & $1,6 \mathrm{DMN}$ & 1707578 & 2006502 & 2.69 \\
\hline & $1,4,1,3,1,5 \mathrm{DMN}$ & 1347678 & 2006502 & 2.13 \\
\hline & $1,8 \mathrm{DMN}$ & 593796 & 2006502 & 0.937 \\
\hline & TOTAL DMN & & & 10.2 \\
\hline & $1,3,7 \mathrm{TMN}$ & 630161 & 2006502 & 0.994 \\
\hline & $1,3,6 \mathrm{MMN}$ & 1025670 & 2006502 & 1.62 \\
\hline & $1,4,6,1,3,5 \mathrm{TMN}$ & 759051 & 2006502 & 1.20 \\
\hline & $2.3 .6 \mathrm{TMN}$ & 328255 & 2006502 & 0.518 \\
\hline & $1,2,7,1,6,7,1,2,6 \mathrm{NMN}$ & 1010204 & 2006502 & 1.59 \\
\hline & $1,2,5 \mathrm{MMN}$ & 503162 & 2006502 & 0.794 \\
\hline & TOTAL TMN & & & 6.71 \\
\hline & TOTAL NAPHS & & & 28.6 \\
\hline \multirow[t]{14}{*}{ PHENANTHRENES } & PHENANTTRENE & 437240 & 2030415 & 0.682 \\
\hline & ANTIRACENE & $\mathrm{N} / \mathrm{A}$ & N/A & $N / A$ \\
\hline & $3-M P$ & 231083 & 2030415 & 0.360 \\
\hline & 2MP & 284052 & 2030415 & 0.443 \\
\hline & 2-MA & $N / A$ & $N / A$ & $\mathrm{~N} / \mathrm{A}$ \\
\hline & $9-M P$ & 368072 & 2030415 & 0.574 \\
\hline & $1-M P$ & 548988 & 2030415 & 0.856 \\
\hline & $1-M P+1-M A$ & $N / A$ & N/A & $\mathrm{N} / \mathrm{A}$ \\
\hline & $9 \mathrm{MA}$ & $\mathrm{N} / \mathrm{A}$ & $\mathrm{N} / \mathrm{A}$ & $\mathrm{N} / \mathrm{A}$ \\
\hline & TOTAL MP & & & 2.23 \\
\hline & TOTAL MP+MA & $N / A$ & $\mathrm{~N} / \mathrm{A}$ & $N / A$ \\
\hline & TOTAL DMP & 1081117 & 2030415 & 1.69 \\
\hline & TOTAL DMP +DMA & $N / A$ & & $N / A$ \\
\hline & TOTAL PHENAS & & & 4.60 \\
\hline
\end{tabular}




\begin{tabular}{|c|c|c|c|c|}
\hline & Comp & Pk Ares & IS Pk Area & $(\mathrm{ug} / \mathrm{g})$ \\
\hline \multirow[t]{15}{*}{ HOPANES } & $\mathrm{C} 29 \alpha \beta$ & 9008688 & 48802729 & 0.584 \\
\hline & $\mathrm{C} 29 \beta \alpha$ & 2085712 & 48802729 & 0.135 \\
\hline & $\cos \alpha \beta$ & 15243042 & 48802729 & 0.989 \\
\hline & $\mathrm{C} 30 \beta \alpha$ & 3201706 & 48802729 & 0.208 \\
\hline & $C 3 \operatorname{la} \beta(S)$ & 6047396 & 48802729 & 0.392 \\
\hline & C3l $\alpha \beta(R)$ & 4552257 & 48802729 & 0.295 \\
\hline & $c 32 \alpha \beta(S)$ & 3107218 & 48802729 & 0.202 \\
\hline & $C 32 \alpha \beta(\mathrm{R})$ & 2949348 & 48802729 & 0.191 \\
\hline & $\mathrm{C} 33 \alpha \beta(\mathrm{S})$ & 4976224 & 48802729 & 0.323 \\
\hline & $\mathrm{C} 33 \alpha \beta(\mathrm{R})$ & 4643633 & 48802729 & 0.301 \\
\hline & $\mathrm{C} 34 \alpha \beta(\mathrm{S})$ & 2772858 & 48802729 & 0.180 \\
\hline & $C 34 \alpha \beta(R)$ & 2711428 & 48802729 & 0.176 \\
\hline & $\cos \alpha \alpha \beta(S)$ & 2107005 & 48802729 & 0.137 \\
\hline & $\mathrm{C} 35 \alpha \beta(\mathrm{R})$ & 2624173 & 48802729 & 0.170 \\
\hline & TOTAL & & & 4.28 \\
\hline \multirow[t]{9}{*}{ MONO AROMATICS } & $5 \beta(\mathrm{H}) 27(20 \mathrm{~S})$ & 5846325 & 42423554 & 0.436 \\
\hline & $5 \mathrm{~B}(\mathrm{H} \times \mathrm{C} 27(20 \mathrm{R})$ & 7073953 & 42423554 & 0.528 \\
\hline & $* 4$ & 22513911 & 42423554 & 168 \\
\hline & $+*$ & 39989398 & 42423554 & 2.98 \\
\hline & $5 \alpha(\mathrm{H} \times 29(20 \mathrm{~S})$ & $1495277 !$ & 42423554 & 1.12 \\
\hline & $* * *$ & 21084130 & 42423554 & 1.57 \\
\hline & $50(\mathrm{H}) \mathrm{C} 29(20 \mathrm{R})$ & 8007240 & 42423554 & 0.597 \\
\hline & TOTAL & & & 8.91 \\
\hline & & & & \\
\hline \multirow[t]{10}{*}{ TRI AROMATICS } & $C 26(205)$ & 12092257 & 34016936 & 113 \\
\hline & $\mathrm{C} 26(20 \mathrm{R})+\mathrm{C} 27(20 \mathrm{~S})$ & 23977502 & 33937653 & 2.24 \\
\hline & C28(20S) & 15567397 & 33937653 & 145 \\
\hline & $\mathrm{C} 27(20 \mathrm{R})$ & 13141739 & 34016936 & 1.22 \\
\hline & $\mathrm{C} 28(20 \mathrm{R})$ & 16627104 & 34016936 & 1.55 \\
\hline & TOTAL & & & 7.58 \\
\hline & & & & \\
\hline & \multicolumn{2}{|c|}{ - $\quad 5 \alpha(\mathrm{H}) 27(20 \mathrm{~S})+5 \beta(\mathrm{H}) 28(20 \mathrm{~S})$} & & \\
\hline & \multicolumn{3}{|c|}{ *: $5 \alpha(\mathrm{HC} 27(20 \mathrm{R})+5 \alpha(\mathrm{H}) 28(20 \mathrm{~S})+5 \beta(\mathrm{HCC} 28(20 \mathrm{R})+5 \beta \mathrm{C} 29(20 \mathrm{~S})$} & \\
\hline & \multicolumn{2}{|c|}{ **:50(H)C28(20R)+5B(H)C29(20R) } & & \\
\hline
\end{tabular}




\begin{tabular}{|c|c|c|c|c|}
\hline & \multicolumn{3}{|c|}{ SFE OF POSIDONLA SHALE AT $250^{\circ} \mathrm{C}$} & \\
\hline & \multicolumn{3}{|c|}{ B } & \\
\hline & \multicolumn{3}{|c|}{ Weight of sample $=3.0013_{3}$} & \\
\hline & Weight of & alane $)=9.50$ & & \\
\hline & \multicolumn{3}{|c|}{ Density of supercritical $\mathrm{CO}_{2}=0.366 \mathrm{~g} / \mathrm{ml}$} & \\
\hline & & & & \\
\hline & Comp & Pk Area & Is Pk Area & (ug/g) \\
\hline \multirow[t]{27}{*}{ ALKANES } & C10 & 377165 & 2282068 & 0523 \\
\hline & $\mathrm{C11}$ & 346374 & 2282068 & 0.480 \\
\hline & $\mathrm{C} 12$ & 397539 & 2282068 & 0.551 \\
\hline & $\mathrm{C} 13$ & 487191 & 2282068 & 0.676 \\
\hline & $\mathrm{Cl} 4$ & 422339 & 2282058 & 0.586 \\
\hline & $\mathrm{Cl5}$ & 413888 & 2282068 & 0.574 \\
\hline & $\mathrm{Cl} 6$ & 404611 & 2282068 & 0.561 \\
\hline & $\mathrm{Cl} 7+\mathrm{PRI}$ & 1536311 & 2282068 & 2.13 \\
\hline & $\mathrm{Cl} 8$ & 363523 & 2282068 & 0504 \\
\hline & $\mathrm{PHY}$ & 644948 & 2282068 & 0.895 \\
\hline & $\mathrm{Cl}$ & 367141 & 2282068 & 0509 \\
\hline & $\mathrm{C20}$ & 358516 & 2282068 & 0497 \\
\hline & $\mathrm{C} 21$ & 308857 & 2282058 & 0428 \\
\hline & $\mathrm{C} 22$ & 296479 & 2282068 & 0411 \\
\hline & $\mathrm{C} 23$ & 324518 & 2282068 & 0.450 \\
\hline & $\mathrm{C24}$ & 410971 & 2282068 & 0.570 \\
\hline & $\mathrm{C} 25$ & 341681 & 2282068 & 0.474 \\
\hline & $\mathrm{C} 26$ & 341082 & 2282068 & 0473 \\
\hline & $C 27$ & 225919 & 2282068 & 0.313 \\
\hline & $\mathrm{C} 28$ & 332358 & 2282068 & 0.461 \\
\hline & $\mathrm{C} 29$ & 162796 & 2282068 & 0.226 \\
\hline & $\mathrm{C} 30$ & 174558 & 2282068 & 0.242 \\
\hline & $\mathrm{C} 31$ & 225831 & 2282068 & 0.313 \\
\hline & $\mathrm{C32}$ & 130513 & 2304760 & 0.179 \\
\hline & $\mathrm{C} 33$ & 138258 & 2304760 & 0.190 \\
\hline & TOTAL ALKANES & & & 13.2 \\
\hline & & & & \\
\hline \multirow[t]{19}{*}{ NAPITTLALENES } & NAPHTHALENE & 2995464 & 2308722 & 4.11 \\
\hline & $\mathrm{C}-1 \mathrm{MN}$ & 3424470 & 2308722 & 4.70 \\
\hline & $\mathrm{C} \cdot 2 \mathrm{MN}$ & 3519708 & 2308722 & 483 \\
\hline & TOTAL MN & & & 9.52 \\
\hline & $1-E, 2-E N$ & 901880 & 2308722 & 1.24 \\
\hline & $2,6,2,7 \mathrm{DMN}$ & 1621827 & 2308722 & 2.22 \\
\hline & 1,$3 ; 1,7 \mathrm{DMN}$ & 2067453 & 2308722 & 283 \\
\hline & $1,6 \mathrm{DMN}$ & 2367069 & 2308722 & 3.25 \\
\hline & $1,4,1,3: 1,5 \mathrm{DMN}$ & 1674471 & 2308722 & 230 \\
\hline & $1.8 \mathrm{DMN}$ & 953976 & 2308722 & 1.31 \\
\hline & TOTAL DMN & & & 131 \\
\hline & $1,3,7 \mathrm{MN}$ & 885776 & 2308722 & 1.21 \\
\hline & $1,3,6 \mathrm{MMN}$ & 1045920 & 2308722 & 1.43 \\
\hline & $1,4,6,1,3,5 \mathrm{TMN}$ & 807143 & 2308722 & 1.11 \\
\hline & $2,3,6 \mathrm{TMN}$ & 500732 & 2308722 & 0.687 \\
\hline & $1,2,7,1,6,7,1,2,6 \mathrm{TMN}$ & 1197096 & 2308722 & 1.64 \\
\hline & $1,2.5 \mathrm{TMN}$ & 509089 & 2308722 & 0.698 \\
\hline & TOTAL TMN & & & 6.78 \\
\hline & TOTAL NAPHS & & & 33.6 \\
\hline \multirow[t]{14}{*}{ PHENANTHRENES } & PHENANTHRENE & 1148831 & 2399943 & 1.52 \\
\hline & ANTHRACENE & $\mathrm{N} / \mathrm{A}$ & N/A & $N / A$ \\
\hline & 3-MP & 332150 & 2399943 & 0.438 \\
\hline & 2-MP & 385353 & 2399943 & 0.508 \\
\hline & 2-MA & $N / A$ & $\mathrm{NA}$ & $\mathrm{N} / \mathrm{A}$ \\
\hline & 9MP & 475307 & 2399943 & 0.627 \\
\hline & I-MP & 1140488 & 2399943 & 1.50 \\
\hline & $1-\mathrm{MP}+1-\mathrm{MA}$ & N/A & N/A & $\mathrm{N} / \mathrm{A}$ \\
\hline & $9 \mathrm{MA}$ & $\mathrm{N} / \mathrm{A}$ & $\mathrm{N} / \mathrm{A}$ & $\mathrm{N} / \mathrm{A}$ \\
\hline & TOTAL MP & & & 308 \\
\hline & TOTAL MP $+\mathrm{MA}$ & $\mathrm{N} / \mathrm{A}$ & N/A & $\mathrm{N} / \mathrm{A}$ \\
\hline & TOTAL DMP & 1260401 & 2399943 & 1.66 \\
\hline & TOTAL DMP+DMA & N/A & $\mathrm{N} / \mathrm{A}$ & $\mathrm{N} / \mathrm{A}$ \\
\hline & TOTAL PHENAS & & & 6.25 \\
\hline
\end{tabular}




\begin{tabular}{|c|c|c|c|c|}
\hline & Coms & PkAren & IS Pk Aren & (ug/g) \\
\hline \multirow[t]{15}{*}{ HOPANES } & $C 29 \alpha \beta$ & 1951565 & 45800188 & 0.135 \\
\hline & $c 29 \beta \alpha$ & 261680 & 45800188 & 0018 \\
\hline & c30ap & 1240798 & 45800188 & 0.086 \\
\hline & C30pa & 206093 & 45800188 & 0.014 \\
\hline & C3lap(s) & 592474 & 45800188 & 0.041 \\
\hline & $C 31 \alpha \beta(R)$ & 441198 & 45800188 & 0.030 \\
\hline & $C 32 \alpha \beta(S)$ & 269039 & 45800188 & 0.019 \\
\hline & $\cos \alpha \beta(\mathrm{R})$ & 296966 & 45800188 & 0.021 \\
\hline & $c 33 \alpha \beta(S)$ & 301378 & 45800188 & 0.021 \\
\hline & $C 33 \alpha \beta(R)$ & 370632 & 45800188 & 0.026 \\
\hline & $C 34 \alpha \beta(S)$ & 157120 & 45800188 & 0.011 \\
\hline & $C 34 \alpha \beta(R)$ & 206616 & 45800188 & 0.014 \\
\hline & C $35 \alpha \beta(S)$ & 135549 & 45800188 & 0.009 \\
\hline & C $35 \alpha \beta(R)$ & 167791 & 45800188 & 0.012 \\
\hline & TOTAL & & & 0.456 \\
\hline \multirow[t]{8}{*}{ MONO AROMATICS } & $5 \beta(\mathrm{H}) \subset 27(20 \mathrm{~S})$ & 286992 & 45800188 & 0.020 \\
\hline & $5 \beta(H) C 27(20 R)$ & 358727 & 45800188 & 0025 \\
\hline & * & 1100007 & 45800188 & 0076 \\
\hline & $*$ & 1862599 & 45800188 & 0.129 \\
\hline & $5 \alpha(\mathrm{H}) \mathrm{C} 29(20 \mathrm{~S})$ & 608002 & 45800188 & 0.042 \\
\hline & $\$+$ & 562911 & 45800188 & 0.039 \\
\hline & $5 a(\mathrm{H}) 2920 \mathrm{R})$ & 286482 & 45800188 & 0.020 \\
\hline & TOTAL & & & 0.350 \\
\hline \multirow[t]{10}{*}{ TRI AROMATICS } & $026(205)$ & 1132495 & 44812919 & 0.080 \\
\hline & $C 26(20 R)+C 27(20 S)$ & 1756969 & 44812919 & 0.124 \\
\hline & $\mathrm{C} 28(20 \mathrm{~S})$ & 989412 & 44812919 & 0.070 \\
\hline & $\mathrm{C} 27(20 \mathrm{R})$ & 937240 & 44812919 & 0.066 \\
\hline & $\mathrm{C} 28(20 \mathrm{R})$ & 907679 & 44812919 & 0.064 \\
\hline & TOTAL & & & 0.404 \\
\hline & & & & \\
\hline & \multicolumn{2}{|c|}{$=\quad 5 \alpha(7) C 27(20 S)+5 \beta(H) C 28(20 S)$} & & \\
\hline & \multicolumn{3}{|c|}{ **: $5 \alpha(H) C 27(20 \mathrm{R})+50(\mathrm{HDC} 28(20 \mathrm{~S})+5 \beta(\mathrm{H}) \mathrm{C} 28(20 \mathrm{R})+5 \beta \mathrm{C} 29(20 \mathrm{~S})$} & \\
\hline & ***.50/H)C28(20R)+ & $9(20 \mathrm{R})$ & & \\
\hline
\end{tabular}




\begin{tabular}{|c|c|c|c|c|}
\hline & \multicolumn{3}{|c|}{ SFE OF POSIDONIA SHALE AT350 } & \\
\hline & \multicolumn{3}{|c|}{ B } & \\
\hline & \multicolumn{3}{|c|}{ Weight of sample $-30013 \mathrm{~g}$} & \\
\hline & \multicolumn{3}{|c|}{ Weight of LS (squalane) $1899 \mathrm{ug}$} & \\
\hline & \multicolumn{3}{|c|}{ Densify of supercritucal $\mathrm{CO}_{2}=0.281 \mathrm{~g} / \mathrm{mL}$} & \\
\hline & & & & \\
\hline & Comp & Pk Ares & IS Pk Area & $(\mathrm{ug} / \mathrm{g})$ \\
\hline \multirow[t]{25}{*}{ ALKANES } & $\mathrm{ClO}$ & 476561 & 3082218 & 0.978 \\
\hline & Cll & 604238 & 3109705 & 1.23 \\
\hline & $\mathrm{C} 12$ & 552104 & 3109705 & 1.12 \\
\hline & $\mathrm{C} 13$ & 634104 & 3109705 & 129 \\
\hline & $\mathrm{Cl4}$ & 458454 & 3109705 & 0.933 \\
\hline & C15 & 413959 & 3109705 & 0.842 \\
\hline & C16 & 348349 & 3082218 & 0.715 \\
\hline & $\mathrm{C} 17$ & 392475 & 3082218 & 0.806 \\
\hline & $\mathrm{CI8}$ & 195157 & 3082218 & 0401 \\
\hline & $\mathrm{C} 19$ & 206741 & 3095263 & 0.423 \\
\hline & $\mathrm{C} 20$ & 266112 & 3095263 & 0.544 \\
\hline & $\mathrm{C} 21$ & 251100 & 3095263 & 0.513 \\
\hline & $\mathrm{C} 22$ & 206084 & 3095263 & 0.421 \\
\hline & $\mathrm{C} 23$ & 247289 & 3095263 & 0.506 \\
\hline & $\mathrm{C} 24$ & 213455 & 3095263 & 0.436 \\
\hline & $\mathbf{C 2 5}$ & 227237 & 3095263 & 0.455 \\
\hline & $\mathrm{C} 26$ & 257731 & 3095263 & 0.527 \\
\hline & $\mathrm{C} 27$ & 163746 & 3095263 & 0.335 \\
\hline & $\mathrm{C} 28$ & 187732 & 3095263 & 0.384 \\
\hline & $\mathrm{C} 29$ & 174301 & 3095263 & 0.356 \\
\hline & $\mathrm{C} 30$ & 139856 & 3095263 & 0.286 \\
\hline & C.31 & 154434 & 3095263 & 0.316 \\
\hline & $\mathrm{C} 32$ & 125618 & 3095263 & 0.257 \\
\hline & C33 & N.D. & & 0.000 \\
\hline & TOTAL ALKANES & & & 14.1 \\
\hline \multirow{19}{*}{ NAPHTHALENES } & NAPHTHALENE & 3299356 & 3058639 & 6.83 \\
\hline & $\mathrm{C} \cdot 1 \mathrm{MN}$ & 7568049 & 3058639 & 15.7 \\
\hline & $\mathrm{C}-2 \mathrm{MN}$ & 4770786 & 3058639 & 9.87 \\
\hline & TOTAL MN & & & 25.5 \\
\hline & $1-E, 2-E N$ & 1723913 & 3058639 & 3.57 \\
\hline & $2,6,2,7 \mathrm{DMN}$ & 4839113 & 3058639 & 10.0 \\
\hline & $1,3,1,7 \mathrm{DMN}$ & 5692463 & 3058639 & 11.8 \\
\hline & $1,6 \mathrm{DMN}$ & 3550031 & 3058639 & 7.34 \\
\hline & $1,4,1,3,1,5 \mathrm{DMN}$ & 3031297 & 3058639 & 6.27 \\
\hline & $1,8 \mathrm{DMN}$ & 1436531 & 3058639 & 297 \\
\hline & TOTAL DMN & & & 419 \\
\hline & $1,3,7 \mathrm{MN}$ & 4004946 & 3058639 & 8.28 \\
\hline & $1,3,6 \mathrm{MMN}$ & 4341704 & 3058639 & 8.98 \\
\hline & $1,4,6,1,3,5 \mathrm{TNN}$ & 2802356 & 3058639 & 5.80 \\
\hline & $2,3,6 \mathrm{MMN}$ & 2862114 & 3058639 & $\$ .92$ \\
\hline & $1,2,7,1,6,7,1,2,6 \mathrm{MMN}$ & 5054060 & 3058639 & 10.5 \\
\hline & $1,2,5 \mathrm{TMN}$ & 724790 & 3058639 & 1.50 \\
\hline & TOTAL TMN & & & 40.9 \\
\hline & TOTAL NAPILS & & & 115 \\
\hline \multirow[t]{14}{*}{ PHENANTHRENES } & PHENANTHRENE & 1946732 & 3082229 & 4.00 \\
\hline & ANIIRACENE & 796431 & 3082229 & 1.63 \\
\hline & $3-\mathrm{MP}$ & 1291918 & 3082229 & 2.65 \\
\hline & 2-MP & 1668016 & 3082229 & 342 \\
\hline & 2-MA & 835195 & 3082229 & 1.71 \\
\hline & 9-MP & 1569189 & 3082229 & 3.22 \\
\hline & $1-\mathrm{MP}$ & N/A & $N / A$ & $\mathrm{~N} / \mathrm{A}$ \\
\hline & $1+\mathrm{MP}+1-\mathrm{MA}$ & 3130860 & 3082229 & 6.43 \\
\hline & 9MA & 251719 & 3123383 & 0.510 \\
\hline & TOTAL MP & $\mathrm{N} / \mathrm{A}$ & N/A & N/A \\
\hline & TOTAL MP+MA & & & 17.9 \\
\hline & TOTAL DMP & $\mathrm{N} / \mathrm{A}$ & $\mathrm{N} / \mathrm{A}$ & $N / A$ \\
\hline & TOTAL DMP+DMA & 12430341 & 3082229 & 25.5 \\
\hline & TOTAL PHENAS & & & 49.1 \\
\hline
\end{tabular}




\begin{tabular}{|c|c|c|c|c|}
\hline & Comp & Pk Ares & IS Pk Ares & $(u g / g)$ \\
\hline \multirow[t]{15}{*}{ HOPANES } & $\mathrm{C} 29 a \beta$ & 729425 & 51808388 & 0.089 \\
\hline & 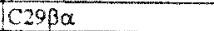 & 171912 & 51808388 & 0.021 \\
\hline & C30aß & 180864 & 51808388 & 0,022 \\
\hline & $\mathrm{C} 30 \beta \alpha$ & 96732 & 51808388 & 0012 \\
\hline & $C 31 \alpha \beta(S)$ & 42244 & 52162268 & 0005 \\
\hline & $C 3 \ln \beta(R)$ & 91448 & 51808388 & 0.011 \\
\hline & $C 32 \alpha \beta(S)$ & 22327 & 52162268 & 0.003 \\
\hline & $\mathrm{C} 32 \alpha \beta(\mathrm{R})$ & 69486 & 52162268 & 0008 \\
\hline & $C 33 \alpha \beta(S)$ & N/A & N/A & N/A \\
\hline & $\mathrm{C} 33 \alpha \beta(\mathrm{R})$ & N/A & N/A & $\mathrm{N} / \mathrm{A}$ \\
\hline & $\mathrm{C} 34 \alpha \beta(\mathrm{S})$ & N/A & N/A & $\mathrm{N} / \mathrm{A}$ \\
\hline & $C 34 \alpha \beta(R)$ & N/A & $N^{\prime} A$ & $\mathrm{~N} / \mathrm{A}$ \\
\hline & $\mathrm{C} 35 \alpha \beta(\mathrm{S})$ & $\mathrm{N} / \mathrm{A}$ & N/A & $\mathrm{N} / \mathrm{A}$ \\
\hline & $C 35 \alpha \beta(R)$ & N/A & $\mathrm{N} / \mathrm{A}$ & N/A \\
\hline & TOTAL & & & 0.171 \\
\hline \multirow{8}{*}{ MONO AROMATICS } & $5 \beta(\mathrm{H}) \mathrm{C} 27(20 \mathrm{~S})$ & $\mathrm{N} / \mathrm{A}$ & $\mathrm{N} / \mathrm{A}$ & $\mathrm{N} / \mathrm{A}$ \\
\hline & $50(\mathrm{H} \times 27(20 \mathrm{R})$ & $\mathrm{N} / \mathrm{A}$ & $\mathrm{N} / \mathrm{A}$ & $\mathrm{N} / \mathrm{A}$ \\
\hline & 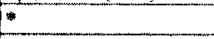 & $\mathrm{N} / \mathrm{A}$ & N/A & $\mathrm{N} / \mathrm{A}$ \\
\hline & $* *$ & N/A & N/A & $\mathrm{N} / \mathrm{A}$ \\
\hline & $5 \alpha(\mathrm{H}) \mathrm{C} 29(20 \mathrm{~S})$ & $\mathrm{N} / \mathrm{A}$ & $\mathrm{N} / \mathrm{A}$ & N/A \\
\hline & $+\infty$ & $\mathrm{N} / \mathrm{A}$ & N/A & N/A \\
\hline & $5 \alpha(\mathrm{H} \times 229(20 \mathrm{R})$ & $\mathrm{N} / \mathrm{A}$ & $\mathrm{N} / \mathrm{A}$ & $\mathrm{N} / \mathrm{A}$ \\
\hline & TOTAL & & & N/A \\
\hline \multirow{10}{*}{ TRI AROMATICS } & $\mathrm{C} 26(20 \mathrm{~S})$ & 34335 & 51810806 & 0.004 \\
\hline & $\mathrm{C} 26(20 \mathrm{R})+\mathrm{C} 27(20 \mathrm{~S})$ & 80560 & 51810806 & 0010 \\
\hline & $C 28(205)$ & 36446 & 52162268 & 0.004 \\
\hline & $\mathrm{C} 27(20 \mathrm{R})$ & 28441 & $\$ 2162268$ & 0.003 \\
\hline & $\mathrm{C} 28(20 \mathrm{R})$ & 47825 & 52162268 & 0.006 \\
\hline & TOTAL & & & 0.028 \\
\hline & & & & \\
\hline & \multicolumn{2}{|c|}{ * $\quad 5 \alpha(\mathrm{HC} 27(20 \mathrm{~s})+5 \beta(\mathrm{H}) \mathrm{C} 28(20 \mathrm{~S})$} & & \\
\hline & \multicolumn{3}{|c|}{ ** $5 \alpha(\mathrm{H}) 27(20 \mathrm{R})+5 \alpha(\mathrm{H}) \mathrm{C} 28(20 \mathrm{~S})+5 \beta(\mathrm{H}) \mathrm{C} 28(20 \mathrm{R})+5 \beta \mathrm{C} 29(20 \mathrm{~S})$} & \\
\hline & $* * * .5 a(H) C 28(20 R)+5$ & $9(20 R)$ & & \\
\hline
\end{tabular}




\begin{tabular}{|c|c|c|c|c|}
\hline & \multicolumn{3}{|c|}{ SFE OF POSWOONLA SHLALE AT $50^{\circ} \mathrm{C}$} & \\
\hline & \multicolumn{3}{|c|}{ c } & \\
\hline & \multicolumn{3}{|c|}{ Weight of sample $=29967 \mathrm{~g}$} & \\
\hline & \multicolumn{3}{|c|}{ Weight of IS (squalane) $=18.99 \mathrm{ug}$} & \\
\hline & \multicolumn{3}{|c|}{ Density of supercritical $\mathrm{CO}_{2}=0.904 \mathrm{~g} / \mathrm{ml}$} & \\
\hline & & & & \\
\hline & Comp & Pk Area & IS Pk Area & $\left(u g^{\prime} g\right)$ \\
\hline \multirow[t]{26}{*}{ ALKANES } & $\mathrm{Cl} 10$ & 2198543 & 1011354 & 13.8 \\
\hline & $\mathrm{Cll}$ & 2213465 & 1011354 & 13.9 \\
\hline & $\mathrm{Cl} 2$ & 1823103 & 1011354 & 114 \\
\hline & $\mathrm{Cl3}$ & 2095294 & 1011354 & 131 \\
\hline & $\mathrm{Cl} 4$ & 2108676 & 1011354 & 132 \\
\hline & C15 & 2200026 & 1011354 & 13.8 \\
\hline & $\mathrm{Cl} 6$ & 2064952 & 1011354 & 129 \\
\hline & $\mathrm{Cl} 7+\mathrm{PRI}$ & 6534248 & 1011354 & 40.9 \\
\hline & $\mathrm{C} 18$ & 1656305 & 1011354 & 10.4 \\
\hline & $\mathrm{PHY}$ & 2327777 & 1011354 & 146 \\
\hline & $\mathrm{Cl} 9$ & 1331338 & 1011354 & 8.34 \\
\hline & $\mathrm{C} 20$ & 1020462 & 1011354 & 6.39 \\
\hline & C21 & 849574 & 1011354 & 5.32 \\
\hline & $\mathrm{C} 22$ & 664851 & 1011354 & 4.17 \\
\hline & $\mathrm{C} 23$ & 640342 & 1011354 & 401 \\
\hline & $\mathrm{C} 24$ & 644207 & 1011354 & 4.04 \\
\hline & $\mathrm{C} 25$ & 532974 & 1011354 & 334 \\
\hline & $\mathrm{C} 26$ & 433202 & 1011354 & 271 \\
\hline & $\mathrm{C} 27$ & 309641 & 1011354 & 1.94 \\
\hline & $\mathrm{C} 28$ & 301090 & 1011354 & 1.89 \\
\hline & $\mathrm{C} 29$ & 271541 & 1011354 & 1.70 \\
\hline & $\mathrm{C} 30$ & 285163 & 1011354 & 1.79 \\
\hline & $\mathrm{C31}$ & 165245 & 1011354 & 1.04 \\
\hline & $\mathrm{C32}$ & 124995 & 1011354 & 0.783 \\
\hline & $\mathrm{C} 33$ & 106987 & 1011354 & 0670 \\
\hline & TOTAL ALKANES & & & 206 \\
\hline \multirow[t]{19}{*}{ NAPITTHALENES } & NAPHTHALENE & 1862860 & 1035504 & 114 \\
\hline & $\mathrm{C}-1 \mathrm{MN}$ & 2344099 & 1035504 & 143 \\
\hline & $\mathrm{C}-2 \mathrm{MN}$ & 2110834 & 1035504 & 129 \\
\hline & TOTAL MN & & & 27.3 \\
\hline & $1-\mathrm{E}, 2-\mathrm{EN}$ & 416329 & 1035504 & 2.55 \\
\hline & $2,6,2,7 \mathrm{DMN}$ & 665369 & 1035504 & 407 \\
\hline & $1,3,1, \mathrm{TDMN}$ & 907746 & 1035504 & 5.56 \\
\hline & $1,6 \mathrm{DMN}$ & 874310 & 1035504 & 5.35 \\
\hline & 1,$4 ; 1,3 ; 1,5 \mathrm{DMN}$ & 725457 & 1035504 & 444 \\
\hline & $1.8 \mathrm{DMN}$ & 327468 & 1035504 & 200 \\
\hline & TOTAL DMN & & & 24.0 \\
\hline & $1,3,7 \mathrm{MN}$ & 307996 & 1035504 & 1.88 \\
\hline & $1,3,6 \mathrm{MMN}$ & 455135 & 1035504 & 2.79 \\
\hline & $1,4,6,1,3,5 \mathrm{TMN}$ & 299557 & 1035504 & 183 \\
\hline & $2,3,6 \mathrm{TMN}$ & 192784 & 1035504 & 118 \\
\hline & $1,2,7,1,6,7,1,2,6 \mathrm{MMN}$ & 448430 & 1035504 & 2.74 \\
\hline & $1,2,5 \mathrm{TMN}$ & 214988 & 1035504 & 132 \\
\hline & TOTAL MMN & & & 117 \\
\hline & TOTAL NAPHS & & & 74.4 \\
\hline \multirow[t]{14}{*}{ PHENANTHRENES } & PHENANTHRENE & 431900 & 1134383 & 241 \\
\hline & ANTHRACENE & $\mathrm{N} / \mathrm{A}$ & $N / A$ & $\mathrm{~N} / \mathrm{A}$ \\
\hline & 3-MP & 121779 & 1134383 & 0.680 \\
\hline & $2 M P$ & 131118 & 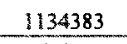 & 0.732 \\
\hline & $2-\mathrm{MA}$ & N/A & N/A & $N / A$ \\
\hline & 9-MP & 162543 & 1134383 & 0.908 \\
\hline & 1-MP & 203634 & 1134383 & 1.14 \\
\hline & $1-M P+1 \cdot M A$ & N/A & $\mathrm{N} / \mathrm{A}$ & $\mathrm{N} / \mathrm{A}$ \\
\hline & $9 \mathrm{MA}$ & $\mathrm{N} / \mathrm{A}$ & $\mathrm{N} / \mathrm{A}$ & $\mathrm{N} / \mathrm{A}$ \\
\hline & TOTAL MP & & & 3.46 \\
\hline & TOTAL MP+MA & $N / A$ & $N / A$ & $N / A$ \\
\hline & TOTAL DMP & 378638 & 1134383 & 2.12 \\
\hline & TOTAL DMP+DMA & $\mathrm{N} / \mathrm{A}$ & 1134383 & $\mathrm{~N} / \mathrm{A}$ \\
\hline & TOTAL PHENAS & & & 7.99 \\
\hline
\end{tabular}




\begin{tabular}{|c|c|c|c|c|}
\hline & Come & PkAre & IS Pk Area & $(u g / g)$ \\
\hline \multirow[t]{15}{*}{ HOPANES } & $\mathrm{C} 29 \alpha \mathrm{p}$ & 7525220 & 89230864 & 0.534 \\
\hline & C298a & 1819715 & 89230864 & 0.129 \\
\hline & C30x & 13567265 & 89230864 & 0.964 \\
\hline & C30pa & 3039272 & 89230864 & 0.216 \\
\hline & $C 31 \alpha \beta(S)$ & 5346868 & 89230864 & 0.380 \\
\hline & $C 31 \alpha \beta(R)$ & 3951015 & 89230864 & 0.281 \\
\hline & $\mathrm{C} 32 \alpha \beta(\mathrm{S})$ & 3030250 & 89230864 & 0.215 \\
\hline & $C 32 \alpha \beta(R)$ & 3761979 & 89230864 & 0.196 \\
\hline & $C 33 \alpha \beta(S)$ & 4204554 & 89230864 & 0.299 \\
\hline & $C 33 \alpha \beta(R)$ & 4255124 & 89230864 & 0.302 \\
\hline & $C 34 \alpha \beta(S)$ & 2821230 & 89230864 & 0.200 \\
\hline & C34ap(R) & 2682211 & 89230864 & 0.190 \\
\hline & $\mathrm{C} 35 \alpha \beta(\mathrm{S})$ & 1956968 & 89230864 & 0.139 \\
\hline & C35 $\alpha \beta(R)$ & 2724109 & 89230864 & 0.193 \\
\hline & TOTAL & & & 424 \\
\hline & & & & \\
\hline \multirow[t]{8}{*}{ MONO AROMATICS } & $5 \beta(H)(2720 \mathrm{~S})$ & 4514693 & 82430906 & 0.347 \\
\hline & $5 \beta(\mathrm{H}) \mathrm{C27}(20 \mathrm{R})$ & 5903060 & 83430006 & 0.454 \\
\hline & 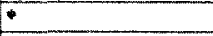 & 16633256 & 82430906 & 1.28 \\
\hline & क* & 31321627 & 82430906 & 241 \\
\hline & $50(\mathrm{H}) \mathrm{C} 29(20 \mathrm{~S})$ & 9714047 & 82430906 & 0747 \\
\hline & $* 4$ & 15449281 & 82430906 & 119 \\
\hline & $5 \alpha(\mathrm{H}) \mathrm{C} 29(20 \mathrm{R})$ & 6523614 & 82430906 & 0.502 \\
\hline & TOTAL & & & 6.92 \\
\hline \multirow[t]{10}{*}{ TRI AROMATICS } & $(26,20 \mathrm{~S})$ & 13131149 & 72842098 & 1.14 \\
\hline & $\mathrm{C} 26(20 \mathrm{R})+\mathrm{C} 27(20 \mathrm{~S})$ & 31807715 & 72842098 & 2.77 \\
\hline & $\mathrm{C} 28(20 S)$ & 19713367 & 72842098 & 1.71 \\
\hline & $\mathrm{C} 27(20 \mathrm{R})$ & 20881996 & 72842098 & 182 \\
\hline & $\mathrm{C} 28(20 \mathrm{R})$ & 29903037 & 72842098 & 2.60 \\
\hline & TOTAL & & & 10.0 \\
\hline & & & & \\
\hline & \multicolumn{2}{|c|}{$*: \quad 5 \alpha(\mathrm{H}) \mathrm{C} 27(20 \mathrm{~S})+5 \beta(\mathrm{H}) \mathrm{C} 28(20 \mathrm{~S})$} & & \\
\hline & \multicolumn{3}{|c|}{ *: $5 \alpha(H) C 27(20 \mathrm{R})+5 \alpha(\mathrm{H}) \mathrm{C} 28(20 \mathrm{~S})+5 \beta(\mathrm{H}) 28(20 \mathrm{R})+5 \beta \mathrm{C} 29(20 \mathrm{~S})$} & \\
\hline & \multicolumn{2}{|c|}{$+*+50(\mathrm{H}) 28(20 \mathrm{R})+5 \beta(\mathrm{H}) \mathrm{C} 29(20 \mathrm{R})$} & & \\
\hline
\end{tabular}




\begin{tabular}{|c|c|c|c|c|}
\hline & \multicolumn{3}{|c|}{ SFE OF POSTOONLA SHALE AT $150^{\circ} \mathrm{C}$} & \\
\hline & \multicolumn{3}{|c|}{$C$} & \\
\hline & \multicolumn{3}{|c|}{ Weight of sample $=29967 \mathrm{~g}$} & \\
\hline & \multicolumn{3}{|c|}{ Weight of IS (squalane) $=950 \mathrm{ug}$} & \\
\hline & \multirow{2}{*}{\multicolumn{3}{|c|}{ Dessity of supermucal $\mathrm{CO}_{2}=$}} & \\
\hline & & & & \\
\hline & Comp & Pk Area & IS Pk Area & $(\mathrm{ug} / \mathrm{g})$ \\
\hline \multirow[t]{26}{*}{ ALKANES } & 010 & 722182 & 1677144 & 1.37 \\
\hline & $\mathrm{Cll}$ & 751567 & 1677144 & 1.42 \\
\hline & $\mathrm{C12}$ & 856213 & 1677144 & 162 \\
\hline & $\mathrm{Cl3}$ & 983442 & 1677144 & 1.86 \\
\hline & C14 & 1103917 & 1677144 & 2.09 \\
\hline & CIS & 1194706 & 1677144 & 2.26 \\
\hline & $\mathrm{C} 16$ & 1052141 & 1677144 & 1.99 \\
\hline & $\mathrm{C} 17+\mathrm{PRI}$ & 4837781 & 1677144 & 9.14 \\
\hline & $\mathrm{C} 18$ & 948756 & 1677144 & 1.79 \\
\hline & $\mathrm{PHY}$ & 1936697 & 1677144 & 366 \\
\hline & $\mathrm{C} 19$ & 778774 & 1677144 & 1.47 \\
\hline & $\mathrm{C} 20$ & 644284 & 1677144 & 1.22 \\
\hline & $\mathrm{C} 21$ & 610435 & 1677144 & 1.15 \\
\hline & $\mathrm{C} 22$ & 591230 & 1677144 & 1.12 \\
\hline & $\mathrm{C} 23$ & 620661 & 1677144 & 1.17 \\
\hline & $\mathrm{C} 24$ & 774798 & 1677144 & 1.46 \\
\hline & $\mathrm{C} 25$ & 692173 & 1677144 & 131 \\
\hline & $\mathrm{C} 26$ & 658033 & 1677144 & 1.24 \\
\hline & $\mathrm{C} 27$ & 393475 & 1677144 & 0.744 \\
\hline & $\mathrm{C} 28$ & 468176 & 1835240 & 0.809 \\
\hline & C29 & 350831 & 1835240 & 0.606 \\
\hline & C30 & 408567 & 1835240 & 0.706 \\
\hline & C31 & 461883 & 1835240 & 0.798 \\
\hline & $\mathrm{C} 32$ & 394920 & 1835240 & 0.682 \\
\hline & C 33 & 384615 & 1835240 & 0.664 \\
\hline & TOTAL ALKANES & & & 42.4 \\
\hline \multirow[t]{19}{*}{ NAPHTHALENES } & NAPHTHALENE & 781585 & 1845936 & 1.34 \\
\hline & $\mathrm{C}-1 \mathrm{MN}$ & 1670955 & 1845936 & 2.87 \\
\hline & $\mathrm{C}-2 \mathrm{MN}$ & 2323470 & 1845936 & 3.99 \\
\hline & TOTAL MN & & & 6.86 \\
\hline & $1-E, 2 \cdot E N$ & 505480 & 1845936 & 0.868 \\
\hline & $2,6,2,7 \mathrm{DMN}$ & 648422 & 1845936 & 111 \\
\hline & $1,3,1,7 \mathrm{TMN}$ & 1227330 & 1845936 & 211 \\
\hline & $1.6 \mathrm{DMN}$ & 1443990 & 1845936 & 248 \\
\hline & $1,4,1,3,1,5 \mathrm{DMN}$ & 955734 & 1845936 & 1.64 \\
\hline & $1,8 \mathrm{DMN}$ & 378830 & 1845936 & 0.651 \\
\hline & TOTAL DMN & & & 8.86 \\
\hline & $1,3,7 \mathrm{MMN}$ & 641258 & 1845936 & 110 \\
\hline & $1,3,6 \mathrm{MN}$ & 864635 & 1845936 & 1.48 \\
\hline & $1,4,6,1,3,5 \mathrm{TMN}$ & 777884 & 1845936 & 1.34 \\
\hline & $2,3,6 \mathrm{MM}$ & 269893 & 1845936 & 0464 \\
\hline & $1,2,7,1,6,7 ; 1.2 .6 \mathrm{MM}$ & 885524 & 1845936 & 1.52 \\
\hline & $1,25 \mathrm{TMN}$ & 415390 & 1845936 & 0.713 \\
\hline & TOTAL TMN & & & 6.62 \\
\hline & TOTAL NAPHS & & & 23.7 \\
\hline \multirow[t]{14}{*}{ PHENANTHRENES } & PLENANTHRENE & 694639 & 2048214 & 108 \\
\hline & ANTHRACENE & $\mathrm{N} / \mathrm{A}$ & N/A & $\mathrm{N} / \mathrm{A}$ \\
\hline & 3-MP & 238554 & 2048214 & 0.369 \\
\hline & $2-M P$ & 279824 & 2048214 & 0.433 \\
\hline & $2-\mathrm{MA}$ & $N / A$ & N/A & $\mathrm{N} / \mathrm{A}$ \\
\hline & $9 \mathrm{MP}$ & 430851 & 2048214 & 0.667 \\
\hline & $1-M P$ & 565782 & 2048214 & 0.876 \\
\hline & $1-\mathrm{MP}+1 \times \mathrm{MA}$ & $\mathrm{N} / \mathrm{A}$ & $\mathrm{N} / \mathrm{A}$ & $\mathrm{N} / \mathrm{A}$ \\
\hline & $9 \mathrm{MA}$ & $N / A$ & $N / A$ & $\mathrm{NA}$ \\
\hline & TOTAL MP & & & 2.34 \\
\hline & TOTAL MP $+M A$ & $N / A$ & $\mathrm{~N} / \mathrm{A}$ & $\mathrm{N} / \mathrm{A}$ \\
\hline & TOTAL DMP & 1217800 & 2048214 & 1.88 \\
\hline & TOTAL DMP+DMA & N/A & $\mathrm{N} / \mathrm{A}$ & $\mathrm{NA}$ \\
\hline & TOTAL PHENAS & & & 5.30 \\
\hline
\end{tabular}




\begin{tabular}{|c|c|c|c|c|}
\hline & Comp & PLArea & IS Pk Aren & $(\log / g)$ \\
\hline \multirow[t]{15}{*}{ HOPANES } & $C 29 \alpha \beta$ & 20438113 & 51153676 & 127 \\
\hline & C298a & 3718802 & 58145263 & 0.203 \\
\hline & C30o $\beta$ & 32318326 & 51153676 & 200 \\
\hline & $\mathrm{C} 30 \beta a$ & 6636024 & $\$ 9677131$ & 0.353 \\
\hline & $C 3 \operatorname{lo} \beta(S)$ & 12970529 & 75632117 & 0544 \\
\hline & $C 3 \operatorname{la} \beta(R)$ & 9439336 & 75632117 & 0.396 \\
\hline & $C 32 \alpha \beta(5)$ & 6695584 & 59677131 & 0.356 \\
\hline & $\mathrm{C} 32 \alpha \beta(\mathrm{B})$ & 6642711 & 59677131 & 0.353 \\
\hline & $C 33 \alpha \beta(S)$ & 11202618 & 75632117 & 0470 \\
\hline & $C 33 \alpha \beta(R)$ & 10343064 & 75632117 & 0434 \\
\hline & $C 34 \alpha \beta(S)$ & 5914472 & 75632117 & 0.248 \\
\hline & $C 34 \alpha \beta(R)$ & 5460603 & 75632117 & 0.229 \\
\hline & $\mathrm{C} 35 \alpha \beta(\mathrm{S})$ & 4471634 & 75632117 & 0.187 \\
\hline & C $35 \alpha \beta(R)$ & 5587634 & 75632117 & 0.234 \\
\hline & TOTAL & & & 7.27 \\
\hline \multirow[t]{9}{*}{ MONO AROMATICS } & $5 \beta(\mathrm{H}) \mathrm{C2} 2(20 \mathrm{~S})$ & 7768941 & 51099706 & 0482 \\
\hline & $5 \beta(\mathrm{H} \times 27(20 \mathrm{R})$ & 9807571 & 51099706 & 0.608 \\
\hline & $*$ & 32382149 & 51099706 & 2.01 \\
\hline & $* *$ & 59996759 & 51099706 & 3.72 \\
\hline & $5 \alpha(\mathrm{H}) \mathrm{C} 29(20 \mathrm{~S})$ & 19142998 & 53221587 & 1.14 \\
\hline & $+* *$ & 24971813 & 53221587 & 149 \\
\hline & $5 \alpha(\mathrm{H}) \mathrm{C} 29(20 \mathrm{R})$ & 11474850 & 51099706 & 0.712 \\
\hline & TOTAL & & & 10.2 \\
\hline & & & & \\
\hline \multirow{9}{*}{ TRI AROMATICS } & $\frac{C 26(205)}{C 26(20 R)+C 27(20 s)}$ & $\frac{18157211}{39240214}$ & $\frac{51059086}{50832119}$ & 1.13 \\
\hline & C28(20s) & 24675621 & 50832119 & $\frac{2.45}{1.54}$ \\
\hline & $\mathrm{C} 27(20 \mathrm{R})$ & 25201073 & 62763100 & 1.27 \\
\hline & $\mathrm{C} 28(20 \mathrm{R})$ & 29518435 & 62763100 & 1.49 \\
\hline & TOTAL & & & 7.88 \\
\hline & & & & \\
\hline & \multicolumn{2}{|c|}{ *: $\quad 5 \alpha(H) C 27(205)+5 \beta(\mathrm{H}) \mathrm{C} 28(20 \mathrm{~S})$} & & \\
\hline & \multicolumn{3}{|c|}{ ** $50(\mathrm{H}) \mathrm{C} 27(20 \mathrm{R})+5 \alpha(\mathrm{H}) \mathrm{C} 28(20 \mathrm{~S})+5 \beta(\mathrm{H}) \mathrm{C} 28(20 \mathrm{R})+5 \beta \mathrm{C} 29(20 \mathrm{~S})$} & \\
\hline & $* * 5 \mathrm{ar}(\mathrm{H}) \subset 28(20 \mathrm{R})$ & $2920 R)$ & & \\
\hline
\end{tabular}




\begin{tabular}{|c|c|c|c|c|}
\hline & \multicolumn{3}{|c|}{ SFE OF POSIDONIA SHALE AT $250^{\circ} \mathrm{C}$} & \\
\hline & \multicolumn{3}{|c|}{$\mathrm{C}$} & \\
\hline & \multicolumn{3}{|c|}{ Weighl of sample $29967 \mathrm{~g}$} & \\
\hline & \multicolumn{3}{|c|}{ Weight of LS (squalane) 9.50 ug } & \\
\hline & \multicolumn{3}{|c|}{ Density of supercritical $\mathrm{CO}_{2}=0366 \mathrm{~g} / \mathrm{ml}$} & \\
\hline & & & & \\
\hline & Comp & Pk Ares & IS Pk Ares & $(\mathrm{ug} / \mathrm{g})$ \\
\hline \multirow[t]{26}{*}{ ALKANES } & C10 & 577586 & 4865198 & 0,376 \\
\hline & $\mathrm{Cll}$ & 661871 & 4865198 & 0431 \\
\hline & $\mathrm{C} 12$ & 502603 & 4865198 & 0.327 \\
\hline & $\mathrm{C} 13$ & 717437 & 4856519 & 0.468 \\
\hline & $\mathrm{Cl4}$ & 742624 & 4856519 & 0.485 \\
\hline & $\mathrm{Cls}$ & 719116 & 4856519 & 0.469 \\
\hline & $\mathrm{Cl} 16$ & 647211 & 4856519 & 0422 \\
\hline & C] $7+\mathrm{PRI}$ & 2174223 & 4856519 & 142 \\
\hline & C18 & 531369 & 4856519 & 0347 \\
\hline & PHY & 874004 & 4865198 & 0569 \\
\hline & $\mathrm{C} 19$ & $6+37614$ & 4865198 & 0422 \\
\hline & $\mathrm{C20}$ & 646804 & 4865198 & 0421 \\
\hline & 621 & 560668 & 4865198 & 0.365 \\
\hline & $\mathrm{C} 22$ & 496284 & 4865198 & 0.323 \\
\hline & $\mathrm{C} 23$ & 494065 & 4865198 & 0.322 \\
\hline & $\mathrm{C} 24$ & 636367 & 4865198 & 0.415 \\
\hline & $\mathrm{C} 25$ & 645920 & 4865198 & 0.421 \\
\hline & $\mathrm{C} 26$ & 646020 & 4865198 & 0421 \\
\hline & $\mathrm{C} 27$ & 514343 & 4865198 & 0.335 \\
\hline & $\mathrm{C} 28$ & 422979 & 5006265 & 0.268 \\
\hline & $\mathrm{C} 29$ & 303383 & $\$ 006265$ & 0.192 \\
\hline & $\mathrm{C} 30$ & 303809 & 5006265 & 0.192 \\
\hline & $\mathrm{C} 31$ & 247495 & 5006265 & 0.157 \\
\hline & $\mathrm{C32}$ & 206899 & 5006265 & 0.131 \\
\hline & $\mathrm{C} 33$ & 196268 & 5006265 & 0.124 \\
\hline & TOTAL ALKANES & & & 9.83 \\
\hline \multirow[t]{19}{*}{ NAPHTHALENES } & NAPHTHALENE & 5212289 & 4922950 & 3.36 \\
\hline & $\mathrm{C}+1 \mathrm{MN}$ & 6391448 & 4922950 & 4.12 \\
\hline & $\mathrm{C}-2 \mathrm{MN}$ & $\$ 125473$ & 4922950 & 3.30 \\
\hline & TOTAL MN & & & 7.42 \\
\hline & $1-E, 2 \cdot E N$ & 1585647 & 4922950 & 1.02 \\
\hline & 2,$6 ; 2, \pi \mathrm{DN}$ & 3207364 & 4922950 & 2.07 \\
\hline & $1,3,1,7 \mathrm{DMN}$ & 3769434 & 4922950 & 2.43 \\
\hline & $1,6 \mathrm{DMN}$ & 4239943 & 4922950 & 273 \\
\hline & $1,4,1,3,1,5 \mathrm{DMN}$ & 2778997 & 4922950 & 179 \\
\hline & $1,8 \mathrm{DMN}$ & 1504324 & 4922950 & 0.969 \\
\hline & TOTAL DMN & & & 11.0 \\
\hline & $1,3,7 \mathrm{MM}$ & 1678905 & 4922950 & 108 \\
\hline & $1,3,6 \mathrm{MMN}$ & 2005133 & 4922950 & 129 \\
\hline & $1,4,6,1,3,5 \pi \mathrm{N}$ & 1425126 & 4922950 & 0.918 \\
\hline & $2,3,6 \mathrm{MMN}$ & 1046848 & 4922950 & 0.674 \\
\hline & $1,2,7,1,6,7,1,2,6 \mathrm{TMN}$ & 2425125 & 4922950 & 1.56 \\
\hline & $1,2,5 \mathrm{TMN}$ & 922057 & 4922950 & 0.594 \\
\hline & TOTAL MN & & & 6.12 \\
\hline & TOTAL NAPHS & & & 27.9 \\
\hline \multirow[t]{14}{*}{ PHENANTHRENES } & PHENANTHRENE & 2233527 & 5043922 & 1.40 \\
\hline & ANTHRACENE & $N / A$ & $\mathrm{~N} / \mathrm{A}$ & $\mathrm{N} / \mathrm{A}$ \\
\hline & 3-MP & 757095 & 5043922 & 0.476 \\
\hline & 2-MP & 932095 & 5043922 & 0.586 \\
\hline & 2-MA & $\mathrm{N} / \mathrm{A}$ & $N / A$ & $\mathrm{~N} / \mathrm{A}$ \\
\hline & 9-MP & 912878 & 5043922 & 0.574 \\
\hline & 1-MP & 2104370 & 5043922 & 1.32 \\
\hline & $1-M P+1-M A$ & N/A & $\mathrm{N} / \mathrm{A}$ & $\mathrm{N} / \mathrm{A}$ \\
\hline & $9 \mathrm{MA}$ & $N / A$ & $\mathrm{~N} / \mathrm{A}$ & N/A \\
\hline & TOTAL MP & & & 2.96 \\
\hline & TOTAL MP MA & N/A & $\mathrm{N} / \mathrm{A}$ & $\mathrm{N} / \mathrm{A}$ \\
\hline & TOTAL DMP & 3714174 & 5043922 & 2.33 \\
\hline & TOTAL DMP+DMA & $N / A$ & $\mathrm{~N} / \mathrm{A}$ & N/A \\
\hline & TOTAL PHENAS & & & 6.70 \\
\hline
\end{tabular}




\begin{tabular}{|c|c|c|c|c|}
\hline & Comp & Pk Are & IS PK Aren & $(u g / g)$ \\
\hline \multirow{15}{*}{ HOPANES } & $C 29 \alpha \beta$ & 3456806 & 70154582 & 0156 \\
\hline & $C_{29 \beta \alpha}$ & 538658 & 71906001 & 0.024 \\
\hline & $630 \alpha \beta$ & 2080874 & 70154582 & 0.094 \\
\hline & $\cos 0 \beta$ & 366333 & 71906001 & 0016 \\
\hline & $\mathrm{C} 3 \mid \alpha \beta(S)$ & 1101988 & 71906001 & 0049 \\
\hline & $\mathrm{C} 3 \operatorname{lo} \beta(\mathrm{R})$ & 808703 & 71906001 & 0.036 \\
\hline & $\mathrm{C} 32 \alpha \beta(S)$ & 480951 & 71906001 & 0.021 \\
\hline & $\mathrm{C} 32 \alpha \beta(\mathrm{R})$ & 542265 & 71906001 & 0.024 \\
\hline & $c 33 \alpha \beta(S)$ & 564518 & 71906001 & 0.025 \\
\hline & $C 33 \alpha \beta(R)$ & 734448 & 71906001 & 0.032 \\
\hline & $C 34 \alpha \beta(S)$ & 318976 & 71906001 & 0.014 \\
\hline & $C 34 \alpha \beta(R)$ & 457589 & 71906001 & 0.020 \\
\hline & $\mathrm{C} 35 \alpha \beta(\mathrm{S})$ & 260942 & 71906001 & 0012 \\
\hline & $\mathrm{C} 35 \alpha \beta(\mathrm{R})$ & 358024 & 71906001 & 0.016 \\
\hline & TOTAL & & & 0.538 \\
\hline & & & & \\
\hline \multirow[t]{8}{*}{ MONO AROMATICS } & $5 \beta(\mathrm{H}) \mathrm{C}_{27}(20 \mathrm{~S})$ & 281886 & 71906001 & 0.012 \\
\hline & $5 \rho(\mathrm{H}) \mathrm{C} 27(20 \mathrm{R})$ & 360601 & 71906001 & 0.016 \\
\hline & $*$ & 1167914 & 71906001 & 0.051 \\
\hline & * & 1983851 & 71906001 & 0.087 \\
\hline & $5 \alpha(\mathrm{H} \times 29(20 \mathrm{~S})$ & 659772 & 71906001 & 0.029 \\
\hline & $* * *$ & 970283 & 71906001 & 0.043 \\
\hline & $5 \alpha(\mathrm{H}) \mathrm{C} 29(20 \mathrm{R})$ & 363575 & 71906001 & 0.016 \\
\hline & TOTAL & & & 0.255 \\
\hline \multirow[t]{9}{*}{ TRI AROMATICS } & $\mathrm{C} 26(20 \mathrm{~S})$ & 1918204 & 67972302 & 0.089 \\
\hline & $C 26(20 R)+C 27(20 S)$ & 3088830 & 70154582 & 0.140 \\
\hline & $\mathrm{C} 28(20 \mathrm{~S})$ & 1563857 & 67972302 & 0.073 \\
\hline & $\mathrm{C} 27(20 \mathrm{R})$ & 1696208 & 70154582 & 0077 \\
\hline & $\mathrm{C} 28(20 \mathrm{R})$ & 1756940 & 70154582 & 0.079 \\
\hline & TOTAL & & & 0.458 \\
\hline & \multicolumn{2}{|c|}{ * $\quad 5 \alpha(\mathrm{H}) 2720 \mathrm{~S})+5 \beta(\mathrm{H}) 228(20 \mathrm{~S})$} & & \\
\hline & \multicolumn{3}{|c|}{$* 5 \alpha(H) C 27(20 R)+5 \alpha(H) C 28(20 S)+5 \beta(H) C 28(20 R)+5 \beta C 29(20 S)$} & \\
\hline & \multicolumn{2}{|c|}{$+4.5 \alpha(\mathrm{H}) \mathrm{C} 28(20 \mathrm{R})+5 B(\mathrm{HCC} 29(20 \mathrm{R})$} & & \\
\hline
\end{tabular}




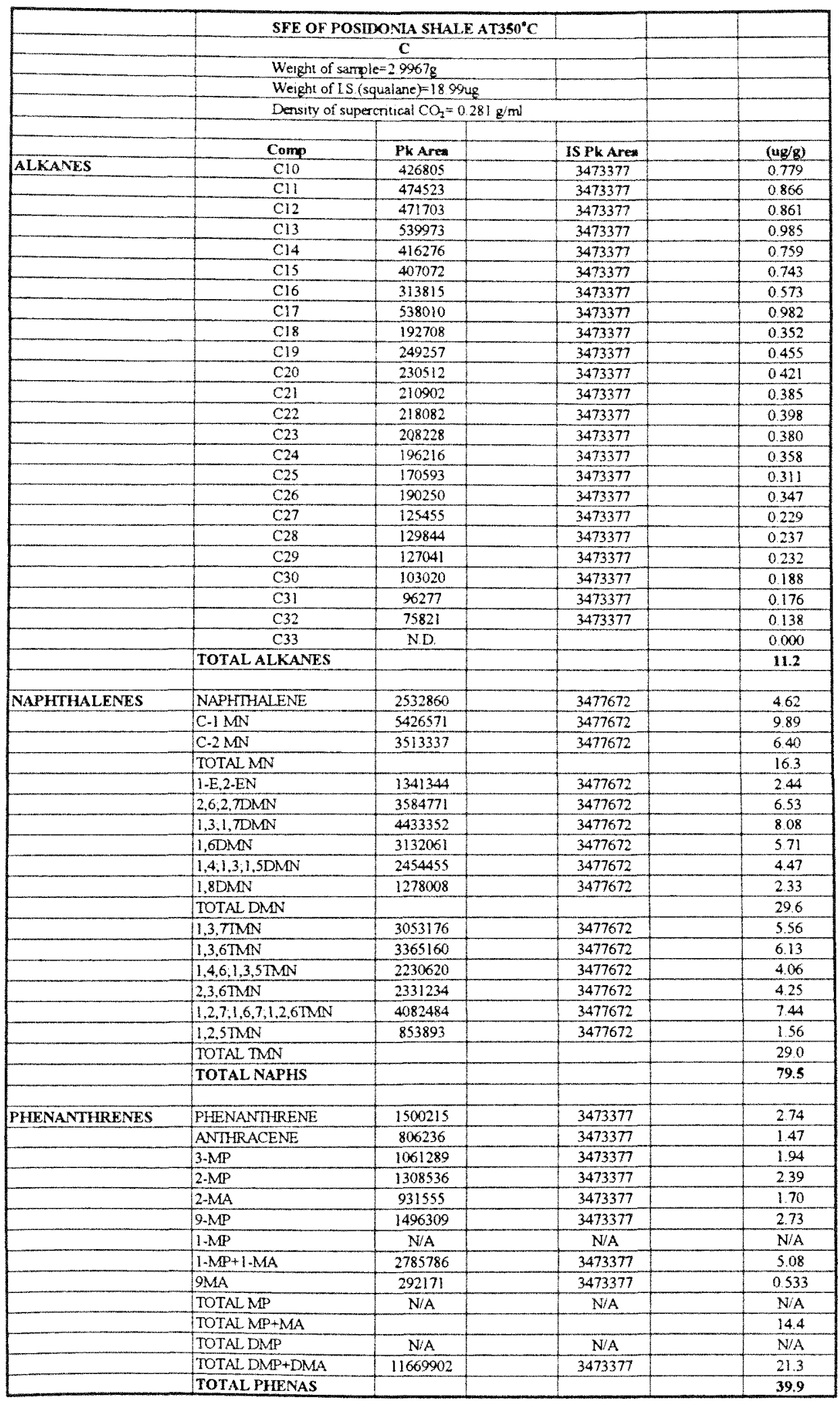




\begin{tabular}{|c|c|c|c|c|}
\hline & Conip & Pk Are & IS Pk Area & $(u g / g)$ \\
\hline \multirow[t]{15}{*}{ HOPANES } & $C 29 \alpha \beta$ & 2130380 & 141849526 & 0.095 \\
\hline & $\mathrm{C} 298 \alpha$ & 554045 & 139899675 & 0.025 \\
\hline & $\mathrm{C} 30 \mathrm{ag}$ & 627004 & 139899675 & 0.028 \\
\hline & c c3opa & 319791 & 139899675 & 0.014 \\
\hline & $\mathrm{C} 31 \alpha \beta(S)$ & 170137 & 139899675 & 0.008 \\
\hline & $C 3 \mid \alpha \beta(R)$ & 332751 & 139899675 & 0015 \\
\hline & $\mathrm{C} 32 \alpha \beta(S)$ & 76456 & 140883025 & 0.003 \\
\hline & $\mathrm{C} 32 \alpha \beta(R)$ & 260333 & 140883025 & 0.012 \\
\hline & $\mathrm{C} 33 \times \beta(\mathrm{S})$ & $\mathrm{N} / \mathrm{A}$ & N/A & N/A \\
\hline & $\mathrm{C} 33 \alpha \beta(\mathrm{R})$ & $\mathrm{N} / \mathrm{A}$ & N/A & N/A \\
\hline & $C 34 \alpha \beta(S)$ & N/A & N/A & N/A \\
\hline & $C 34 \alpha \beta(R)$ & $\mathrm{N} / \mathrm{A}$ & $\mathrm{N} / \mathrm{A}$ & $\mathrm{N} / \mathrm{A}$ \\
\hline & $\mathrm{C} 35 \alpha \beta(S)$ & N/A & $\mathrm{N} / \mathrm{A}$ & NA \\
\hline & $C 35 \alpha \beta(R)$ & $\mathrm{N} / \mathrm{A}$ & N/A & $\mathrm{N} / \mathrm{A}$ \\
\hline & TOTAL & & & 0.201 \\
\hline \multirow[t]{8}{*}{ MONO AROMATICS } & $S B(\mathrm{H}) C 27(20 \mathrm{~S})$ & N/A & $\mathrm{N} / \mathrm{A}$ & $\mathrm{N} / \mathrm{A}$ \\
\hline & $S \beta(\mathrm{H}) \mathrm{C} 27(20 \mathrm{R})$ & $\mathrm{N} / \mathrm{A}$ & $\mathrm{N} / \mathrm{A}$ & $\mathrm{N} / \mathrm{A}$ \\
\hline & $*$ & $\mathrm{~N} / \mathrm{A}$ & N/A & N/A \\
\hline & $*$ & $\mathrm{~N} / \mathrm{A}$ & $\mathrm{N} / \mathrm{A}$ & $N / A$ \\
\hline & $5 \alpha(\mathrm{H}) 29(20 \mathrm{~S})$ & $\mathrm{N} / \mathrm{A}$ & $\mathrm{N} / \mathrm{A}$ & $N / A$ \\
\hline & *** & N/A & N/A & $\mathrm{N} / \mathrm{A}$ \\
\hline & $5 a(\mathrm{H}) 29(20 \mathrm{R})$ & $\mathrm{N} / \mathrm{A}$ & $\mathrm{N} / \mathrm{A}$ & NA \\
\hline & TOTAL & & & $\mathbf{N A}$ \\
\hline \multirow{10}{*}{ TRI AROMATICS } & $\mathrm{C} 26(205)$ & 48890 & 140883025 & 0.002 \\
\hline & $\mathrm{C} 26(20 \mathrm{R})+\mathrm{C} 27(20 \mathrm{~S})$ & 115781 & 140883025 & 0.005 \\
\hline & $\mathrm{C} 28(20 \mathrm{~S})$ & 181877 & 140883025 & 0.008 \\
\hline & C27(20R) & $5688 \%$ & 140883025 & 0.003 \\
\hline & $C 28(20 \mathrm{R})$ & 196012 & 140883025 & 0.009 \\
\hline & TOTAL & & & 0.027 \\
\hline & & & & \\
\hline & \multicolumn{2}{|c|}{$: \quad 5 \alpha(H) C 27(20 S)+5 \beta(H) C 28(20 S)$} & & \\
\hline & \multicolumn{3}{|c|}{ **: $5 \alpha(\mathrm{H}) \mathrm{C} 27(20 \mathrm{R})+5 \alpha(\mathrm{H}) \mathrm{C} 28(20 \mathrm{~S})+5 \beta(\mathrm{H}) \mathrm{C} 28(20 \mathrm{R})+5 \beta \mathrm{C} 29(20 \mathrm{~S})$} & \\
\hline & $* * * 5 \alpha(\mathrm{H}) \mathrm{C} 28(20 \mathrm{R})$ & $9(20 \mathrm{R})$ & & \\
\hline
\end{tabular}




\begin{tabular}{|c|c|c|c|c|}
\hline & \multicolumn{3}{|c|}{ THERMODESORPTION OF POSIDONLA SHALE AT SOC } & \\
\hline & & A & & \\
\hline & \multicolumn{2}{|c|}{ Weight of sample $=299148$} & & \\
\hline & \multirow{2}{*}{\multicolumn{3}{|c|}{ Weight of IS (squalane)=9 soug }} & \\
\hline & & & & \\
\hline & Comp & PkAres & IS PkAres & $(u g / g)$ \\
\hline \multirow[t]{26}{*}{ ALKANES } & $\mathrm{Clo}$ & ND & & 00000 \\
\hline & Cl1 & N.D. & & 0.0000 \\
\hline & $\mathrm{Cl2}$ & N.D. & & 0.0000 \\
\hline & $\mathrm{Cl3}$ & N.D. & & 0.0000 \\
\hline & $\mathrm{Cl} 4$ & N.D. & & 0.0000 \\
\hline & $\mathrm{Cl5}$ & N.D. & & 00000 \\
\hline & $\mathrm{C16}$ & N.D. & & 0.0000 \\
\hline & $\mathrm{Cl}+\mathrm{PRI}$ & N.D. & & 0.0000 \\
\hline & $\mathrm{Cl}$ & N.D. & & 0.0000 \\
\hline & PHY & N.D. & & 0.0000 \\
\hline & $\mathrm{C} 19$ & N.D. & & 0.0000 \\
\hline & $\mathrm{C} 20$ & ND. & & 0.0000 \\
\hline & $\mathrm{C} 21$ & N.D & & 0.0000 \\
\hline & $\mathrm{C} 22$ & N.D. & & 0.0000 \\
\hline & $\mathrm{C} 23$ & N.D. & & 0.0000 \\
\hline & $\mathrm{C} 24$ & ND & & 0.0000 \\
\hline & $\mathrm{C} 25$ & N.D. & & 0,0000 \\
\hline & $\mathrm{C} 26$ & ND & & 0.0000 \\
\hline & $\mathrm{C} 27$ & N.D. & & 0.0000 \\
\hline & $\mathrm{C} 28$ & N.D. & & 0.0000 \\
\hline & $\mathrm{C} 29$ & N.D. & & 0.0000 \\
\hline & $\mathrm{C} 30$ & N.D. & & 00000 \\
\hline & $\mathrm{C} 31$ & N.D & & 0.0000 \\
\hline & $\mathrm{C} 32$ & N.D & & 0.0000 \\
\hline & $\mathrm{C} 33$ & N.D. & & 0.0000 \\
\hline & TOTAL ALKANES & & & 0.0000 \\
\hline \multirow[t]{19}{*}{ NAPHTHALENES } & NAPHTHALENE & $\mathrm{ND}$ & & 0.0000 \\
\hline & $\mathrm{C}-1 \mathrm{MN}$ & N.D. & & 0.0000 \\
\hline & $\mathrm{C} .2 \mathrm{MN}$ & N.D & & 0.0000 \\
\hline & TOTAL MN & & & 0.0000 \\
\hline & 1-E, 2-EDMN & N.D. & & 0.0000 \\
\hline & $2,6,2, \pi \mathrm{DMN}$ & ND & & 0.0000 \\
\hline & $1,3,1,7 \mathrm{DMN}$ & N.D. & & 0.0000 \\
\hline & $1,6 \mathrm{DMN}$ & N.D & & 0.0000 \\
\hline & $1,4,1,3 ; 1,5 \mathrm{DMN}$ & $\mathrm{ND}$ & & 0.0000 \\
\hline & $1.8 \mathrm{DMN}$ & N.D & & 0.0000 \\
\hline & TOTAL DMN & & & 0.0000 \\
\hline & $1,3,7 \mathrm{MMN}$ & N.D & & 0.0000 \\
\hline & $1,3,6 \mathrm{MN}$ & N.D. & & 0.0000 \\
\hline & $1,4,6,1,3,5 \mathrm{TMN}$ & ND. & & 0.0000 \\
\hline & $2,3,6 \mathrm{TMN}$ & N.D & & 0.0000 \\
\hline & $1,2,7,1,6,7,1,2,6 \mathrm{TMN}$ & N.D. & & 0.0000 \\
\hline & $1,2,5 \mathrm{TMN}$ & ND. & & 0.0000 \\
\hline & TOTAL TMN & & & 0.0000 \\
\hline & TOTAL NAPHS & & & 0.0000 \\
\hline & & & & \\
\hline \multirow[t]{14}{*}{ PHENATTLALENES } & PHENATHLENE & N.D. & & 0.0000 \\
\hline & ANTHRASENE & N.D. & & 0.0000 \\
\hline & $3-\mathrm{MP}$ & ND & & 0.0000 \\
\hline & $2-\mathrm{MP}$ & ND. & & 0.0000 \\
\hline & $2+\mathrm{MA}$ & ND & & 0,0000 \\
\hline & 9-MP & N.D. & & 0.0000 \\
\hline & $1-\mathrm{MP}$ & N.D & & 0.0000 \\
\hline & 1-MP+1-MA & ND & & 0.0000 \\
\hline & $9 \mathrm{MA}$ & N.D & & 0.0000 \\
\hline & TOTAL MP & N.D. & & 0.0000 \\
\hline & TOTAL MP+MA & N.D & & 0.0000 \\
\hline & TOTAL DMP & ND. & & 0.0000 \\
\hline & TOTAL DMP+DMA & ND & & 0.0000 \\
\hline & TOTAL PHENAS & & & 0.0000 \\
\hline
\end{tabular}




\begin{tabular}{|c|c|c|c|c|}
\hline HOPANES & Comp & PkAren & IS PK Area & (ug/g) \\
\hline & $C 29 \alpha \beta$ & ND. & & 0.0000 \\
\hline & $C 29 \beta \alpha$ & ND. & & 0.0000 \\
\hline & $C 30 \alpha \beta$ & N.D. & & 0.0000 \\
\hline & $\mathrm{C} 30 \beta \alpha$ & N.D & & 0,0000 \\
\hline & $\mathrm{C} 31 \alpha \beta(\mathrm{S})$ & NO. & & 0.0000 \\
\hline & $\mathrm{C} 31 \alpha \beta(\mathrm{R})$ & ND. & & 0.0000 \\
\hline & 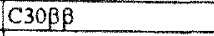 & N.D. & & 0,0000 \\
\hline & $\cos 2 \alpha \beta(S)$ & ND. & & 00000 \\
\hline & $\mathrm{C} 32 \alpha \beta(\mathrm{R})$ & ND. & & 0.0000 \\
\hline & $\mathrm{C} 33 \alpha \mathrm{\rho}(\mathrm{s})$ & ND. & & 0.0000 \\
\hline & $\mathrm{C} 33 \alpha \beta(\mathrm{R})$ & ND. & & 0.0000 \\
\hline & C34a $\beta(S)$ & N.D. & & 0.0000 \\
\hline & $C 34 \alpha \beta(R)$ & N.D. & & 0.0000 \\
\hline & $C 35 \alpha \beta(S)$ & N.D. & & 0.0000 \\
\hline & $\mathrm{C} 35 \alpha \beta(\mathrm{R})$ & N.D. & & 0.0000 \\
\hline & TOTAL & & & 0.0000 \\
\hline MONO AROMATICS & $5 \beta(\mathrm{H}) \mathrm{C} 27(20 \mathrm{~S})$ & N.D. & & 0.0000 \\
\hline & $5 \beta(\mathrm{H}) 227(20 \mathrm{R})$ & ND. & & 0.0000 \\
\hline & $*$ & N.D & & 0.0000 \\
\hline & *\# & N.D & & 0.0000 \\
\hline & $5 \alpha(\mathrm{H}) \mathrm{C} 29(20 \mathrm{~S})$ & N.D & & 0.0000 \\
\hline & $+\infty$ & ND. & & 0.0000 \\
\hline & $5 \alpha(\mathrm{H}) \mathrm{C} 29(2 \mathrm{OR})$ & ND & & 0,0000 \\
\hline & TOTAL & & & 0.0000 \\
\hline TRI AROMATICS & $\mathrm{C} 26(20 \mathrm{~S})$ & ND & & 0.0000 \\
\hline & $\mathrm{C} 26(20 \mathrm{R})+\mathrm{C} 27(20 \mathrm{~S})$ & N.D & & 0.0000 \\
\hline & $\mathrm{C} 28(20 \mathrm{~S})$ & ND. & & 0.0000 \\
\hline & $\mathrm{C} 27(20 \mathrm{R})$ & N.D. & & 0,0000 \\
\hline & $\mathrm{C} 28(20 \mathrm{R})$ & N.D. & & 0.0000 \\
\hline & TOTAL & & & 0.0000 \\
\hline & & & & \\
\hline & \multicolumn{2}{|c|}{$* \quad 5 \alpha(\mathrm{H}) \mathrm{C} 27(\mathrm{~S})+5 \beta(\mathrm{H}) \mathrm{C} 28(\mathrm{~S})$} & & \\
\hline & \multicolumn{3}{|c|}{ * $5 \alpha(\mathrm{H}) \mathrm{C} 27(20 \mathrm{R})+5 \alpha(\mathrm{H}) \mathrm{C} 28(20 \mathrm{~S})+5 \beta(\mathrm{H}) \mathrm{C} 28(20 \mathrm{R})+5 \beta \mathrm{C} 29(20 \mathrm{~S})$} & \\
\hline & \multicolumn{2}{|c|}{$+* * 5 \alpha(\mathrm{H}) \mathrm{C} 28(20 \mathrm{R})+5 \beta(\mathrm{H}) \mathrm{C} 29(20 \mathrm{R})$} & & \\
\hline
\end{tabular}




\begin{tabular}{|c|c|c|c|c|}
\hline & \multicolumn{3}{|c|}{ THERMODESORPTION OF POSIDONIA SHALE AT $150 C$} & \\
\hline & & A & & \\
\hline & \multicolumn{2}{|c|}{ Welght of sample $=2.9914 \mathrm{~g}$} & & \\
\hline & \multirow{2}{*}{\multicolumn{3}{|c|}{ Weight of LS (squalane) $=9.50 \mathrm{ug}$}} & \\
\hline & & & & \\
\hline & Comp & PkAres & IS Pk Area & $(u s / g)$ \\
\hline \multirow{26}{*}{ ALKANES } & $\mathrm{ClO}$ & 3325892 & 2046875 & 5.16 \\
\hline & $\mathrm{Cll}$ & 4840251 & 2046875 & 7.51 \\
\hline & $\mathrm{Cl2}$ & 3575546 & 2046875 & 5.55 \\
\hline & $\mathrm{Cl3}$ & 1903363 & 2046875 & 2.95 \\
\hline & $\mathrm{Cl4}$ & 891211 & 2046875 & 1.38 \\
\hline & C15 & 439363 & 2046875 & 0.682 \\
\hline & $\mathrm{Cl6}$ & ND. & & 0.0000 \\
\hline & $\mathrm{Cl} 1+\mathrm{PRI}$ & N.D. & & 0.0000 \\
\hline & $\mathrm{Cl}$ & N.D. & & 0.00000 \\
\hline & $\mathrm{PHY}$ & N.D & & 0.0000 \\
\hline & $\mathrm{Cl9}$ & N.D. & & 0,0000 \\
\hline & $\mathrm{C} 20$ & N.O. & & 0.0000 \\
\hline & $\mathrm{C} 21$ & N.D. & & 0.0000 \\
\hline & $\mathrm{C22}$ & N.D & & 0.0000 \\
\hline & $\mathrm{C} 23$ & N.D. & & 0.0000 \\
\hline & $\mathrm{C24}$ & N.D. & & 0.0000 \\
\hline & $\mathrm{C} 25$ & N.D. & & 0.0000 \\
\hline & $\mathrm{C} 26$ & N.D. & & 0.0000 \\
\hline & $\mathrm{C} 27$ & N.D. & & 0.0000 \\
\hline & $\mathrm{C} 28$ & N.D. & & 0.0000 \\
\hline & $\mathrm{C} 29$ & $\mathrm{ND}$. & & 0.0000 \\
\hline & $\mathrm{C} 30$ & $\mathrm{ND}$ & & 0.0000 \\
\hline & $\mathrm{C} 3 \mathrm{l}$ & ND & & 0,0000 \\
\hline & $\mathrm{C} 32$ & N.D. & & 0.0000 \\
\hline & $\mathrm{C} 33$ & N.D. & & 0.0000 \\
\hline & TOTAL ALKANES & & & 23.24 \\
\hline \multirow{20}{*}{ NAPHTHALENES } & NAPHTHALENE & 767470 & 2046875 & 1.1907 \\
\hline & $\mathrm{C}-1 \mathrm{MN}$ & $\mathrm{ND}$ & & 0.0000 \\
\hline & $\mathrm{C}-2 \mathrm{MN}$ & ND. & & 0.0000 \\
\hline & TOTAL MN & & & 0.0000 \\
\hline & 1-E,2-EDMN & ND. & & 0.0000 \\
\hline & $2,6,2,7 \mathrm{DMN}$ & N.D. & & 0.0000 \\
\hline & $1,3,1, \mathrm{TDMN}$ & N.D. & & 0.0000 \\
\hline & $1,6 \mathrm{DMN}$ & ND. & & 0,0000 \\
\hline & $1,4,1,3,1,5 \mathrm{DMN}$ & N.D. & & 0.0000 \\
\hline & $1.8 \mathrm{DMN}$ & N.D. & & 00000 \\
\hline & TOTAL DMN & & & 00000 \\
\hline & $1,3,7 \mathrm{mMN}$ & N.D. & & 0.0000 \\
\hline & $1,3,6 \mathrm{TMN}$ & N.D. & & 0.0000 \\
\hline & $1,4,6,1,3,5 \mathrm{TMN}$ & ND. & & 0,0000 \\
\hline & $2,3,6 \mathrm{TMN}$ & ND & & 0.0000 \\
\hline & $1,2,7,1,6,7,1,2,6 \mathrm{TMN}$ & ND & & 0.0000 \\
\hline & $1,2,5 \mathrm{TMN}$ & N.D. & & 0.0000 \\
\hline & TOTAL TMN & & & 0.0000 \\
\hline & TOTAL NAPHS & & & 1.19 \\
\hline & & & & \\
\hline \multirow{14}{*}{ PHENATHALENES } & PHENATHIENE & ND & & 0.0000 \\
\hline & ANTHRASENE & N.D. & & 0.0000 \\
\hline & 3-MP & ND & & 0.0000 \\
\hline & $2-\mathrm{MP}$ & N.D. & & 0.0000 \\
\hline & 2-MA & N.D. & & 0.0000 \\
\hline & 9.MP & N.D. & & 0.0000 \\
\hline & 1-MP & N.D. & & 0.0000 \\
\hline & $1-\mathrm{MP}+1-\mathrm{MA}$ & ND. & & 0.0000 \\
\hline & $9 \mathrm{MA}$ & N.D. & & 0.0000 \\
\hline & TOTAL MP & ND & & 0.0000 \\
\hline & TOTAL MP+MA & ND & & 0.0000 \\
\hline & TOTAL DMP & N.D. & & 0.0000 \\
\hline & TOTAL DMP+DMA & N.D. & & 0.0000 \\
\hline & TOTAL PHENAS & & & 0.0900 \\
\hline
\end{tabular}




\begin{tabular}{|c|c|c|c|c|}
\hline HOPANES & Comn & Pk Area & IS PKArea & (ur/s) \\
\hline & $C 29 \alpha \beta$ & N.D. & & 0.0000 \\
\hline & $C 29 \beta \alpha$ & N.D. & & 0.0000 \\
\hline & $\mathrm{C} 30 \alpha \beta$ & N.D. & & 0.0000 \\
\hline & C30קa & N.D. & & 0,0000 \\
\hline & $C 3 \operatorname{lo} \beta(s)$ & N.D. & & 0.0000 \\
\hline & $C 3 \operatorname{lo} \beta(R)$ & N.D. & & 0.0000 \\
\hline & $C 30 \beta \beta$ & N.D. & & 0.0000 \\
\hline & $\mathrm{C} 32 \alpha \beta(S)$ & ND. & & 0.0000 \\
\hline & $\mathrm{C} 32 \alpha \beta(\mathrm{R})$ & ND. & & 0.0000 \\
\hline & $\mathrm{C} 33 \alpha \beta(\mathrm{S})$ & N.D & & 0.0000 \\
\hline & $C 33 \alpha \beta(R)$ & N.D. & & 0.0000 \\
\hline & $\mathrm{C} 34 \alpha \beta(S)$ & N.D. & & 0.0000 \\
\hline & $C 34 \alpha \beta(R)$ & N.D. & & 0.0000 \\
\hline & $\mathrm{C} 35 \alpha \beta(S)$ & N.D. & & 0.0000 \\
\hline & $C 35 \alpha \beta(R)$ & N.D. & & 0.0000 \\
\hline & TOTAL & & & 0.0000 \\
\hline MONO AROMATICS & $5 \beta(\mathrm{H}) C 27(20 \mathrm{~S})$ & N.D. & & 0.0000 \\
\hline & $5 \beta(\mathrm{H}) \mathrm{C} 27(2 \mathrm{OR})$ & N.D. & & 0.0000 \\
\hline & $*$ & N.D. & & 0.0000 \\
\hline & \# & N.D & & 0.0000 \\
\hline & $5 a(\mathrm{H}) \mathrm{C}_{2} 9(20 \mathrm{~S})$ & N.D. & & 0,0000 \\
\hline & +6 & ND. & & 0.0000 \\
\hline & $5 \alpha(\mathrm{H}) \mathrm{C} 29(20 \mathrm{R})$ & N.D & & 00000 \\
\hline & TOTAL & & & 0.0000 \\
\hline TRI AROMATICS & $\mathrm{C} 26(20 \mathrm{~S})$ & N.D. & & 0.0000 \\
\hline & $\mathrm{C} 26(20 \mathrm{R})+\mathrm{C} 27(20 \mathrm{~S})$ & N.D. & & 0.0000 \\
\hline & $\mathrm{C} 28(20 \mathrm{~S})$ & ND. & & 0.0000 \\
\hline & $\mathrm{C} 27(20 \mathrm{R})$ & ND. & & 0.0000 \\
\hline & C28(20R) & N.D. & & 0.0000 \\
\hline & TOTAL & & & 0.0000 \\
\hline & & & & \\
\hline & \multicolumn{2}{|c|}{ * $\quad S \alpha(H) C 27(S)+5 \beta(H) C 28(S)$} & & \\
\hline & \multicolumn{3}{|c|}{ **: $5 \alpha(\mathrm{H}) 27(20 \mathrm{R})+5 \alpha(\mathrm{H}) \mathrm{C} 28(20 \mathrm{~S})+5 \beta(\mathrm{H}) \mathrm{C} 28(20 \mathrm{R})+5 \beta \mathrm{C} 29(20 \mathrm{~S})$} & \\
\hline & \multicolumn{2}{|c|}{ *w\$ $5 \alpha(\mathrm{HC} 28(20 \mathrm{R})+5 \mathrm{P}(\mathrm{HCC} 29(20 \mathrm{R})$} & & \\
\hline
\end{tabular}




\begin{tabular}{|c|c|c|c|c|}
\hline & \multicolumn{3}{|c|}{ THERMODESORPTION OF POSIDONLA SHALE AT 250C } & \\
\hline & & $\mathrm{A}$ & & \\
\hline & \multicolumn{2}{|c|}{ Weght of sample $=2.9914 \mathrm{~g}$} & & \\
\hline & \multirow{2}{*}{\multicolumn{3}{|c|}{ Weight of IS (squalane) $=9.50 u g$}} & \\
\hline & & & & \\
\hline & Comp & PkAres & IS Pk Ares & $(4 \mathrm{u} / \mathrm{s})$ \\
\hline \multirow{27}{*}{ ALKANES } & Clo & 1329137 & 936604 & 4.51 \\
\hline & $\mathrm{CH}$ & 731252 & 936604 & 248 \\
\hline & $\mathrm{Cl2}$ & 3220426 & 936604 & 1092 \\
\hline & $\mathrm{Cl} 3$ & 3384789 & 9366044 & 1148 \\
\hline & $\mathrm{Cl} 4$ & 2687111 & 936604 & 911 \\
\hline & $\mathrm{Cls}$ & 2245334 & 936604 & 7.61 \\
\hline & $\mathrm{Cl} 6$ & 1555200 & 936604 & 5.27 \\
\hline & $\mathrm{CIT+PRI}$ & 1395089 & 936604 & 4.73 \\
\hline & $\mathrm{C} 18$ & 533278 & 860246 & 1.97 \\
\hline & PHY & 299492 & 931652 & 1.02 \\
\hline & $\mathrm{Cl} 9$ & 307498 & 936604 & 104 \\
\hline & $\mathrm{C} 20$ & 186224 & 936604 & 0.631 \\
\hline & $\mathrm{C} 21$ & ND & & 0.0000 \\
\hline & $\mathrm{C} 22$ & ND & & 0.0000 \\
\hline & $\mathrm{C} 23$ & ND & & 0.0000 \\
\hline & $\mathrm{C} 24$ & ND & & 0.0000 \\
\hline & $\mathrm{C} 25$ & ND & & 0.0000 \\
\hline & $\mathrm{C} 26$ & N/D & & 0.0000 \\
\hline & $\mathrm{C} 27$ & ND & & 0.0000 \\
\hline & $\mathrm{C} 28$ & ND & & 0.0000 \\
\hline & $\mathrm{C} 29$ & ND & & 0.0000 \\
\hline & $\mathrm{C} 30$ & ND & & 0.0000 \\
\hline & C31 & N/D & & 0.0000 \\
\hline & $\mathrm{C} 32$ & ND & & 0.0000 \\
\hline & $\mathrm{C} 33$ & ND & & 0.0000 \\
\hline & TOTAL ALKANES & & & 60.77 \\
\hline & NAPHTHAIENE & 5730437 & 931652 & 19.53 \\
\hline \multirow{19}{*}{ NAPHTHALENES } & $\mathrm{C}-1 \mathrm{MN}$ & 5758147 & 931652 & 19.63 \\
\hline & C-2MN & 4420071 & 931652 & 15.07 \\
\hline & TOTAL MN & & & 34.70 \\
\hline & 1-E,2-EDMN & 892096 & 931652 & 3.04 \\
\hline & $2,6,2,7 \mathrm{OMN}$ & 1427597 & 931652 & 4.87 \\
\hline & $1,3,1,7 \mathrm{DMN}$ & 1471464 & 931652 & 5.02 \\
\hline & $1,6 \mathrm{DMN}$ & 1405244 & 931652 & 4.79 \\
\hline & 1,$4 ; 1,3 ; 1,5 \mathrm{DMN}$ & 1041998 & 931652 & 3.55 \\
\hline & $1,8 \mathrm{DMN}$ & 499301 & 931652 & 1.70 \\
\hline & TOTAL DMN & & & 22.97 \\
\hline & $1,3,7 \mathrm{TMN}$ & 335284 & 931652 & 114 \\
\hline & $1,3,6 \mathrm{TMN}$ & 246810 & 931652 & 0.841 \\
\hline & $1,4,6,1,3,5 \mathrm{TMN}$ & 192501 & 931652 & 0.656 \\
\hline & $2,3,6 \mathrm{mMN}$ & 113098 & 931652 & 0.386 \\
\hline & $1,2,7,1,6,7,1,2,6 \mathrm{MMN}$ & 309083 & 931652 & 1.05 \\
\hline & $1,2,5 \mathrm{TMN}$ & 120978 & 931652 & 04112 \\
\hline & TOTAL TMN & & & 449 \\
\hline & TOTAL NAPHS & & & 81.69 \\
\hline & & & & \\
\hline \multirow[t]{14}{*}{ PHENATHALENES } & PHENATHILENE & 377657 & 931652 & 1.29 \\
\hline & ANTHRASENE & ND & & 0.0000 \\
\hline & $3-\mathrm{MP}^{\mathrm{S}}$ & 62702 & 931652 & 0.214 \\
\hline & $2+\mathrm{MP}$ & 36003 & 931652 & 0.123 \\
\hline & $2-\mathrm{MA}$ & N.D & & 00000 \\
\hline & 9.MP & 73980 & 931652 & 0252 \\
\hline & 1-MP & 98717 & 931652 & 0.337 \\
\hline & 1-MP+1-MA & ND & & 0.0000 \\
\hline & $9 \mathrm{MA}$ & N.D. & & 00000 \\
\hline & TOTAL MP & N.D & & 0.925 \\
\hline & TOTAL MP+MA & N.D & & 0,0000 \\
\hline & TOTAL DMP & ND. & & 0.0000 \\
\hline & TOTAL DMP+DMA & N.D. & & 0.0000 \\
\hline & TOTAL PHENAS & & & 2.21 \\
\hline
\end{tabular}




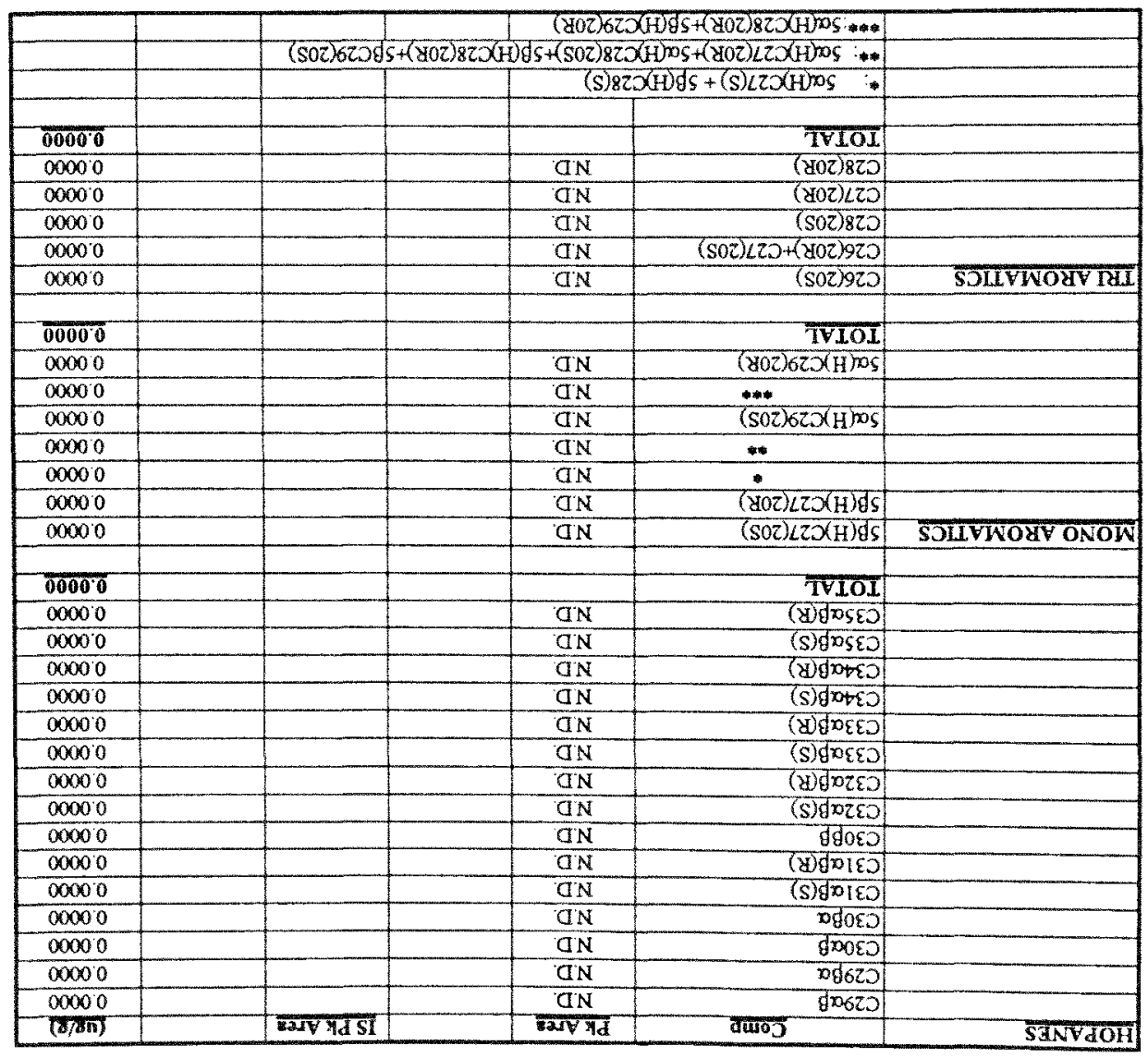




\begin{tabular}{|c|c|c|c|c|}
\hline & \multicolumn{3}{|c|}{ THERMODESORPTION OF POSIDONIA SHALE AT $350 \mathrm{C}$} & \\
\hline & & $\mathrm{A}$ & & \\
\hline & \multicolumn{2}{|c|}{ Weight of sample $=29914 \mathrm{~g}$} & & \\
\hline & \multirow{2}{*}{\multicolumn{3}{|c|}{ Weight of IS (squalane) $=9.5048$}} & \\
\hline & & & & \\
\hline & Comp & PkAre: & IS PkAres & $(u g / x)$ \\
\hline \multirow{26}{*}{ ALKANES } & $\mathrm{ClO}$ & 648082 & 2754192 & 0.747 \\
\hline & $\mathrm{Cl1}$ & 1111707 & 2754192 & 128 \\
\hline & $\mathrm{Cl} 2$ & 1049199 & 2754192 & 1.21 \\
\hline & C13 & 1389535 & 2754192 & 1.60 \\
\hline & $\mathrm{Cl4}$ & 1451336 & 2754192 & 1.67 \\
\hline & C15 & 2166972 & 2754192 & 2.50 \\
\hline & $\mathrm{Cl} 6$ & 2625044 & 2754192 & 3.03 \\
\hline & $\mathrm{Cl} 7+\mathrm{PR}$ & 3295018 & 2754192 & 3.80 \\
\hline & $\mathrm{Cl} 18$ & 2802766 & 2754192 & 3.23 \\
\hline & $\mathrm{PHY}$ & 498666 & 1655836 & 0.956 \\
\hline & $\mathrm{Cl9}$ & 2573645 & 2754192 & 297 \\
\hline & $\mathrm{C} 20$ & 1859756 & 2754192 & 2.14 \\
\hline & $\mathrm{C} 21$ & 1499145 & 2754192 & 1.73 \\
\hline & $\mathrm{C} 22$ & 1186554 & 2754192 & 1.37 \\
\hline & $\mathrm{C} 23$ & 832847 & 2754192 & 0.960 \\
\hline & $\mathrm{C} 24$ & 720728 & 2754192 & 0.831 \\
\hline & $\mathrm{C} 25$ & 457003 & 2754192 & 0.527 \\
\hline & C26 & 355326 & 2754192 & 0410 \\
\hline & $\mathrm{C} 27$ & 165321 & 2754192 & 0191 \\
\hline & $\mathrm{C} 28$ & 118457 & 2754192 & 0.137 \\
\hline & $\mathrm{C} 29$ & ND. & & 0.0000 \\
\hline & C30 & ND. & & 00000 \\
\hline & $\mathrm{C} 31$ & N.D. & & 00000 \\
\hline & $\mathrm{C} 32$ & N.D. & & 0.0000 \\
\hline & $\mathrm{C} 33$ & N.D. & & 00000 \\
\hline & TOTAL ALKANES & & & 31.29 \\
\hline \multirow{19}{*}{ NAPHTHALENES } & NAPHTHALENE & 5437719 & 2728368 & 6.33 \\
\hline & $\mathrm{C}-1 \mathrm{MN}$ & 11937962 & 2728368 & 13.90 \\
\hline & $\mathrm{C}-2 \mathrm{MN}$ & 7325723 & 2728368 & 8.53 \\
\hline & TOTAL MN & & & 22.42 \\
\hline & 1-E,2-EDMN & 2932719 & 2728368 & 3.41 \\
\hline & 26,2, DMN & 9530583 & 2728368 & 11.09 \\
\hline & $1,3,1,7 D M N$ & 10567470 & 2728368 & 12.30 \\
\hline & $1,60 \mathrm{MN}$ & 8122654 & 2728368 & 9.45 \\
\hline & 1,$4 ; 1,3,1,5 \mathrm{DMN}$ & 6387935 & 2728368 & 744 \\
\hline & $1,8 \mathrm{DMN}$ & 2802399 & 2728368 & 3.26 \\
\hline & TOTAL DMN & & & 46.96 \\
\hline & $1,3,7 \mathrm{MMN}$ & 6485947 & 2728368 & 7.55 \\
\hline & $1,3,6 \mathrm{TMN}$ & 7114875 & 2728368 & 8.28 \\
\hline & $1,4,6,1,3,5 \mathrm{TMN}$ & 4733671 & 2728368 & 5.51 \\
\hline & $2,3,6 \mathrm{TMN}$ & 4914779 & 2728368 & 5.72 \\
\hline & $1,2,7,1,6,7,1,2,6 \mathrm{TMN}$ & 9737580 & 2728368 & 11.33 \\
\hline & $1,2,5 \mathrm{TMN}$ & 1914245 & 2728368 & 223 \\
\hline & TOTAL TMN & & & 40.62 \\
\hline & TOTAL NAPHS & & & 116.34 \\
\hline \multirow[t]{14}{*}{ PHENATHALENES } & PHENATHLENE & 4769823 & 2754192 & 5.50 \\
\hline & ANIHRASENE & 2015190 & 2754192 & 2.32 \\
\hline & 3-MP & 2581118 & 2754192 & 2.98 \\
\hline & $2-\mathrm{MP}$ & 2879243 & 2754192 & 3.32 \\
\hline & $2-\mathrm{MA}$ & 2451999 & 2754192 & 2.83 \\
\hline & $9-\mathrm{MP}$ & 2901804 & 2754192 & 3.35 \\
\hline & $1-\mathrm{MP}$ & $\mathrm{N} / \mathrm{A}$ & & $\mathrm{N} / \mathrm{A}$ \\
\hline & $1-\mathrm{MP}^{\mathrm{P}}+1-\mathrm{MA}$ & 5146807 & 2754192 & 5.93 \\
\hline & $9 \mathrm{MA}$ & 507507 & 2754099 & 0.585 \\
\hline & TOTAL MP & & & $\mathrm{N} / \mathrm{A}$ \\
\hline & TOTAL MP+MA & & & 18.99 \\
\hline & TOTAL DMP & $N / A$ & NA & $\mathrm{N} / \mathrm{A}$ \\
\hline & TOTAL DMP+DMA & 17366724 & 2754192 & 20.03 \\
\hline & TOTALPHENAS & & & 46.84 \\
\hline
\end{tabular}




\begin{tabular}{|c|c|c|c|c|}
\hline HOPANES & Comp & PkArea & IS Pk Area & $\left(u p^{\prime g}\right)$ \\
\hline & $\mathrm{C} 29 \alpha \beta$ & N.D. & & 0.0000 \\
\hline & $\mathrm{C} 296 \alpha$ & N.D. & & 00000 \\
\hline & $\mathrm{C} 30 \times \alpha \beta$ & ND. & & 0.0000 \\
\hline & $\mathrm{c} 30 p \alpha$ & N.D. & & 0,0000 \\
\hline & $C 31 \alpha \beta(S)$ & N.D. & & 0.0000 \\
\hline & $\mathrm{C}(\alpha \beta(\mathrm{R})$ & ND. & & 0.0000 \\
\hline & C30BB & N.D. & & 0.0000 \\
\hline & c32ap(s) & N.D. & & 0.0000 \\
\hline & $\mathrm{C} 32 \alpha \beta(\mathrm{R})$ & N.D. & & 0.0000 \\
\hline & $\mathrm{C} 33 \alpha \beta(S)$ & N.D & & 0.0000 \\
\hline & $\mathrm{C} 33 \alpha \beta(R)$ & N.D & & 0.0000 \\
\hline & $\mathrm{C} 34 \alpha \beta(S)$ & ND & & 0,0000 \\
\hline & $C 34 \alpha \beta(R)$ & N.D. & & 0.0000 \\
\hline & $\mathrm{C} 35 \alpha \beta(\mathrm{S})$ & ND. & & 0.0000 \\
\hline & $\mathrm{C} 35 \alpha \beta(R)$ & N.D & & 0.0000 \\
\hline & TOTAL & & & 0.0000 \\
\hline MONO AROMATTCS & $5 \beta(\mathrm{H}) \mathrm{C} 27(20 \mathrm{~S})$ & ND & & 0.0000 \\
\hline & $5 \beta(\mathrm{H}) \mathrm{C} 27(20 \mathrm{R})$ & N.D. & & 0,0000 \\
\hline & - & N.D & & 0,0000 \\
\hline & ** & N.D. & & 0.0000 \\
\hline & $5 \alpha(\mathrm{HCC} 29(20 \mathrm{~S})$ & N.D. & & 0.0000 \\
\hline & 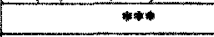 & $\mathrm{ND}$ & & 0.0000 \\
\hline & $5 \alpha(\mathrm{H}) 229(20 \mathrm{R})$ & N.D & & 0.0000 \\
\hline & TOTAL & & & 0.0000 \\
\hline TRI AROMATICS & $\mathrm{C26(20S)}$ & N.D. & & 0,0000 \\
\hline & $\mathrm{C} 26(20 \mathrm{R})+\mathrm{C} 27(20 \mathrm{~S})$ & N.D & & 0.0000 \\
\hline & $\mathrm{C} 28(20 \mathrm{~S})$ & ND. & & 00000 \\
\hline & C27(20R) & ND. & & 0.0000 \\
\hline & C28(20R) & ND. & & 00000 \\
\hline & TOTAL & & & 0.0000 \\
\hline & & & & \\
\hline & \multicolumn{2}{|c|}{ * $5 \alpha(\mathrm{H}) \mathrm{C} 27(\mathrm{~S})+5 \beta(\mathrm{H}) \mathrm{C} 28(\mathrm{~S})$} & & \\
\hline & \multicolumn{3}{|c|}{ * $5 \alpha(\mathrm{H}) \mathrm{C} 27(20 \mathrm{R})+5 \alpha \beta \mathrm{H}) \mathrm{C} 28(20 \mathrm{~S})+5 \beta(\mathrm{H}) \mathrm{C} 28(20 \mathrm{R})+5 \beta \mathrm{C} 29(20 \mathrm{~S})$} & \\
\hline & क* $5 \alpha(\mathrm{H}) \mathrm{C} 28(20 \mathrm{R})+$ & $29(20 \mathrm{R})$ & & \\
\hline
\end{tabular}




\begin{tabular}{|c|c|c|c|c|}
\hline & \multicolumn{3}{|c|}{ TIER MODESORPTION OF POSUOONIA SHALE AT SOC } & \\
\hline & & B & & \\
\hline & \multicolumn{2}{|c|}{ Weight of sample $=3.0150 \mathrm{~g}$} & & \\
\hline & \multirow{2}{*}{\multicolumn{3}{|c|}{ Woght of IS (squalane) $=9.50 \mathrm{ug}$}} & \\
\hline & & & & \\
\hline & Comp & PkArea & IS PkAre: & (ug/R) \\
\hline \multirow[t]{26}{*}{ ALKANES } & $\mathrm{ClO}$ & N.D. & & 00000 \\
\hline & $\mathrm{Cll}$ & N.D & & 0,0000 \\
\hline & $\mathrm{Cl} 2$ & N.D. & & 0,0000 \\
\hline & $\mathrm{Cl}$ & N.D. & & 0.0000 \\
\hline & $\mathrm{Cl} 4$ & ND. & & 0.0000 \\
\hline & $\mathrm{Cls}$ & N.D. & & 0.0000 \\
\hline & $\mathrm{Cl} 16$ & N.D & & 0.0000 \\
\hline & $\mathrm{Cl}+\mathrm{PRI}$ & N.D. & & 0.0000 \\
\hline & $\mathrm{Cl} 8$ & N.D. & & 0.0000 \\
\hline & PHY & $\mathrm{ND}$ & & 0,0000 \\
\hline & $\mathrm{Cl9}$ & N.D. & & 0,0000 \\
\hline & $\mathrm{C} 20$ & N.D. & & 0.0000 \\
\hline & $\mathrm{C} 21$ & N.D. & & 0.0000 \\
\hline & $\mathrm{C} 22$ & $\mathrm{ND}$ & & 0,0000 \\
\hline & $\mathrm{C} 23$ & ND. & & 0.0000 \\
\hline & $\mathrm{C} 24$ & ND & & 0,0000 \\
\hline & $\mathrm{C} 25$ & N.D & & 0.0000 \\
\hline & $\mathrm{C} 26$ & N.D & & 0.0000 \\
\hline & $\mathrm{C} 27$ & ND & & 0.0000 \\
\hline & $\mathrm{C} 28$ & N.D. & & 0.0000 \\
\hline & $\mathrm{C} 29$ & ND. & & 0.0000 \\
\hline & $\mathrm{C} 30$ & ND. & & 0.0000 \\
\hline & $\mathrm{C} 31$ & ND. & & 0.0000 \\
\hline & $\mathrm{C} 32$ & ND. & & 0.0000 \\
\hline & $\mathrm{C} 33$ & N.D. & & 0.0000 \\
\hline & TOTALALKANES & & & 0.0000 \\
\hline \multirow[t]{20}{*}{ NAPHTHALENES } & NAPHTHALENE & ND & & 0.0000 \\
\hline & $\mathrm{C}-1 \mathrm{MN}$ & N.D. & & 0.0000 \\
\hline & $\mathrm{C}-2 \mathrm{MN}$ & N.D. & & 0.0000 \\
\hline & TOTAL MN & & & 0.0000 \\
\hline & 1-E2-EDMN & N.D & & 0.0000 \\
\hline & $2,6,2, \mathrm{TDMN}$ & N.D & & 0.0000 \\
\hline & $1,3,1,7 \mathrm{DMN}$ & N.D & & 0.0000 \\
\hline & $1,6 \mathrm{DMN}$ & ND & & 0,0000 \\
\hline & $1,4,1,3,1,5 \mathrm{DMN}$ & $\mathrm{ND}$ & & 0.0000 \\
\hline & $1.8 \mathrm{DMN}$ & ND & & 0.0000 \\
\hline & TOTAL DMN & & & 0.0000 \\
\hline & $1,3,7 \mathrm{MN}$ & ND & & $0.0000^{\circ}$ \\
\hline & $1,3,6 \mathrm{TMN}$ & N.D & & 0.0000 \\
\hline & $1,4,6,1,3,5 \mathrm{TMN}$ & N.D & & 00000 \\
\hline & $2,3,6 \mathrm{lMN}$ & N.D & & 0.0000 \\
\hline & $1,2,7,1,6,7,1,2,6 \mathrm{TMN}$ & N.D. & & 0.0000 \\
\hline & $1,2,5 \mathrm{TMN}$ & N.D. & & 0.0000 \\
\hline & TOTAL MMN & & & 0.0000 \\
\hline & TOTAL NAPHS & & & 0.0000 \\
\hline & & & & \\
\hline \multirow[t]{14}{*}{ PHENATHALENES } & PHENATHLENE & ND & & 0.0000 \\
\hline & ANTHRASENE & ND & & 00000 \\
\hline & 3-MP & ND & & 0.0000 \\
\hline & $2-\mathrm{MP}$ & N.D & & 0.0000 \\
\hline & $2-\mathrm{MA}$ & N.D & & 0.0000 \\
\hline & 9-MP & N.D. & & 0.0000 \\
\hline & I-MP & ND. & & 0.0000 \\
\hline & 1-MP+1-MA & N.D & & 0.0000 \\
\hline & $9 \mathrm{MA}$ & ND & & 0.0000 \\
\hline & TOTAL MP & N.D. & & 00000 \\
\hline & TOTAL MP+MA & N.D & & 0,0000 \\
\hline & TOTAL DMP & N.D. & & 0,0000 \\
\hline & TOTAL DMP+DMA & ND & & 0.0000 \\
\hline & IOTAL PHENAS & & & 0.0000 \\
\hline
\end{tabular}




\begin{tabular}{|c|c|c|c|c|}
\hline HOPANES & Comp & PkAre & IS Pk Area & $(u \sin )$ \\
\hline & $C 29 a \beta$ & ND & & 00000 \\
\hline & $C 29 \beta \alpha$ & ND & & 00000 \\
\hline & $C 30 \alpha \beta$ & N.D & & 0.0000 \\
\hline & $\mathrm{C} 30 \mathrm{~B} \alpha$ & ND & & 0.0000 \\
\hline & $\mathrm{C3} \operatorname{lo} \beta(\mathrm{S})$ & N.D & & 0.0000 \\
\hline & $\mathrm{C} 31 \alpha \beta(\mathrm{R})$ & N.D & & 00000 \\
\hline & C30BB & N.D & & 00000 \\
\hline & $\mathrm{C} 32 \alpha \beta(S)$ & N.D & & 0.0000 \\
\hline & $\mathrm{C} 32 \alpha \beta(R)$ & N.D & & 0.0000 \\
\hline & $\mathrm{C} 33 \mathrm{a \beta}(\mathrm{s})$ & ND & & 0.0000 \\
\hline & $\mathrm{C} 33 \alpha \rho(R)$ & N.D & & 0.0000 \\
\hline & $C 34 \alpha \beta(\mathrm{S})$ & N.D & & 0.0000 \\
\hline & $\mathrm{C} 34 \alpha \beta(R)$ & ND & & 0.0000 \\
\hline & $\mathrm{C} 35 \alpha \beta(\mathrm{S})$ & ND & & 0.0000 \\
\hline & $\mathrm{C} 35 \alpha \beta(R)$ & ND & & 0.0000 \\
\hline & TOTAL & & & 0.0000 \\
\hline \multirow[t]{8}{*}{ MONO AROMATICS } & $5 \beta(\mathrm{H}) \mathrm{C27}(20 \mathrm{~S})$ & ND. & & 0.0000 \\
\hline & $5 \beta(\mathrm{H}) \subset 27(20 \mathrm{R})$ & ND. & & 0.0000 \\
\hline & $*$ & ND & & 0.0000 \\
\hline & $*$ & ND. & & 0.0000 \\
\hline & $50(\mathrm{H}) \mathrm{C} 29(20 \mathrm{~S})$ & N.D. & & 0.0000 \\
\hline & 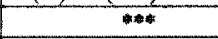 & N.D & & 0.0000 \\
\hline & $504(\mathrm{H}) \mathrm{C} 29(20 \mathrm{R})$ & N.D. & & 0.0000 \\
\hline & TOTAL & & & 0,0000 \\
\hline \multirow[t]{10}{*}{ IRI AROMATICS } & $026(20 \mathrm{~S})$ & ND. & & 0.0000 \\
\hline & $\mathrm{C} 26(20 \mathrm{R})+\mathrm{C} 27(20 \mathrm{~S})$ & N.D. & & 0.0000 \\
\hline & $C 28(20 S)$ & ND & & 0.0000 \\
\hline & $\mathrm{C} 27(20 \mathrm{R})$ & N.D & & 0,0000 \\
\hline & $\mathrm{C} 28(20 \mathrm{R})$ & N.D. & & 0.0000 \\
\hline & TOTAL & & & 0.0000 \\
\hline & & & & \\
\hline & \multicolumn{2}{|c|}{ - $5 \alpha(H) C 27(\mathrm{~S})+5 \beta(\mathrm{H}) \mathrm{C} 28(\mathrm{~S})$} & & \\
\hline & \multicolumn{3}{|c|}{ ** $5 \alpha \alpha(\mathrm{H}) \mathrm{C} 27(20 \mathrm{R})+5 \alpha \alpha(\mathrm{H}) \mathrm{C} 28(20 \mathrm{~S})+5 \beta(\mathrm{H}) \mathrm{C} 28(20 \mathrm{R})+5 \beta \mathrm{C} 29(20 \mathrm{~S})$} & \\
\hline & $* * *: 5 \alpha(T) C 28(20 R)+5$ & $29(20 \mathrm{R})$ & & \\
\hline
\end{tabular}




\begin{tabular}{|c|c|c|c|c|}
\hline & \multicolumn{3}{|c|}{ THERMODESORPTION OF POSDONIA SHALE AT $150 \mathrm{C}$} & \\
\hline & & B & & \\
\hline & \multicolumn{2}{|c|}{ Werght of sarrple $=3.0150 \mathrm{~g}$} & & \\
\hline & \multirow{2}{*}{\multicolumn{3}{|c|}{ Weight of IS. (squalane) $=9.50 \mathrm{hg}$}} & \\
\hline & & & & \\
\hline & Comp & PkAres & IS Pk Area & (un/g) \\
\hline \multirow{26}{*}{ ALKANES } & $\mathrm{ClO}$ & 12532094 & 4576673 & 8.63 \\
\hline & $\mathrm{C} \|$ & 11194092 & 4576673 & 7.71 \\
\hline & $\mathrm{Cl} 2$ & 6400241 & 4576673 & 4.41 \\
\hline & $\mathrm{Cl3}$ & 3308778 & 4576673 & 2.28 \\
\hline & $\mathrm{Cl} 4$ & 137717 & 4576673 & 0.948 \\
\hline & $\mathrm{Cl5}$ & 685788 & 4576673 & 0.472 \\
\hline & $\mathrm{Cl6}$ & N.D & & 0.0000 \\
\hline & $\mathrm{Cl1}$ & ND. & & 0.0000 \\
\hline & $\mathrm{C} 18$ & N.D. & & 0,0000 \\
\hline & PHY & ND. & & 0.0000 \\
\hline & C19 & N.D & & 0.0000 \\
\hline & $\mathrm{C} 20$ & ND. & & 0.0000 \\
\hline & $\mathrm{C} 21$ & ND & & 0.0000 \\
\hline & $\mathrm{C22}$ & N.D. & & 0.0000 \\
\hline & $\mathrm{C23}$ & N.D. & & 0,0000 \\
\hline & $\mathrm{C} 24$ & N.D. & & 0.0000 \\
\hline & $\mathrm{C25}$ & ND. & & 0.0000 \\
\hline & $\mathrm{C} 26$ & N.D. & & 0.0000 \\
\hline & $\mathrm{C} 27$ & ND. & & 0,0000 \\
\hline & $\mathrm{C} 28$ & ND. & & 0.0000 \\
\hline & $\mathrm{C} 29$ & ND. & & 0.0000 \\
\hline & $C 30$ & N.D. & & 0.0000 \\
\hline & $\mathrm{c} 31$ & ND & & 0.0000 \\
\hline & $\mathrm{C} 32$ & ND. & & 0.0000 \\
\hline & $\mathrm{C} 33$ & ND & & 0.0000 \\
\hline & TOTAL ALKANES & & & 24.44 \\
\hline \multirow{19}{*}{ NAPHTHALENES } & NAPFTHALENE & 3637617 & 4575673 & 2.50 \\
\hline & $\mathrm{C}-1 \mathrm{MN}$ & N.D. & & 0.0000 \\
\hline & $\mathrm{C} .2 \mathrm{MN}$ & ND. & & 0.0000 \\
\hline & TOTAL MN & & & 0.0000 \\
\hline & 1-E.2-EDMN & N.D. & & 0,0000 \\
\hline & 2,$6 ; 2,7 \mathrm{DMN}$ & N.D. & & 0.0000 \\
\hline & 1,$3 ; 1,7 \mathrm{DMN}$ & N.D. & & 0.0000 \\
\hline & $1,6 \mathrm{DNN}$ & ND. & & 00000 \\
\hline & $1,4,1,3 ; 1,5 \mathrm{DMN}$ & N.D. & & 0.0000 \\
\hline & $1,8 \mathrm{DMN}$ & ND. & & 0.0000 \\
\hline & TOTAL DMN & & & 0,0000 \\
\hline & $1,3,7 \mathrm{mN}$ & ND. & & 0.0000 \\
\hline & $1,3,6 \mathrm{nMN}$ & N.D. & & 0.0000 \\
\hline & $1,4,6,1,3,5 \mathrm{TMN}$ & N.D. & & 0.0000 \\
\hline & $2,3.6 \mathrm{TMN}$ & N.D & & 0.0000 \\
\hline & $1,2,7,1,6,7,1,2,61 \mathrm{MN}$ & N.D. & & 0.0000 \\
\hline & $1,2,5 \mathrm{TMN}$ & N.D. & & 0.0000 \\
\hline & TOTAL TMN & & & 0.0000 \\
\hline & IOTAL NAPHS & & & 2.50 \\
\hline \multirow{14}{*}{ PHENATHALENES } & PHENATHLENE & N.D. & & 00000 \\
\hline & $\begin{array}{l}\text { ANTHRASENE } \\
\end{array}$ & N.D & & 0.0000 \\
\hline & 3-MP & ND & & 0.0000 \\
\hline & $2-M P$ & N.D. & & 0.0000 \\
\hline & 2-MA & N.D. & & 0.0000 \\
\hline & 9.MP & ND. & & 0.0000 \\
\hline & $1-\mathrm{MP}$ & N.D. & & 0.0000 \\
\hline & 1-MP+1-MA & ND & & 0.0000 \\
\hline & 9MA & N.D. & & 0.0000 \\
\hline & TOTAL MP & N.D & & 0.0000 \\
\hline & TOTAL MP $+\mathrm{MA}$ & ND & & 0.0000 \\
\hline & TOTAL DMP & N.D & & 0.0000 \\
\hline & TOTAL DMP+DMA & ND. & & 0.0000 \\
\hline & TOTAL PHENAS & & & 0.0000 \\
\hline
\end{tabular}




\begin{tabular}{|c|c|c|c|c|}
\hline HOPANES & Comp & Plsareg & IS PkArea & (ua/r) \\
\hline & $\mathrm{C} 2 \phi \alpha \beta$ & N.D & & 0.0000 \\
\hline & $\mathrm{C} 29 \beta \alpha$ & N.D. & & 0.0000 \\
\hline & $\mathrm{C} 30 \times \beta$ & ND & & 0.0000 \\
\hline & C30Ba & N.D & & 0,0000 \\
\hline & $\mathrm{C} 31 \alpha \beta(\mathrm{S})$ & N.D & & 0.0000 \\
\hline & $\mathrm{C} 3 \log \beta(\mathrm{R})$ & ND & & 0.0000 \\
\hline & $\mathrm{C} 30 \mathrm{~B} \mathrm{~B}$ & ND & & 0.0000 \\
\hline & $\mathrm{C} 2 \alpha \beta(\mathrm{S})$ & N.D. & & 0.0000 \\
\hline & $\mathrm{C} 32 \alpha \beta(\mathrm{R})$ & ND & & 0.0000 \\
\hline & $\mathrm{c} 33 \alpha \beta(\mathrm{S})$ & ND & & 00000 \\
\hline & $\mathrm{C} 33 \alpha \beta(R)$ & ND & & 0.0000 \\
\hline & $\mathrm{C} 34 \alpha \beta(S)$ & N.D & & 0.0000 \\
\hline & $\mathrm{C} 34 \times \mathrm{P}(\mathrm{R})$ & N.D & & 0.0000 \\
\hline & C35ap(s) & N.D. & & 0.0000 \\
\hline & $\mathrm{C} 35 \alpha \beta(\mathrm{R})$ & ND. & & 0.0000 \\
\hline & TOTAL & & & 0.0000 \\
\hline & & & & \\
\hline \multirow[t]{8}{*}{ MONO AROMATTCS } & $5 \beta(\mathrm{H}) 27(20 \mathrm{~S})$ & ND & & 0.0000 \\
\hline & $5 \beta(\mathrm{H}) \mathrm{C} 27(20 \mathrm{R})$ & N.D. & & 0.0000 \\
\hline & * & ND & & 0.0000 \\
\hline & \#* & ND. & & 0.0000 \\
\hline & $5 a(H) C 29(20 S)$ & N.D. & & 0.0000 \\
\hline & $* * *$ & ND & & 0.0000 \\
\hline & $50(\mathrm{H}) \mathrm{C} 29(20 \mathrm{R})$ & N.D. & & 0.0000 \\
\hline & TOTAL & & & 0.0000 \\
\hline \multirow[t]{10}{*}{ TRIAROMATICS } & $\mathrm{C} 26(20 \mathrm{~S})$ & N.D. & & 0.0000 \\
\hline & $\mathrm{C} 26(20 \mathrm{R})+\mathrm{C} 27(20 \mathrm{~S})$ & ND. & & 0.0000 \\
\hline & $\mathrm{C28(205)}$ & N.D. & & 0.0000 \\
\hline & $\mathrm{C} 27(20 \mathrm{R})$ & N.D. & & 0.0000 \\
\hline & $\mathrm{C} 28(20 \mathrm{R})$ & ND & & 0.0000 \\
\hline & TOTAL & & & 0.0000 \\
\hline & & & & \\
\hline & \multicolumn{2}{|c|}{$* \quad 5 \alpha(\mathrm{H}) \mathrm{C} 27(\mathrm{~S})+5 \beta(\mathrm{H}) \mathrm{C} 28(\mathrm{~S})$} & & \\
\hline & \multicolumn{3}{|c|}{ **: $5 \alpha(\mathrm{H}) \mathrm{C} 27(20 \mathrm{R})+5 \alpha(\mathrm{H}) \mathrm{C28}(20 \mathrm{~S})+5 \beta(\mathrm{H}) \mathrm{C} 28(20 \mathrm{R})+5 \beta \mathrm{C} 29(20 \mathrm{~S})$} & \\
\hline & $4+40 \mathrm{ar}(\mathrm{H}) \mathrm{C} 28(20 \mathrm{R}) \mathrm{H}$ & $29(20 \mathrm{R})$ & & \\
\hline
\end{tabular}




\begin{tabular}{|c|c|c|c|c|}
\hline & \multicolumn{3}{|c|}{ THERMODESORPTION OF POSLONIA SHALE AT $250 C$} & \\
\hline & & B & & \\
\hline & \multicolumn{2}{|c|}{ Weight of sample=3.0150 } & & \\
\hline & \multicolumn{3}{|c|}{ Weight of IS. (squalane) $=9.50 \mathrm{ug}$} & \\
\hline & & & & \\
\hline & Comp & Pk Arem & IS Pk Area & (ug/g) \\
\hline \multirow[t]{26}{*}{ ALKANES } & $\mathrm{ClO}$ & 1092483 & 1718436 & 2.00 \\
\hline & $\mathrm{Cll}$ & 1073144 & 1718436 & 1.97 \\
\hline & $\mathrm{Cl2}$ & 5210319 & 1718436 & 9.55 \\
\hline & $\mathrm{Cl3}$ & 6100970 & 1718436 & 11.19 \\
\hline & $\mathrm{Cl} 4$ & 6087863 & 1718436 & 11.16 \\
\hline & $\mathrm{ClS}$ & 5650964 & 1718436 & 10.36 \\
\hline & C16 & 4711298 & 1718436 & 8.64 \\
\hline & $\mathrm{C} 17+\mathrm{PRI}$ & 6744681 & 1718436 & 12.37 \\
\hline & $\mathrm{Cls}$ & 2222541 & 1718436 & 4.08 \\
\hline & PHY & 678439 & 1718436 & 1.24 \\
\hline & $\mathrm{Cl9}$ & 1560609 & 1718436 & 2.86 \\
\hline & $\mathrm{C} 20$ & 857222 & 1718436 & 1.57 \\
\hline & $\mathrm{C} 21$ & N.D. & & 0.0000 \\
\hline & $\mathrm{C} 22$ & N.D. & & 0.0000 \\
\hline & $\mathrm{C} 23$ & $\mathrm{ND}$ & & 0.0000 \\
\hline & $\mathrm{C} 24$ & N.D. & & 0.0000 \\
\hline & $\mathrm{C} 25$ & N.D. & & 0.0000 \\
\hline & $\mathrm{C} 26$ & N.D. & & 0.0000 \\
\hline & $\mathrm{C27}$ & N.D. & & 0.0000 \\
\hline & $\mathrm{C} 28$ & N.D. & & 00000 \\
\hline & $\mathrm{C} 29$ & N.D. & & 0,0000 \\
\hline & $\mathrm{C} 30$ & N.D. & & 0.0000 \\
\hline & C31 & N.D. & & 0.0000 \\
\hline & $\mathrm{C} 32$ & N.D. & & 0.0000 \\
\hline & $\mathrm{C} 33$ & N.D. & & 0.0000 \\
\hline & TOTAL ALKANES & & & 76.99 \\
\hline \multirow[t]{19}{*}{ NAPHTHALENES } & NAPHTHALENE & 10279879 & 1718436 & 18.85 \\
\hline & $\mathrm{C}-1 \mathrm{MN}$ & 13284703 & 1718436 & 24.36 \\
\hline & $\mathrm{C}-2 \mathrm{MN}$ & 10541217 & 1718436 & 19.33 \\
\hline & TOTAL MN & & & 43.69 \\
\hline & 1-E,2-EDMN & 2373692 & 1718436 & 4.35 \\
\hline & 2,$6 ; 2,7 \mathrm{DMN}$ & 4103425 & 1718436 & 7.52 \\
\hline & $1,3: 1, \mathrm{TMM}$ & 4738488 & 1718436 & 8.69 \\
\hline & $1,6 \mathrm{DMN}$ & 4624410 & 1718436 & 8.48 \\
\hline & $1,4,1,3,1,5 \mathrm{DMN}$ & 3259510 & 1718436 & 5.98 \\
\hline & $1,8 \mathrm{DMN}$ & 1549753 & 1718436 & 2.84 \\
\hline & TOTAL DMN & & & 37.86 \\
\hline & $1,3.7 \mathrm{MN}$ & 1226223 & 1718436 & $2.25^{\circ}$ \\
\hline & $1,3,6 \mathrm{TMN}$ & 997678 & 1718436 & 1.83 \\
\hline & $1,4,6,1,3,5 \mathrm{MMN}$ & 800249 & 1718436 & 1.47 \\
\hline & $2,3,61 \mathrm{MN}$ & 472467 & 1718436 & 0.866 \\
\hline & $1,2,7,1,6,7,1,2,6 \mathrm{IMN}$ & 1294634 & 1718436 & 2.37 \\
\hline & $1,2,5 \mathrm{MMN}$ & 512240 & 1718436 & 0.939 \\
\hline & TOTAL IMN & & & 9.72 \\
\hline & TOTAL NAPHS & & & 110.12 \\
\hline \multirow[t]{14}{*}{ PHENATHALENES } & PHENATHLENE & 1656946 & 1718436 & 3.04 \\
\hline & ANIHRASENE & $\mathrm{ND}$ & & 0.0000 \\
\hline & 3-MP & 306924 & 1718436 & 0.563 \\
\hline & 2-MP & 310056 & 1718436 & 0.569 \\
\hline & $2-\mathrm{MA}$ & ND. & & 0,0000 \\
\hline & 9-MP & 340903 & 1718436 & 0.625 \\
\hline & 1-MP & 442973 & 1718436 & 0.812 \\
\hline & $1-M P+1-M A$ & ND & & 0.0000 \\
\hline & $9 \mathrm{MA}$ & N.D. & & 0.0000 \\
\hline & TOTAL $\mathrm{MP}$ & ND & & 2.57 \\
\hline & TOTAL MP+MA & ND & & 0.0000 \\
\hline & TOTAL DMP & N.D. & & 0.0000 \\
\hline & TOTAL DMP+DMA & ND. & & 0.0000 \\
\hline & TOTAL PHENAS & & & 5.61 \\
\hline
\end{tabular}




\begin{tabular}{|c|c|c|c|c|}
\hline HOPANES & Comp & Pk Ares & IS Pk Area & $(u \times / D)$ \\
\hline & $C 29 \alpha \beta$ & N.D & & 0.0000 \\
\hline & $C 29 \beta \alpha$ & N.D & & 0.0000 \\
\hline & $\mathrm{C} 30 \alpha \beta$ & N.D. & & 0.0000 \\
\hline & $\mathrm{C} 30 \beta \alpha$ & N.D. & & 0.0000 \\
\hline & $C 3 \mid \alpha \beta(S)$ & $\mathrm{ND}$ & & 0,0000 \\
\hline & $\mathrm{C} 3 / \alpha \beta(\mathrm{R})$ & ND. & & 0.0000 \\
\hline & $C 30 \beta \beta$ & ND & & 0,0000 \\
\hline & $C 32 \alpha \beta(S)$ & $\mathrm{ND}$ & & 0.0000 \\
\hline & $\mathrm{C} 32 \alpha \beta(\mathrm{R})$ & ND & & 0.0000 \\
\hline & $\mathrm{C} 33 \alpha \beta(\mathrm{S})$ & ND & & 0.0000 \\
\hline & $\mathrm{C} 33 \alpha \beta(\mathrm{R})$ & ND & & 00000 \\
\hline & $C 34 \alpha \beta(S)$ & N.D. & & 0.0000 \\
\hline & C34 $3 \beta(R)$ & ND & & 0.0000 \\
\hline & $C 35 \alpha \beta(S)$ & ND. & & 0.0000 \\
\hline & $\mathrm{C} 35 \propto \mathrm{B}(\mathrm{R})$ & ND. & & 0.0000 \\
\hline & TOTAL & & & 0.0000 \\
\hline \multirow[t]{8}{*}{ MONO AROMATICS } & $58(\mathrm{H}) \mathrm{C} 27(20 \mathrm{~S})$ & N.D. & & 00000 \\
\hline & $5 \beta(\mathrm{H}) \mathrm{C} 27(20 \mathrm{R})$ & N.D. & & 0.0000 \\
\hline & $*$ & N.D. & & 0.0000 \\
\hline & $* *$ & N.D. & & 0.0000 \\
\hline & $50(\mathrm{H}) \mathrm{C} 29(20 \mathrm{~S})$ & N.D. & & 0.0000 \\
\hline & 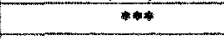 & ND. & & 0.0000 \\
\hline & $5 a(\mathrm{H}) \mathrm{C} 29(20 \mathrm{R})$ & ND & & 0,0000 \\
\hline & TOTAL & & & 0.0000 \\
\hline \multirow[t]{10}{*}{ IRIAROMATICS } & $C 26(20 \mathrm{~S})$ & N.D. & & 0.0000 \\
\hline & $\mathrm{C} 26(20 \mathrm{R})+\mathrm{C} 27(20 \mathrm{~S})$ & N.D. & & 0.0000 \\
\hline & C28(20S) & ND & & 0.0000 \\
\hline & $\mathrm{C} 27(20 \mathrm{R})$ & N.D. & & 0.0000 \\
\hline & $C 28(20 R)$ & N.D. & & 0.0000 \\
\hline & TOTAL & & & 0.0000 \\
\hline & & & & \\
\hline & \multicolumn{2}{|c|}{$\because \quad 5 \alpha(\mathrm{H}) \mathrm{C} 27(\mathrm{~S})+5 \beta(\mathrm{H}) \mathrm{C} 28(\mathrm{~S})$} & & \\
\hline & \multicolumn{3}{|c|}{ * $5 \alpha(\mathrm{H}) \mathrm{C} 27(20 \mathrm{R})+5 \alpha(\mathrm{H}) \mathrm{C} 28(20 \mathrm{~S})+5 \beta(\mathrm{H}) \mathrm{C} 28(20 \mathrm{R})+5 \beta \mathrm{C} 29(20 \mathrm{~S})$} & \\
\hline & $* * * .5 \alpha(\mathrm{H}) \mathrm{C} 28(20 \mathrm{R})+5$ & $9(20 \mathrm{R})$ & & \\
\hline
\end{tabular}




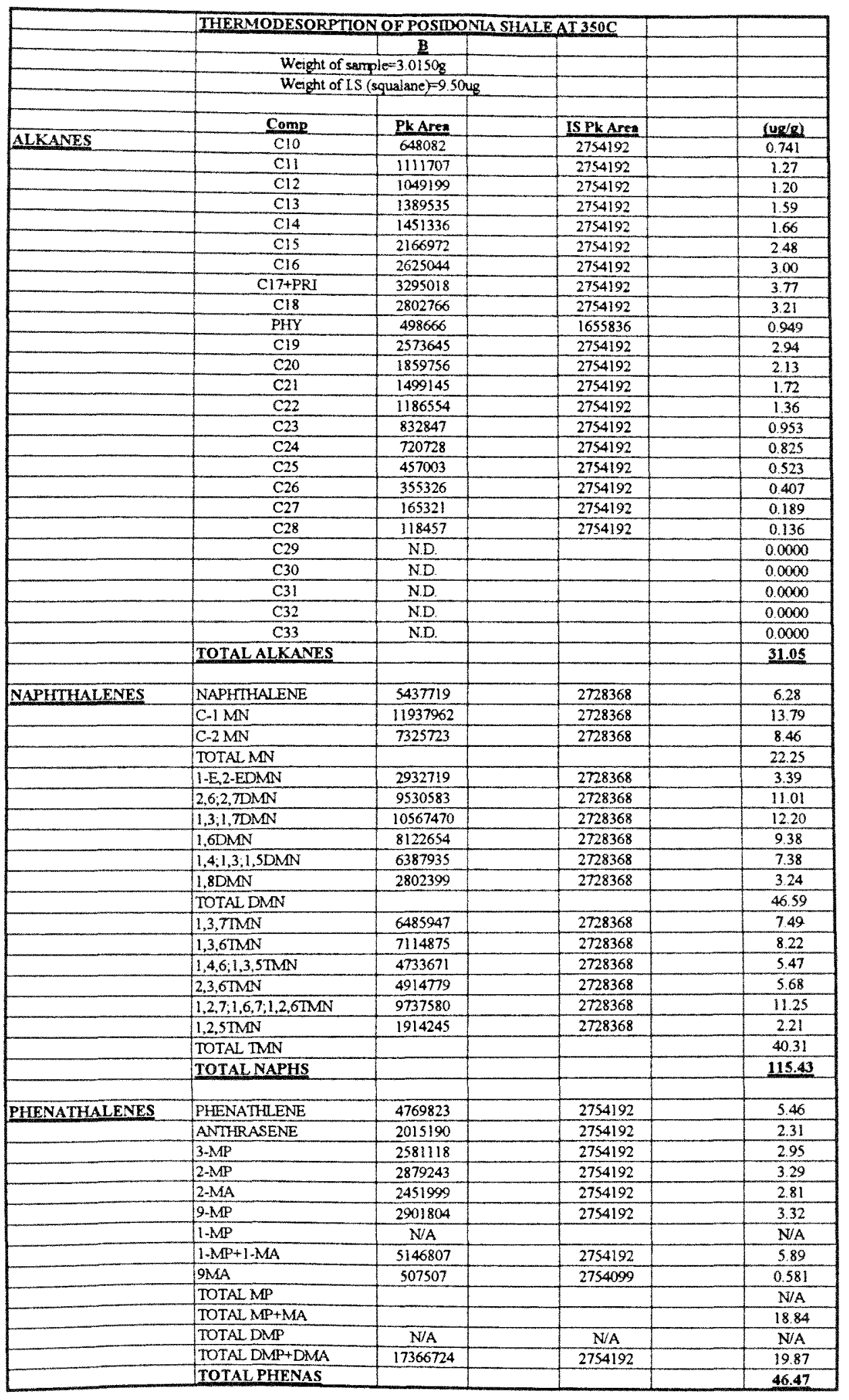




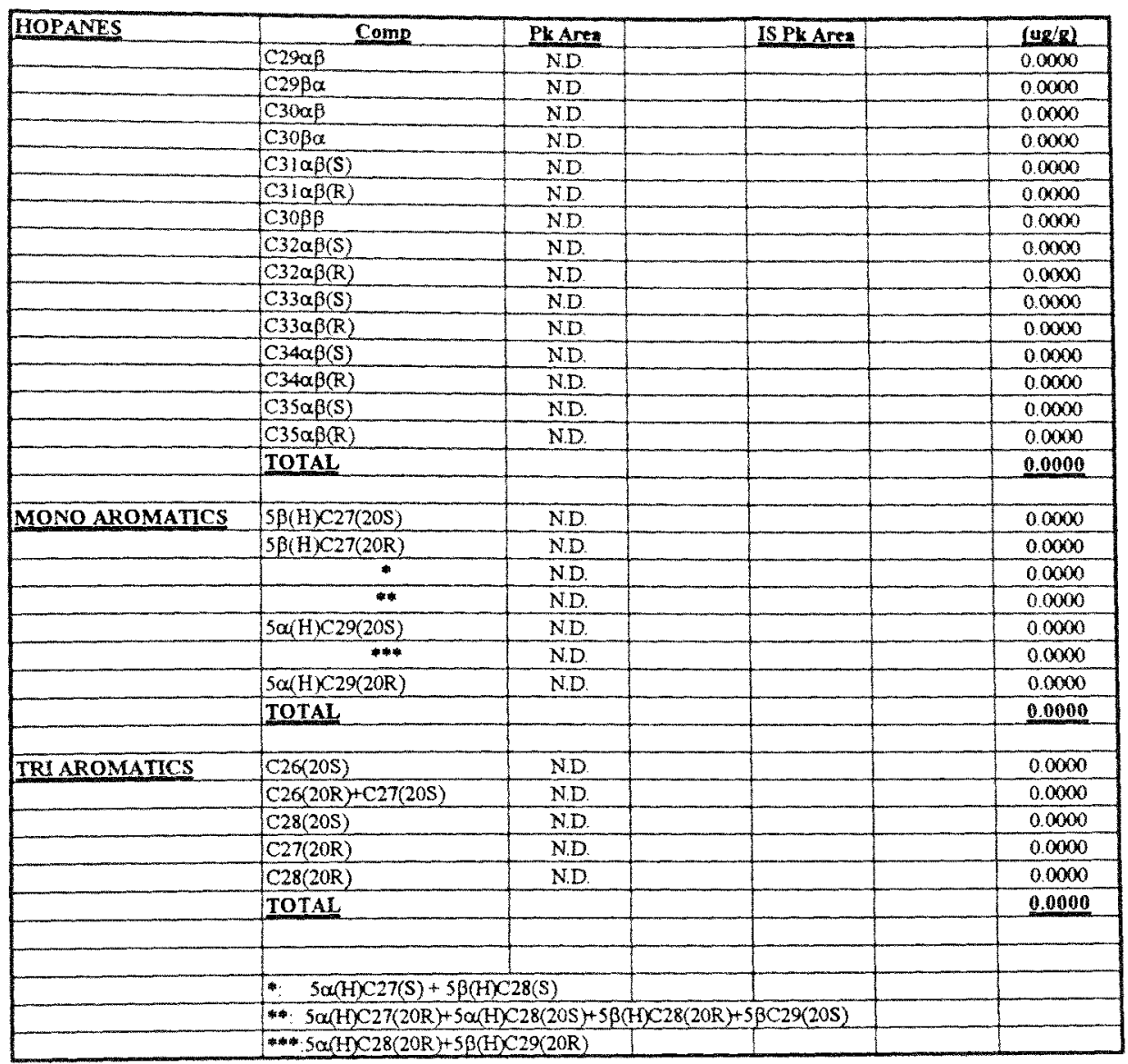




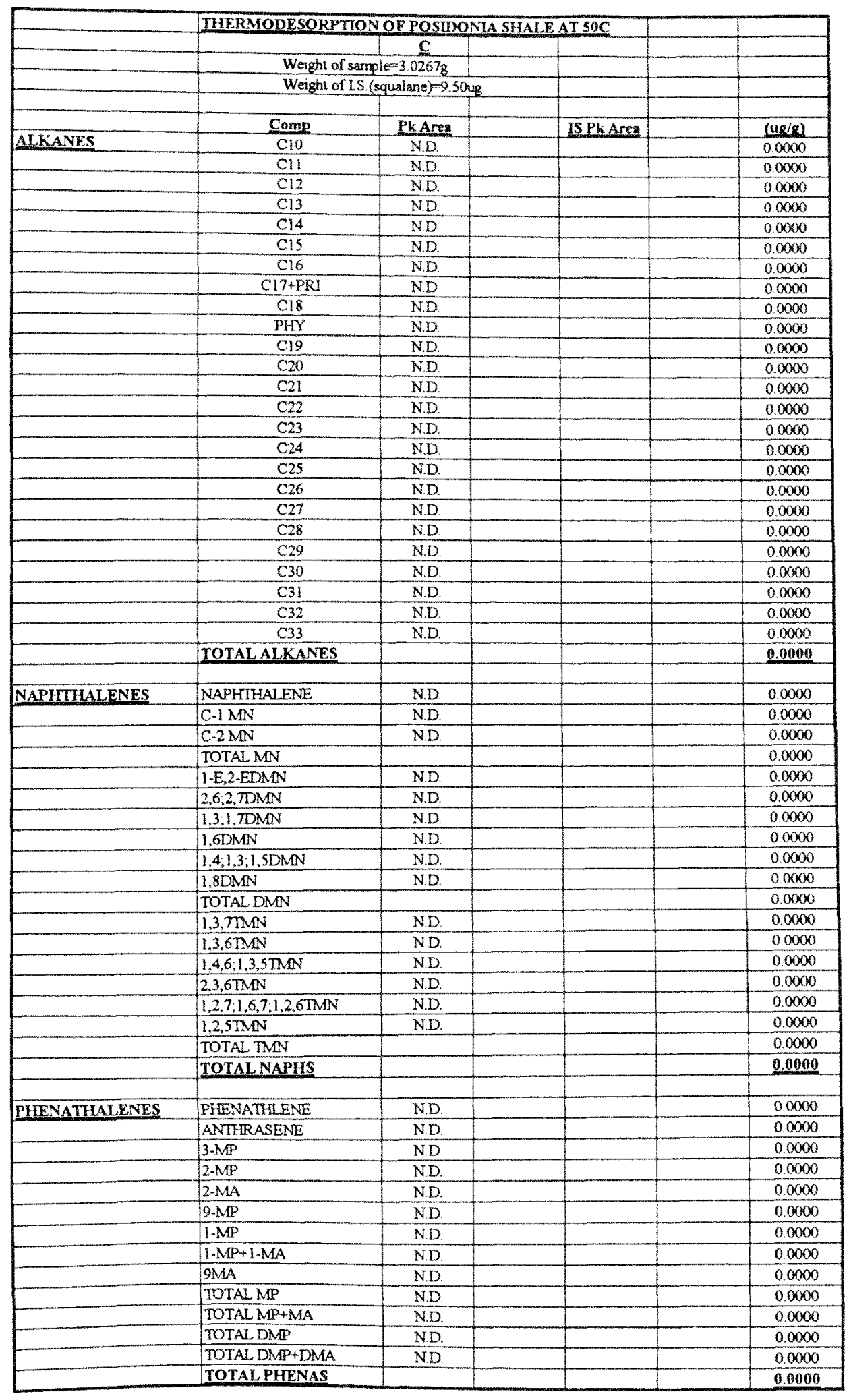




\begin{tabular}{|c|c|c|c|c|}
\hline HOPANES & Comp & PkArea & IS Pk Area & $(u \operatorname{sen}$ \\
\hline & $C 29 \alpha \beta$ & $\mathrm{ND}$ & & 0,0000 \\
\hline & $\mathrm{C} 29 \beta \alpha$ & N.D. & & 0.0000 \\
\hline & $\mathrm{C} 30 \alpha \beta$ & ND & & 0.0000 \\
\hline & $\mathrm{C30 \beta a}$ & N.D. & & 0.0000 \\
\hline & $c 31 \alpha \beta(S)$ & ND & & 00000 \\
\hline & $C 3 \mid \alpha \beta(R)$ & NO & & 0.0000 \\
\hline & cзope & ND & & 0.0000 \\
\hline & 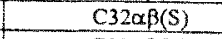 & ND & & 0.0000 \\
\hline & $\mathrm{C} 32 \alpha \beta(\mathrm{R})$ & ND & & 0.0000 \\
\hline & $c 33 \alpha 6(s)$ & N.D & & 0.0000 \\
\hline & $\mathrm{C3} 3 \alpha \beta(R)$ & N.D. & & 0,0000 \\
\hline & $C 34 \alpha p(s)$ & N.D. & & 00000 \\
\hline & $\mathrm{C} 34 \alpha \mathrm{Q}(\mathrm{R})$ & N.D. & & 0.0000 \\
\hline & $\mathrm{C} 35 \alpha \beta(\mathrm{S})$ & N.D & & 0.0000 \\
\hline & $\mathrm{C} 35 \alpha \beta(\mathrm{R})$ & ND. & & 0.0000 \\
\hline & TOTAL & & & 0.0000 \\
\hline & & & & \\
\hline \multirow[t]{8}{*}{ MONO ABOMATICS } & $58(\mathrm{H}) \mathrm{C} 27(20 \mathrm{~S})$ & ND. & & 0.0000 \\
\hline & $58(\mathrm{H}) \mathrm{C} 27(20 \mathrm{R})$ & N.D & & 0.0000 \\
\hline & 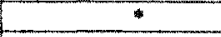 & ND. & & 0.0000 \\
\hline & $* *$ & ND. & & 0.0000 \\
\hline & $5 \alpha(\mathrm{H}) C 29(20 \mathrm{~S})$ & N.D. & & 0.0000 \\
\hline & $* * *$ & N.D. & & 0.0000 \\
\hline & $50(\mathrm{H}) \mathrm{C} 29(20 \mathrm{R})$ & N.D & & 0.0000 \\
\hline & TOTAL & & & 0.0000 \\
\hline \multirow[t]{10}{*}{ TRIAROMATICS } & C26(20S) & N.D. & & 0.0000 \\
\hline & $\mathrm{C} 26(20 \mathrm{R})+\mathrm{C} 27(20 \mathrm{~S})$ & N.D. & & 0,0000 \\
\hline & $\mathrm{C} 28(20 \mathrm{~S})$ & N.D. & & 0.0000 \\
\hline & $\mathrm{C} 27(20 \mathrm{R})$ & N.D. & & 0,0000 \\
\hline & $\mathrm{C} 28(20 \mathrm{R})$ & N.D. & & 0.0000 \\
\hline & TOTAL & & & 0.0000 \\
\hline & & & & \\
\hline & \multicolumn{2}{|c|}{ *: $\quad 5 \alpha(\mathrm{H}) \mathrm{C} 27(\mathrm{~S})+5 \beta(\mathrm{H}) \mathrm{C} 28(\mathrm{~S})$} & & \\
\hline & \multicolumn{3}{|c|}{ **: $5 \alpha(\mathrm{H}) \mathrm{C} 27(20 \mathrm{R})+5 \alpha(\mathrm{H}) \mathrm{C} 28(20 \mathrm{~S})+5 \beta(\mathrm{H}) \mathrm{C} 28(20 \mathrm{R})+5 \beta \mathrm{C} 29(20 \mathrm{~S})$} & \\
\hline & $* *+.50(\mathrm{H}) \subset 28(20 \mathrm{R})+5$ & $29(20 \mathrm{R})$ & & \\
\hline
\end{tabular}




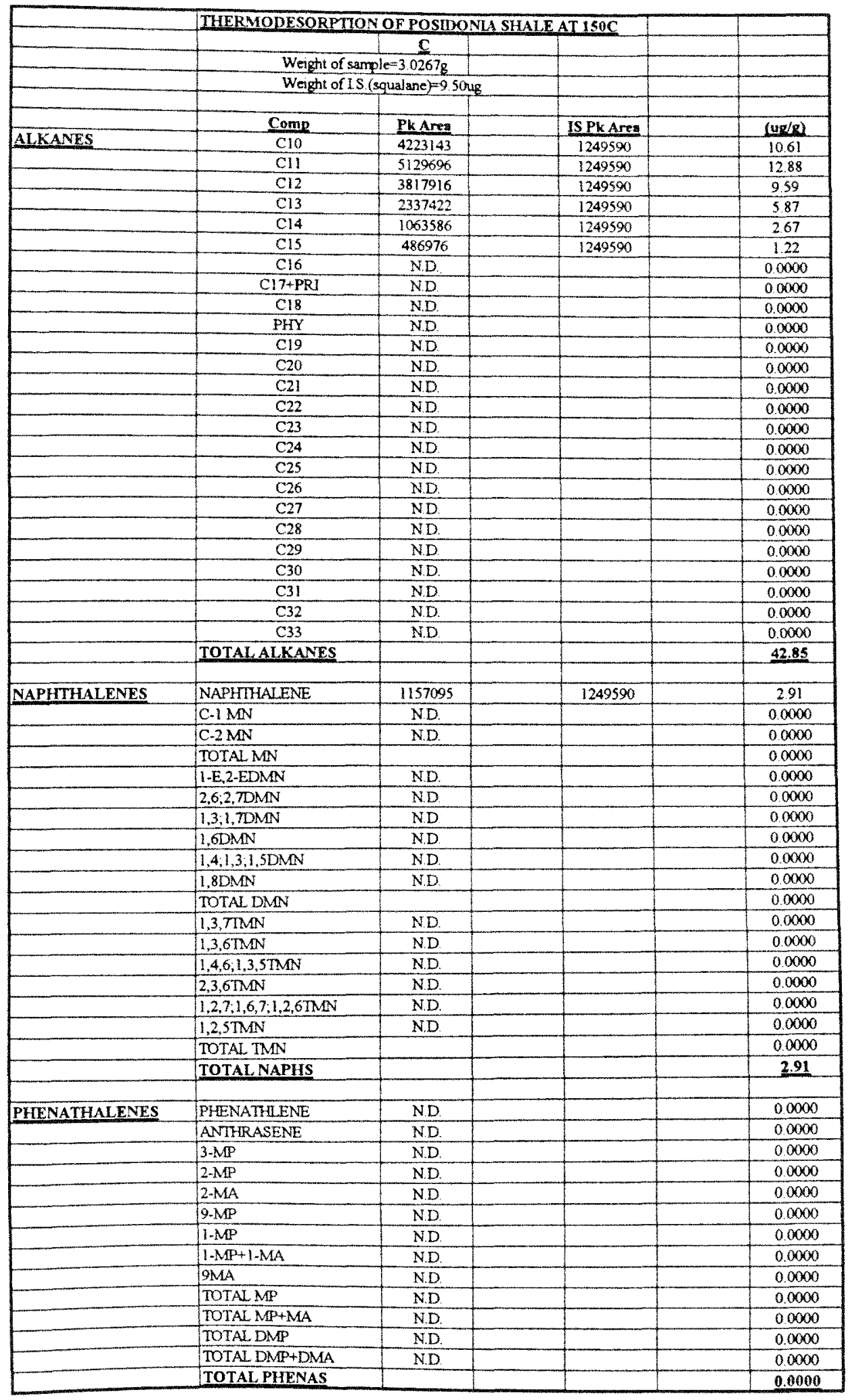




\begin{tabular}{|c|c|c|c|c|}
\hline HOPANES & Comp & PkArea & IS PK Are: & $(u g / g)$ \\
\hline & $\mathrm{C} 29 \alpha \beta$ & N.D. & & 00000 \\
\hline & C298a & N.D. & & 0.0000 \\
\hline & $\mathrm{C} 30 \mathrm{\alpha} \beta$ & N.D & & 00000 \\
\hline & $\mathrm{C} 30 \mathrm{~B} \alpha$ & ND. & & 0.0000 \\
\hline & $\mathrm{C} 31 \alpha \beta(S)$ & ND. & & 0.0000 \\
\hline & $\mathrm{C} 31 \alpha \beta(R)$ & N.D. & & 0.0000 \\
\hline & $C 30 \beta \beta$ & ND. & & 0.0000 \\
\hline & $\mathrm{C} 32 \alpha \beta(S)$ & ND & & 0.0000 \\
\hline & $C 32 \alpha \beta(R)$ & ND. & & 0.0000 \\
\hline & $\mathrm{C} 33 \alpha \beta(\mathrm{S})$ & ND & & 0.0000 \\
\hline & $\mathrm{C} 33 \alpha \beta(\mathrm{R})$ & ND. & & 0.0000 \\
\hline & $c 34 \alpha \beta(S)$ & N.D. & & 0.0000 \\
\hline & $\mathrm{C} 34 \alpha \beta(R)$ & N.D. & & 00000 \\
\hline & $\mathrm{C} 35 \alpha \beta(\mathrm{S})$ & N.D. & & 0.0000 \\
\hline & $\mathrm{C} 35 \alpha \beta(\mathrm{R})$ & N.D. & & 0.0000 \\
\hline & TOTAL & & & 0.0000 \\
\hline \multirow{8}{*}{ MONO AROMATICS } & $5 \beta(\mathrm{H}) C 27(20 \mathrm{~S})$ & N.D. & & 00000 \\
\hline & $\frac{5 \beta(\mathrm{H}) C 27(20 \mathrm{~S})}{5 \beta(\mathrm{H}) \mathrm{C} 27(20 \mathrm{R})}$ & N.D. & & $\frac{0.0000}{0.0000}$ \\
\hline & $*$ & N.D. & & 00000 \\
\hline & + & N.D. & & 0.0000 \\
\hline & $504(\mathrm{H}) \mathrm{C} 29(20 \mathrm{~S})$ & N. & & 0.0000 \\
\hline & $+\cdots$ & N.D & & 0.0000 \\
\hline & $5 \alpha(\mathrm{H}) \mathrm{C} 29(20 \mathrm{R})$ & N.D. & & 0,0000 \\
\hline & TOTAL & & & 0.0000 \\
\hline \multirow[t]{11}{*}{ TRI AROMATICS } & $\mathrm{C26(20S)}$ & N.D & & 0.0000 \\
\hline & $C 26(20 R)+C 27(20 S)$ & N.D. & & 0.0000 \\
\hline & $\mathrm{C} 28(20 \mathrm{~S})$ & N.D. & & 0,0000 \\
\hline & $\mathrm{C} 27(20 \mathrm{R})$ & ND. & & 0.0000 \\
\hline & $\mathrm{C} 28(20 \mathrm{R})$ & ND. & & 0.0000 \\
\hline & TOTAL & & & 0.0000 \\
\hline & & & & \\
\hline & & & & \\
\hline & \multicolumn{2}{|c|}{ * $\quad 5 \alpha(\mathrm{H}) \mathrm{C} 27(\mathrm{~S})+5 \beta(\mathrm{HNC} 28(\mathrm{~S})$} & & \\
\hline & \multicolumn{3}{|c|}{ **: $5 \alpha(H) C 27(20 R)+5 \alpha(\mathrm{HXC} 28(20 \mathrm{~S})+5 \beta(\mathrm{H}) \mathrm{C} 28(20 \mathrm{R})+5 \beta \mathrm{C} 29(20 \mathrm{~S})$} & \\
\hline & $* * 5 \mathrm{ar}(\mathrm{H}) \mathrm{C} 28(20 \mathrm{R})$ & $29(20 \mathrm{R})$ & & \\
\hline
\end{tabular}




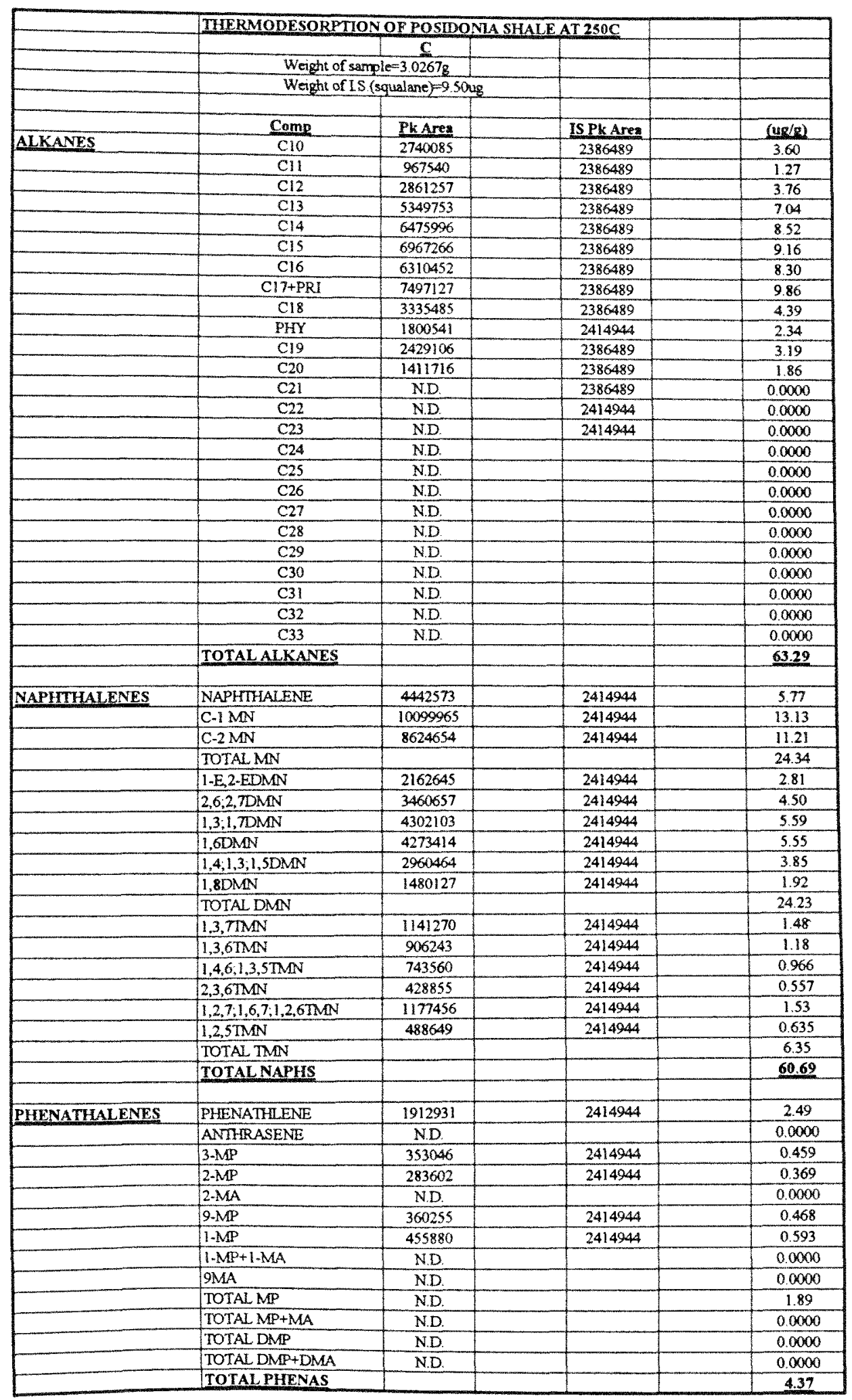




\begin{tabular}{|c|c|c|c|c|}
\hline \multirow[t]{17}{*}{ HOPANES } & Cornp & PkArex & IS PKAre & $(u g / p)$ \\
\hline & $\mathrm{C} 29 \times 8$ & N.D. & & 0.0000 \\
\hline & $\mathrm{C} 29 \beta \alpha$ & ND. & & 0,0000 \\
\hline & $\mathrm{C} 30 \alpha \beta$ & ND & & 0.0000 \\
\hline & $C 30 \beta \alpha$ & ND & & 0,0000 \\
\hline & $C 31 \alpha \beta(S)$ & ND & & 0,0000 \\
\hline & $\mathrm{C} 31 \alpha \beta(\mathrm{R})$ & N.D & & 0.0000 \\
\hline & $\operatorname{cop} \beta$ & N.D & & 0.0000 \\
\hline & $\mathrm{C} 32 \alpha \beta(\mathrm{S})$ & ND. & & 0,0000 \\
\hline & $C 32 \alpha \beta(R)$ & N.D & & 0.0000 \\
\hline & $\mathrm{C} 33 \alpha \beta(\mathrm{S})$ & $\mathrm{ND}$ & & 0.0000 \\
\hline & $\mathrm{C} 33 \alpha \beta(\mathrm{R})$ & N.D & & 0.0000 \\
\hline & $C 34 \alpha \beta(s)$ & N.D & & 0.0000 \\
\hline & $\mathrm{C} 34 \alpha \beta(\mathrm{R})$ & N.D. & & 0.0000 \\
\hline & $\mathrm{C} 35 \alpha \beta(\mathrm{S})$ & ND. & & 0,0000 \\
\hline & $\mathrm{C} 35 \alpha \beta(\mathrm{R})$ & N.D. & & 0.0000 \\
\hline & TOTAL & & & 0.0000 \\
\hline \multirow[t]{8}{*}{ MONO AROMATICS } & $5 \beta(\mathrm{H}) \mathrm{C2} 2(20 \mathrm{~S})$ & N.D. & & 0.0000 \\
\hline & $5 \beta(\mathrm{H}) \mathrm{C27}(20 \mathrm{R})$ & N.D. & & 0,0000 \\
\hline & 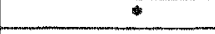 & N.D. & & 0,0000 \\
\hline & * & N.D. & & 0.0000 \\
\hline & $5 \alpha(\mathrm{H}) \mathrm{C} 29(20 \mathrm{~S})$ & N.D. & & 0,0000 \\
\hline & $+\%$ & ND & & 0.0000 \\
\hline & $5 \alpha(\mathrm{H}) C 29(20 \mathrm{R})$ & N.D. & & 0.0000 \\
\hline & TOTAL & & & 0.0000 \\
\hline \multirow[t]{10}{*}{ TRI AROMATICS } & $(26205)$ & N.D. & & 0.0000 \\
\hline & $\mathrm{C} 26(20 \mathrm{R})+\mathrm{C} 27(2 \mathrm{OS})$ & N.D. & & 0,0000 \\
\hline & $\mathrm{C} 28(20 \mathrm{~S})$ & N.D. & & 0.0000 \\
\hline & $\mathrm{C} 27(20 \mathrm{R})$ & N.D. & & 0.0000 \\
\hline & $\mathrm{C28}(20 \mathrm{R})$ & N.D. & & 0,0000 \\
\hline & TOTAL & & & 0.0000 \\
\hline & & & & \\
\hline & \multicolumn{2}{|c|}{ : $\quad 5 \alpha(\mathrm{H} \times 27 \mathrm{~S})+5 \beta(\mathrm{HCC} 28(\mathrm{~S})$} & & \\
\hline & \multicolumn{3}{|c|}{ **: $5 \alpha(\mathrm{H}) \mathrm{C} 27(20 \mathrm{R})+5 \alpha(\mathrm{H}) \mathrm{C} 28(20 \mathrm{~S})+5 \beta(H) 228(20 \mathrm{R})+5 \beta \mathrm{C} 29(20 \mathrm{~S})$} & \\
\hline & \multicolumn{2}{|c|}{ 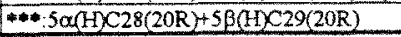 } & & \\
\hline
\end{tabular}




\begin{tabular}{|c|c|c|c|c|}
\hline & \multicolumn{3}{|c|}{ THERMODESOFPTION OF POSWONL SHALE AT $350 \mathrm{C}$} & \\
\hline & & $\mathrm{C}$ & & \\
\hline & \multicolumn{2}{|c|}{ Weight of sample $=3.0267 \mathrm{~g}$} & & \\
\hline & \multicolumn{3}{|c|}{ Weight of LS (squalane) $=9.5048$} & \\
\hline & & & & \\
\hline & Comp & PkArea & IS Pk Area & (ura/g) \\
\hline \multirow[t]{26}{*}{ ALKANES } & $\mathrm{Cl0}$ & 323685 & 1015295 & 1.00 \\
\hline & $\mathrm{CII}$ & 395596 & 1015295 & 1.22 \\
\hline & $\mathrm{Cl} 2$ & 330798 & 1015295 & 102 \\
\hline & $\mathrm{C} 13$ & 236666 & 1015295 & 0.732 \\
\hline & $\mathrm{C} 14$ & 300202 & 1015295 & 0.928 \\
\hline & $\mathrm{C} 15$ & 339662 & 1015295 & 1.05 \\
\hline & $\mathrm{Cl}$ & 472149 & 1015295 & 1.46 \\
\hline & $\mathrm{Cl}+\mathrm{PRI}$ & 761089 & 1015295 & 2.35 \\
\hline & $\mathrm{Cl} 8$ & 867884 & 1015295 & 2.68 \\
\hline & PHY & 127203 & 1015295 & 0.393 \\
\hline & $\mathrm{C} 19$ & 545524 & 1015295 & 1.69 \\
\hline & $\mathrm{C} 20$ & 462160 & 1015295 & 1.43 \\
\hline & $\mathrm{C} 21$ & 372830 & 1015295 & 1.15 \\
\hline & $\mathrm{C} 22$ & 285511 & 1015295 & 0.883 \\
\hline & $\mathrm{C} 23$ & 268122 & 1015295 & 0.829 \\
\hline & $\mathrm{C} 24$ & 146112 & 1015295 & 0.452 \\
\hline & $C 25$ & 457003 & 1015295 & 1.41 \\
\hline & C26 & 108418 & 1015295 & 0.335 \\
\hline & 027 & 49107 & 1015295 & 0.152 \\
\hline & $\mathrm{C} 28$ & 23214 & 1015295 & 0.072 \\
\hline & $\mathrm{C} 29$ & 10948 & 1015295 & 0.034 \\
\hline & $\mathrm{C} 30$ & N.D. & & 0.0000 \\
\hline & C31 & ND & & 0.0000 \\
\hline & $\mathrm{C} 32$ & N.D. & & 0.0000 \\
\hline & $\mathrm{C} 33$ & N.D & & 0.0000 \\
\hline & TOTALALKANES & & & 21.28 \\
\hline \multirow[t]{19}{*}{ NAPHTHLALENES } & NAPHTHALENE & 1330838 & 1015295 & 4.11 \\
\hline & $\mathrm{C}-1 \mathrm{MN}$ & 2744087 & 1015295 & 8.48 \\
\hline & $\mathrm{C}-2 \mathrm{MN}$ & 1564641 & 1015295 & 4.84 \\
\hline & TOTAL MN & & & 13.32 \\
\hline & 1-E,2-EDMN & $\pi 7038$ & 1015295 & 2.40 \\
\hline & 2,$6 ; 2,7 \mathrm{DMN}$ & 2531277 & 1015295 & 7.83 \\
\hline & $1,3,1,7 \mathrm{DMN}$ & 2732298 & 1015295 & 8.45 \\
\hline & $1,6 \mathrm{DMN}$ & 2588570 & 1015295 & 8.00 \\
\hline & 1,$4 ; 1,3,1,5 \mathrm{DMN}$ & 1907124 & 1015295 & 5.90 \\
\hline & $1.80 \mathrm{DN}$ & 874760 & 1015295 & 2.70 \\
\hline & TOTAL DMN & & & 35.28 \\
\hline & $1,3,7 \mathrm{MN}$ & 1880853 & 1015295 & 5.81 \\
\hline & $1,3,6 \mathrm{MN}$ & 2400332 & 1015295 & 7.42 \\
\hline & $1,4,6,1,3,5 \mathrm{MMN}$ & 1687396 & 1015295 & 5.22 \\
\hline & $2,3,6 \mathrm{MMN}$ & 1585780 & 1015295 & 4,90 \\
\hline & $1,2,7,1,6,7,1,2,6 \mathrm{nMN}$ & 3397303 & 1015295 & 10.50 \\
\hline & $1,2,5 \mathrm{nMN}$ & 915464 & 1015295 & 2.83 \\
\hline & TOTAL $\mathrm{TMN}$ & & & 36.69 \\
\hline & TOTAL NAPHS & & & 89.40 \\
\hline \multirow[t]{14}{*}{ PHENATHALENES } & PHENATTLENE & 1604225 & 1015295 & 496 \\
\hline & ANTHRASENE & 930787 & 1015295 & 2.88 \\
\hline & 3-MP & 971029 & 1015295 & 3.00 \\
\hline & $2-M P$ & 1208665 & 1015295 & 3.74 \\
\hline & 2-MA & 591495 & 1015295 & 1.83 \\
\hline & 9-MP & 1404719 & 1015295 & 434 \\
\hline & (1-MP & $\mathrm{N} / \mathrm{A}$ & & $\mathrm{N} / \mathrm{A}$ \\
\hline & 1-MP+1-MA & 2991694 & 1015295 & 9.25 \\
\hline & $9 \mathrm{MA}$ & 386696 & 1015295 & 1,20 \\
\hline & TOTAL MP & & & N/A \\
\hline & TOTAL MP+MA & & & 23.35 \\
\hline & TOTAL DMP & $\mathrm{N} / \mathrm{A}$ & N/A & N/A \\
\hline & TOTAL DMP+DMA & 6366767 & 1015295 & 19.68 \\
\hline & TOTALPHENAS & & 1015295 & 50.87 \\
\hline
\end{tabular}




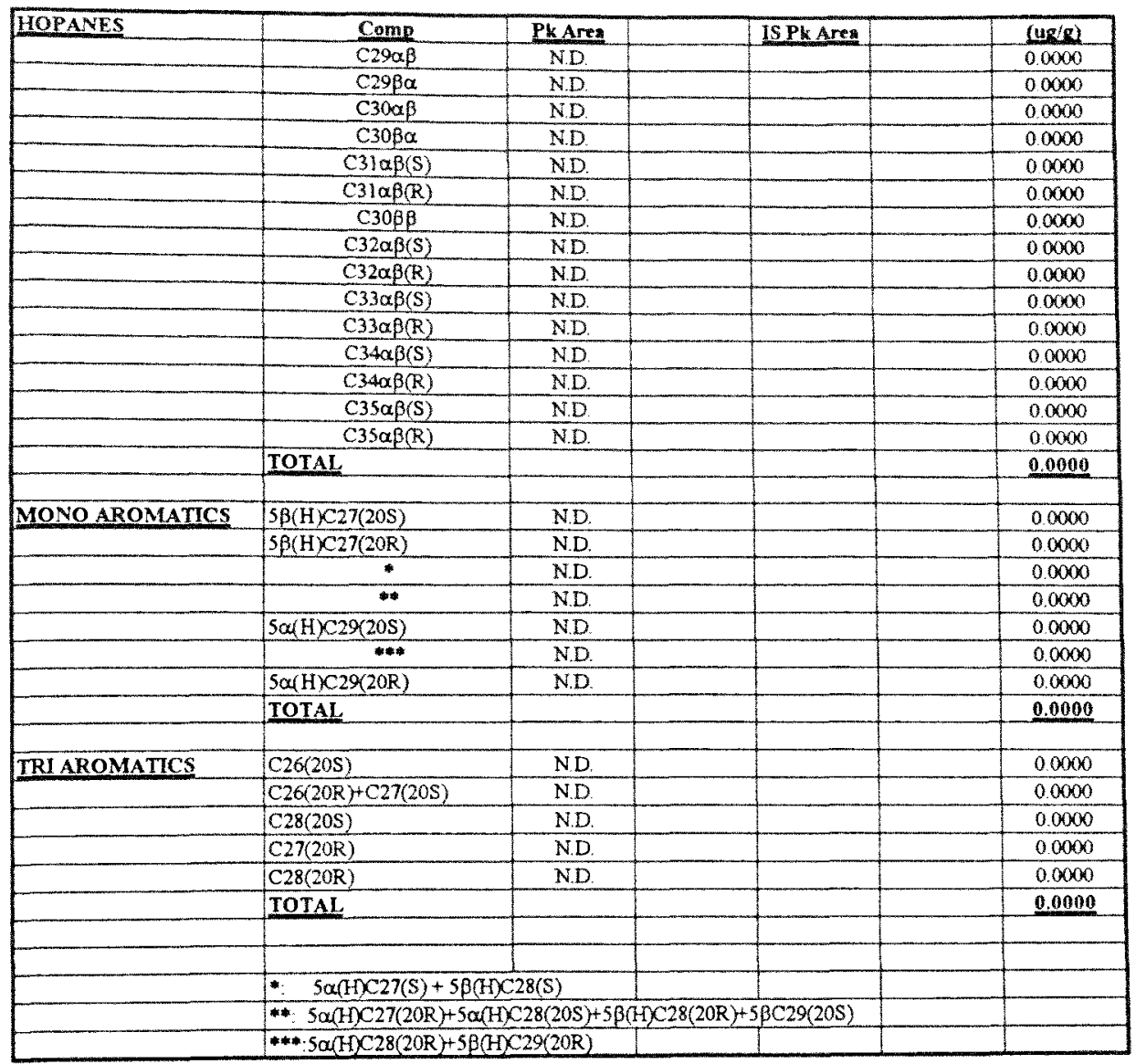




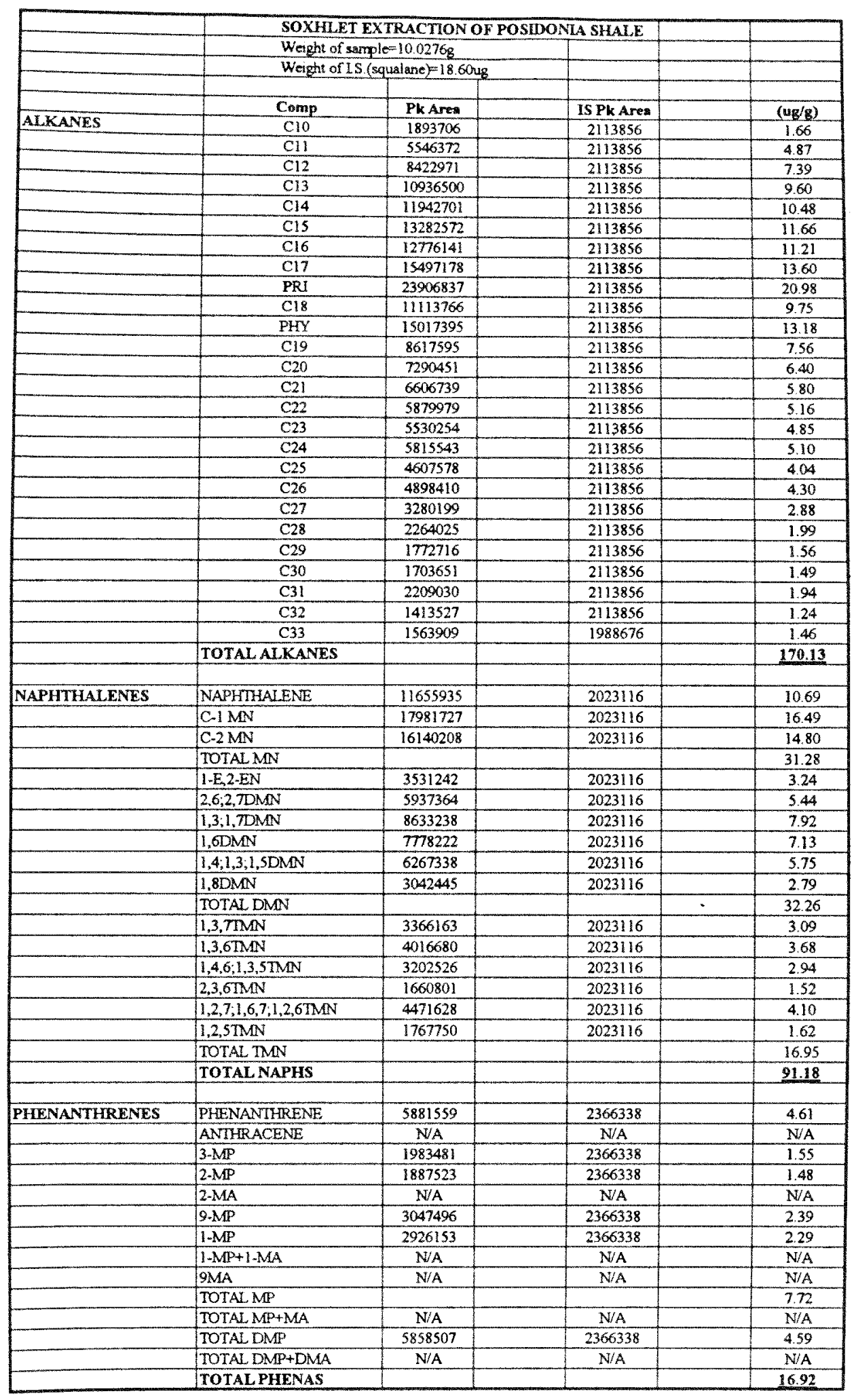




\begin{tabular}{|c|c|c|c|c|}
\hline & Comp & Pk Aren & IS Pk Area & $(u g / g)$ \\
\hline \multirow[t]{16}{*}{ HOPANES } & $c 29 \alpha \beta$ & 1233878 & 2234852 & 1.02 \\
\hline & $C_{29 \beta} \alpha$ & 285997 & 2234852 & 0.237 \\
\hline & $\mathrm{C} 30 \mathrm{\alpha} \beta$ & 2102319 & 2234852 & 1.74 \\
\hline & $C 30 \beta a$ & 470254 & 2234852 & 0.390 \\
\hline & $\mathrm{C} 31 \alpha \beta(\mathrm{S})$ & 834260 & 2234852 & 0.692 \\
\hline & $C 3 \operatorname{lo} \beta(R)$ & 641835 & 2234852 & 0.533 \\
\hline & $\mathrm{C} 30 \beta \mathrm{B}$ & N/A & 2234852 & 0.0000 \\
\hline & $C 32 \alpha \beta(S)$ & 520494 & 2234852 & 0.432 \\
\hline & $\mathrm{C} 32 \alpha \beta(\mathrm{R})$ & 483643 & 2234852 & 0.401 \\
\hline & $C 33 \alpha \beta(S)$ & 772797 & 2234852 & 0.641 \\
\hline & $C 33 \alpha \beta(R)$ & 794450 & 2234852 & 0.659 \\
\hline & $C 34 \alpha \beta(S)$ & 476232 & 2234852 & 0.395 \\
\hline & C34 $\alpha \beta(R)$ & 512409 & 2234852 & 0.425 \\
\hline & $C 35 \alpha \beta(S)$ & 444526 & 2234852 & 0.369 \\
\hline & $\mathrm{C} 35 \alpha \beta(\mathrm{R})$ & 411090 & 2234852 & 0.341 \\
\hline & TOTAL & & & 8.29 \\
\hline \multirow[t]{9}{*}{ MONO AROMATICS } & $5 \beta(H) C 27(20 S)$ & 1018907 & 2366338 & 0.799 \\
\hline & $5 \beta(\mathrm{H}) \mathrm{C} 27(20 \mathrm{R})$ & 1345568 & 2366338 & 1.05 \\
\hline & * & 3649389 & 2366338 & 2.86 \\
\hline & $*$ & 7136693 & 2366338 & 5.59 \\
\hline & $5 \alpha(\mathrm{H}) \mathrm{C} 29(20 \mathrm{~S})$ & 2418796 & 2366338 & 1.90 \\
\hline & $* * *$ & 3763003 & 2366338 & 2.95 \\
\hline & $50(\mathrm{H}) C 29(20 \mathrm{R})$ & 1216935 & 2366338 & 0.954 \\
\hline & TOTAL & & & 16.11 \\
\hline & & & & \\
\hline \multirow{11}{*}{ TRI AROMATICS } & $C 26(20 S)$ & 2718441 & 2366338 & 2.13 \\
\hline & $C 26(20 R)+C 27(20 S)$ & 6617737 & 2366338 & 5.19 \\
\hline & $C 28(20 S)$ & 4543700 & 2366338 & 3.56 \\
\hline & $\mathrm{C} 27(20 \mathrm{R})$ & 3838179 & 2366338 & 3.01 \\
\hline & $\mathrm{C} 28(20 \mathrm{R})$ & 5500734 & 2366338 & 4.31 \\
\hline & TOTAL & & & 18.20 \\
\hline & & & & \\
\hline & & & & \\
\hline & *: $\quad 5 \alpha(\mathrm{H}) \mathrm{C} 27(\mathrm{~S})+5$ & $8(\mathbf{S})$ & & \\
\hline & $*$ *: $5 \alpha(\mathrm{H}) \mathrm{C} 27(20 \mathrm{R})+5$ & $8(20 s)+50$ & C29(20R) & \\
\hline & $* * 5 \alpha(\mathrm{H}) 28(20 \mathrm{R})+5$ & $9(20 R)$ & & \\
\hline
\end{tabular}




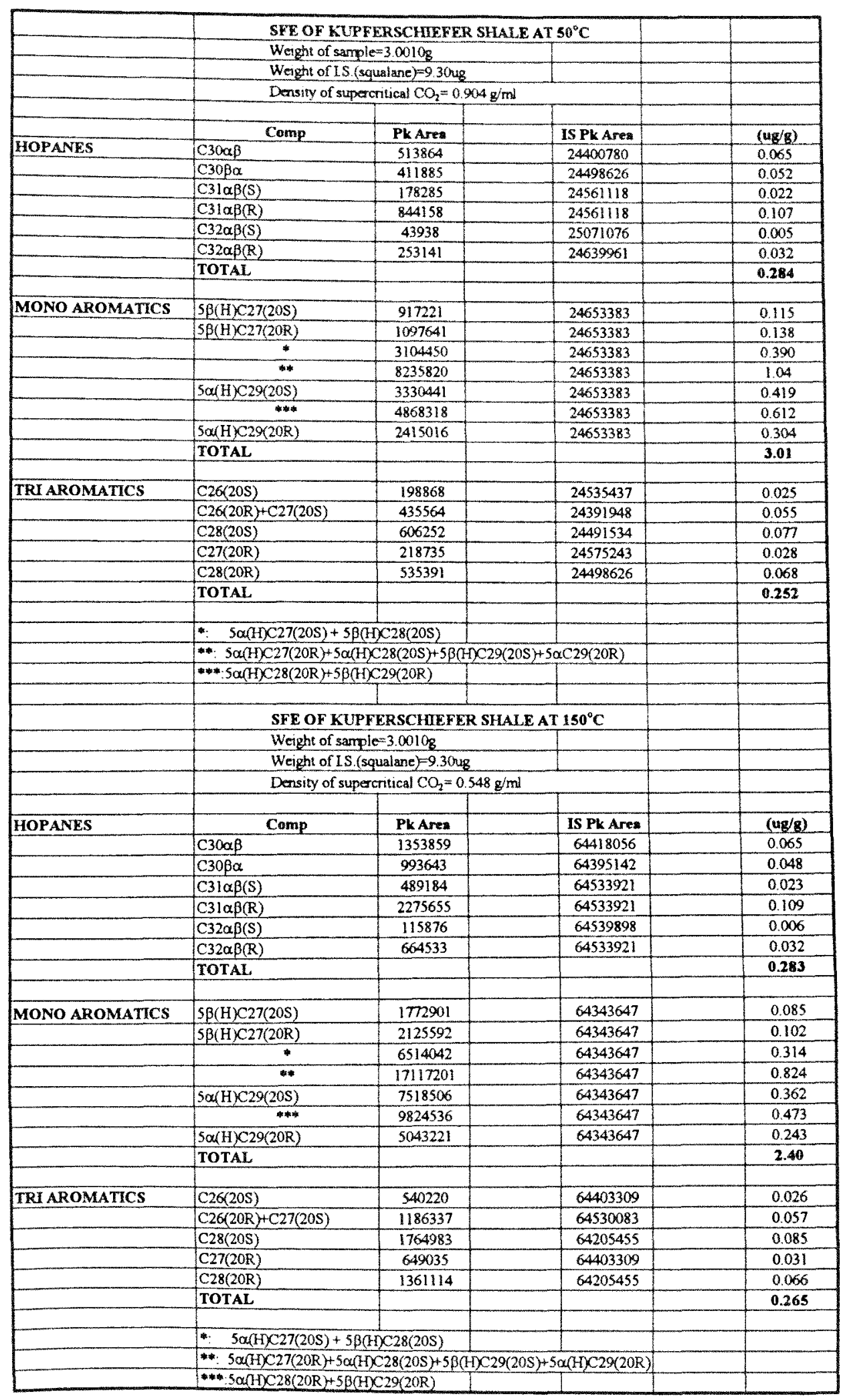




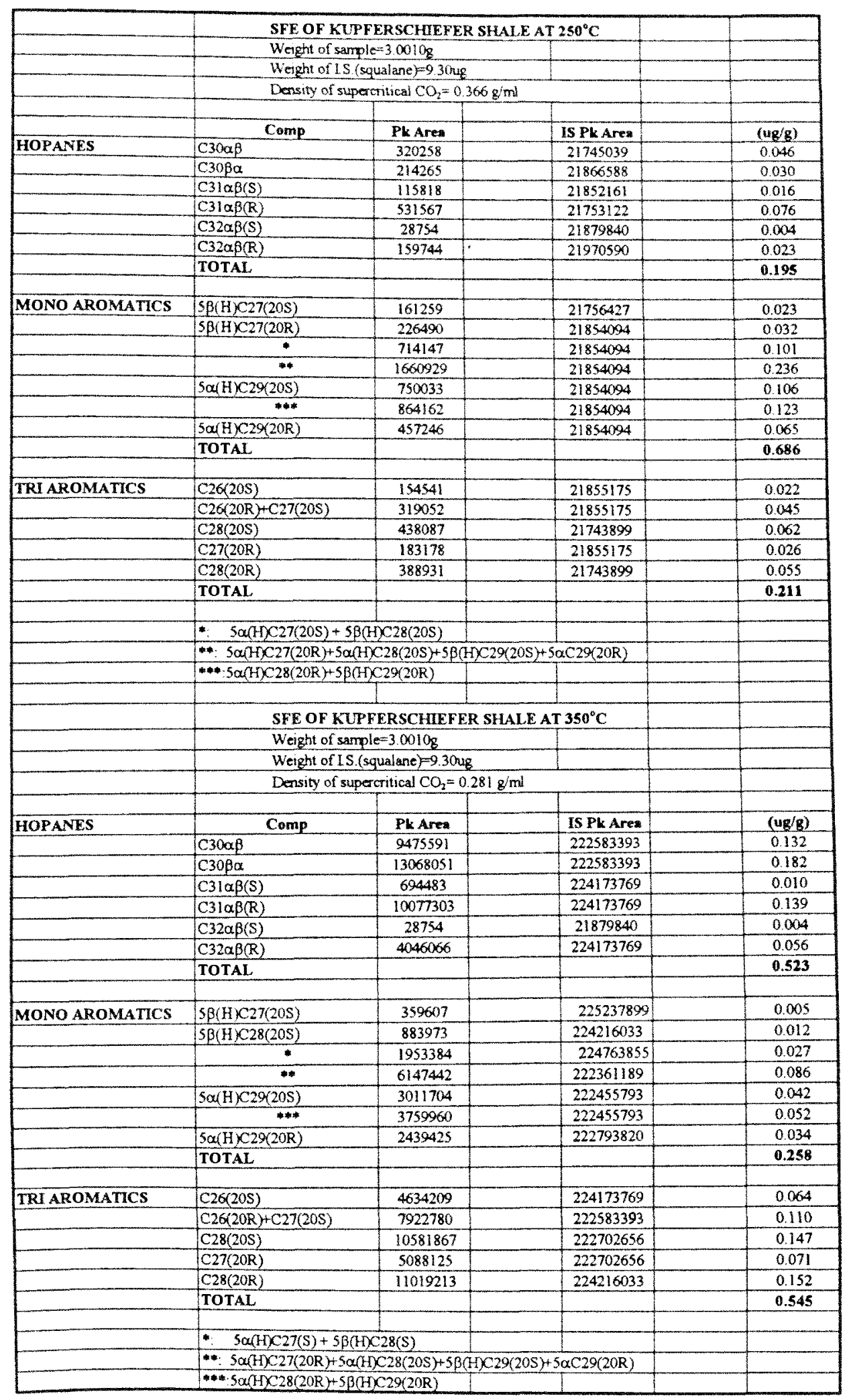

